\title{
Regionalisatie en financiering van de Engelse, Zweedse en Nederlandse gezondheidszorg
}

Citation for published version (APA):

Schrijvers, G. (1980). Regionalisatie en financiering van de Engelse, Zweedse en Nederlandse gezondheidszorg. [Doctoral Thesis, Maastricht University]. De Tijdstroom. https://doi.org/10.26481/dis.19800321gs

Document status and date:

Published: 01/01/1980

DOI:

10.26481/dis.19800321gs

Document Version:

Publisher's PDF, also known as Version of record

\section{Please check the document version of this publication:}

- A submitted manuscript is the version of the article upon submission and before peer-review. There can be important differences between the submitted version and the official published version of record.

People interested in the research are advised to contact the author for the final version of the publication, or visit the DOI to the publisher's website.

- The final author version and the galley proof are versions of the publication after peer review.

- The final published version features the final layout of the paper including the volume, issue and page numbers.

Link to publication

\footnotetext{
General rights rights.

- You may freely distribute the URL identifying the publication in the public portal. please follow below link for the End User Agreement:

www.umlib.nl/taverne-license

Take down policy

If you believe that this document breaches copyright please contact us at:

repository@maastrichtuniversity.nl

providing details and we will investigate your claim.
}

Copyright and moral rights for the publications made accessible in the public portal are retained by the authors and/or other copyright owners and it is a condition of accessing publications that users recognise and abide by the legal requirements associated with these

- Users may download and print one copy of any publication from the public portal for the purpose of private study or research.

- You may not further distribute the material or use it for any profit-making activity or commercial gain

If the publication is distributed under the terms of Article $25 \mathrm{fa}$ of the Dutch Copyright Act, indicated by the "Taverne" license above, 
REGIONALISATIE EN FINANCIERING VAN DE ENGELSE, ZWEEDSE EN NEDERLANDSE GEZONDHEIDSZORG 



\section{REGIONALISATIE EN FINANCIERING ${ }^{\circ 9}$ VAN DE ENGELSE, ZWEEDSE EN NEDERLANDSE GEZONDHEIDSZORG}

\section{Proefschrift}

ter verkrijging van de graad van Doctor in de Geneeskunde aan de Rijksuniversiteit Limburg te Maastricht

op gezag van de rector magnificus Prof. dr. W.H.F.W. Wijnen, hoogleraar in de Faculteit der Geneeskunde, volgens besluit van het College van Dekanen in het openbaar te verdedigen op vrijdag 21 maart 1980, des namiddags om vier uur precies in de Aula der Universiteit.

door

Guus Schrijvers

geboren te Amsterdam 
Promotores:

Prof. dr. L.M.J. Groot, Prof. dr. J.C.M. Hattinga Verschure,

Promotiecommissie:

Prof. dr. H.A.W.M. Tiddens, Prof. dr. H. Philipsen. 


\section{INHOUDSOPGAVE}

Lijst van gebruikte afkortingen

Voorwoord

Hoofdstuk 1 Inleiding op het onderzoek

$\begin{array}{ll}\text { 1.1. } & \text { Regionalisatie in Nederland } 1965-1978 \\ \text { 1.2. } & \text { Probleemstelling van deze studie } \\ \text { 1.3. } & \text { Onderzoekmethode } \\ \text { 1.3.1. } & \text { Onderzoekopzet } \\ \text { 1.3.2. } & \text { Gegevensverzameling } \\ \text { 1.3.3. } & \text { Omschrijving van een antal begrippen }\end{array}$

Hoofdstuk 2 Regionalisatie en financiering van de Engelse gezondheidszorg 1948 - 1974

2.1 .

2.1.1.

Algemene kenmerken van Engeland

Demografie en macro-economische kenmerken

2.1.2.

2.1.3.

Gezondheidstoestand van de bevolking

Organisatie van het overheidsbestel

2.2 .

2.3 .

2.4 .

2.4.1.

Organisatiestruktuur van de gezondheidszorg $1948-1974$

Besluitvormingsstruktuur van de gezondheidszorg 1948 1974

Doelstellingen gezondheidszorg

Niveau en kwaliteit handhaven

Afremming kostengroei

2.4.2.

Evenwichtige geografische spreiding

2.4.3.

2.4.4.

Integratie zorgverlening

Vergroten betrokkenheid van patiënten en medewerkers

2.4.5.

Hoofdstuk 3 Regionalisatie en financiering van de Engelse gezondheidszorg sinds 1974

Inleiding

3.1 .

3.2 .

Organisatiestruktuur van de NHS vanaf 1 april 1974

3.2.1.

Organisatiestruktuur van de gezondheidszorg binnen een health district

Besluitvormingsstruktuur van de NHS vanaf 1 april 1974

Planning van de aktiviteiten en de capaciteiten

Het financieringsstelsel

3.3.2.1.

Regionale financiering: periode 1974/1975 tot en met $1976 / 1977$

RAWP-voorstellen voor de periode vanaf 1977/1978

Financiering exploitatie

Financiering van faciliteiten van onderwijs aan medische

Financiering van investeringen 
Hoofdstuk 4 Regionalisatie en financiering van de Zweedse gezondheidszorg

4.1 .

Algemene kenmerken

4.1.1.

Demografische en macro-economische kenmerken

4.1.2.

4.1.3.

4.2 .

4.3 .

4.3.1.

Gezondheidstoestand van de bevolking

Organisatie van het overheidsbestel

Organisatiestruktuur van de gezondheidszorg

Besluitvormingsstruktuur van de gezondheidszorg

4.3.2.

Besluitvorming over aktiviteiten en capaciteiten

Het financieringsstelsel

4.4.

4.4.1.

4.4.2.

4.4.3.

4.4.4.

4.4.5.

4.4.5.1.

Doelstellingen gezondheidszorg

75

76

77

79

84

84

Niveau en kwaliteit handhaven

86

Afremming kostengroei

Evenwichtige geografische spreiding

Integratie zorgverlening

90

90

94

98

Vergroten betrokkenheid van patiënten en medewerkers

101

Satisfactie van patiënten en medewerkers

101

4.4.5.2.

Inspraak van patiënten en medewerkers

Hoofdstuk 5 Regionalisatie en financiering in de Nederlandse gezondheidszorg

5.1 .

5.1.1.

5.1.2.

5.1.3.

5.2 .

5.2.1.

5.2.2.

5.3 .

5.3.1.

5.3 .2 .

5.4 .

5.4.1.

5.4.2.

5.4.2.1.

5.4.2.2.

5.4.2.3.

5.4.3.

5.4 .4 .

5.4 .5 .

5.4.5.1.

5.4.5.2.

Algemene kenmerken van Nederland

Demografische en macro-economische kenmerken

Gezondheidstoestand van de bevolking

106

Organisatie van het overheidsbestel

107

Organisatiestruktuur van de gezondheidszorg

108

Landelijke organen

109

Te verwachten struktuur volgens Struktuurnota Gezondheidszorg van 1974

Besluitvormingsstruktuur van de gezondheidszorg

Besluitvorming over aktiviteiten en capaciteiten

111

Het financieringsstelsel

Doelstelling gezondheidszorg

Niveau en kwaliteit handhaven

Afremming kostengroei

Restrictief vergunningenbeleid

Restrictief tarievenbeleid

Afremming van de groei van de premiedruk

123

Evenwichtige geografische spreiding

123

Integratie zorgverlening

128

Vergroten betrokkenheid van patiënten en medewerkers $\quad 129$

Satisfactie van patiënten en medewerkers

129

Inspraak van medewerkers en patiënten 
Hoofdstuk 6 Regionalisatie en financiering van de Nederlandse gezondheidszorg op middellange termijn

6.1. Inleiding

6.2.

Algemene kenmerken

6.2 .1 .

Demografische en macro-economische kenmerken

133

6.2 .2 .

Gezondheidstoestand van de bevolking

133

6.2.3.

Organisatie van het overheidsbestel

136

6.3.

Organisatiestruktuur van de gezondheidszorg

6.4 .

Besluitvorming over aktiviteiten en capaciteiten

6.4.1.

6.4.2.

6.4.3.

6.5 .

6.5 .1 .

6.5.2.

6.5.3.

6.5 .4

6.5.5.

6.6 .

6.6.1.

Het arts/patiënt- en instellingsniveau

Het regionale niveau

Het nationale niveau

Het financieringsstelsel

Het arts/patiënt- en instellingsniveau 144

Het regionale niveau $\quad 147$

Het nationale niveau $\quad 149$

Financiering van investeringen $\quad 151$

Samenvatting van de voorwaarden voor een financieringsstelsel in een regionale organisatiestruktuur

Doelstellingen gezondheidszorg

6.6.2.

Niveau en kwaliteit handhaven

Afremming kostengroei

155

6.6.3.

Evenwichtige geografische spreiding

155
158

6.6.4.

Integratie zorgverlening

6.6.5.

Vergroten betrokkenheid van patiënten en medewerkers

6.6.5.1.

Satisfactie van patiënten en medewerkers

6.6.5.2.

Inspraak van patiënten en medewerkers

161

6.6.6.

Samenvatting van de bijdragen van het financieringsstelsel aan het bereiken van thans in Nederland geldende doelstellingen

Hoofdstuk 7 Nabeschouwing

163

7.1 .

Mogelijkheden voor een ontwikkelingsproces

163

7.2 .

Resultaten van het onderzoek en de in Nederland gaande discussie over regionale financiering

7.2.1.

Definitorische vraagstukken

7.2 .2 .

Tariefstelsel en budgetfinanciering

7.2.3.

Funktionele en regionale financiering

Samenvatting

Summary

Sammanfattning

Lijst van geciteerde literatuur

Lijst van geraadpleegde personen

Trefwoordenregister 


\section{LIJST VAN GEBRUIKTE AFKORTINGEN}

Afkortingen Betekenis

AFBZ Algemeen fonds bijzondere ziektekosten

AHA Area Health Authority

AWBZ Algemene Wet Bijzondere Ziektekosten

BMJ British Medical Journal

BNP Bruto Nationaal Produkt tegen marktprijzen

BoG Board of Governors

CBS Centraal Bureau voor de Statistiek

CMC Central Manpower Committee

CMND Command

COGT Centraal Orgaan Gezondheidszorg Tarieven

$\mathrm{COZ}$ Centraal Orgaan Ziekenhuistarieven

CRV Centrale Raad voor de Volksgezondheid

CVZ College voor Ziekenhuisvoorzieningen

DGH District General Hospital

DHSS Department of Health and Social Security

DMT District Management Team

EC Executive Council

EG Europese Gemeenschap

EMS Emergency Medical Service

FPC Family Practitioners Committee
Pagina, waarop de afkorting voor het eerst gebruikt wordt 
GG \& GD Gemeentelijke Geneeskundige en Gezondheidsdienst

$\begin{array}{ll}\text { GHI Geneeskundige Hoofdinspectie } & 108\end{array}$

$\begin{array}{lll}\text { GSS } & \text { Government Statistical Service } & 13\end{array}$

HESG Health Economics Study Group XI

HMC . Hospital Management Committee 23

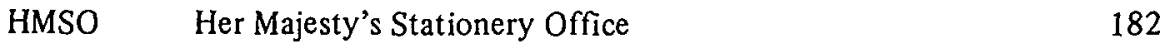

HSSJ Health and Social Services Journal 182

KNMG Koninklijke Nederlandse Maatschappij ter 6

LATT Läkares arbetstider och tjänster $\quad 85$

LHA Local Health Authority 23

LISZ Landelijk Informatie Systeem Ziekenfondsen 125

LKELP Landstings Kommunal Ekonomisk Längstids 85

Ministerie Ministerie van Cultuur, Recreatie en Maatvan CRM schappelijk werk

Ministerie Ministerie van Volksgezondheid en Milieuvan V \& M hygiëne

NCK Nationaal Centrum voor kruiswerk

NHS National Health Service

NIPG Nederlands Instituut voor Preventie Geneeskunde

NVAGG Nederlandse Vereniging voor Ambulante Geestelijke Gezondheidszorg

NZI

Nationaal Ziekenhuis Instituut

NZR Nationale Ziekenhuisraad

OECD Organization for Economic Cooperation and Development

OHE Office for Health Economics 
OPCS Office of Population Census Scarveys

rapport- Rapport "Priorities for Health and Personal

Priorities Social Services"

PEP (-group) Political and Economic Planning (-group)

RAWP Resource Allocation Working Party

RCCS Revenue Consequences of Capital Schemes

RHA Regional Health Authority

RHB Regional Hospital Board

RIAGG Regionaal Instituut voor de Ambulante Geestelijke Gezondheidszorg

RIGG Regionaal Instituut voor de Geestelijke Gezondheidszorg

RMC Regional Manpower Committee

SER Sociaal Economische Raad

SIFT Service Increment for Teaching

SK

Sveriges Kronor

SMR Standard Mortality Ratio

SOS Sveriges Officiella Statistik

SOSEL Stichting Ontwikkeling Samenwerkingsverbanden in de Eerstelijns gezondheidszorg

SPRI Sjukvardens och socialvardens planerings-och Rationaliserings Institut

THHR The Hospital and Health Services Review

Tss Tidskrift for Sveriges Sjukskoterkor

UK United Kingdom

v.c. variatie coëfficiënt

V.K. Verenigd Koninkrijk

z. uitg. zonder uitgever 


\section{VOORWOORD}

Sinds de jaren zestig wordt in Nederland aan een geografisch bestuurlijk indelen van de gezondheidszorg gedacht. Op dit moment is deze regionalisatie in het stadium van experimenten en wetsontwerpen. In Engeland is per 1 april 1974 een algehele reorganisatie van de gezondheidszorg ingevoerd. Deze heeft geleid tot het geografisch verdelen van het bestuur van de gezondheidszorg over Regional Health Authorities, Area Health Authorities en Health District Management Teams. In Zweden worden de ziekenhuizen van oudsher bestuurd door de landstingen, te vergelijken met de Nederlandse provincies. In de jaren vijftig en zestig krijgen deze landstingen de meeste andere voorzieningen voor gezondheidszorg, tot dan toe bestuurd door het rijk en de gemeenten, ook onder hun verantwoordelijkheid. Door deze verschuivingen wordt sinds het eind van de jaren zestig het grootste deel van de Zweedse gezondheidszorg regionaal bestuurd. Wat waren de overwegingen in Engeland en Zweden om tot regionalisatie over te gaan? Wat zijn de ervaringen ermee tot nu toe? Wat kan de Nederlandse gezondheidszorg ervan leren?

Deze vragen inspireerden mij om deze studie aan te vatten. Ze gaat over een deel van het regionalisatie-vraagstuk en wel dat deel, dat de financiering van de Nederlandse gezondheidszorg betreft. Ze bevat een descriptie van de struktuur en het funktioneren van de gezondheidszorg in Engeland, Zweden en Nederland. Door de verschillende strukturen en funktioneringswijzen te vergelijken wordt getracht voor de middellange termijn een aantal voorwaarden voor een financieringsstelsel van een geregionaliseerde gezondheidszorg in Nederland te formuleren. Het onderzoek is inductief van aard: hoofdzakelijk vanuit een beschouwing van de bestaande werkelijkheid wordt getracht tot de formulering van deze voorwaarden te komen. Deze wijze van wetenschapsbeoefening lijkt voor de bestudering van de struktuur en het funktioneren van de gezondheidszorg in een behoefte te voorzien: in de jaren zeventig zijn in verschillende West-Europese landen op deze leest geschoeide multidisciplinaire onderzoeksteams tot stand gekomen ter aanvulling van de deductieve benadering die meer vanuit een verdere ontwikkeling en toetsing van de bestaande theorie de werkelijkheid probeert te begrijpen.

Ik richt mij op dit onderzoek vanuit een aantal overwegingen. Ten eerste houdt het Instituut voor Ziekenhuiswetenschappen van de Medische Faculteit te Utrecht, waaraan ik ben verbonden, zich bezig met het bestuderen van de struktuur en het funktioneren van de gezondheidszorg, waarvan in het bijzonder de intramurale gezondheidszorg. Het doet dit inductief en vanuit verschillende disciplines. Als econoom aangesteld aan dit instituut lag dit onderzoek in mijn taakstelling. Ten tweede werd ik door de hoogleraren, prof. dr. L.M.J. Groot, hoogleraar gezondheidseconomie te Maastricht en prof. dr. J.C.M. Hattinga Verschure, directeur van genoemd instituut, gestimuleerd om dit onderzoek te doen. Het ligt voor de hand dat beiden als promotores voor dit proefschrift optreden. Ten derde $\mathrm{kwam} i \mathrm{k}$ via mijn lidmaatschap van de Health Economic Study Group (HESG) in 1975 in zijdelings kontakt met de juist gestarte reorganisatie in Engeland. De HESG is een vereniging van hoofdzakelijk Britse - economen, die wetenschappelijk werk verrichten op het gebied van de gezondheidszorg. Het secretariaat ervan ligt bij Tony Culyer, medewerker van het Institute of Social and Economic Research van de University of York. Tweemaal per jaar organiseert de HESG studiedagen voor de uitwisseling van onderzoekservaringen. De reorganisatie in 1974 en de gevolgen ervan kwamen op de HESG-studiedagen regelmatig aan de orde en boeiden mij in hoge mate. Tenslotte 
speelt mijn lidmaatschap van de gemeenteraad te Utrecht een rol in mijn motivatie. Als raadslid heb ik veel te maken met het toewijzen van financiële middelen binnen de gemeente Utrecht.

Het resultaat van deze studie dank ik mede aan:

- mijn beide promotores, prof. dr. L.M.J. Groot en prof. dr. J.C.M. Hattinga Verschure voor hun begeleiding en praktische adviezen tijdens het onderzoek.

- prof. A. Williams te York (Engeland) en prof. R. Berfenstam (Zweden) voor hun adviezen naar aanleiding van interim-rapporten over de gezondheidszorg in hun landen.

- mijn collega's binnen het Instituut voor Ziekenhuiswetenschappen voor hun steun en adviezen. Deze collega's zijn: drs. J.M. Boot, drs. J. Zuidberg, beiden sociologen, ir. A.J. Weeber, bedrijfskundige en mr. C. Mertens-Alons, juriste.

- acht doctoraal studenten van ons Instituut die doctoraalscripties schreven over studie-reizen in Engeland en Zweden. Deze studenten zijn: Hans Borgsteede, Geert Mensing, Karel Stegenga, Henk Stoop, Marjolijn Brasz, Jos Mul, Jan Bekker en Rob Merckens.

- het bestuur van de Medische Faculteit Utrecht, dat mij in staat stelde de noodzakelijke reizen te maken.

- mevrouw W. Ruigrok-Oldenhave, die vaak in overuren als bibliothecaresse van ons instituut literatuur voor dit onderzoek vergaarde en ordende.

- Frank Reeves, tot voor kort directeur van het King's Fund College te Londen, en Göta Annerstedt, medewerkster van het bureau internationale kontakten van de Socialstyrelsen te Stockholm. Beiden boden mij uitstekende introdukties tot funktionarissen in de gezondheidszorg in Engeland en Zweden.

- de zestig respectievelijk dertig geïnterviewde personen in Engeland en Zweden. Zij waren bereid mijn uitgebreide vragen te beantwoorden ondanks vaak volle agenda's.

- de achttien geraadpleegde personen, werkzaam bij verschillende instanties in Nederland. Hun kommentaar op het concept van het voorlaatste hoofdstuk is mij bij de ontwikkeling van de definitieve versie zeer van pas gekomen.

- Galina de Keijzer, Caroline van Amersfoort, Violet Beulenkamp. Zij hebben vele concepten en interim-rapporten uitgetikt.

Ondanks alle medewerking en steun van bovengenoemde personen berust uiteraard de verantwoordelijkheid van deze studie geheel bij ondergetekende.

Utrecht, oktober 1979

Guus Schrijvers 


\section{INLEIDING OP HET ONDERZOEK}

\subsection{REGIONALISATIE IN NEDERLAND $1965 \cdot 1978$}

Sinds het midden van de jaren zestig wordt in Nederland regionalisatie van gezondheidszorgvoorzieningen meer en meer bepleit.

In de Volksgezondheidsnota $1966(96)^{*}$ wijzen minister Veldkamp en staatssecretaris Bartels op het belang ervan vanwege "de complexe samenhang van het hoog gespecialiseerde ziekenhuis- en inrichtingswezen, (--) de behoefte aan het tot standbrengen van verpleegeenheden in de wijken en (---) de noodzaak van wederzijdse aanvulling van wijkgezondheidszorg en het ziekenhuis- en inrichtingswezen" (96, p. 160 ). Ook vinden zij een regionalisatie van de behoefteramingen onvermijdelijk, omdat "het op geen enkele andere wijze mogelijk is de programmering van de behoefte aan voorzieningen op het gespecialiseerde en minder gespecialiseerde niveau in onderlinge samenhang te beschouwen. Dit vereist organisatorische voorzieningen. Zonder organisatorische voorzieningen kan een verantwoord beslag leggen op de nationale middelen voor de volksgezondheid niet worden doorgevoerd" $(96$, p. 169). Voor en na het verschijnen van deze nota komen verschillende andere publicaties over regionalisatie uit.

Eind 1965 spreekt Hattinga Verschure (54) van een chaos op het gebied van de regionale ziekenhuissituaties. Hij pleit voor regionale afspraken voor het verdelen van bedden, specialismen en specialisten over ziekenhuizen, alsmede voor optimale nazorgregelingen tussen ziekenhuizen en kruisverenigingen en beter samenspel tussen ziekenhuizen, verpleeghuizen en artsen $(43$, p. 11$)$.

In 1966 betoogt Muntendam (71) op grond van dezelfde argumenten als van de Volksgezondheidsnota 1966 dat toenemende regionale samenwerking tussen ziekenhuizen is geboden en dat zonder medewerking van de rijksoverheid geen ordening in het ziekenhuiswezen is te effectueren (71, p. 190).

Een jaar later spreekt Stolte zich uit voor een regionalisatie, waarbij "de wetgever aan de regio's grote uitvoerende bevoegdheden dient te delegeren onder voorbehoud van een zo groot mogelijke bewegingsvrijheid van instellingen en leden van de professies" $(91$, p. 18).

In datzelfde jaar gaat De Vreeze ervan uit, dat de noodzaak van regionalisatie geen vraag meer is. Hij beschouwt een institutionalisering ervan als onvermijdelijk. Een zekere inperking van de autonomie van ziekenhuizen lijkt hem in overeenstemming met de eisen van de samenleving $(97$, p. 52-54).

In 1969 ziet Vissers als kernprobleem van de noodzaak tot regionalisatie "de doelmatigheid bij het scheppen van voorzieningen en een goede spreiding van deze" (95, p. 97).

In 1971 wordt in Medisch Contact door een groot aantal auteurs gediscussieerd over de toekomstige struktuur van de gezondheidszorg. Hierbij wordt vanwege de bovengenoemde redenen gepleit voor regionalisatie door Andriessen (5), Veder-Smit (93) en Siderius (89). In datzelfde jaar wordt de Wet Ziekenhuisvoorzieningen van kracht (107). In deze wet krijgen de provinciebesturen de taak om de Minister van Volks-

* (96) wil zeggen: zie lijst van geciteerde literatuur op pagina 177 van dit boek, nr. 96. 
gezondheid en Milieuhygiëne ( $V$ \& $M$ ) een plan voor te leggen, waarin de omvang van de behoefte aan ziekenhuizen is aangegeven. Op basis van de provinciale plannen stelt de minister dan een landelijk ziekenhuisplan vast. Het inschakelen van de provincies wordt fundamenteel geacht, omdat slechts op die manier met plaatselijke faktoren rekening gehouden kan worden. "In ons land heeft men zich in het verleden bij de planning in eerste aanleg te veel gericht op het landelijk niveau en te weinig op het regionale", heet het in de Memorie van Toelichting op deze wet (Wet Ziekenhuiswoorzieningen, 107).

Op 19 oktober 1972 geeft de Minister van Volksgezondheid en Milieuhygiëne, dr. L.B.J. Stuyt aan drie samenwerkende organisatiebureau's de opdracht een onderzoek in te stellen naar de beheersbaarheid van de gezondheidszorg. In hun rapport (Berenschot , 8) in 1973 zien de bureau's als voordelen "afstemming van voorzieningen op elkaar en op de behoeften van de bevolking", "optimale geografische en funktionele toegankelijkheid", "een snellere bijsturing van plannen omdat er een regionaal besluitvormingsniveau ontstaat" en "voeding van de centrale plannen door regionale plannen".

Als problemen noemen zij "aantasting van de autonomie van de afzonderlijke elementen in een regio", "grote meningsverschillen over de gewenste omvang van een regio" en "een gebrek aan aansluiting op de bestaande bestuurlijke regionale organen". Ofschoon zij deze problemen niet willen onderschatten, zijn zij van mening dat de voordelen de problemen verre overtreffen. $\mathrm{Zij}$ adviseren dan ook tot een regionalisatie met regionale raden als besluitvormende organen (8, p. 116-124). In hetzelfde jaar komt de Centrale Raad voor de Volksgezondheid met een advies over de regionalisatie (31).

Deze Raad stelt als kernpunt van het advies: "Effectieve, funktionele regionalisatie in de vorm van een indeling van ons land in reëel overzienbare gebieden, met als doel de totale gezondheidszorg daarbinnen kritisch te beoordelen en in aansluiting hierop door bijsturen, aanpassen en ombuigen geleidelijk verbeteringen en vernieuwingen aan te brengen, ziet de Raad als een mogelijke weg, waarlangs de noodzakelijke wijziging zou kunnen worden bereikt. Daarbij zal ook gestreefd moeten worden naar een doorzichtiger struktuur van de gezondheidszorg, alsmede naar meer samenwerking in het besef van een gezamenlijke verantwoordelijkheid" $(31$, p. 1$)$.

Eveneens in 1973 stelt de nieuw benoemde staatssecretaris Hendriks een commissiead-hoc in met de opdracht zich te beraden over de mogelijkheid tot verbetering van de gezondheidszorg en het funktioneren ervan op korte termijn.

Ook in het rapport van deze Commissie-Festen (1) wordt regionalisatie als een van de hulpmiddelen genoemd tot beheersing van de gezondheidszorg. In 1974 brengt staatssecretaris Hendriks de "Struktuurnota Gezondheidszorg" (Ministerie van V \& $M, 68$ ) uit. In deze nota wordt regionalisatie gezien als "een van de strukturele middelen om te komen tot een doelmatig opgebouwde en doeltreffend funktionerende gezondheidszorg" $(68$, p. 10). Als uitvloeisel van deze struktuurnota komt in de jaren na 1974 een aantal proefregio's tot stand, waar ervaringen worden opgedaan met regionale samenwerking (Tweede Kamer, 92). In 1977 wordt het ontwerp Wet Voorzieningen Gezondheidszorg (106) bij de Tweede Kamer der Staten-Generaal ingediend. Dit wetsontwerp is te zien als een uitbreiding van de oorspronkelijke Wet Ziekenhuisvoorzieningen van 1971. Niet alleen de planning van in tramurale instellingen maar die van alle voorzieningen wordt erin geregeld, waarbij de rol van de provincie te vergelijken is met die in de Wet Ziekenhuisvoorzieningen van 1971 .

In de discussie over de regionalisatie wordt de laatste jaren ook de financiering van de gezondheidszorg betrokken. In 1973 komt een commissie van de Sociaal Economische Raad (SER) (90) na vijf jaar studie met een nota over de gewenste struktuur 
van de verzekeringen tegen kosten van geneeskundige verzorging. De nota bevat vier plannen, afkomstig van achtereenvolgens de ziektekostenverzekeraars, de vakcentrales, Van Mansvelt en Cohen, en als vierde Drogendijk. In verschillende plannen wordt aandacht besteed aan de vorming van regionale raden (organen), die de besteding van financiële middelen moeten controleren. In oktober 1973 pleit $D e$ Vries (98) voor een volksverzekering tegen ziektekosten, waarbij een deel van de premie door regionale organen wordt geheven.

In de Struktuurnota Gezondheidszorg wordt gedacht aan een systeem met budgetten voor regio's. "Dit (budgetsysteem - G.S.) lijkt een niet onaantrekkelijke gedachte. Zeker wanneer het mogelijk zou blijken te zijn om het budgetsysteem op regionaal niveau door te voeren. De verantwoordelijkheid van de regio voor de gezondheidszorg zou hiermede nog beter tot haar recht kunnen komen" (Ministerie van $V$ $\& M, 68, \mathrm{p} .26)$.

In een rede voor de Nederlandse Vereniging voor Ziekenhuiseconomen stelt Groot (49), dat budgettering door een regio-bestuur vanuit het oogpunt van democratisering uitzonderlijk belangrijk is. In een markteconomie vervult het geld de rol van het stembiljet, waarbij de deelnemer op een zeer genuanceerde wijze bepaalt wat de samenleving wil consumeren en produceren. Aangezien in de gezondheidszorg het marktmechanisme niet aanwezig is, aldus Groot, moeten de beslissingen over consumeren en produceren via het politieke stembiljet genomen worden.

Indien de regio dan beslist over zijn eigen budget voor gezondheidszorg kunnen de meeste betrokkenen - de regio-bevolking - via het stembiljet de meeste invloed uitoefenen. Nationale kaders zullen hierbij dan wel een rol spelen $(49$, p. 20). Op zijn rede komen reakties van verschillende kanten. De plaatsvervangend directeur-generaal van het Ministerie van Volksgezondheid en Milieuhygiëne, Elsen, stelt het op prijs, zo blijkt onmiddellijk na de redevoering, als bepaalde organisaties dit probleem uitvoerig zouden gaan bestuderen.

Dijkstra (41) stelt in 1975 dat budgetten niet als kostenlimiet van de aktiviteiten van de gezondheidszorg mogen werken. Het nationale gezondheidsbudget moet van onderop tot stand komen. Alleen voor regionale afstemming hebben dan in te stellen regionale raden beslissingsbevoegdheid nodig om budgetten aan te passen (41, p. 594). De gedachte dat aktiviteiten de - regionale - budgetten moeten bepalen vinden wij behalve bij Dijkstra, ook bij Groot (49), Domela Nieuwenhuis (38), Poels (79), De Wit (109), Ter Heyde en Kalff (55) en Chardon (28).

In september 1975 lekt het concept van het ontwerp van Wet Verzekeringen Gezondheidszorg (103) uit. Dit wetsontwerp dat nooit officieel bij het parlement is ingediend, beoogt door een samenvoeging van particuliere en ziekenfondsverzekeringsinstellingen één volksverzekering tegen ziektekosten tot stand te brengen. In de Memorie van Toelichting wordt een regionaal budgetsysteem opnieuw een aantrekkelijke gedachte genoemd.

In 1976 beschrijft Idenburg de regionalisatie van de Nederlandse gezondheidszorg. Hij komt dan tot de opvatting, dat "een serieuze poging tot decentralisatie van het volksgezondheidsbeleid noodzaakt te zoeken naar de eén of andere vorm van gedecentraliseerde financiering" (57, p. 456).

In datzelfde jaar stellen Ter Heyde en Kalff (55) dat regionale budgettering de kostenbeheersing zal verzwakken. Er zullen achterstandsregio's ontstaan, die zullen streven naar het niveau van de regio's met de meeste voorzieningen $(55, \mathrm{p} .83)$. Hun opvattingen worden gedeeld door Van Doorn en De Leeuw (39).

In 1977 brengt de Centrale Raad voor de Volksgezondheid een advies uit over regionale financiering van de gezondheidszorg (33). Een voorstel wordt gedaan voor een experiment met regionale financiering (p. II). Gepleit wordt voor een model met fi- 
nanciering van de gezondheidszorg uit twee fondsen. Uit een eerste fonds worden de kosten voldaan voor het gebruik van landelijk bepaalde voorzieningen. Uit een tweede geldstroom ontvangt de regio gelden, die ze naar eigen beleid mogen besteden (33, p. 10). In datzelfde jaar wordt door het Ministerie van V \& M een werkgroep ingesteld om de mogelijkheid te bespreken van het opzetten van experimenten voor de budgettering van en in ziekenhuizen. Aan de werkgroep nemen deel vertegenwoordigers van het Centraal Orgaan Ziekenhuistarieven (COZ), Nationaal Ziekenhuis Instituut (NZI), Nationale Ziekenhuisraad (NZR), Ziekenfondsraad, Vereniging van Nederlandse Ziekenfondsen en de Kontaktkommissie Landelijke Organisaties van Ziektekostenverzekeraars. Hoewel regionale financiering buiten de reikwijdte van deze werkgroep valt, wordt wel een aantal hierbij te hanteren begrippen in de in 1978 uitgebrachte nota (Ministerie van V \& M, 70) gedefinieerd (zie paragraaf 7.2.1.).

In 1978 brengt de Ziekenfondsraad een discussienota uit over de budgettering van de gezondheidszorg. Hierin wordt gepleit voor het handhaven van een rechtstreekse financiering van werkeenheden vanuit een centrale kas. Wel kunnen regionale organen adviezen uitbrengen $(113$, p. 14-16).

\subsection{PROBLEEMSTELLING VAN DEZE STUDIE}

Dit onderzoek poogt bij te dragen aan de gedachtenvorming over één aspekt van de regionalisatie van de Nederlandse gezondheidszorg. Het gaat in op de gevolgen van de regionalisatie voor het financieringsstelsel van de gezondheidszorg. Getracht wordt in deze studie een antwoord te geven op de volgende vraag:

“Aan welke voorwaarden moet een financieringsstelsel van de Nederlandse gezondheidszorg voldoen, dat gebaseerd is op de volgende uitgangspunten:

1. een regionalisatie van de formele organisatiestruktuur van de gezondheidszorg;

2. het leveren van een positieve bijdrage aan het bereiken van thans geldende doelstellingen van het nationale beleid ten aanzien van de gezondheidszorg;

3. de mogelijkheid op middellange termijn te worden verwezenlijkt vanuit het thans bestaande financieringsstelsel."

Ter toelichting op deze probleemstelling is het volgende op te merken.

Het financieringsstelsel wordt omschreven als een formele struktuur die de besluitvorming over de middelen ter dekking van de exploitatiekosten en de vermogensbehoeften van de gezondheidszorg regelt. In deze omschrijving wordt met het begrip struktuur* een verzameling relaties tussen van de omgeving te onderscheiden elementen aangegeven, die al dan niet relaties met de omgeving hebben. Voorzover deze struktuur is vastgelegd in regels en schriftelijke stukken is er sprake van een stelsel of formele struktuur. Daarnaast bestaat de informele struktuur. Deze betreft de spontaan gegroeide, niet vastgelegde relaties tussen de elementen. Als elementen van het financieringsstelsel worden onderscheiden werkeenheden en instanties. Een werkeenheid is een element waar zorgverlening en besluitvorming plaatsvindt, bijvoorbeeld een ziekenhuis of een huisartsenpraktijk. Een instantie is een element, waar besluitvorming of advisering plaatsvindt over éen of meer aspekten van meer dan één werkeenheid. In Nederland is bijvoorbeeld het Centraal Orgaan Ziekenhuistarieven te zien als een instantie, die deels adviseert, deels beslist over de tarieven

* Met deze omschrijving wordt aangesloten op de formulering van In 't Veld (59). 
van intramurale werkeenheden (zie paragraaf 5.2.1.). De relaties tussen de elementen van het financieringsstelsel ofwel de financiële relaties betreffen het verwerven en/of beschikbaar stellen van de "middelen ter dekking van de exploitatiekosten en de vermogensbehoeften van de gezondheidszorg", ofwel van de financiële middelen. Het financieringsstelsel kent relaties met zijn omgeving, die wordt gevormd door de Nederlandse samenleving: de veroudering van de Nederlandse bevolking bijvoorbeeld beïnloedt het stichten van verpleeghuizen, dat wil zeggen van bepaalde werkeenheden van het financieringsstelsel.

Het financieringsstelsel wordt in deze studie gezien als een deel van de formele besluitvormingsstruktuur, die op haar beurt een deel is van de formele organisatiestruktuur van de gezondheidszorg. Deze twee laatste formele strukturen kennen beide dezelfde elementen en omgeving als het financieringsstelsel, maar onderscheiden meer relaties dan alleen de financiële. De formele besluitvormingsstruktuur regelt de formele besluitvorming ten aanzien van alle relaties van de gezondheidszorg. De formele.organisatiestruktuur betreft de formele regeling van alle handelingen van de gezondheidszorg, niet alleen van de besluitvorming, maar ook van de uitvoering van de zorgverlening.

In de omschrijving van het begrip financieringsstelsel wordt gesproken over besluitvorming. Hiermee wordt bedoeld de keuzebepaling ten aanzien van de elementen en relaties van het stelsel. De bepaling van de keuze van deze financiële relaties kan de keuzevrijheid, ofwel beslissingsruimte ten aanzien van andere relaties beperken. In deze studie zal bijvoorbeeld naar voren komen, dat de beslissingsruimte ten aanzien van financiële middelen wordt beperkt, indien over andere aspekten reeds besluiten zijn genomen. Andersom geldt deze afhankelijkheid ook: de beslissingsruimten van andere aspekten worden beperkt, indien ten aanzien van de financiële middelen de besluiten vaststaan. Met deze begripsomschrijving (vergelijk: In 't Veld (59)) zijn de eerste twee regels van de probleemstelling als volgt nader toe te lichten. De genoemde voorwaarden worden gesteld aan de elementen en relaties van het financieringsstelsel. Dit stelsel wordt in deze studie gezien in relatie tot de formele besluitvormingsstruktuur, de formele organisatiestruktuur en de omgeving van de $\mathrm{Ne}$ derlandse gezondheidszorg.

In de probleemstelling wordt het financieringsstelsel gebaseerd op drie uitgangspunten. Ze worden hieronder toegelicht.

Uitgangspunt één: regionalisatie van de formele organisatiestruktuur van de gezondheidszorg.

In Nederland is een of andere vorm van een regionalisatie van de formele organisatiestruktuur en de formele besluitvormingsstruktuur als deel daarvan te verwachten. Deze mag verwacht worden op grond van de beleidsvoornemens van de regering, die in de vorige paragraaf vermeld zijn. In deze studie wordt gepoogd een relatie te leggen tussen deze regionalisatie en het financieringsstelsel.

Uitgangspunt twee: het leveren van een positieve bijdrage aan het bereiken van thans geldende doelstellingen van het nationale beleid ten aanzien van de gezondheidszorg.

Het tweede uitgangspunt wordt in de probleemstelling opgenomen vanuit de veronderstelling, dat een stelsel of formele struktuur een bijdrage kan leveren aan het bereiken van een doelstelling ofwel het beleid beïnvloedt. Deze veronderstelling stoelt op de volgende drie overwegingen:

- formele strukturen kunnen randvoorwaarden zijn voor de vorming van het gezondheidszorgbeleid. Voor Nederlandse intramurale instellingen is het bijvoorbeeld op dit moment formeel niet mogelijk om extramurale instellingen financieel te ondersteunen. 
- formele strukturen zijn van belang als konflikt-oplossend instrument. Indien bijvoorbeeld in bepaalde gebieden twee werkeenheden tegenstrijdige financiële besluiten bepleiten - bijvoorbeeld beide willen uitbreiding van het funktiepakket, terwijl slechts ruimte hiervoor is voor één - kunnen formele algemene regels voor de besluitvorming bijdragen tot de oplossing hiervan.

- formele strukturen zijn van belang voor het inzicht in de besluitvorming. Door een formele struktuur kan duidelijk worden gemaakt, waar en door wie welke besluiten worden genomen. Hierdoor ontstaat de mogelijkheid tot beïnvloeding van deze besluiten door betrokken groepen en personen.

Er wordt in dit uitgangspunt gesproken over positieve bijdragen aan en niet over een garantie voor het bereiken van doelstellingen. Dit is een essentieel verschil, dat aan de hand van het volgende voorbeeld te verduidelijken is. Het vergroten van de betrokkenheid van patiënten en zorgverleners bij de verleende zorg is één van de thans geldende doelstellingen van het nationale gezondheidszorgbeleid. Het bereiken van deze doelstelling wordt beinvloed door verschillende faktoren, zoals de attitude van patiënt en zorgverlener, de mate van zelfzorg en mantelzorg van eerstgenoemde, de rechten en plichten van beiden, de specifieke kennis van de zorgverlener, de architektuur van de gebouwen en het financieringsstelsel. In deze studie wordt onderzocht, hoe de laatste faktor een bijdrage kan leveren voor onder andere het vergroten van de betrokkenheid. Deze beleidsbeinvloeding is echter beperkt, partieel en eventueel zelfs nihil, indien andere faktoren, zoals in het voorbeeld aangegeven, blokkerend werken.

Als thans vigerende doelstellingen van het nationale gezondheidszorgbeleid worden in deze studie geformuleerd:

1. handhaven en bevorderen van het niveau en de kwaliteit van de verleende gezondheidszorg.

2. afremming van de groei van de totale kosten van de gezondheidszorg.

3. het bereiken van een evenwichtige geografische spreiding van de gezondheidszorg.

4. verbeteren van de integratie van de zorgverlening, dat wil zeggen, van de afstemming van de verschillende soorten zorg, zowel onderling als op de maatschappelijke dienstverlening.

5. vergroten van de betrokkenheid van patiënten en medewerkers bij de verleende zorg.

Deze doelstellingen worden, zij het met wisselende nadruk, onderschreven door de meeste instanties en beroepsgroepen van de gezondheidszorg (Ministerie van $V \& M$ 68, p. 5 en 6, COZ - 27, CRV - 32, CVZ - 35 en 36, KNMG, LHV, LSV en $L A D-62$, $N V A G G-74$, Ziekenfondsraad - 112,NZR - 73 en het $N C K-72$, zie ook $A$. Schrijver (88)).

Uitgangspunt drie: de mogelijkheid op middellange termijn te worden verwezenlijkt vanuit het thans bestaande financieringsstelsel.

Uit een eerder onderzoek verricht vanuit het Instituut voor Ziekenhuiswetenschappen is gebleken, dat in alle westerse landen het gezondheidsbeleid als een ontwikkelingsproces tot stand komt (Van der Werff, 101). Een dergelijk proces is te zien als het geleidelijk veranderen van bestaande strukturen waarbij de gewenste nieuwe strukturen slechts in algemene termen zijn geformuleerd. In deze studie wordt getracht in dergelijke algemene termen, te weten in de vorm van voorwaarden, een financieringsstelsel te schetsen, dat zich op middellange termijn kan ontwikkelen uit het bestaande stelsel. Gekozen is hierbij voor een ontwikkelingsperiode van een middellange termijn, dat wil zeggen voor een periode van circa vijf jaar. Voor deze termijn is gekozen om aan dit onderzoek een pragmatisch karakter te geven. 


\subsection{ONDERZOEKSMETHODE}

\subsubsection{Onderzoeksopzet}

De gekozen onderzoeksmethode start met beschrijvingen van de financieringsstelsels van de gezondheidszorg in een aantal landen, waaronder Nederland. In deze descripties worden op een systematische wijze van deze stelsels geinventariseerd:

- de kenmerkende elementen en relaties van de formele struktuur

- het funktioneren in de praktijk

- de positieve en negatieve bijdragen aan de in de probleemstelling genoemde doelstellingen ofwel de beleidsbeinvloeding.

$\mathrm{Na}$ deze beschrijvingen volgt een vergelijking van de financieringsstelsels, waarin de verschillende formele strukturen, funktioneringswijzen en vormen van beleidsbeinvloeding als alternatieven naast elkaar geplaatst worden. Op basis van deze vergelijking wordt geanalyseerd aan welke voorwaarden, zoals bedoeld in de probleemstelling, het financieringsstelsel moet voldoen.

Een onderzoek als het onderhavige is ook te starten met de ontwikkeling vanuit de * bestaande wetenschap van een model van een financieringsstelsel binnen een geregionaliseerde gezondheidszorg. Dit model moet dan worden getoetst op de praktijk in verschillende landen. Indien het deze praktijk voldoende kan verklaren, kunnen vervolgens de voorwaarden, bedoeld in de probleemstelling, worden geformuleerd. Deze methode is niet gekozen, omdat betwijfeld werd of uit de bestaande ervoor in aanmerking komende wetenschappen - economie, gedragswetenschappen en geneeskunde - op eenvoudige wijze een model is af te leiden. Gevreesd werd voor een lange ontwikkelingstijd van het model.

Gekozen werd voor Engeland en Zweden als te vergelijken landen. De keuze viel op deze landen, omdat beide tegenwoordig regionale strukturen voor de gezondheidszorg kennen. Daarnaast werden voldoende overeenkomsten verwacht met de thans in Nederland geldende doelstellingen. Deze verwachting is onder andere gebaseerd op het volgende citaat in de Struktuurnota Gezondheidszorg "Bij de opstelling van deze nota heeft de vergelijking met de ontwikkeling in het buitenland mede geleid tot de naar voren gebrachte gezichtspunten. Uiteraard heeft vergelijking met andere landen alleen zin indien van vergelijkbare situaties sprake is. Daarom werd de oriëntatie beperkt tot die landen die in grote lijnen eenzelfde sociaal-economische en politieke struktuur hebben als ons land, benevens een hoog ontwikkeld systeem van sociale verzekeringen en een nagenoeg identiek patroon van problemen van ziekte en gezondheid. Op grond van deze kenmerken ligt een vergelijking met de ontwikkeling in de Scandinavische landen en het Verenigd Koninkrijk voor de hand" (Ministerie van V $\& M, 68$ ).

Deze studie bestaat uit drie gedeelten (zie schema 1.3.1.): ten eerste een inventariserend onderzoek voor elk van de drie landen (hoofdstukken $2 \mathrm{t} / \mathrm{m} 5$ ), ten tweede een vergelijking van de drie landen op basis waarvan de voorwaarden voor het financieringsstelsel voor de Nederlandse gezondheidszorg worden geformuleerd (hoofdstuk 6 ) en ten derde een nabeschouwing met een aantal mogelijkheden voor een ontwikkelingsproces voor een dergelijk stelsel in Nederland (hoofdstuk 7).

In het inventariserende deel worden per land overeenkomstige gegevens verzameld. Voorzover gegevens beschikbaar waren, is dit gedaan over de periode vanaf 1950 . Op deze wijze wordt getracht de invoering van regionale strukturen in Engeland en Zweden historisch te volgen. Beiden kenden namelijk rond 1950 slechts in beperkte mate dergelijke strukturen. Het inventariserend onderzoek in Engeland wordt beschreven in twee hoofdstukken. Hoofdstuk 2 over de periode tot 1 april 1974 en 
I Inventarisatie van de gezondheidszorg in Engeland (Hoofdstuk 2 en 3), Zweden (Hoofdstuk 4) en Nederland (Hoofdstuk 5)

1. Omgeving van de gezondheidszorg

- demografische opbouw bevolking

- Bruto Nationaal Produkt en enkele andere macro-economische variabelen

- gezondheidstoestand van de bevolking

- organisatie van het overheidsbestel

2. Formele organisatiestruktuur van de gezondheidszorg

- indeling gezondheidszorg naar zorgsoort

- indeling gezondheidszorg naar bestuurlijke instantie

3. Formele besluitvormingsstruktuur van de gezondheidszorg

- besluitvorming over aktiviteiten, arbeidsplaatsen, kapitaalgoederen en organisatiestruktuur

- het financieringsstelsel: besluitvorming over financiële middelen

- vier organisatieniveau's, waar besluitvorming plaatsvindt, te weten het arts-patiëntniveau, het werkeenheidsniveau, het regionale niveau en het nationale niveau

4. Doelstellingen van de gezondheidszorg

- handhaven niveau en kwaliteit van de zorgverlening

- afremming kostengroei

- evenwichtige geografische spreiding

- integratie van de verschillende soorten zorg

- betrokkenheid van patiënten en medewerkers vergroten

II Formulering voorwaarden financieringsstelsel (Hoofdstuk 6)

1. Vergelijking Engelse, Zweedse en Nederlandse gezondheidszorg in overeenkomstige stappen als bij de inventarisatie; uitwerking uitgangspunten probleemstelling (par. 6.2. - 6.4.)

2. Formulering voor waarden financieringsstelsel Nederlandse gezondheidszorg (par. 6.5.)

3. Bijdrage aan doelstellingen (par. 6.6.)

III Mogelijkheden voor een ontwikkelingsproces (Hoofdstuk 7)

- een aantal technisch gezien, op korte termijn uitvoerbare ontwikkelingsmogelijkheden

- aansluiting deze studie op lopende discussies over het financieringsstelsel

hoofdstuk 3 over de periode na deze datum. Dit is gedaan, omdat per 1 april 1974 de Engelse gezondheidszorg volledig is gereorganiseerd.

Het inventariserend onderzoek is voor elk van de drie landen op dezelfde wijze opgebouwd. Achtereenvolgens worden van de gezondheidszorg de volgende vier onderwerpen beschreven:

1. de omgeving

2. de formele organisatiestruktuur

3. de formele besluitvormingsstruktuur

4. doelstellingen

Het financieringsstelsel komt aan de orde als onderdeel van de formele besluitvormingsstruktuur van deze landen. De beschrijving van elk van de vier onderwerpen concentreert zich op kenmerken, waarvan in elk van de drie landen vergelijkbare gegevens beschikbaar zijn en waarvan invloed op de zorgverlening aanwezig kan worden geacht.

De omgevingskenmerken bestaan uit variabelen, waarvan uit reeds verricht onder- 
zoek gebleken is, dat deze de zorgverlening beïnvloeden (Rutten, 84 en 85 en $O E C D$, 77). Deze variabelen zijn: de demografische opbouw, de ontwikkeling van het Bruto Nationaal Produkt en een aantal andere macro-economische variabelen, de gezondheidstoestand van de bevolking en tenslotte de organisatie van het overheidsbestel. Bij de tweede groep kenmerken, die de formele organisatiestruktuur betreffen, komt de indeling van de gezondheidszorg naar zorgsoort en naar bestuurlijke instanties aan de orde.

Als derde groep volgen de kenmerken van de formele besluitvormingsstruktuur. Er worden vijf kategorieën besluiten onderscheiden, te weten besluiten over achtereenvolgens aktiviteiten, arbeidsplaatsen, kapitaalgoederen, organisatiestruktuur en financiële middelen. De besluiten over de aktiviteiten gaan over de samenstelling en omvang van de te verlenen zorg. De besluiten over de arbeidsplaatsen betreffen zowel de spreiding van deze over de soorten arbeid als ook de geografische spreiding. Besluiten over het vestigingsbeleid en de arbeidsvoorwaarden van artsen en andere zorgverleners worden hierbij ook besproken. Bij de kapitaalgoederen is te denken aan de besluiten over de spreiding van gebouwen en apparatuur over het land en over de verschillende werkeenheden. Bij de organisatiestruktuur is allereerst te denken aan het regelen van bevoegdheden van funktionarissen, werkeenheden en instanties van de gezondheidszorg. Verder vallen hier beslissingen onder die het oprichten en opheffen als ook het splitsen en samenvoegen van (delen van) werkeenheden en instanties betreffen. De besluiten over financiële middelen betreffen zowel die ter dekking van de kosten als die ter dekking van de vermogensbehoefte. In deze studie worden de besluiten over de eerste vier kategorieën geplaatst tegenover die betreffende de financiële middelen. Hierdoor is aan te geven, hoe de eerste kategorieën besluiten de omvang van de financiële middelen beïnvloeden. Behalve deze kategorieën besluiten worden in de derde groep kenmerken ook vier organisatieniveau's of bestuurslagen onderscheiden, waar deze besluiten genomen kunnen worden, te weten het arts/patiënt-niveau, het werkeenheidsniveau, het regionale niveau en het nationale niveau. Op één niveau kunnen verschillende personen of instanties werkzaam zijn: op het nationale niveau in Nederland zijn bijvoorbeeld verschillende gezondheidszorginstanties werkzaam, zoals het Centraal Orgaan Ziekenhuistarieven en de Ziekenfondsraad.

De vierde groep kenmerken betreft de doelstellingen van de verleende gezondheidszorg. Zoals gezegd zijn deze kenmerken zo gekozen, dat ze in relatie staan tot de thans in Nederland geldende doelstellingen. Ze worden kwantitatief gemeten, indien gegevens in deze landen hiervoor beschikbaar zijn. Ontbreken deze gegevens, dan wordt volstaan met het weergeven van voorbeelden en opvattingen over deze kenmerken. Getracht wordt opvattingen van zowel patiënten, zorgverleners als beleidsfunktionarissen uit de betrokken landen te vermelden. Hieronder worden de kenmerken van de vierde groep achtereenvolgens per doelstelling aangegeven.

\section{Doelstelling 1: handhaven niveau en kwaliteit van de zorgverlening}

Als kenmerk voor het niveau wordt de ontwikkeling besproken van de aktiviteiten en kapaciteiten van de gezondheidszorg, benevens de mate waarin in de zorgbehoeften van de bevolking wordt voorzien. Het eerste kenmerk wordt kwantitatief gemeten. Het tweede komt aan de orde aan de hand van opvattingen in beleidsstukken en opmerkingen uit interviews, die in het kader van deze studie zijn gehouden. Er waren geen gegevens beschikbaar om de kwaliteit van de zorgverlening rechtstreeks te meten. Worden hiervoor wel morbiditeits- en mortaliteitscijfers gehanteerd, in het kader van deze studie waren deze niet bruikbaar, vanwege de aanwezigheid van teveel interveniërende variabelen. Deze cijfers worden daarom gehanteerd 
als omgevingskenmerk. Gekozen is in deze studie voor kwaliteitskriteria die de organisatiestruktuur van de zorgverlening betreffen en niet de zorgverlening zelf. Het gaat bij de strukturele kwaliteit om de mate van aanwezigheid van voorwaarden, die gunstig zijn voor een kwalitatief goede zorgverlening. De kwaliteitskriteria in deze studie betreffen de toegankelijkheid van de zorgverlening. Hierbij is te denken aan de aanwezigheid van werkeenheden in de direkte woonomgeving, zoals de huisarts en de wijkverpleegkundigen. Deze worden tezamen met andere curatieve zorgverleners in de direkte woonomgeving de eerstelijnsvoorzieningen genoemd. Bij de toegankelijkheid wordt ook gelet op de aanwezigheid van wachtlijsten en financiële drempels voor de verschillende soorten zorg. Deze kwaliteitskriteria worden, voorzover mogelijk, kwantitatief weergegeven.

\section{Doelstelling 2: afremming kostengroei}

Als kenmerken worden beschreven de groei van de bestedingen voor gezondheidszorg en de invloed van afwegingsprocessen ten opzichte van bestedingen anders dan aan gezondheidszorg. Ook wordt gekeken naar de aanwezigheid en invloed van besluitvormingsprocessen ten aanzien van bestedingen binnen de gezondheidszorg. De bestedingsgroei wordt kwantitatief gemeten. De twee andere kenmerken komen aan de orde aan de hand van voorbeelden uit het verleden en metingen uit de interviews van deze studie.

\section{Doelstelling 3: evenwichtige geografische spreiding}

Voorzover gegevens beschikbaar zijn worden verschillende soorten aktiviteiten, kapaciteiten, arbeidsplaatsen en kosten per 1000 inwoners en per regio vermeld.

\section{Doelstelling 4: integratie van de verschillende soorten zorg}

Aan de hand van voorbeelden en meningen uit de literatuur en de interviews wordt besproken:

- de kontinuiteit in de zorgverlening. Hier gaat het om de vraag, of de patiënt in staat is met dezelfde zorgverlener regelmatige kontakten te hebben.

- de samenwerking tussen werkeenheden, zowel op zorgverlenings- als op bestuurlijk niveau.

- de samenwerking met de maatschappelijke dienstverlening.

\section{Doelstelling 5: betrokkenheid van patiënten en medewerkers vergroten}

Aan de orde komen de satisfaktie van en de mate van inspraak voor patiënten en medewerkers. Bij de satisfaktie van de patiënten gaat het om de mate van tevredenheid met de zorgverlening. Er worden enkele satisfaktie-onderzoeken besproken, die in de drie landen gehouden zijn. De satisfaktie van de medewerkers betreft die met de werkomstandigheden. Deze satisfaktie wordt besproken aan de hand van opvattingen uit de literatuur en de interviews. Bij de inspraak wordt nagegaan, hoe de besluitvorming op bestuurlijk niveau te beïnvloeden is door patiënten en medewerkers. Met voorbeelden en ervaringen uit de literatuur en de interviews wordt gepoogd een beeld hiervan te schetsen.

Met de beschrijving van de bovenstaande doelstellingskenmerken wordt elk van de inventariserende onderzoeken per land en daarmee het eerste gedeelte van deze studie afgesloten. Het tweede gedeelte (hoofdstuk 6 ) bevat een vergelijking van de drie landen. De vergelijking tussen de drie landen gebeurt in dezelfde vier stappen als die van de inventariserende onderzoeken. Op basis hiervan wordt in paragraaf 6.2. - 6.4. een uitwerking gegeven van de uitgangspunten van de probleemstelling. Daarna wor- 
den voorwaarden geformuleerd voor het financieringsstelsel (par. 6.5.). De te verwachten bijdragen van een dergelijk stelsel aan de doelstellingen vormen het slot van het tweede gedeelte (par. 6.6.).

Het derde gedeelte van deze studie (hoofdstuk 7) is een nabeschouwing naar aanleiding van de resultaten van dit onderzoek. Dit deel valt buiten de probleemstelling van het eigenlijke onderzoek. Het bevat een aantal ontwikkelingsmogelijkheden, die technisch gezien op korte termijn uitvoerbaar lijken. Aan het eind van hoofdstuk 7 wordt ingehaakt op de in paragraaf 1.1. vermelde lopende diskussies over het financieringsstelsel.

\subsubsection{Gegevensverzameling}

Gegevens over de drie onderzochte landen werden verkregen door de raadpleging van literatuur, statistieken en andere schriftelijke stukken, door het houden van interviews met betrokkenen bij de besluitvorming, alsmede door observatie van de besluitvorming in de verschillende landen. De gehouden interviews waren gericht op het verkrijgen van toelichting en aanvulling op de eerstgenoemde bronnen. Tevens werden via de interviews schriftelijke stukken verkregen - zoals beleidsnota's, begrotingen, jaarverslagen, notulen van vergaderingen, evaluatie-rapporten - die niet als zodanig uitgegeven waren in boekvorm of in tijdschriften. De observatie van de besluitvorming bestond uit het bijwonen van vergaderingen van regio-besturen dan wel van commissies van deze. In Engeland werden zestig personen geinterviewd. In Zweden was dit aantal dertig (zie lijst van geraadpleegde personen op pagina 190).

In het eerste land werden meer interviews gehouden, omdat dit eerder in de tijd werd onderzocht. Dit leverde ervaringen op, waardoor in Zweden gerichter gewerkt kon worden. Van de Engelse geinterviewden waren er 42 werkzaam bij zes verschillende Area Health Authorities (AHA's). Van de Zweedse ondervraagden werkten er achttien bij vijf verschillende landstingen. Op de twee landkaarten op de volgende bladzijden (grafieken 1.3.2.1. en 1.3.2.2.) worden de gebieden aangegeven waar deze AHA's en landstingen het bestuur van vormen.

Zowel in Engeland als in Zweden liggen deze gebieden verspreid over het land. Getracht is op deze wijze ervaringen van verschillende regio's in het onderzoek te betrekken. Op de landkaarten staan ook de gebieden aangegeven waarover alleen schriftelijke stukken zijn geraadpleegd.

De overige geinterviewde personen in beide landen waren ofwel werkzaam op nationaal niveau ofwel bij wetenschappelijke instituten. De meeste ondervraagde personen hadden een deskundigheid op het gebied van organisatie, financiën en dergelijke. In Engeland werden elf artsen geinterviewd en in Zweden dertien.

In Nederland zijn geen personen geinterviewd, omdat binnen het Instituut voor $\mathrm{Zie}$ kenhuiswetenschappen te Utrecht reeds kennis aanwezig was over het te onderzoeken vraagstuk. Wel is een concept van het op basis van de ervaringen in Engeland en Zweden geschreven zesde hoofdstuk voorgelegd aan achttien bij het onderwerp betrokken personen in Nederland (zie lijst van geraadpleegde personen, pag. 190).

De opmerkingen van deze personen zijn bij de ontwikkeling van de definitieve versie zeer van pas gekomen.

\subsubsection{Omschrijving van een aantal begrippen}

De meeste begrippen in deze studie worden omschreven op het moment dat ze worden geintroduceerd. Een aantal veel gebruikte begrippen zal echter in deze paragraaf de revue passeren. Voor alle onderstaande omschrijvingen geldt, dat ze bedoeld zijn als leidraad voor dit boek en niet als voorstel voor een algemeen te hanteren termi- 


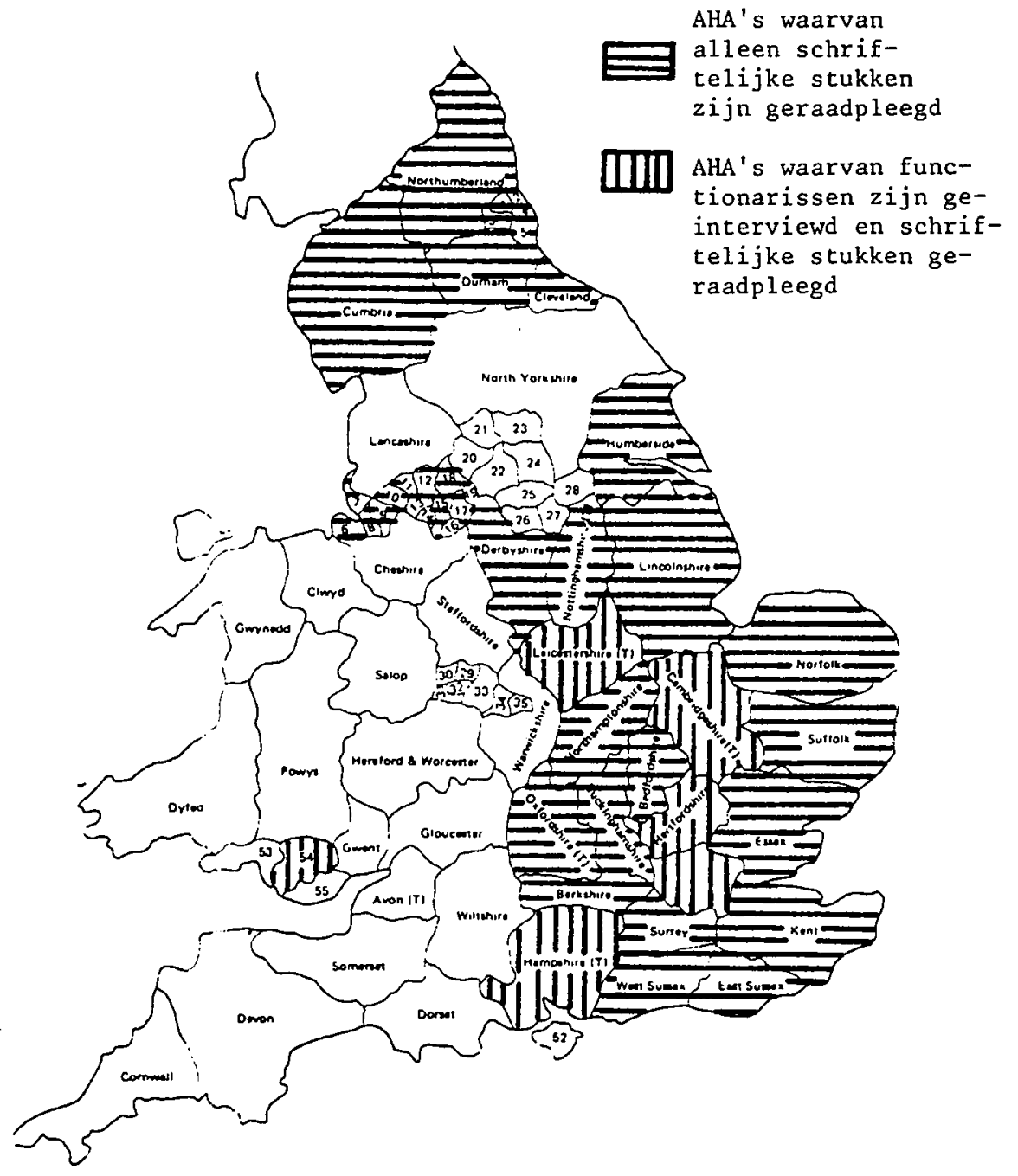

Index op genummerde Area Health Authorities

1 Newcastie Upon Tyne ( $T$ )

2 Northern Tyneside

3 Gateshead

4 Sunderland

5 Southern Tyneside

6 Wirral

7 Sefton
8 Liverpool (T)

9 St. Helens and Knowsley

10 Wigan

11 Bolton

12 Bury

13 Salford (T)

14 Trafford 


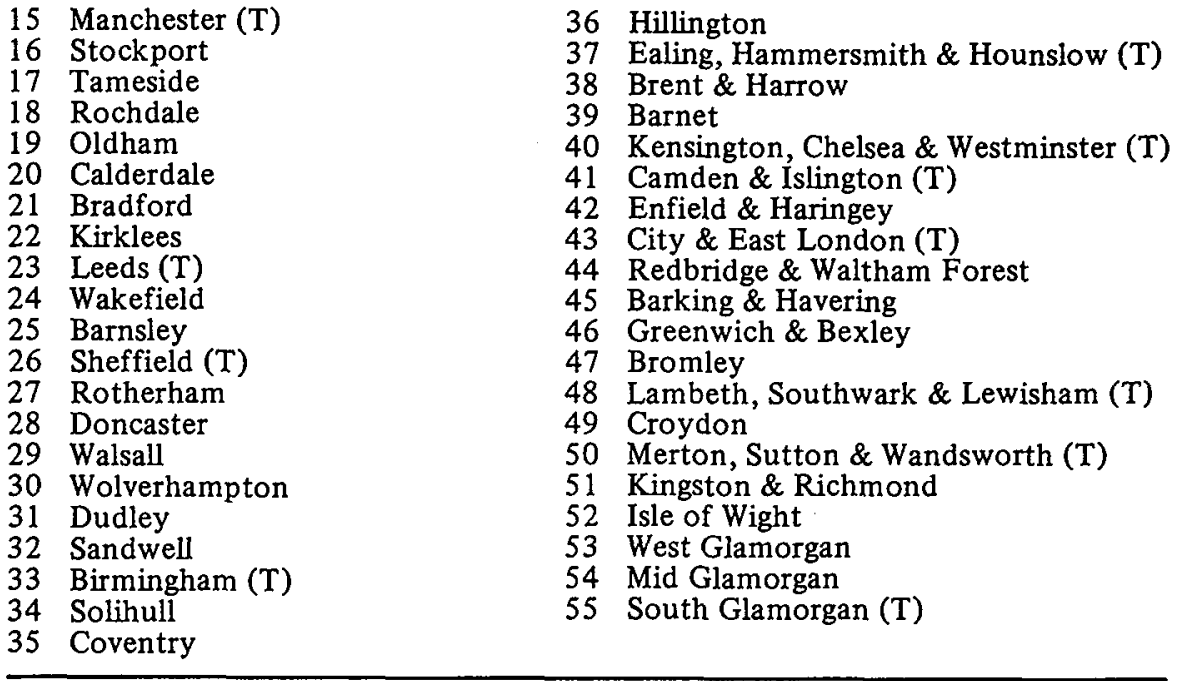

nologie. Bij de keuze van de omschrijving is getracht aan te sluiten bij het gangbare spraakgebruik.

Onder gezondheidszorg wordt verstaan de zorg verleend door de verzameling personen en instellingen, die vallen onder de begrippen gezondheidszorg, health services en hälso och sjukvård van de gezondheidsstatistieken van het Centraal Bureau voor de Statistiek (CBS) in Nederland, en de daarmee vergelijkbare zusterinstellingen de Government Statistical Service (GSS) in Engeland en de Sveriges Officiella Statistik (SOS) te Zweden. Gekozen is voor een omschrijving vanuit de verschillende gezondheidsstatistieken, omdat deze het beste aansluiten bij de gegevens over de regio's van die landen. Om deze reden is niet gekozen voor omschrijving vanuit de Nationale Rekeningen van de drie landen. De aktiviteiten van patiënten voor zichzelf en onderling ter bevordering van hun gezondheid, te noemen zelfzorg, mantelzorg, vrijwilligerswerk en zelfmedicatie, vallen buiten de hier gegeven statistische omschrijving van gezondheidszorg.

Onder de eerstelijnsgezondheidszorg of wijkgezondheidszorg wordt in dit onderzoek de zorgverlening verstaan van huisartsen, wijkverpleegkundigen, apothekers, fysiotherapeuten, vroedvrouwen, en (in Engeland) opticiens. De intramurale gezondheidszorg wordt verleend aan opgenomen patiënten in algemene en psychiatrische ziekenhuizen, verpleeghuizen en in zwakzinnigeninrichtingen. De overige soorten gezondheidszorg worden later in de tekst omschreven.

Onder de maatschappelijke dienstverlening (Engels: social services en Zweeds: social versamket) wordt in deze studie verstaan de aktiviteiten van maatschappelijk werk, gezinszorg, Gemeentelijke Sociale Diensten (bijstandsuitkeringen), bejaardenoorden, en van dienstencentra voor bejaarden, van waaruit onder andere maaltijden, boeken en (re-)creatieve aktiviteiten worden aangeboden. De afbakening van de begrippen gezondheidszorg en maatschappelijke dienstverlening is voor de drie landen niet geheel gelijk: de verpleeghuizen bijvoorbeeld vallen in Nederland alle onder gezondheidszorg en in Engeland voor een deel onder de maatschappelijke dienstverlening. Onder de term "health services" valt niet de particuliere gezondheidszorg in Engeland. Vier procent van de Engelse bevolking geeft in 1975 een bedrag van 1\% 
Grafiek 1.3.2.2. Overzicht van landstingen in Zweden, die betrokken zijn in het onderzoek

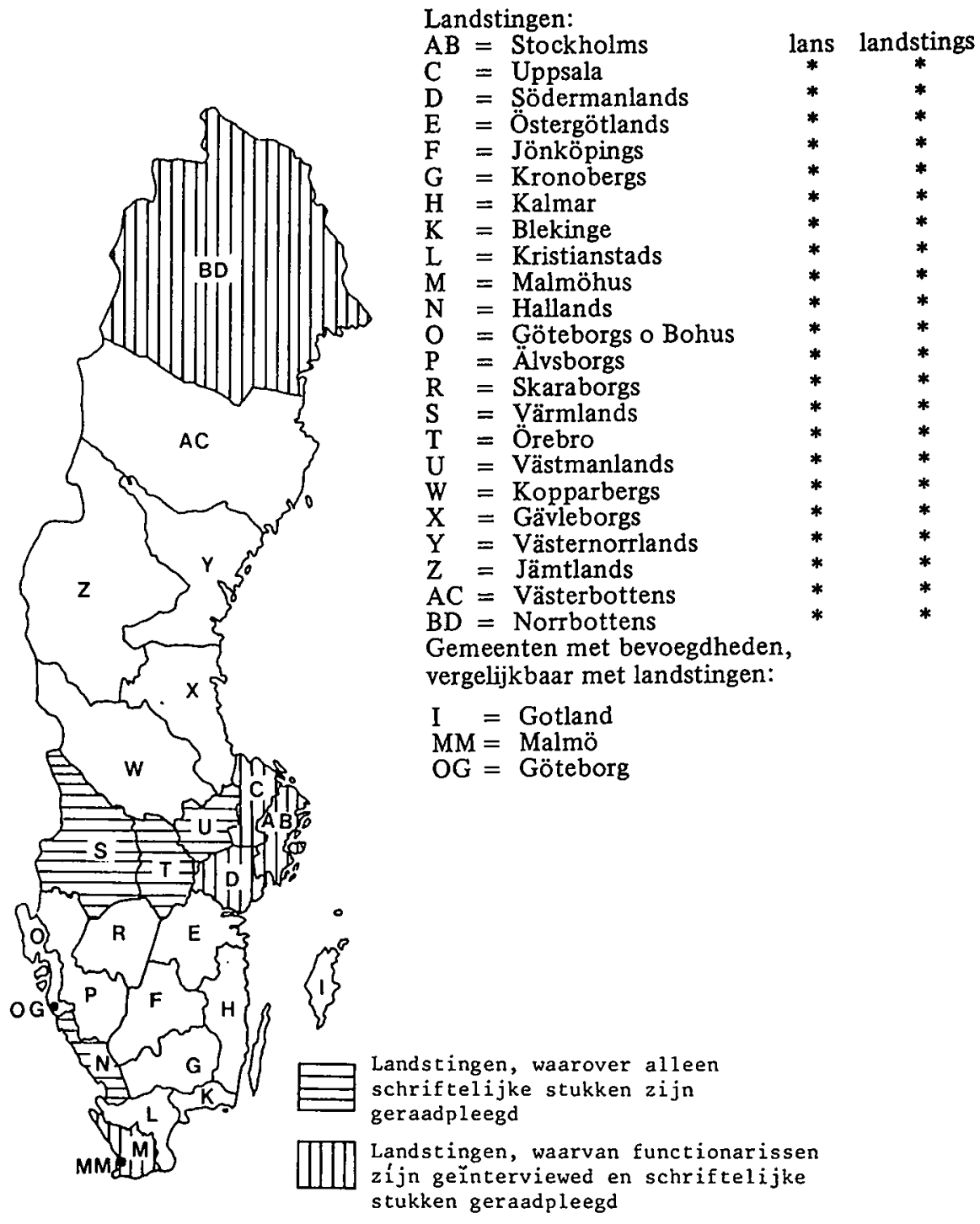


van de kosten van de National Health Service (NHS) per jaar hieraan uit (Lee Donaldson Associates, 203).

Onder regio voor gezondheidszorg wordt in deze studie verstaan een geografisch gebied, waarbinnen afstemming van de zorgverlening voor de meeste soorten zorg kan plaatsvinden. Met regionalisatie wordt in dit onderzoek bedoeld, zoals reeds in het voorwoord aangegeven, het geografisch, bestuurlijk indelen van de gezondheidszorg. Reeds hier zij vermeld, dat de regio's, waar de afstemming van de meeste soorten zorg plaatsvindt, in Engeland worden gevormd door de Area's en Districts en in Zweden door de Landstingen. De Engelse Regional Health Authorities (zie par. 3.2.) en de Zweedse ziekenhuisregio's (zie par. 4.2.) vallen buiten deze omschrijving. Deze hebben slechts betrekking op enkele zorgsoorten.

Voor het begrip planning wordt de omschrijving van het Department of Health and Social Security (DHSS) in Engeland overgenomen. Deze luidt vertaald: 'het beslissen, hoe het toekomstige patroon van aktiviteiten, produktiemiddelen en financiële middelen moet verschillen van het bestaande patroon; het onderkennen van de hiervoor benodigde veranderingen; het aangeven hoe deze veranderingen tot stand moeten worden gebracht en het toetsen of de ingevoerde veranderingen leiden tot het gewenste patroon". Strategische planning is gelijk aan lange termijnplanning en betreft een periode van tien à vijftien jaar. De operationele planning of middellange termijnplanning heeft betrekking op een periode van drie à vier jaar. In dit verband zij opgemerkt dat in dit boek de termen "beslissen", "besluiten" en "vaststellen" door elkaar worden gebruikt.

De planning van financiële middelen voor de periode van één jaar wordt in deze studie begroten ofwel budgetteren genoemd. Een open budget kan door een werkeenheid worden vergroot zonder toestemming van de financier. Bij een gesloten of taakstellend budget is deze toestemming wel vereist. Het begrip financiering wordt gereserveerd voor het beschikbaar stellen van financiële middelen. Budgetfinanciering is financiering van werkeenheden door een instantie op basis van door eerstgenoemde bij laatstgenoemde ingediende begrotingen. Financiering op basis van tarieven is het beschikbaar stellen van financiële middelen op basis van verrichte aktiviteiten. Indien een individuele zorgverlener zijn inkomsten verwerft op basis van tarieven, dan wordt deze in deze studie een voor eigen rekening werkende beroepsbeoefenaar genoemd. Onder regionale financiering wordt in deze studie verstaan het verwerven van financiële middelen door een regionaal orgaan om deze met een bepaalde eigen beleidsruimte beschikbaar te stellen aan de werkeenheden van de gezondheidszorg. In paragraaf 7.2.1. wordt van de omschrijvingen, die zijn afgeleid van de begrippen budget en financiering, nagegaan hoe deze zich verhouden tot die van andere auteurs.

Zoals in paragraaf 1.2. reeds aangegeven, is een werkeenheid een op zichzelf staand geheel, waar zorgverlening en besluitvorming plaatsvindt. Een werkeenheid, die een rechtspersoonlijkheid bezit, wordt in het onderzoek een instelling genoemd. Een verzameling gelijksoortige werkeenheden wordt in deze studie een voorziening genoemd, bijvoorbeeld de verpleeghuisvoorziening. Met het begrip funktie (bijvoeglijk naamwoord: funktioneel) wordt in deze studie de doelstelling van een bepaalde aktiviteit bedoeld: de poliklinische funktie van een ziekenhuis wordt uitgeoefend door poliklinische aktiviteiten. Een verzameling verschillende funkties en aktiviteiten wordt funktiepakket, respektievelijk aktiviteitenpakket genoemd: het funktiepakket van een ambulancedienst bestaat uit het zorgdragen voor het vervoer van zieken alsmede voor het vervoer van slachtoffers van verkeersongevallen.

Kortheidshalve wordt in het vervolg van dit boek met struktuur de formele struktuur bedoeld. Onder regionale strukturen worden de geregionaliseerde, formele be- 
sluitvormings- en organisatiestrukturen verstaan.

Tenslotte zij opgemerkt, dat de termen Engels en Brits verschillende betekenissen hebben. Groot Brittannië (bijvoeglijk naamwoord: Brits) bestaat uit Engeland (bijvoeglijk naamwoord: Engels), Wales, Schotland en Noord-Ierland. De eerste drie landen vormen samen het United Kingdom (UK) ofwel Verenigd Koninkrijk. (VK) 


\section{REGIONALISATIE EN FINANCIERING VAN DE ENGELSE GEZONDHEIDSZORG 1948-1974}

\subsection{ALGEMENE KENMERKEN VAN ENGELAND}

\subsubsection{Demografische en macro-economische kenmerken}

In tabel 2.1.1. worden enige kriteria aangegeven voor de bevolkingsopbouw en de macro-economische situatie in Engeland. In 1950 wonen in Engeland 41,4 mln. inwoners. In $1975 \mathrm{zijn}$ dat er 46,5 $\mathrm{mln}$. In 1990 worden er 50,9 mln. inwoners verwacht. De Engelse bevolking vergrijst: in 1950 is $10,9 \%$ van de bevolking 65 jaar of ouder. In 1975 bedraagt dit percentage 14,1, terwijl in 1990 een verdere stijging tot $14,8 \%$ wordt verwacht. In de afgelopen jaren daalde het geboortecijfer van 16,7 in 1950 naar 12,2 in 1975 . Verwacht wordt dat dit cijfer weer zal stijgen tot 16,1 in 1990 , omdat het aantal vrouwen van $15-44$ jaar in het totaal van de bevolking zal toenemen. Door de bevolkingstoename stijgt ook de bevolkingsdichtheid, namelijk van 320 inwoners per $\mathrm{km}^{2}$ in 1950 naar 360 in 1975 , tot naar verwachting 390 in 1991. Van de bevolking behoorde in $197424,8 \mathrm{mln}$. (46\%) tot de beroepsbevolking. Van deze $24,8 \mathrm{mln}$. werkten $2,8 \%$ in de landbouw, $42,3 \%$ in de industrie en $54,9 \%$

Tabel 2.1.1. Demografische en macro-economische kenmerken van Engeland

\begin{tabular}{|c|c|c|c|}
\hline & 1950 & 1975 & 1991 \\
\hline $\begin{array}{l}\text { - Bevolkingsomvang in mln. } \\
\text { - waarvan } 65 \text { jaar en ouder } \\
\text { - Aantal levend geborenen per } 1000 \text { inwoners } \\
\text { - Bevolkingsdichtheid (aantal inwoners per } \mathrm{km}^{2} \text { ) } \\
\text { - Beroepsbevolking in mln. arbeidskrachten } \\
\text { - waarvan landbouw en visserij } \\
\text { - } \quad \text { industrie } \\
\text { - overige sektoren } \\
\text { - Bruto Nationaal Produkt tegen marktprijzen (BNP) } \\
\text { in mld. } £ \\
\text { - BNP tegen constante prijzen }(1970=100) \\
\text { - Prijsindexcijfer voor de gezinsconsumptie }\end{array}$ & $\begin{array}{c}41,4 \\
16,7 \\
320\end{array}$ & $\begin{array}{r}46,5 \\
14,1 \\
12,2 \\
360 \\
24,8^{1} \\
2,8^{1} \\
42,3^{1} \\
54,9^{1} \\
94,0^{1} \\
110^{1} \\
208^{1}\end{array}$ & $\begin{array}{l}50,9 \\
14,8 \\
16,1 \\
390\end{array}$ \\
\hline
\end{tabular}

Bron: CSO (153 en 154), United Nations Organization (240).

1 Cijfer heeft betrekking op het Verenigd Koninkrijk.

Om een ontwikkeling in Engeland aan te geven worden in deze studie soms gegevens gebruikt die betrekking hebben op het gebied van Engeland en Wales tezamen of op het gehele Verenigd Koninkrijk. Van het eerste gebied woont $94 \%$ en van het tweede gebied $85 \%$ van de inwoners in Engeland. 
in de overige - voornamelijk dienstverlenende - sektoren.

In 1950 bedraagt het Bruto Nationaal Produkt tegen marktprijzen (BNP) $£ 11,7$ mld. In 1975 is dit ruim acht maal zo hoog, namelijk $£ 94,0$ mld. Dit houdt in een jaarlijkse stijging van het BNP van circa $9 \%$.

In constante prijzen gemeten bedraagt het indexcijfer $(1970=100)$ van het BNP in 195059 en in 1975110 . Dit houdt in een jaarlijkse groei van 2,5\%. Het prijsindexcijfer voor de gezinsconsumptie was in 1975 bijna vijf maal zo hoog als in 1950, hetgeen neerkomt op een jaarlijkse inflatie van $5 \%$.

Sinds 1973 maakt Engeland de zwaarste na-oorlogse recessie mee. Het indexcijfer voor het BNP tegen constante prijzen $(1970=100)$ daalde in 1974 en 1975 onder dat van 1973, zoals onderstaande staat laat zien.
1970100
$1973 \quad 113$
$1974 \quad 112$
1975110
$1976 \quad 113$

Hetzelfde beeld vertonen ook de bestedingen van de consumptiehuishoudingen en van de overheid als ook de totale investeringen (DHSS, 164, tabel 2.1.). De inflatie in deze jaren bedraagt $(1970=100)$ :
$1970\}$
1973
$9 \%$, gemiddeld
1974
$20 \%$
1975
$24 \%$
1976
$17 \%$
1977
$16 \%$
1978 (jan-aug) 10\% Bron: DHSS (164), tabel 2.5.

Het Engelse pond wordt in deze jaren steeds minder waard. De wisselkoers uitgedrukt in guldens per $£$ bedraagt vanaf 1970 :

$\begin{array}{ll}1970 & 8,66 \\ 1973 & 6,83 \\ 1974 & 6,29 \\ 1975 & 5,60 \\ 1976 & 4,78\end{array}$

$1976 \quad 4,78$ Bron: $C B S(22)$

De oorzaken en aanleiding van de economisch rampzalige jaren vanaf $1974 \mathrm{t} / \mathrm{m} 1976$ zijn de volgende (Vandewalle, 241):

Sinds 1975 heeft Groot-Brittannië bijna doorlopend betalingsbalansproblemen. De conservatieve regeringen van $1951 \mathrm{t} / \mathrm{m} 1964$ trachtten deze problemen te verhelpen door een stop-go politiek: bij grote betalingsbalanstekorten remden ze door allerlei restrictieve monetaire en fiscale maatregelen de binnenlandse bestedingen af en stimuleerden ze de exporten. Zodra het evenwicht op de betalingsbalans was hersteld, wakkerden deze regeringen de economische groei weer aan door een expansieve monetaire en fiscale politiek. Deze politiek leidde ertoe dat ondernemers slechts met grote omzichtigheid bij een economische groei overgingen tot nieuwe investeringen. Op lange termijn leidde deze situatie tot een veroudering van het Britse produktieapparaat en een geleidelijke inkrimping van de exportmogelijkheden (Vandewalle, 241 , p. 532). Van 1964 tot 1970 voerden de Labourregeringen van Wilson een politiek gericht op produktiviteitsstijgingen en economische groei. De investeringen namen echter weinig toe, omdat de winstbelastingen werden verhoogd. Van 1970 tot 28 februari 1974 slaagde Edward Heath er niet in de economische situatie van Engeland te verbeteren. Zijn beleid werd gekenmerkt door verlaagde inkomstenbelasting en verscherping van de concurrentie door toetreding van het VK tot de EG. Toen 
Heath in 1974, een maand voor de reorganisatie van de NHS aftrad, werd er in Engeland drie dagen per week gewerkt vanwege een staking bij de steenkolenmijnen en de elektriciteitsbedrijven. Wilson, aan het bewind gekomen na Heath, gaf de stakers hun zin, hetgeen leidde tot een prijsstijging over 1974 van $20 \%$ en over 1975 van $24 \%$. Het tekort op de betalingsbalans werd in 19744,5 maal zo groot als in 1973 (Vandewalle, 241). In juli 1975 sloot de regering een overeenkomst met de vakbeweging om te komen tot een loonmatiging. Deze leidde tot een aanmerkelijke daling van de inflatie in dat jaar, namelijk van $17 \%$ voor de eerste zes maanden naar $7 \%$ voor het tweede halfjaar.

Voor het financiële jaar 1976/1977 stelde de Britse regering voor de overheidsuitgaven te stabiliseren. $Z \mathrm{ij}$ wilde niet besnoeien om de werkgelegenheid niet in gevaar te brengen. Evenmin wilde zij de overheidsuitgaven verhogen, maar daarentegen de beschikbare economische groei gebruiken voor het verbeteren van de betalingsbalans alsmede het vergroten van de particuliere consumptie en de bedrijfsinvesteringen. De Britse regering stelde bovendien voor om die overheidsuitgaven prioriteit te geven die de produktiviteit en efficiency van het bedrijfsleven kunnen verbeteren (Chancellor of the Exchequer, 139).

Als anti-inflatie instrument introduceerde zij verder de cash-limits of cash-control. Deze houdt in, dat de verschillende departementen begroten tegen te verwachten lopende prijzen voor het betreffende financiële jaar. Indien de inflatie groter is dan verwacht, moet het volume van aktiviteiten worden ingekrompen en wordt het ambtelijk apparaat ingekrompen. De White Paper on Public Expenditure 1977 zegt het als volgt:

"In 1976-1977 cash-control will be applied to about three quarters of central Government voted expenditure (other than social security cash payment). The main exceptions will be those spending cannot be determined by the Government in the short term: this is why social security payments are being excluded, as well as, for example, expenditure on family practitioner services, agricultural support and some forms of regional assistance" (Chancellor of the Exchequer, 140).

De prijsstijgingen en de cash-limits voor 1976/1977 werden berekend in de veronderstelling, dat de anti-inflatie politiek van de Britse regering zou slagen. Indien de werkelijke inflatie aanmerkelijk groter zou zijn dan de verwachte, zouden de cashlimits evenwel opnieuw worden bekeken. Via dit beleid lukt het de regering de inflatie terug te brengen tot $17 \%$ (in 1976) en $16 \%$ (in 1977 en 1978). De werkloosheid steeg echter van 2,6\% in 1974 naar 4,2\% in 1975 en bedroeg in september 1978 $6,4 \%$ van de beroepsbevolking $(C S O, 151)$. Door de oliewinning uit de Noordzee lijken de toekomstvooruitzichten voor Engeland iets gunstiger te worden. Voor de komende jaren wordt een betalingsbalansoverschot verwacht en een daling van de werkloosheid. De groei van het BNP tegen constante prijzen tot 1981 wordt op $2 \%$ geschat (Chancellor of the Exchequer, 139, Vandewalle, 241).

\subsubsection{Gezondheidstoestand van de bevolking}

In tabel 2.1.2. worden enige kriteria aangegeven voor de somatische gezondheidstoestand van de bevolking. In 1975 is de perinatale sterfte gehalveerd ten opzichte van 1950. De gemiddelde verwachte levensduur van mannen bij geboorte neemt met drie jaar toe van 66,3 jaar in 1950 tot 69,5 jaar in 1975 . De verlenging van deze levensduur van vrouwen bedraagt 4,7 jaar (van 71,0 naar 75,7 jaar).

De mortaliteit per 100.000 inwoners neemt enigszins af van 1234 naar 1184 sterftegevallen. De verdeling van de mortaliteit naar doodsoorzaak verschilt in 1975 van die in 1950. In het eerstgenoemde jaar sterft $73 \%$ aan de twee belangrijkste doodsoorzaken, te weten kwaadaardige nieuwvormingen en hart- en vaatziekten. In 1950 
is dat percentage $53 \%$. Sterfte an infectie-ziekten wordt over de onderzoeksperiode teruggebracht van 61 naar 6 per 100.000 inwoners. Over andere aspecten van de gezondheidstoestand zoals zorgbehoeften en psycho-sociaal welbevinden is weinig in statistieken en literatuur te vinden. Geconstateerd wordt in een aantal publikaties een toenemende zorgbehoefte ten gevolge van de veroudering van de bevolking (DHSS, 170 en Care of the elderly in Britain, 138).

Tabel 2.1.2. Gezondheidstoestand van de bevolking van Engeland (incl. Wales)

\begin{tabular}{l|c|c}
\hline Gemiddelde verwachte levensduur bij geboorte & 1950 & 1975 \\
\hline - mannen & 66,3 & 69,5 \\
- vrouwen & 71,0 & 75,7 \\
Perinatale sterfte per 1000 geborenen & 38,0 & 19,3 \\
Mortaliteit per 100.000 inwoners & 1234 & 1184 \\
Alle doodsoorzaken & & \\
infektieziekten & 61 & 6 \\
kwaadaardige nieuwvormingen & 438 & 251 \\
hart- en vaatziekten & 525 & 609 \\
overige ziekten & 318 \\
\hline
\end{tabular}

Bron: $\operatorname{CSO}(151,152,164)$.

\subsubsection{Organisatie van het overheidsbestel}

Het Britse parlementaire stelsel komt in grote lijnen overeen met het Nederlandse stelsel. Te onderscheiden zijn de regering, het House of Commons (vergelijk Tweede Kamer) en het House of Lords (vergelijk Eerste Kamer). Het Britse begrotingsjaar loopt van 1 april van het ene jaar tot en met 31 maart van het jaar daarna: zo ook het financiële jaar van de NHS. Eind december begin januari, voorafgaande aan het financiële jaar, publiceert de regering een regeringsnota, waarin de inkomsten en uitgaven voor de komende vier jaren worden begroot. Deze regeringsnota voor het jaar 1976 - 1977 heet Public Expenditure to 1980 - 1981 en wordt populair genoemd de White Paper on Public Expenditure. Deze White Paper, te vergelijken met de Nederlandse Miljoenennota, wordt eerst in zijn geheel in het House of Commons besproken. Deze algemene ronde is te vergelijken met de Algemene Financiële Beschouwingen in Nederland en wordt genoemd de Discussion on the budgets. Daarna kiest het House's Select Committee on Expenditure onderwerpen uit deze White Paper voor verdere behandeling in subcommissies van het House of Commons. Deze subcommissies rapporteren hierover dan aan het House of Commons. Het parlement gaat akkoord met de begroting van elk departement door de stemmingen, de Annual Votes. De regering wordt hiermee gemachtigd uitgaven te doen voor het eerste jaar waarop de White Paper on Public Expenditure betrekking heeft. De begrotingen voor de overige drie jaren worden ter kennisneming aangenomen.

Het komt regelmatig voor, dat ministers na de "Votes" terugkomen naar het parlement met het verzoek de begroting te verhogen. In de White Paper on Public Expenditure wordt met deze supplementary requirements reeds rekening gehouden. In de maanden februari/maart, voorafgaande aan het financiële jaar, dat op 1 april begint, publiceert de regering de Supply Estimates, een nadere detaillering van de programma's, waarvoor begrotingsgelden worden gevraagd. Deze Supply Estimates zijn minder belangrijk dan de White Paper on Public Expenditures. Ze komen aan de orde in het parlement bij de behandeling van de begrotingen van de ver- 
schillende departementen. In de maand januari na het financiële jaar dat eindigt op 31 maart, publiceert de regering de Appropriation Account, waarin de gedane uitgaven van dat financiële jaar worden verantwoord. De White Paper on Public Expenditure wordt voorbereid op ambtelijk niveau, door bilaterale besprekingen tussen de Minister van Financiën - de Chancellor of the Exchequer - en de vakministers, alsmede binnen het kabinet. Een belangrijk rapport dat aan de White Paper on Public Expenditure voorafgaat is het (PESC) - Report, te weten het Public Expenditure Survey Committee Report. Dit rapport is te vergelijken met de nota Ongewijzigd beleid in de Nederlandse verhoudingen. Het wordt opgesteld door de Principal Finance Officers van de vakdepartementen en het ministerie van financiën. Op basis van het PESC-Report vinden de beraadslagingen over de nieuwe begroting binnen het kabinet plaats. Het PESC-Report komt uit in juni voorafgaande aan het financiële jaar, waar het over gaat. Als verschilpunt met de Nederlandse praktijk is te vermelden dat de troonrede - the Queen's Speech - niet bij het indienen van de begroting wordt gehouden, maar in september. De inhoud van deze troonrede is niet financieel van aard. De Britse wetgeving in het algemeen komt in grote lijnen overeen met de Nederlandse. Een voorbeeld van de procesgang van een wetsontwerp wordt gegeven in paragraaf 3.1., waarin de voorbereiding van de reorganisatie van de NHS wordt beschreven. Een aantal Britse uitdrukkingen wordt hieronder vergeleken met in Nederland gangbare begrippen.

De term White Paper is bestemd voor regeringsnota's. Deze zijn als zodanig te herkennen door de letters CMND, afkorting van Command, en een cijfercode. Een Consultative Document, meestal genoemd Green Paper, is het beste te vergelijken met het Voorontwerp van wet in de Nederlandse verhoudingen. Een Bill is een wetsontwerp, en een Act een door het parlement aangenomen wet. Aan belangrijke nieuwe wetten of wetswijzigingen kunnen werkzaamheden van een Royal Commission vooraf gaan. Zo'n krooncommissie onderzoekt grondig een bepaald vraagstuk. Zij sluit haar onderzoek af met een rapport met aanbevelingen voor het te voeren beleid. De commissie bestaat uit leden die op persoonlijke titel op grond van verdiensten in het verleden door de regering zijn benoemd. Ze representeren geen groeperingen en/of politieke partijen. De rapportage van een Royal Commission is gebaseerd op Evidences, speciaal voor deze commissie geformuleerde standpunten van alle mogelijke betrokkenen bij het vraagstuk. Meestal zijn deze Evidences openbaar en worden ze ongevraagd aan de Royal Commission kenbaar gemaakt. Naast de hierboven beschreven centrale overheid kent Engeland ook lokale overheden, namelijk counties, districts, boroughs en de Greater London Council. Sinds 1974 is de struktuur als volgt. Er zijn 45 counties. Zij betreffen het gebied buiten Greater London en variëren in bevolking van 110.000 (Isle of Wight) tot $2,8 \mathrm{mln}$. (West Midlands). De stedelijke counties zijn verdeeld in districts met een omvang van meestal meer dan 200.000 inwoners, hetgeen neerkomt op gemiddeld zes districts per county. De plattelands counties kennen districts in de orde van grootte van 60.000 tot 100.000 inwoners, hetgeen neerkomt op zeven districts per county. Londen en omstreken - Greater London - met 7,3 mln. inwoners is ingedeeld in 32 London Boroughs en the City of London. De boroughs zijn te vergelijken met de counties.

De taken van de counties en districts betreffen de ruimtelijke ordening (beiden), verkeerszaken (alleen counties), openbaar vervoer (counties), onderwijs, maatschappelijke dienstverlening (in steden: districts, elders counties), volkshuisvesting (districts), politie en brandweer (counties). Op te merken is, dat onder de maatschappelijke dienstverlening in Engeland een aantal aktiviteiten valt, die in Nederland tot de gezondheidszorg worden gerekend. Te noemen zijn instellingen voor lichamelijk ge- 
handicapten, zwakzinnigen, verpleeghuisbehoeftige patiënten en demente bejaarden. Voorzieningen voor deze groepen patiënten kunnen in Engeland zowel vallen onder local authorities als onder NHS-authorities. Waar nodig zal hiermee in de komende paragrafen rekening worden gehouden. Zoals in paragraaf 1.3.3. vermeld, wordt in deze studie onder de Engelse gezondheidszorg de National Health Service verstaan. Indien in de komende paragrafen over aktiviteiten van de local authorities wordt gesproken dan wordt dat expliciet vermeld. Het aandeel van de lokale overheden in de totale belastingen bedraagt in $197515 \%$. De uitkeringen van het rijk vormen de belangrijkste inkomsten van de counties en de districts. Eens in de vier jaar worden de besturen van de counties en districts via algemene verkiezingen gekozen. De lokale overheden zijn tegelijk met de NHS gereorganiseerd op 1 april 1974 . Het aantal districts en counties is toen verminderd (zie uitgebreid Local Government in Britain, 206).

\subsection{ORGANISATIESTRUKTUUR VAN DE GEZONDHEIDSZORG 1948 - 1974}

Aan de invoering van de NHS op 5 juli 1948 gingen in de jaren 1937 - 1948 drie belangrijke gebeurtenissen vooraf, te weten een inventarisatie van de Britse gezondheidszorg in de jaren $1937-1939$, het opzetten van de Emergency Medical Service voor oorlogsslachtoffers in 1939, en het verschijnen van het Beveridge-Report in 1942. Van 1937 tot 1939 maakte een groep van 200 onderzoekers in opdracht van de regering een inventarisatie van de Britse gezondheidszorg. Deze groep - Political and Economical Planning (PEP) Group - beschreef de gezondheidszorg in die jaren als een van een "Bewildering variety of agences" $(P E P, 220)$. In 1939 kende het Verenigd Koninkrijk namelijk twee totaal gescheiden groepen ziekenhuizen, de local authority-ziekenhuizen en de particuliere (voluntary) ziekenhuizen. Deze twee verschilden in hun oorsprong, ontwikkeling, personeelsbezetting en financiën. Er waren in 1939 in Engeland en Wales 3000 ziekenhuizen, waarvan eenderde particuliere, met ongeveer de helft van het totaal aantal bedden in intramurale instellingen. Op basis van de inventarisatie kwam de PEP tot de aanbeveling dat de samenwerking tussen local authority en particuliere ziekenhuizen zou moeten worden gebaseerd op een regionale autoriteit met bevoegdheden over een groot geografisch gebied $(P E P, 220)$. De tweede belangrijke gebeurtenis was de invoering in 1939 van de Emergency Medical Service (EMS). Deze regeling - een oorlogsmaatregel - gaf de Minister van Gezondheidszorg voor het eerst in de geschiedenis de verantwoordelijkheid voor een deel van de gezondheidszorg, namelijk de behandeling in ziekenhuizen van oorlogsslachtoffers. Gedurende de oorlog groeide deze EMS uit tot een nationale ziekenhuiszorg met vele noodhospitalen, bloedtransfusiecentra en ongevallenpoliklinieken. De derde gebeurtenis is het verschijnen van het Beveridge-Report (236), dat verstrekkende aanbevelingen deed, op basis waarvan de Engelse na-oorlogse welvaartstaat zich zou gaan ontwikkelen. In dit rapport werd een allesomvattende comprehensive gezondheidszorg bepleit: een medische zorg, beschikbaar voor iedereen, zowel thuis als in het ziekenhuis, verleend door huisartsen, specialisten, tandartsen, verpleegkundigen en vroedvrouwen (Social Insurance and Allied Services, 236). In $1946 \mathrm{kwam}$ onder leiding van de Minister of Health, Aneurin Bevan, na White Papers in 1944 en 1945 de National Health Service Act tot stand, die leidde tot de invoering van de NHS op 5 juli 1948.

De NHS-Act beoogde iedere inwoner van Engeland de gezondheidszorg vrij ter beschikking te stellen, "ongeacht zijn of haar financiële middelen, leeftijd, geslacht, beroep, woongebied of verzekeringskeuring" (NHS-Act 1946, 210). Drie grote her- 
vormingen waren het gevolg van de invoering van de NHS:

1. een fundamentele wijziging van het betaalsysteem. In de jaren veertig bestond in Engeland vooral het systeem van betaling per verrichting. Er waren weinig particuliere verzekeringsinstellingen terwijl sociale verzekeringen slechts bestonden voor huisartsenzorg voor de lagere inkomensgroepen (National Insurance Act, 1911).

2. een volledige reorganisatie van het ziekenhuiswezen. De NHS-Act van 1946 droeg de eigendommen van 3000 ziekenhuizen over aan de staat. Hierdoor ontstond een nationaal ziekenhuissysteem met een regionale planning. Hierbij werden alle tot dat moment elkaar beconcurrerende ziekenhuizen samengebracht in 330 groepen, geleid door Hospital Management Committees (HMC's).

3. een uitbreiding van de wijkgezondheidszorg. Huisartsen, farmaceutische- en tandartsenhulp, alsmede het voorschrijven van brillen werden vanaf 1948 voornamelijk uit belastingen betaald.

De organisatiestruktuur van de NHS van 1948 tot 1974 wordt in grafiek 2.2. weergegeven. Te onderscheiden zijn:

1. het Department of Health and Social Security (DHSS), verantwoordelijk voor het algemene, nationale gezondheidsbeleid op het gebied van ziekenhuizen, medische specialisten, Public Health Laboratory Service, Blood Transfusion Service, en onderzoek betreffende preventie, diagnostiek en behandeling van ziekten. Verder heeft het DHSS een verantwoordelijkheid voor de diensten van huisartsen en van lokale overheden, die echter beide in een onafhankelijke positie staan ten opzichte van het DHSS.

2. Regional Hospital Board (RHB). Engeland en Wales werden op basis van de fakulteiten der geneeskunde - medical schools - ingedeeld in aanvankelijk veertien, later vijftien regio's (zie grafiek 2.4.3.1).

Aan het hoofd van iedere regio staat een RHB. Deze Board is samengesteld uit de door de Minister benoemde voorzitter en afgevaardigden van de medische fakulteit, alsmede uit vertegenwoordigers van artsenorganisaties. Verder doet deze Board de planning van de ziekenhuizen en de specialistische zorg en controleert deze. Hij heeft de supervisie van de hieronder te bespreken Hospital Management Committees, benoemt gedeeltelijk de medische staven van de ziekenhuizen en beheert de bloedtransfusiedienst.

3. de Hospital Management Committee (HMC). Engeland en Wales telden van 1948 tot 1974 circa 330 HMC's, die vooral uit leken-bestuurders bestonden. De besturen van de particuliere ziekenhuizen vonden in deze HMC's een zekere compensatie voor het verlies van invloed.

De HMC's waren verantwoordelijk voor de leiding van de ziekenhuizen.

4. de Board of Governors. In Engeland en Wales viel elk van de 36 academische ziekenhuizen - teaching hospitals - onder de bevoegdheid van een Board of Governors (BoG). Deze Board was rechtstreeks verantwoordelijk aan de Minister. $Z_{\mathrm{ij}}$ verzorgde zowel de planning van het teaching hospital als de dagelijkse gang van zaken.

5. de Executive Council (EC). Het beleidsorgaan voor diensten van Independent Contractors, te weten huisartsen, tandartsen, opticiens en apothekers. Er waren er 34 . Ze waren samengesteld uit vertegenwoordigers van de diverse betrokkenen. $\mathrm{Zij}$ moesten de planning en distributie van de diensten van de Independent Contractors verzorgen, sloten kontrakten met hen en fungeerden als klachtenbureau.

6. de Local Health Authority (LHA) behartigde het beheer en de planning van ge- 
zondheidscentra, wijkverpleging, zuigelingenzorg en van het ambulancevervoer. Het aantal LHA's bedroeg 175. Een LHA was samengesteld uit leden van de County Council casu quo Borough Council.

Indien we afzien van een paar kleine uitzonderingen is in de NHS-struktuur een driedeling te herkennen tripartite structure:

hospital services, onder verantwoordelijkheid van de RHB's en de BoG's, community services, onder verantwoordelijkheid van LHA's en de family practitioner services, onder verantwoordelijkheid van de EC's.

Deze struktuur bleef van 1948 tot 1974 vrijwel onveranderd. Ze was het compromis van de voorstellen van verschillende belangengroepen in de gezondheidszorg (zie voor de beschrijving van de totstandkoming van de NHS: Roelens, 227, Levitt, 205, Allen, 121 en Blanpain, 128).

Grafiek 2.2. Organisatiestruktuur NHS 1948-1974

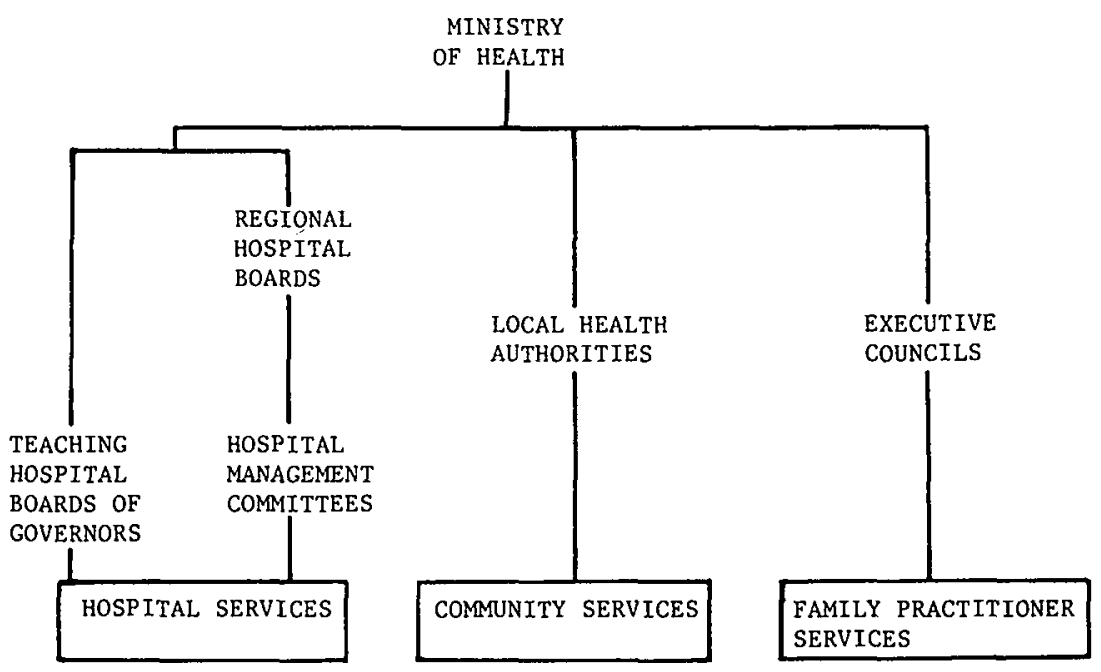

Bron: Levitt (205)

\subsection{BESLUITVORMINGSSTRUKTUUR VAN DE GEZONDHEIDSZORG 1948 -} 1974

Kenmerkend voor de formele besluitvorming van de NHS van $1948-1974$ is, dat per groep van voorzieningen deze beslissingen door dezelfde instanties worden genomen. De beslissingen over de maatschappelijke gezondheidszorg worden in de periode 1948 - 1974 genomen door de local authorities. Deze zorg werd gefinancierd uit de belastingen van deze overheden.

De huisartsen, apothekers, tandartsen en opticiens - gezamenlijk de family practitioners - beschouwen zichzelf als "independant contractors". Niet in loondienst zijnde leveren ze hun zorg op contractbasis aan de NHS. Ze worden betaald met deels financiële middelen van het Rijk en deels eigen bijdragen van de patiënt. De 
huisartsen worden betaald gedeeltelijk op abonnementstarief en gedeeltelijk op verrichtingsbasis. In 1973-1974 verwierven zij 40\% van hun inkomen uit het abonnementstarief (Accounts 1973-1974, NHS Acts 1946-1968, 119). De overige independant contractors verwerven hun inkomsten voornamelijk per verrichting. Ten aanzien van de huisartsen wordt door de Executive Committee een vestigingsbeleid gehanteerd. Hiertoe is Engeland verdeeld in 200 gebieden. Deze gebieden worden naar het aantal inwoners per huisarts geklassificeerd in vijf kategorieën. Deze variëren van een "restricted area", waar een zich vestigende huisarts een premie voor inrichtings- en aanloopkosten van zijn praktijk ontvangt.

De beslissingen over de academische ziekenhuizen worden genomen door de Board of Governors. Voor de overige intramurale instellingen worden de korte termijnbeslissingen door de Hospital Management Committee en de lange termijnbeslissingen door de Regional Hospital Board genomen. Tussen de academische en de overige intramurale instellingen bestaat een verschil, dat in paragraaf 2.4.2. van belang zal blijken te zijn, namelijk, dat de eerstgenoemden een rechtstreeks kontakt hebben met het DHSS in tegenstelling tot de laatstgenoemden. Voor het aantrekken van artsen en de aanschaf van dure apparatuur heeft de BoG toestemming nodig van het DHSS. De HMC heeft deze hiervoor nodig van de RHB. Over de overige medewerkers en apparatuur beslissen de BoG en de HMC zelf. Voor nieuwbouw van ziekenhuizen hebben beiden toestemming nodig van het DHSS.

De medisch specialisten van de academische ziekenhuizen zijn in loondienst bij de BoG en van de overige ziekenhuizen bij de RHB. Voor hun werk buiten NHS-verband zijn de specialisten in staat een kleine klinische en poliklinische praktijk te houden, te weten maximaal $2 / 11$ van een full-time baan van elf dagdelen. Voor de aanschaf van apparatuur en werkruimte alsmede voor het aantrekken van medewerkers heeft de medisch specialist toestemming nodig van de HMC casu quo de BoG. Deze laatsten beoordelen, of deze bestedingen passen binnen de begroting, die goedgekeurd is door de RHB (DHSS) en op basis waarvan ze periodiek uitkeringen ontvangen ter dekking van de kosten. De RHB kent een dergelijk stelsel van budgetfinanciering door het DHSS, dat op zijn beurt zijn beschikbare financiële middelen vastgesteld ziet door het Rijk, te weten regering en parlement. Het DHSS ontvangt zijn financiële middelen zowel van de Chancellor of the Exchequer - 's rijks schatkist - als uit sociale verzekeringspremies. Deze laatste geldstroom wordt ook door het Rijk vastgesteld en bedroeg in het financiële jaar 1973-1974 tien procent van die van de eerstgenoemde. In grafiek 2.3.1. worden de financiële relaties tussen de medisch specialist en het rijk schematisch weergegeven. Alleen de relaties via de RHB en de HMC zijn vermeld. Bij de academische ziekenhuizen moet de lezer deze instanties vervangen door de BoG. Onder infrastruktuur wordt verstaan het geheel van medewerkers, werkruimte en apparatuur ten behoeve van de medisch specialist. Een $\leftarrow$ betekent: financiële middelen worden beschikbaar gesteld door.

Grafiek 2.3.1. Financiële relaties medisch specialist en het rijk

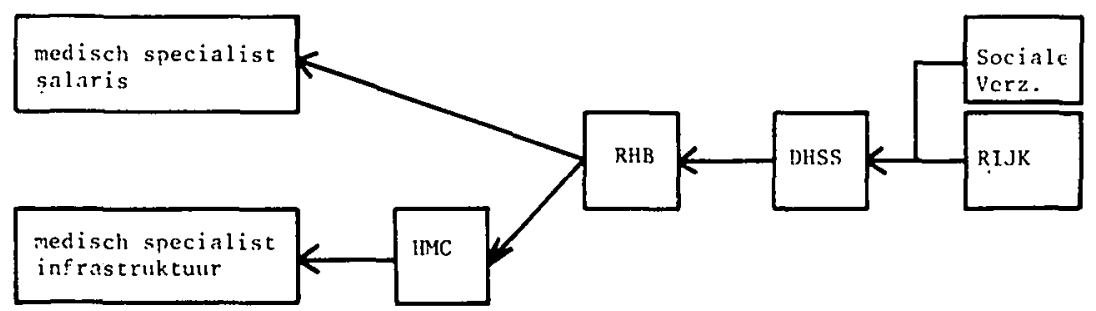


De aktiviteiten van de arts - diagnose- en therapievaststelling, medicijnen voorschrijven, verwijzing - worden door hemzelf in overleg met de individuele patiënt vastgesteld. Omdat een arts voor zijn werk vrijwel altijd medewerkers, apparatuur en huisvestingsruimte nodig heeft - waarvoor hij aanvragen moet indienen bij de desbetreffende instanties - worden zijn aktiviteiten wel indirekt door de instanties beinvloed. Als basis voor de verdeling van de financiële middelen over de BoG's en de RHB's hanteerde het DHSS de begroting van het lopende jaar. Normaliter verleende het DHSS toestemming deze begroting te verhogen met een percentage vanwege de inflatie en met een percentage voor het ontwikkelen van bepaalde nieuwe aktiviteiten. Dit laatste werd in de interviews van dit onderzoek wel "the icing on the cake" genoemd. Sinds het financiële jaar 1971-1972 t/m 1973-1974 wordt getracht de uitkeringen van het DHSS aan de RHB's te baseren op het aantal inwoners en het aantal bedden. In deze jaren werden de volgende toewijzingskriteria gehanteerd:

1. bevolking. Deze wordt gewogen met de nationale opname-coëfficiënt per leeftijd en geslacht van de ziekenhuizen. Tevens vinden er aanpassingen plaats voor

a. netto im- of export van patiënten behandeld buiten de eigen regio;

b. klinische onderwijsfunkties van de RHB-ziekenhuizen;

c. het aandeel van de bevolking behandeld in academische ziekenhuizen.

2. bedden. Het gemiddeld aantal dagelijks bezette bedden en polikliniekbezoeken

Grafiek 2.3.2. Door het DHSS gehanteerde formule voor toewijzing van financiële middelen naar Engelse RHB's in de periode 1971-'72 - 1973-'74.

Gegeven: Nationaal beschikbaar bedrag voor RHB's $=a=£ 1000 \mathrm{mln}$.

Nationale bevolkingsomvang

Gemiddelde kosten per bed

$=\mathrm{b}=50 \mathrm{mln}$

$=\mathrm{c}=£ 3000$

Gemiddelde kosten per behandelde

klinische patiënt

Uitkering aan RHB in voorafgaand jaar

$=\mathrm{d}=£ 100$

RHB-bevolking

RHB- aantal bedden

Aantal behandelde klinische patiënten

$=\mathrm{e}=£ 150 \mathrm{mln}$.

$=\mathrm{f}=5 \mathrm{mln}$.

$=\mathrm{g}=40.000$

$=\mathrm{h}=1,1 \mathrm{mln}$.

Berekening: Uitkering op basis van bevolkingsomvang $=\frac{\mathrm{f}}{\mathrm{b}} \times \mathrm{a}=\mathrm{k}$

$=\frac{5 \mathrm{mln}}{50 \mathrm{~min} .} \times 1000 \mathrm{mln} .=£ 100 \mathrm{mln}$.

Uitkering op basis van aantal bedden $=\mathrm{g} \times \mathrm{c}=1$

$=40.000 \times £ 3000=£ 120 \mathrm{mln}$.

Uitkering op basis van behandelde patiënten $=\mathrm{h} \times \mathrm{d}=\mathrm{m}$

$=1,1 \mathrm{mln} . \times £ 100=£ 110 \mathrm{mln}$.

Gemiddelde uitkering $=0,5 \mathrm{k}+0,25 \mathrm{l}+0,25 \mathrm{~m}=\mathrm{n}$

$=0,5 \times £ 100 \mathrm{mln} .+0,25 \times £ 120+0,25 \times £ \cdot 110 \mathrm{mln} .=107,5 \mathrm{mln}$.

Uitkering in het verleden $=e=£ 150 \mathrm{mln}$.

Verschil formule-uitkering en historische uitkering $=\mathrm{n}-\mathrm{e}=£ 107,5 \mathrm{mln} .-£ 150$ $\operatorname{mln} .=£ 42,5 \mathrm{mln}$.

Uitkering gedurende het eerste jaar van het toepassen van de formule $=$ $£ 150 \mathrm{mln} .-10 \% \cdot £ 42,5 \mathrm{mln} .=£ 145,75 \mathrm{mln}$. 
per specialisme wordt statistisch gewogen met de gemiddelde kosten voor het gehele land.

3. aantallen behandelde patiënten (cases). Klinische- en poliklinische patiënten worden statistisch gewogen met de nationale gemiddelde kosten.

Aan de faktor "bevolking" wordt een dubbel gewicht toegekend ten opzichte van de "bedden" en "cases".

De hier aangegeven formule zou grote gevolgen hebben: sommige RHB's zouden in enkele jaren veel moeten bezuinigen, andere sterk groeien. Het DHSS wilde daarom deze gevolgen over tien jaren uitspreiden. Iedere regio kreeg in het financiële jaar 1971-1972 een uitkering op basis van de historische kosten plus een landelijk stijgingspercentage, vermeerderd of verminderd met $10 \%$ van het verschil van deze uitkering en de op basis van de formule toe te wijzen gelden. Met ieder jaar herberekeningen zou dan in tien jaar tijd de formule ingevoerd kunnen zijn. Een uitzondering op deze toerekeningsformule werd gemaakt voor de gevolgen van geïnvesteerd kapitaal op de lopende rekening. De gevolgen kunnen betreffen de kosten van installatie, huisvesting, onderhoud en bediening van de apparatuur. In 1971 werden hiervoor aparte fondsen toegekend (Revenue Consequence of Capital Schemes, RCCS). Het plan was deze fondsen vanaf 1971 in zeven jaar te laten verdwijnen, waarna RHB's de gevolgen van nieuwe investeringen dan binnen hun eigen lopende rekeningen zouden moèten opvangen.

Grafiek 2.3.2. bevat een rekenvoorbeeld voor de hierboven aangegeven formule (ontleend aan P.A. West, 245).

\subsection{DOELSTELLINGEN GEZONDHEIDSZORG}

\subsubsection{Niveau en kwaliteit handhaven}

Tabel 2.4.1. geeft een overzicht van ontwikkeling van de aktiviteiten van de NHS over de periode 1949-1974. Uit deze tabel is het volgende af te lezen:

- over de periode 1954-1974 daalt het aantal huisartsen per 1000 inwoners van 0,51 naar 0,46 . Het aantal wijkverpleegkundigen nam toe van 0,23 per 1000 inwoners in 1949 naar 0,6 in 1974.

- het aantal poliklinische consulten in algemene ziekenhuizen per 1000 inwoners is in $197413 \%$ hoger dan in 1949.

- de opnamen in alle intramurale instellingen nemen toe, zowel in totaal als per 1000 inwoners.

- de gemiddelde ligduur in algemene ziekenhuizen neemt af van 15,5 naar 10,4 dagen. De bezettingsgraad van de intramurale instellingen varieert in 1974 van $72 \%$ tot $91 \%$.

- het aantal bedden van de instellingen neemt zowel in totaal als per 1000 inwoners af. Alleen voor verpleeghuizen neemt het aantal toe van 50.000 naar 57.000 .

- de gemiddelde omvang van ziekenhuizen incl. verpleeghuizen neemt toe van 122 naar 142 bedden. Van de overige instellingen daalt de omvang van 637 naar 395 bedden.

- het aantal arbeidskrachten van de NHS is in 1974 ruim 700.000, dat wil zeggen bijna het dubbele van dat in 1949. Het aantal verpleegkundigen, wijkverpleegkundigen en medische specialisten wordt gekenmerkt door een relatieve stijging in dezelfde orde van grootte. De groei van het aantal huisartsen en tandartsen is aanmerkelijk minder.

Als verklaring voor deze aktiviteitengroei worden door verschillende auteurs vraag- 
1949

Totaal
1974

per 1000 inw. Totaal per 1000 inw.

Aantal poliklinische consulten alg. ziekenhuizen Aantal opnamen in:

- algemene ziekenhuizen

- psychiatrische ziekenhuizen ${ }^{2}$

- verpleeghuizen

- zwakzinnigeninrichtingen $^{2}$

Gemiddelde ligduur in algemene ziekenhuizen Gemiddelde bezettings-

$24,7 \mathrm{mln} . \quad 602,4$

$2,7 \mathrm{mln}$.

$15,5 \mathrm{dgn}$.

graad in:

- algemene ziekenhuizen

- psy chiatrische ziekenhuizen

- verpleeghuizen

- zwakzinnigeninrichtingen

Aantal bedden $(x 1000)$

in:

- algemene ziekenhuizen

- psychiatrische ziekenhuizen ${ }^{2}$

- verpleeghuizen

- zwakzinnigeninrichtingen $^{2}$

Totaal aantal bedden in bovengenoemde intramurale instellingen

Gemiddelde grootte (in bedden) van:

- algemene ziekenhuizen incl. verpleeghuizen

- psychiatrische ziekenhuizen incl. zwakzinnigeninrichtingen

Aantal arbeidskrachten

NHS

waarvan huisartsen

wijkverpleegkun-

digen

medisch specia-

listen

verpleegkundigen, incl. leerlingen en incl. wijkverpl. tandartsen
72.000

78.000

65,9

1,8

1,9

$72 \%$

$87 \%$

$91 \%$

$91 \%$

$\begin{array}{rrrr}199.000 & 4,8 & 180.000 & 3,9 \\ 180.000 & 4,4 & 160.000 & 2,2 \\ 50.000 & 1,2 & 57.000 & 1,2 \\ & & 55.000 & 1,2\end{array}$

$429.000 \quad 10,4$

$402.000 \quad 8,5$
142

395

ca. 380.000

$21.165^{3}$

9,3

$0,51^{3}$

$9.529 \quad 0,23$

$11.735 \quad 0,29$

149.726

3,7

9.495

0,23
706.849

21.531

15,2

$27.646 \quad 0,60$

$25.618 \quad 0,55$

Bron: DHSS (164), OHE (215). 
1 Deze tabel loopt van 1949 - 1974 vanwege de stichtings- en reorganisatiedatum juli 1948 resp. april 1974.

2 Bedden in zwakzinnigeninrichtingen staan in 1949 vermeld onder de psychiatrische ziekenhuizen.

31959.

aanbod modellen gehanteerd (Cooper, 148, Culyer, 159). Als oorzaken aan de vraagzijde worden genoemd de veroudering van de bevolking en een veranderd ziektegedrag. Aan de aanbodzijde wordt gewezen op de groei van de medisch-technische mogelijkheden en van het Bruto Nationaal Produkt als faktoren die de aktiviteitenomvang hebben doen toenemen (zie ook Godber, 190).

Te betwijfelen is of het niveau van de verleende zorg in alle opzichten de behoeften van de bevolking dekt. Deze twijfel is gebaseerd op de volgende gegevens. In 1975 bevond zich circa $25 \%$ van de bedden van intramurale instellingen in gebouwen van na 1948. Met name gebouwen voor verpleeghuizen, psychiatrische ziekenhuizen, zwakzinnigeninrichtingen zijn vaak oud (Brown, 133). Verder zijn er volgens de beroepsorganisaties te weinig tandartsen, ziekenhuis- en wijkverpleegkundigen, health visitors* en vroedvrouwen, een en ander gemeten met maatstaven van officiële rapporten $(B M A, 129)$.

Op grond van deze gegevens wordt in Engeland gesproken van de onderfinanciering van de NHS. Over de toegankelijkheid van de zorgverlening zijn de volgende punten op te merken. De gemiddelde praktijk van huisartsen telt in 19742170 patiënten. Voor wijkverpleegkundigen bedraagt deze in dat jaar 1680 patiënten. Voor de patiënten zijn financiële drempels aanwezig voor het gebruik van medicijnen en dergelijke. Sinds 1949 bedraagt het aantal patiënten op de wachtlijst van algemene ziekenhuizen per 31 december circa een half miljoen personen $(D H S S, 164)$. Gelet op de bezettingsgraad van de ziekenhuizen ( $72 \%$ ) ligt dit vooral aan het gebrek aan mankracht. Gemiddeld wordt er in Engeland in 197514 weken op een chirurgische ingreep gewacht (Zie Culyer, 158 en Cooper, 148). De invloed van het financieringsstelsel op het niveau en de kwaliteit van de zorgverlening wordt besproken in de volgende paragraaf.

\subsubsection{Afremming kostengroei}

In 1973-1974 zijn de kosten van de NHS zeven maal zo hoog als in 1949-1950 (zie tabel 2.4.2.). Uitgedrukt als percentage van het BNP stijgen deze kosten van 4,0\% naar $4,9 \%$. Het aandeel van de intramurale zorg groeit van $55 \%$ in $1949-1950$ naar $67 \%$ in 1973-1974. De overige voorzieningen nemen in het laatste jaar een kleiner aandeel in dan in het eerste. Van de kosten van de NHS wordt in het financiële jaar 1973-1974 $81 \%$ door het Rijk, $7 \%$ door de lokale overheid, $8 \%$ uit sociale verzekeringen en $3 \%$ uit eigen bijdragen van patiënten betaald (DHSS, 164). Als verklaringen voor de kostenstijging zijn te noemen de aktiviteitenontwikkeling (zie par. 2.4.1.) en de inflatie (zie par. 2.1.1.).

* Verantwoordelijk voor zuigelingen- en kleuterbureau's. 


\begin{tabular}{l|c|c}
\hline & $1949-1950$ & $1973-1974$ \\
\hline Totale kosten in mln. $£$ & $446 \quad(=100 \%)$ & $3055 \quad(=100 \%)$ \\
intramurale zorg & $55 \%$ & $67 \%$ \\
huisartsenzorg & $11 \%$ & $7 \%$ \\
tandartsenzorg & $11 \%$ & $5 \%$ \\
medicijnengebruik & $14 \%$ & $10 \%$ \\
maatschappelijke gezondheidszorg & $8 \%$ & $6 \%$ \\
overige kosten & $1 \%$ & $5 \%$ \\
Totale kosten NHS als \% van het BNP & $4,0 \%$ & $4,9 \%$ \\
\hline
\end{tabular}

Bron: DHSS (164), OHE (215).

* Gekozen is voor gegevens van het Verenigd Koninkrijk om een aansluiting met het Bruto Nationaal Produkt mogelijk te maken. In 1973-'74 bedroegen de kosten van de NHS in Engeland 84\% van die van het gehele V.K.

Van de kosten van de NHS wordt zoals gezegd $81 \%$ gefinancierd uit de Rijksfinanciën. Dit houdt in dat de begroting van de NHS jaarlijks als onderdeel van de DHSSbegroting ter discussie staat bij het voorbereiden en opstellen van de Rijksbegroting door de Britse regering en het Britse parlement. Hierbij wordt de DHSS-begroting afgewogen tegen die van andere departementen.

Er zijn verschillende argumenten die er op wijzen, dat dit afwegingsproces de ontwikkeling van de NHS heeft afgeremd. Te noemen zijn de volgende punten:

1. in het voorbereidingsproces van de rijksbegroting zijn verschillende stadia aan te geven waarin de DHSS-begroting wordt afgewogen tegen de totale rijksbegroting en tegen de begrotingen van andere departementen (zie par. 2.1.3.). In deze stadia moeten de DHSS-belangen steeds opnieuw worden verdedigd. Crossman, oudminister of health, geeft in zijn boek Inside View aan, dat het hierbij vaak om harde onderhandelingen gaat (Crossman, 156, zie ook David Owen, 218 en Enoch Powell, 184). In een dergelijk proces is het zeer waarschijnlijk, dat het DHSS regelmatig bepaalde wensen moet inleveren.

2. in interviews met funktionarissen van health districts in Wessex Region en in de N.W. Thames Region werd erop gewezen, dat voor uitbreiding van het aantal arbeidsplaatsen, de aanschaf van apparatuur, (ver)nieuwbouw door de HMC steeds toestemming nodig was van de RHB. Deze uitbreidingen moesten gerealiseerd worden binnen de toegestane uitkeringen voor dat jaar. Voor het verdelen van deze uitkeringen deden individuele werkeenheden voorstellen aan de HMC en deze laatste aan de RHB. Op analoge wijze als bij de rijksbegroting worden deze wensen in het voorbereidingsproces van de begroting tegen elkaar afgewogen. Hiervoor zijn gedetailleerde procedures ontwikkeld, waarbij zo veel mogelijk betrokkenen worden gehoord voordat de HMC of RHB een beslissing neemt. In interviews werd meegedeeld, dat een arts, die een bepaald apparaat of een medewerker nodig heeft, zijn wens soms door dertig commissies moet loodsen, voordat een en ander gerealiseerd wordt. Een dergelijk besluitvormingsproces leidt tot een weloverwogen prioriteitenstelling. Verder sneuvelen in dit afwegingsproces wensen vanwege een onvoldoende argumentatie, of door de vervulling van een overeenkomstige wens bij een andere werkeenheid.

3. een voorbeeld van de remmende invloed van het afwegingsproces op de ontwik- 
keling van de totale kosten is het volgende uit het begin van de jaren vijftig. Toen de NHS in 1944 werd voorbereid, verwachtte Lord Beveridge dat de totale kosten van de gezondheidszorg zouden dalen op de langere duur door de bevordering van de preventieve en de wijkgezondheidszorg (Social Insurance and Allied Services, 236). In de Bill van 1946 werden de bruto kosten voor het eerste jaar van de NHS in Engeland en Wales geschat op $£ 152 \mathrm{mln}$. In de eerste negen maanden van het bestaan van de NHS was dit bedrag echter reeds $£ 276 \mathrm{mln}$. groot. In het financiële jaar 1949-1950 bedroegen de kosten $£ 446 \mathrm{mln}$. (CSO, 152).

Vanwege deze tegenvallende kostenstijgingen stelde de Minister van Financiën in 1951 een limiet aan de kosten van de NHS van $£ 400 \mathrm{mln}$. Tevens voerde de regering een eigen bijdrage in voor tandartsen- en oogartsenzorg. De Minister van Gezondheidszorg en pleitbezorger van de NHS Aneurin Bevan was het hier niet mee eens en trad at.

Tot 1956 bleef de houding van de regering en het parlement kritisch ten opzichte van de kostenstijgingen van de NHS. In deze jaren daalden de kosten van de NHS als percentage van het BNP van 3,9\% in 1951 naar 3,7\% in $1957(O H E, 215)$. Expliciet werd bij de overheidsinvesteringen de hoogste prioriteit gelegd bij woningbouw en scholenbouw. Er werd slechts toestemming verleend door het DHSS voor de nieuwbouw van zes ziekenhuizen, hoewel in $194845 \%$ stamde uit de periode vóór 1891 (Levitt, 205, p. 156). Het Guillebaud-report, genoemd naar de voorzitter van een Rijkscommissie met de opdracht de kosten van de NHS te onderzoeken, veranderde deze kritische houding. Het gaf aan dat de kostenstijgingen in de voorafgaande jaren het gevolg waren van inflatie, bevolkingstoename en een grotere zorgconsumptie. Het noemde de NHS verder efficiënt en pleitte voor meer nieuwbouw van ziekenhuizen. Het Guillebaud-report beinvloedde de mening van de regering en het parlement, waardoor vanaf 1956 de kosten van de NHS sneller konden groeien dan vóór dat jaar (groei 1951 -1955: 5,2\%, groei 1956 - 1959, 8,1\% p.j.) (zie uitgebreid: Allen, 121).

4. een tweede voorbeeld gaat over het Hospital Plan - 1962 (DHSS, 160). In dit plan werd het District General Hospital (DGH) geïntroduceerd, 600 à 800 bedden groot, bestemd voor een bevolking van 100.000 à 150.000 inwoners. Het plan voorzag in de nieuwbouw van 90 dergelijke ziekenhuizen vóór 1975. In totaal zou door nieuwbouw en vernieuwbouw circa 750 van de 2800 ziekenhuizen in Engeland en Wales worden vervangen. Het Hospital Plan werd aangenomen, hetgeen in de jaren na 1962 leidde tot een snellere groei van de kosten van de NHS dan in de jaren ervoor (groei 1959-1961: 5,6\% en 1963-1965: 11,3\% p.j.).

5 . tenslotte is het volgende punt aan te voeren: de medische specialisten zijn van mening dat $\mathrm{zij}$ in hun aktiviteiten worden geremd door de formele financiële besluitvormingsstruktuur. In augustus 1974 hield de British Medical Association $(B M A)$ ter voorbereiding van haar standpuntbepaling over particuliere praktijken een enquête onder de 16.000 Engelse specialisten. Van hen antwoordden bijna 10.000 specialisten. $45 \%$ Was van mening onvoldoende huisvesting en apparatuur tot zijn beschikking te hebben. Vier op de tien artsen meenden over onvoldoende medewerkers te beschikken $(B M A, 131)$.

Uit de beschrijving van de begrotingsprocedures sub 1 en 2 en de voorbeelden sub 3, 4 en 5 is af te leiden, dat opvattingen van de Britse regering van grote invloed zijn op de hoogte van de totale kosten van de NHS. Deze invloed werd uitgeoefend door het bestaan van een afwegingsproces in het financieringsstelsel. Het lijkt zeer aannemelijk, dat hierdoor de ontwikkeling van de aktiviteiten en kosten van de NHS zijn afgeremd en slechts toenamen bij een expliciete, voorafgaande besluitvorming. Deze 
afremming is zo sterk geweest, dat thans in Engeland gesproken wordt van een onderfinanciering van de NHS.

Het financieringsstelsel heeft behalve het bovengenoemde effekt ook een gevolg voor de ontwikkeling van de Engelse academische ziekenhuizen gehad. Er is te wijzen op een grotere groei van academische ziekenhuizen dan die van algemene, acute ziekenhuizen. De kosten van eerstgenoemden groeiden in de periode $1960-1970$ $16,2 \%$ per jaar en die van laatstgenoemden $12,2 \%$ per jaar $(O H E, 215)$ Gemeten in investeringen per jaar blijken de eerstgenoemden over dezelfde periode met $46,1 \%$ per jaar te zijn gegroeid en de laatstgenoemden met 27,9\% per jaar. De verklaring voor deze groeiverschillen is volgens vele geinterviewden te vinden in de rechtstreekse financiering van de academische ziekenhuizen door het departement. Eerst in 1970 wordt hun positie minder gunstig door publicaties over de spreiding van voorzieningen over Engeland (zie par. 2.4.3.).

De Londense gebieden, waarin zich de meeste Engelse academische ziekenhuizen bevinden, blijken dan betere en meer voorzieningen te hebben dan overige Engelse regio's. Ten gevolge van deze publicaties kreeg het verkleinen van de geografische spreiding van voorzieningen meer aandacht in het beleid en werden de (Londense) academische ziekenhuizen minder bevoorrecht. Van 1971-1972 t/m 1973-1974 groeiden de kosten van deze ziekenhuizen met $8,8 \%$ en die van overige intramurale instellingen met $11 \%$.

\subsubsection{Evenwichtige geografische spreiding}

In grafiek 2.4.3.1. worden de kosten van het jaar 1971 - 1972 van de verschillende vormen van gezondheidszorg van de NHS vermeld per 1000 inwoners en per regio. De

Grafiek 2.4.3.1. Kosten NHS per 1000 inwoners per regio in 1971-1972
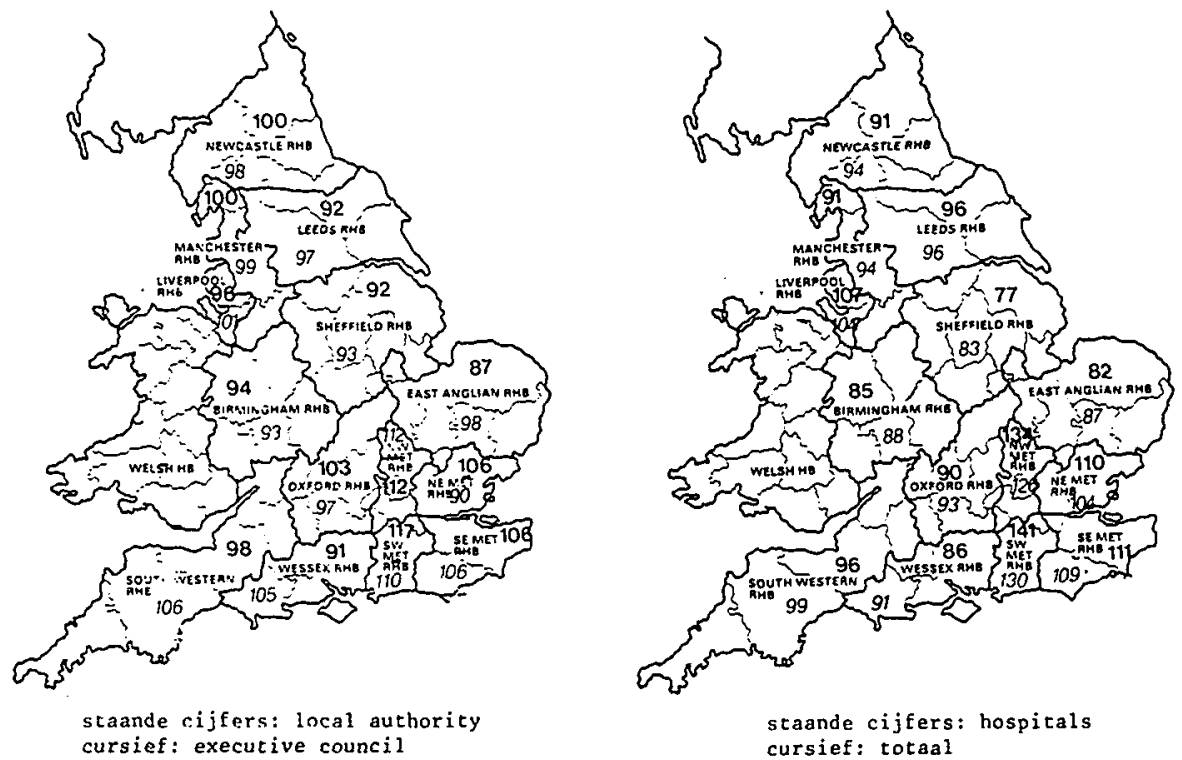

Bron: Noyce (188). 
regionale verschillen zijn groter voor de ziekenhuizen (variatiecoëfficiënt $=$ v.c. $=$ $18 \%$ ) dan voor de totale kosten (v.c. $=14,2 \%$ ), de local authorities (v.c. $=8,1 \%$ ) en Executive Councils (v.c. $=6,9 \%$ ). De kosten van de local authorities en de executive councils vertonen een positieve samenhang met de kosten van de ziekenhuizen. In grafiek 2.4.3.2. worden de kosten van de intramurale zorg inclusief academische ziekenhuizen over de periode 1955-1970 per regio en per hoofd van de bevolking weergegeven.

Er blijken grote en continue verschillen tussen de regio's te bestaan in de kosten van ziekenhuiszorg per hoofd van de bevolking. De grootste bestedingen komen voor in de Londense regio's. Birmingham, East-Anglia en Sheffield geven $80 \%$ van het landelijk gemiddelde uit. Uit grafiek 2.4 .3 blijkt, dat deze verschillen in de loop der jaren wél geringer zijn geworden: South Western, Welsh, Leeds, Manchester en New Castle zijn gegroeid naar het nationale gemiddelde. Oxford en Wessex weken in 1970 méér af van het gemiddelde dan in 1955 en 1960. De spreiding van de huisartsen over Engeland is en blijft ongelijk. Cooper en Culyer vermelden dat in $195252 \%$

Grafiek 2.4.3.2. Kosten intramurale instellingen in 1955-1956 en 1969-1970 per 1000 inwoners en per RHB (Engeland en Wales $=100 \%$ )

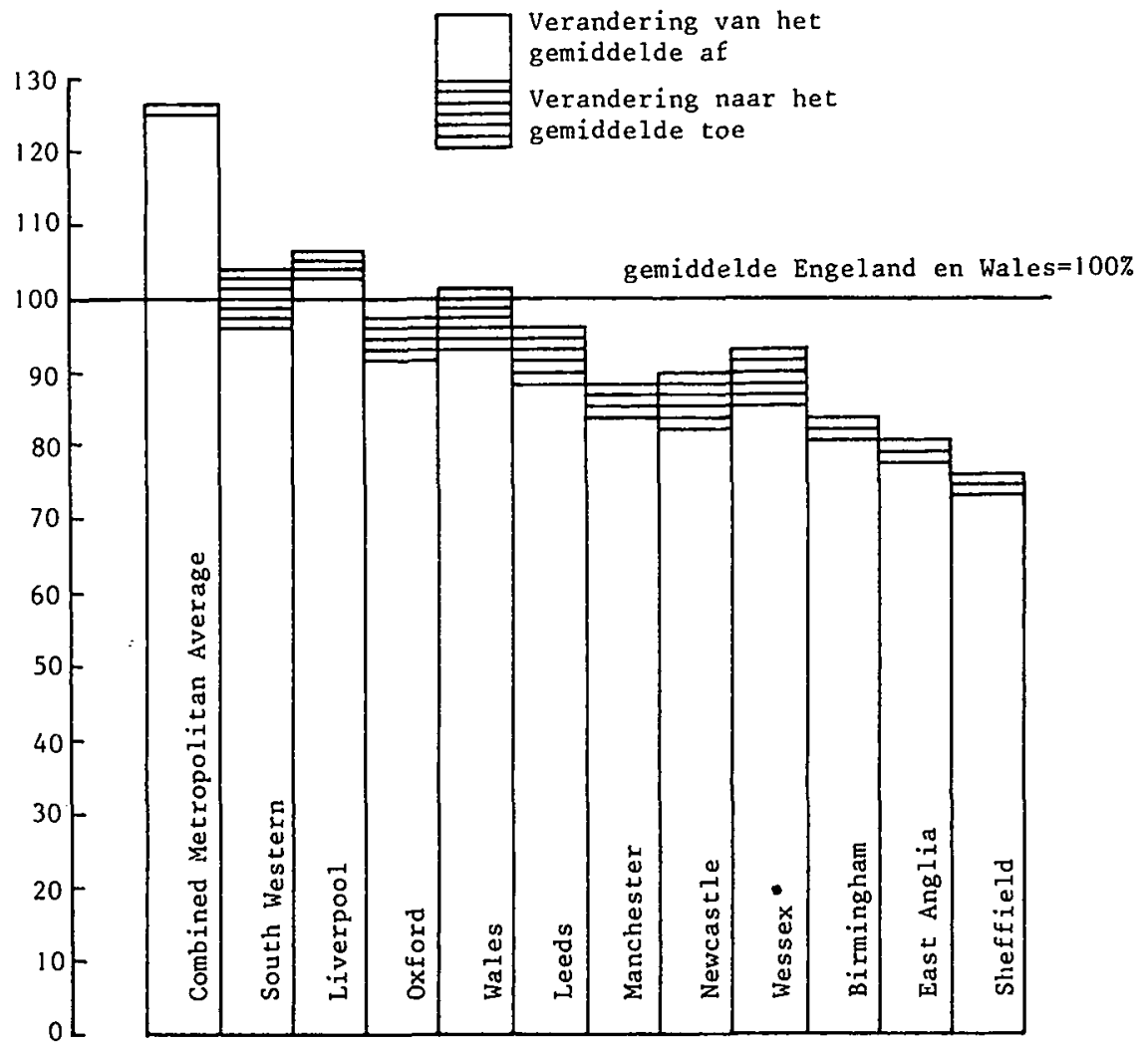

Bron: Griffiths (165)

* 1959-1960 
van de Engelse bevolking woonde in gebieden met een gemiddelde huisartsenpraktijk boven de 2500 patiënten (under-doctored areas). Met behulp van een negatief vestigingsbeleid voor huisartsen in gebieden met praktijken kleiner dan 2500 patiënten, konden nieuwe huisartsen zich slechts in de under-doctored areas vestigen. Dit leidde ertoe dat het percentage van $52 \%$ in 1952 daalde tot $17 \%$ in 1962 . Toen evenwel het aantal huisartsen minder groeide en zelfs daalde, steeg dit percentage weer tot 36\% in 1970 (Cooper en Culyer, 149, zie uitvoerig: Butler, 135 en 136).

Cooper en Culyer hanteren in een onderzoek in 197231 indices om regionale verschillen per hoofd van de bevolking te meten in mankracht en verrichtingen van de verschillende vormen van gezondheidszorg. Gemeten worden de produktieregio's. Er blijken grote regionale verschillen te bestaan in bijvoorbeeld aantallen specialisten, ziekenhuisbedden en opnamen per 1000 inwoners (Cooper en Culyer, 149 en 150). In hetzelfde jaar toont Alan Maynard regionale verschillen aan voor de psychiatrische ziekenhuizen (Maynard, 208). Noyce, Cook en Butler vermelden verschillen in spreiding van respectievelijk de maatschappelijke gezondheidszorg, tandartsen en huisartsen (Noyce, 214, Cook, 147, Butler, 136). Uit deze onderzoeken blijkt in het algemeen dat een regio met hoge kosten voor gezondheidszorg per hoofd van de bevolking aan alle vormen van gezondheidszorg veel besteedt (zie Cooper, 148, Noyce, 214). Dit is evenwel niet altijd het geval. De Thames Regions en de Liverpool Region hebben minder geriatrische en verpleeghuisbedden per 1000 bejaarden dan het Engelse gemiddelde, terwijl dit andersom geldt voor de weinig bestedende regio's Sheffield, East Anglia en Birmingham (DHSS, 164).

Verschillende personen van meer dan een regio en van verschillende wetenschappelijke instituten zijn in het kader van dit onderzoek gevraagd naar de oorzaken van het grotendeels in stand blijven van deze regionale verschillen gedurende de periode 1948 - 1970. Studies naar de oorzaken bleken niet verricht te zijn. Enige aannemelijke verklaringen, die elkaar aanvullen zijn de volgende:

1. gedurende de periode 1948 - 1970 waren andere doelstellingen voor de NHS belangrijker. De veranderingen in het betaalsysteem, de reorganisatie van het ziekenhuismanagement en de uitbreiding van de eerstelijn leverden zulke grote vraagstukken op, dat alle beleid hierop gericht was.

2. het toewijzen van financiële middelen op basis van de begroting van het afgelopen jaar en een percentage voor de "icing on the cake" heeft het in 1948 bestaande patroon in grote lijnen in stand gehouden.

3. een relatieve herverdeling is eenvoudiger te bereiken naarmate de begroting van het DHSS sneller groeit. De regio's met een achterstand kunnen dan inlopen, terwijl de "rijke regio's" niet gekort worden maar langzaam groeien. Indien de DHSS-begroting langzaam groeit - zoals het geval was in de jaren 1948 - 1974 is een herverdeling moeilijker doordat de rijkere regio's moeten inleveren, hetgeen bij deze op verzet zal stuiten.

De discussies en publicaties over de regionale verschillen leidden tot de introductie van de formuletoewijzing van financiële middelen van het DHSS naar de RHB's. De formule hiervoor staat beschreven in paragraaf 2.3. Door deze formuletoewijzing neemt de spreiding in kosten per hoofd van de bevolking en per RHB enigszins af in de jaren na 1970-1971 (variatie-coëfficiënt 1970-1971:: 15,1\%; v.c. 1972-1973: $14,4 \%$; en v.c. $1973-1974: 8,2 \%)$.

\subsubsection{Integratie zorgverlening}

In haar proefschrift "Van desintegratie naar integratie in de Engelse gezondheidsdienst" beschrijft $A$. Roelens (121) hoe de tripartite structure van de NHS een in- 
tegraal beleid in de jaren 1948-1974 belemmerde. $\mathrm{Zij}$ noemt de volgende voorbeelden van desintegratie van de zorgverlening:

- ontslag van herstellenden uit acute ziekenhuizen wordt vaak bemoeilijkt doordat een opname in een gemeentelijk revalidatiecentrum niet mogelijk is. Toch blijkt, dat in deze laatste de bedden vaak onbezet blijven (p. 44).

- de huisarts moet vaak met meer dan één local health authority onderhandelen, indien hij voor zijn patiënt een wijkverpleegkundige of maatschappelijk werker nodig heeft (p. 45).

- de huisarts is niet in staat zijn patiënten in het ziekenhuis te ontmoeten. Hij voelt zich daar niet welkom (p. 46).

- de planning van de aktiviteiten van de RHB is zeer moeilijk, doordat de academische ziekenhuizen buiten de jurisdictie van de RHB's vallen (p. 48).

- niet universitaire ziekenhuizen hebben moeite jonge artsen aan te trekken, doordat hun wetenschappelijk peil onvoldoende is. De beste artsen blijven binnen de academische centra werken.

- de bestuurlijke coördinaties in de vorm van overlegcommissies bestaande uit leden van de verschillende instanties werken niet. De commissies bestaan uit hoge beleidsfunktionarissen, die elkaar een of tweemaal per jaar ontmoeten. De werkers uit het veld ontmoeten elkaar echter niet (p. 37).

- bij de start van de NHS werd beoogd de zorgverlening in de eerstelijn vooral te doen plaatsvinden vanuit gezondheidscentra. In 1965 zijn er echter pas 23 centra tot stand gekomen, ofwel één à twee per jaar. Aan deze geringe groei ligt ten grondslag het gebrek aan financiële middelen voor de bouw van deze centra, als ook de weerstand van de huisartsen tegen een controle van de local health authorities tegen deze centra. Eerst na 1965 worden deze bezwaren minder: in 1972 zijn er 365 en vele honderden in staat van wording (p. 40).

Verdere voorbeelden van desintegratie worden genoemd door David Owen (217) in zijn boek "A Unified Health Service". Met behulp van case-histories geeft hij gebreken aan in de relaties tussen ziekenhuis-huisarts en maatschappelijke dienstverlening, tussen wijkgezondheidszorg en zwakzinnigeninrichtingen en tussen intramurale en ambulante geestelijke gezondheidszorg.

Om het gebrek aan samenhang in de zorgverlening tegen te gaan worden in de jaren zestig vele pleidooien gehouden voor eenheid van bestuur voor de werkeenheden van gezondheidszorg binnen een regio. Onder eenheid van bestuur is dan te verstaan het nemen van besluiten over aktiviteiten, financiële middelen, arbeidsplaatsen, kapitaalgoederen en organisatiestruktuur door één en dezelfde instantie. Het eerste belangrijke pleidooi om binnen de NHS tot eenheid van bestuur te komen, kwam in 1963 van vertegenwoordigers van de medische professie.

In het zogenaamde Porritt-report on a Health Service for the Nation bepleitten zij eenheid van bestuur op lokaal niveau (Medical Services Review Committee, 209). Dit rapport werd door de regering aanvankelijk slecht ontvangen (Godber, 190). Vier jaren later, in 1967, startte de regering een uitgebreid onderzoek naar de gewenste struktuur voor de komende twintig jaar. Dit onderzoek leidde in juli 1968 tot de publicatie van The Administrative Structure of Medical and Related.Services in England and Wales (DHSS, 174) later bekend geworden als de First Green Paper. In dit rapport wordt eveneens eenheid van bestuur bepleit op lokaal niveau: veertig à vijftig Areas Boards zouden de bestaande autoriteiten gaan vervangen. De grenzen zouden moeten samenvallen met die van de lokale overheid. Na deze Green Paper ontstaan brede maatschappelijke discussies. Er verschijnen verscheidene rapporten van nationale instanties, die alle eenheid van bestuur bepleiten op lokaal ni- 
veau, soms voor gezondheidszorg en maatschappelijke dienstverlening tezamen. Te noemen zijn het Seebohm-report, het Report of the Royal Commission on Local Government in England en de Second Green Paper on the NHS. Goede samenvattingen van deze rapporten en kommentaren erop zijn vermeld in de dissertatie van Roelens en in diverse beschrijvingen van de geschiedenis van de NHS (Levitt, 205, Godber, 191, Roelens, 121). Op basis van deze brede maatschappelijke discussie zal uiteindelijk op 1 april 1974 de NHS worden gereorganiseerd.

\subsubsection{Vergroten betrokkenheid van patiënten en medewerkers*}

"Patients and their hospitals" en "Psychiatric hospitals viewed by their patients" zijn twee publicaties van Winifred Raphael (247 en 248), uitgegeven door het King's Edward's Hospital Fund for London. In het eerste rapport worden meningen over het verblijf in een algemeen ziekenhuis weergegeven van meer dan 10.000 patiënten uit 68 algemene ziekenhuizen in het Verenigd Koninkrijk. In de tweede studie geven 2148 psychiatrische patiënten uit negen psychiatrische instellingen hun mening over hun verblijf aldaar. Beide onderzoeken werden verricht aan het begin van de jaren zeventig en zijn tot nu toe de enige die in deze omvang verricht zijn. Hieronder wordt op basis van de beide publicaties ingegaan op de satisfactie van patiënten.

In antwoord op de vraag "Do you like your stay here apart from being away from home?" antwoordden de patiënten als volgt:

\begin{tabular}{l|l|l}
\hline & $\begin{array}{l}\text { algemene ziekenhuis- } \\
\text { patiënten }\end{array}$ & $\begin{array}{l}\text { psychiatrische } \\
\text { patiënten }\end{array}$ \\
\hline very much & $56 \%$ & $18 \%$ \\
in most way & $38 \%$ & $36 \%$ \\
only fairly well & $5 \%$ & $23 \%$ \\
no & $1 \%$ & $17 \%$ \\
\hline
\end{tabular}

Uit deze antwoorden blijkt, dat in de algemene ziekenhuizen de patiënten voor het overgrote deel (94\%) tevreden zijn. Voor de psychiatrische patiënten gaat dat slechts op voor iets meer dan de helft $(54 \%)$.

Over de verschillende aspekten van de zorgverlening in de algemene ziekenhuizen was 3 à $14 \%$ van de patiënten ontevreden, zoals uit onderstaande vragen en antwoorden blijkt (alleen ja-en neen-antwoorden waren mogelijk):

- Had you long enough notice of admission to hospital?

- Was your reception satisfactory when you first reached the hospital? $3 \%$

- Did the nurses come quickly by day?

by night?

$3 \%$

$2 \%$

- Were you told enough about your illness and your treatment?

* De satisfactie en inspraak van NHS-medewerkers en de inspraak van patiënten komt in par. 3.4.5. aan de orde. 
De psychiatrische patiënten waren minder tevreden over verschillende aspekten van de zorgverlening, zoals uit onderstaande vragen en antwoorden blijkt:

Do you see the doctors enough?

Do they tell you enough?

Do you get sufficient care from the nurses?

Do you feel reasonably free?

Over verschillende huisvestingsaspekten bleken 5 à $8 \%$ van de patiënten in de algemene ziekenhuizen ontevreden te zijn. Alleen de sanitaire voorzieningen zijn hierop een uitzondering (40\%). De desbetreffende vragen en negatieve antwoorden worden hieronder vermeld:

NO

Were your bed and bedding comfortable?

Had you enough privacy in the ward?

Were there enough bathrooms?

Were the meals satisfactory?

- breakfast

- dinner/lunch

- supper

Bij de psychiatrische patiënten is minder tevredenheid:

Is the ward generally quiet enough?

Do you get enough privacy in the ward, bathroom and so on?

In satisfactie-onderzoeken kan het verschijnsel van de sociale wenselijkheid een rol spelen bij het beantwoorden van de vragen. Als voorzichtige conclusie is daarom alleen te stellen, dat de meeste patiënten in het algemene ziekenhuis tevreden zijn over de meeste aspekten van de zorgverlening en de huisvesting. Voor de psychiatrische patiënten geldt dit voor een geringer deel. 


\section{REGIONALISATIE EN FINANCIERING VAN DE ENGELSE GEZONDHEIDSZORG SINDS 1974}

\subsection{INLEIDING}

Na de First Green Paper (zie par. 2.4.4.) volgde in februari 1970 de Second Green Paper on the Future of the NHS (DHSS, 175). In deze Green Paper wordt het aantal Area Boards vergroot van vijftig tot negentig en worden veertien health regions geintroduceerd. Beide Green Papers waren van de hand van socialistische Secretaries of State. In juni $1970 \mathrm{kwam}$ de Conservative Party aan het bewind. De nieuwe Secretary of State, Sir Keith Joseph, publiceerde in mei 1971 een nieuw Consultative Document, (DHSS, 177), waar alleen belanghebbende groeperingen op konden reageren. In deze nota worden de taken van de regions en areas alsmede de patiënteninspraak nader geregeld. Verder worden er veel detailvoorstellen van de Second Green Paper veranderd. In augustus 1972 publiceerde de conservatieve regering de White Paper "NHS Reorganized: England" (DHSS, 177). Gevolgd in november 1972 door de NHS Bill. (DHSS, 167). Na de parlementaire debatten werd deze Bill op 5 juli 1973, op de dag af 25 jaar na de start van de NHS, door de Koningin getekend, waarmee de NHS-Reorganization Act een feit werd. Als startdatum voor de reorganisatie werd gekozen 1 april 1974. Een maand voor deze datum viel de conservatieve regering. De grotendeels door deze regering voorbereide reorganisatie zou moeten worden uitgevoerd door een socialistisch kabinet.

\subsection{ORGANISATIESTRUKTUUR VAN DE NHS VANAF 1 APRIL 1974}

Kenmerkend voor de nieuwe organisatiestruktuur van de NHS is de geintegreerde geografische organisatie. Vanaf 1 april 1974 vallen alle voorzieningen binnen een bepaald geografisch gebied onder de verantwoordelijkheid van één autoriteit. Deze autoriteit is tevens verantwoordelijk voor de zorgverlening aan de inwoners binnen haar gebied. In grafiek 3.2.A. wordt de nieuwe struktuur schematisch weergegeven. Te onderscheiden zijn vier management niveau's:

1. het Ministerie van Gezondheidszorg en Sociale Zekerheid (Department of Health and Social Security: DHSS).

2. 14 Regional Health Authorities (RHA) met $\pm 31 / 2 \mathrm{mln}$. inwoners (zie grafiek 3.2.B.).

3. 90 Area Health Authorities (AHA) met $\pm 1 / 2 \mathrm{mln}$. inwoners (zie grafiek 1.3.2.1.).

4. 205 distrikten (districts) met \pm 250.000 inwoners.

Het bestuur van het district wordt gevormd door het District Management Team (DMT). Het is verantwoordelijk voor het adekwaat funktioneren van het gezondheidszorgsysteem in het district. Het verdeelt de geldmiddelen over de verschillende werkeenheden, uitgezonderd de Family Practitioners (zie hieronder). Het team is over de uitvoering van het beleid verantwoording schuldig aan de AHA, het coördinerend orgaan tussen de districten en de RHA. Van de 90 AHA's coördineren 54 


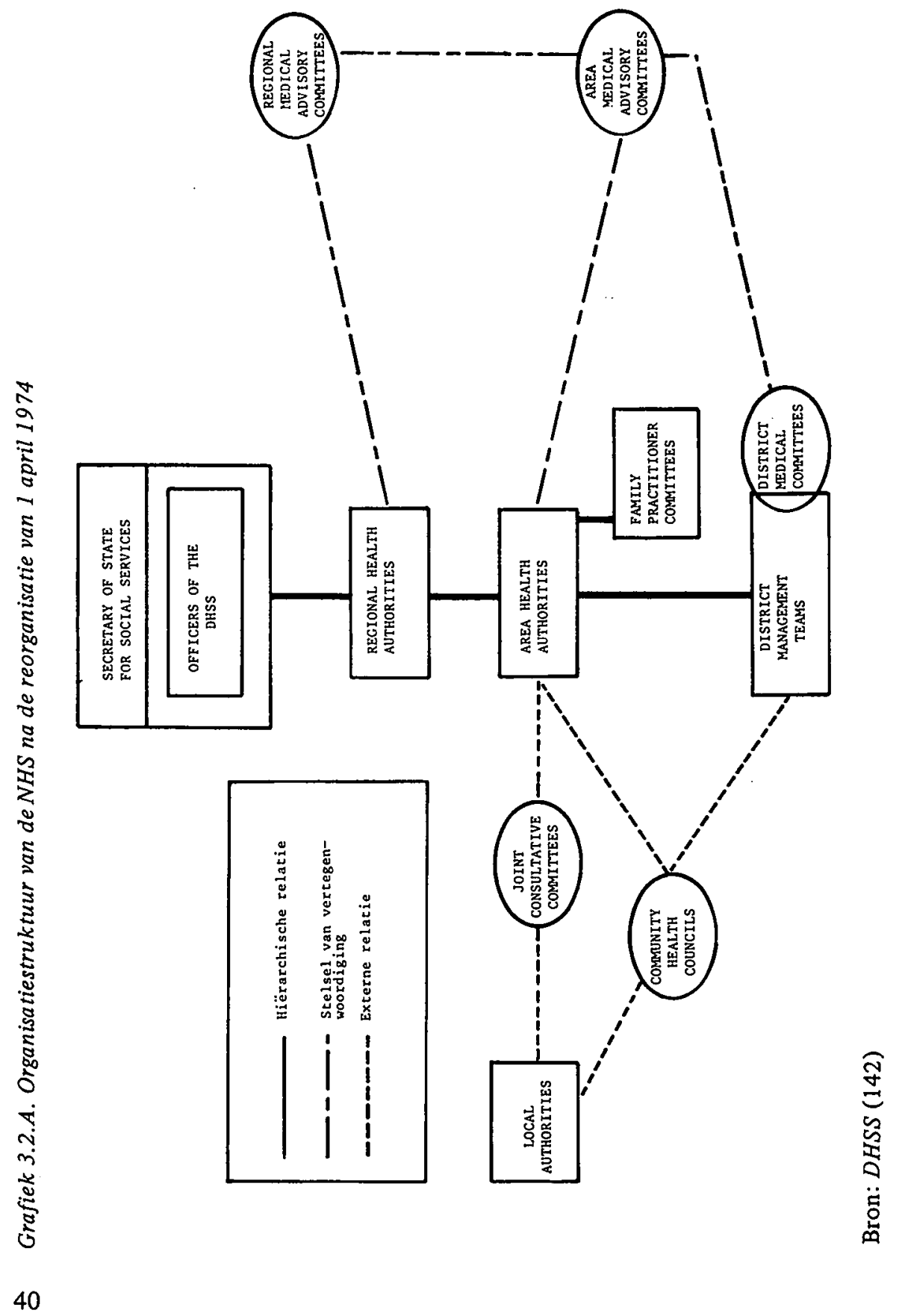


Grafiek 3.2.B. Indeling van de NHS in RHA's

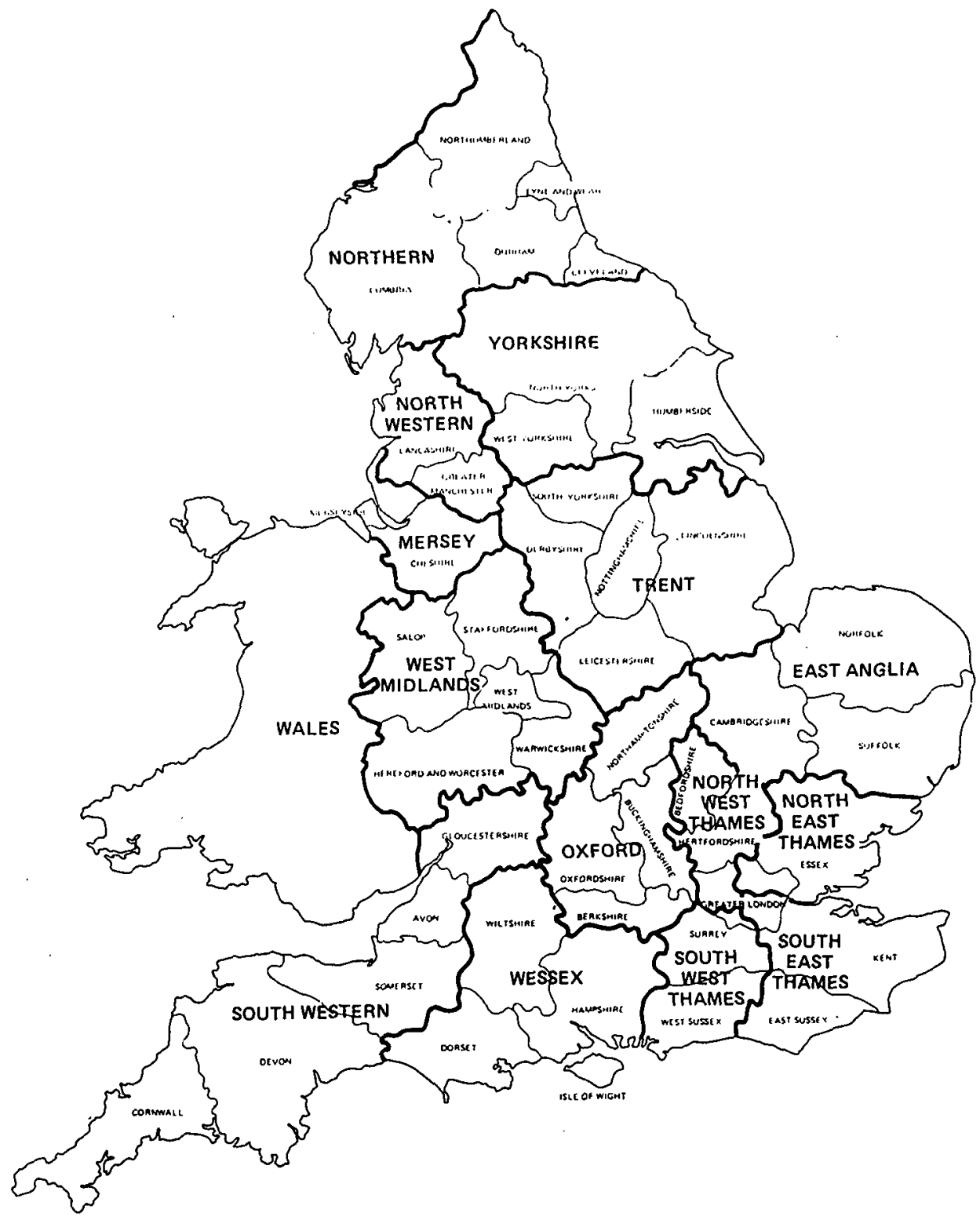

Bron: DHSS (164). 
meer dan een district: dit zijn de multi-district areas. De overige AHA's vallen samen met één district: single district areas. De AHA's vallen geografisch samen met de counties en de boroughs (zie par. 2.1.3.). De RHA's hebben vooral een strategische planningsfunktie, waarbij zij zich baseren op de departementale richtlijnen en op informatie vanuit de "basis". Een RHA bestaat uit vijftien leden, aangesteld door de Minister. De vergelijkbare groep op areaniveau wordt benoemd door de RHA. Binnen de nieuwe organisatie is afstand genomen van het denkbeeld, dat niet betaalde leken-bestuurders belangrijke rollen moeten spelen bij het vaststellen van het beleid en het uitoefenen van managementfunkties binnen de gezondheidszorg. De dagelijkse leiding is op alle niveau's in handen van de professionele officers, steeds voortkomende vanuit vier disciplines: medisch, verpleegkundig, bedrijfskundig en financieel. De "officers" in het DMT staan onder de AHA evenals de areateam-officers. Tussen deze beide groepen officers is evenwel geen gezagsverhouding. De regional officers staan onder de RHA. De multi-professionele teams in de nieuwe struktuur nemen beslissingen volgens het consensusprincipe. Dat wil zeggen, dat er bij besluitvorming overeenstemming bereikt moet worden, anders dan bij stemming het geval is.

Indien een team geen overeenstemming bereikt, wordt de beslissing doorverwezen naar een hogere instantie.

(f Een enigszins uitzonderlijke positie in de geintegreerde struktuur wordt ingenomen door het Family Practitioners Committee (FPC), dat zich bezighoudt met de organisatie der huisartsen, tandartsen, opticiens- en apothekersdiensten. Het funktioneert op area-niveau, doch ressorteert rechtstreeks onder het departement. Het FPC is verantwoordelijk voor de dienstverlening der huisartsen, tandartsen, opticiens en apothekers, die allen onafhankelijk op kontraktbasis werkzaam zijn. De dienstverlening van de FPC's behelst in de praktijk:

a. het afsluiten van kontrakten;

b. sekretariaats- en registratie-werkzaamheden;

c. het funktioneren als klachtenbureau voor patiënten van de Family Practitioners.

De Family Practitioners ontvangen de financiële middelen voor hun aktiviteiten uit een landelijk fonds, dat gevoed wordt door het DHSS.

De inspraak van de medische professie is in de nieuwe struktuur verzekerd door werking van de advisory-machinery, wettelijk vastgelegde adviescolleges op alle niveau's, waardoor de artsen invloed uit kunnen oefenen op de door de uitvoerende organen te nemen beslissingen. Deze advisering was reeds vóór de reorganisatie wettelijk geregeld op basis van de Cogwheel-reports (DHSS, 163). De samenwerking met de lokale overheid is geregeld via een overlegorgaan, de Joint Consultative Committee, waarin vertegenwoordigers van de lokale overheid en de AHA zitting hebben. Verder kent de NHS-struktuur Community Health Councils, raden die maandelijks bijeenkomen ten einde daadwerkelijk gestalte te geven aan het meedenken en meepraten van de patiënt (bevolking) over zaken, betreffende de gezondheidszorg. De Councils bestaan uit circa dertig leden. De helft is afgevaardigd door de plaatselijke overheid. De overigen zijn afkomstig van vrijwilligersorganisaties of leveren op individuele basis hun bijdrage. In de nieuwe struktuur worden de academische ziekenhuizen bestuurd door het DMT van het gebied waarin het ligt. Het distrikt en de AHA worden dan teaching district en teaching area genoemd.

\subsubsection{De organisatiestruktuur van de gezondheidszorg binnen een health-district}

Grafiek 3.2.1.B. bestaat uit een organisatieschema voor een distrikt. Het belangrijkste kenmerk is de funktionele organisatie: funktionarissen met eenzelfde funktie of professie zijn verantwoording verschuldigd aan of worden vertegenwoordigd door 


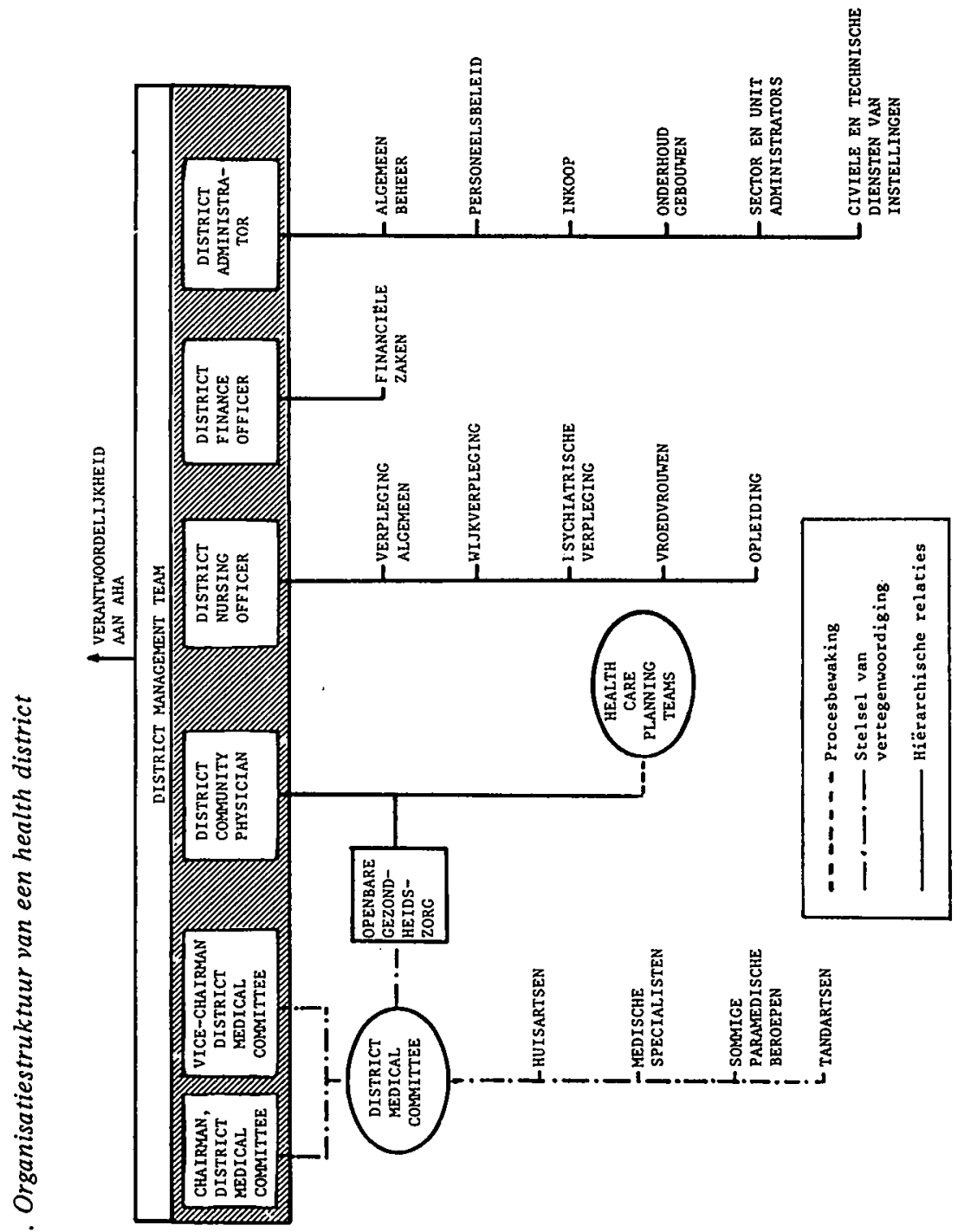

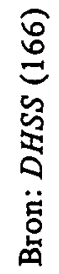


hun professie in het DMT. Het management op instellingsniveau ontbreekt. Binnen het DMT zijn de volgende funkties te herkennen:

1. Chairman district medical committee, part-time lid van het DMT, meestal een medisch specialist, gekozen door vertegenwoordigers van de per specialisme georganiseerde medische staven van de ziekenhuizen in het distrikt.

2. Vice-chairman district medical committee, huisarts, part-time lid van het DMT, gekozen door de huisartsen van het health district.

3. District Community Physician, full-time lid van het DMT, verantwoordelijk voor het funktioneren van de maatschappelijke gezondheidszorg en health care planning teams. Deze laatste teams maken plannen voor de zorgverlening aan bepaalde groepen patiënten, zoals gehandicapten. In zo'n team hebben dan zowel extramurale als intramurale betrokkenen zitting. De leden van zo'n planning team zijn veelal gekozen op persoonlijke titel of op deskundigheid. Als zodanig vormen deze teams de kleinste plangroepen. De plannen van de verschillende teams worden samengevoegd tot een districtplan.

4. District Nurse Officer, full-time lid van het DMT, verantwoordelijk voor het funktioneren van de ziekenhuis- en wijkverpleging en de vroedvrouwenzorg.

5. District Finance Officer, full-time lid van het DMT, verantwoordelijk voor het financieel funktioneren van het district.

6. District Administrator, full-time lid van het DMT, verantwoordelijk voor die taken, die in Nederlandse ziekenhuizen onder de civiele, huishoudelijke en technische diensten vallen, alsmede ook voor de ondersteunende diensten van de nietziekenhuisvoorzieningen.

7. in teaching districts is aan het DMT bovendien een vertegenwoordiger van de medische faculteit toegevoegd.

De funktionele organisatie wordt binnen een distrikt ook op lager niveau dan in het DMT gehanteerd. Gelijksoortige aktiviteiten worden onder de verantwoordelijkheid van één funktionaris gebracht. Zo gaat de District Catering Officer over de keukens van alle ziekenhuizen in het district. De District Superintendant Radiographer gaat over de organisatie van de radiologie zowel in ziekenhuizen als in consultatiebureau's voor bevolkingsonderzoek.

Het verdwijnen van het management op ziekenhuisniveau na de reorganisatie is vooral voor de grotere ziekenhuizen van belang. Tot 1 april 1974 werden de academische ziekenhuizen bestuurd door een eigen Board of Governors, en hadden de grotere, algemene ziekenhuizen veelal een eigen Hospital Management Committee. De kleinere ziekenhuizen - met minder dan 100 bedden - kenden ook vóór de reorganisatie meestal geen eigen managementniveau. $\mathrm{Na}$ de reorganisatie bleef op werkeenheidsniveau wel de funktie bestaan van Sector Administrator en Unit Administrator. Deze funktionarissen coördineren de zorgverlening binnen een beperkte geografische sektor of binnen een grote werkeenheid (unit). $Z_{i j}$ hebben geen hiërarchische relatie met de medewerkers, die zij coördineren.

\subsection{BESLUITVORMINGSSTRUKTUUR VAN DE NHS VANAF 1 APRIL 1974}

In paragraaf 3.1. is aangegeven, dat in 1974 de tripartite structure van de NHS is vervangen door een regionale indeling. Voor de besluitvorming in de NHS heeft dit tot gevolg, dat de beslissingen over de academische ziekenhuizen, de overige intramurale werkeenheden en de maatschappelijke gezondheidszorg niet meer door verschillende instanties naast elkaar worden genomen.

Sinds 1 april 1974 worden deze besluiten genomen door instanties, die in een hiër- 
archische relatie tot elkaar staan, te weten, het DHSS, de RHA, de AHA en het DMT. Deze hiërarchische relatie houdt in, dat een hogere instantie de kaders aangeeft voor de beslissingsruimte van een lagere instantie: het DHSS bepaalt deze ruimte voor de RHA, die dat weer doet voor de AHA. Deze laatste stelt de kaders op voor de besluiten van het DMT. In paragraaf 3.3.1. wordt ingegaan op de kaders ten aanzien van de vorming van de besluiten over aktiviteitenpakket, kapitaalgoederen, arbeidsplaatsen en organisatiestruktuur. In paragraaf 3.3.2. komt het financieringsstelsel aan de orde. De beslissingsbevoegdheden van de general practitioners en de medische specialisten zijn door de reorganisatie niet veranderd. Voor de bespreking van deze bevoegdheden en de relatie ervan met die van gezondheidszorginstanties wordt daarom aangesloten op de tekst in paragraaf 2.3 .

\subsubsection{Planning van de aktiviteiten en de capaciteiten}

In juni 1976, twee jaar na de start van de reorganisatie, publiceerde het DHSS het "NHS planning system" (DHSS, 176). Onder planning verstaat het DHSS: "Deciding how the future pattern of activities should differ from the present, identifying the changes necessary to accomplish this, and specifying how these changes should be brought about" (p. 4). Deze planning bestaat uit:

1. policy analysis and policy making.

2. strategic or long-term planning.

3. operational planning and programming.

4. budgeting.

5. project planning.

Onder strategische planning wordt verstaan: "the means by which NHS-authorities determine their longe-range objectives and priorities for the development of the full range of health services, and plot the course towards achievement of those objectives" (p. 12). Operational planning is: "the process by which decisions are reached on actual changes in pattern of service provision. Rolling 3 years operational plans will be produced each year" (p. 15). Grafiek 3.3.1.1. geeft een schema van de verschillende planningsprocessen. Het District Management Team $(D M T)$ is het laagste planningniveau in de NHS. Het stelt het strategische en het operationele plan op voor het district aan de hand van richtlijnen van het DHSS, de RHA en de AHA. De plannen van verschillende districten binnen een AHA worden samengevoegd tot een AHA-plan, de AHA-plannen tot een plan voor de gehele RHA. De 14 RHA-plannen vormen de basis voor een national strategic, casu quo operational plan. De richtlijnen - de planning guidelines - worden door het DHSS opgesteld op basis van het nationale beleid, de beschikbare middelen en de ingediende plannen. De RHA's en AHA's passen deze richtlijnen aan voor de eigen AHA's respectievelijk districten. Over het aanbod van funkties met een regionale betekenis - bijvoorbeeld topklinische funkties - of met een area betekenis - bijvoorbeeld ambulancevervoer - beslist de RHA en de AHA zelf. Het DMT voert voor deze funkties dan alleen het dagelijkse management. Op basis van de aktiviteiten plannen en de te verwachten financiële middelen stellen de DMT's hun jaarbudget op. Dit jaarbudget is de autorisatie aan de budgethouders tot het doen van uitgaven en het verrichten van aktiviteiten. Bij het opzetten van nieuwe aktiviteiten, het aantrekken van nieuwe medewerkers en de aanschaf van apparatuur heeft de budgethouder echter wel toestemming nodig van de District Treasurer en een (of meer) van de andere DMT-leden. Bij deze toestemming wordt dan in ieder geval nagegaan of een en ander past in het toegewezen budget. In de loop van het jaar worden gegevens over verrichte aktiviteiten en gedane uitgaven teruggekoppeld aan het DMT en aan de budgethouders. Op basis hiervan kunnen dan door het DMT maatregelen worden genomen ten aanzien van 


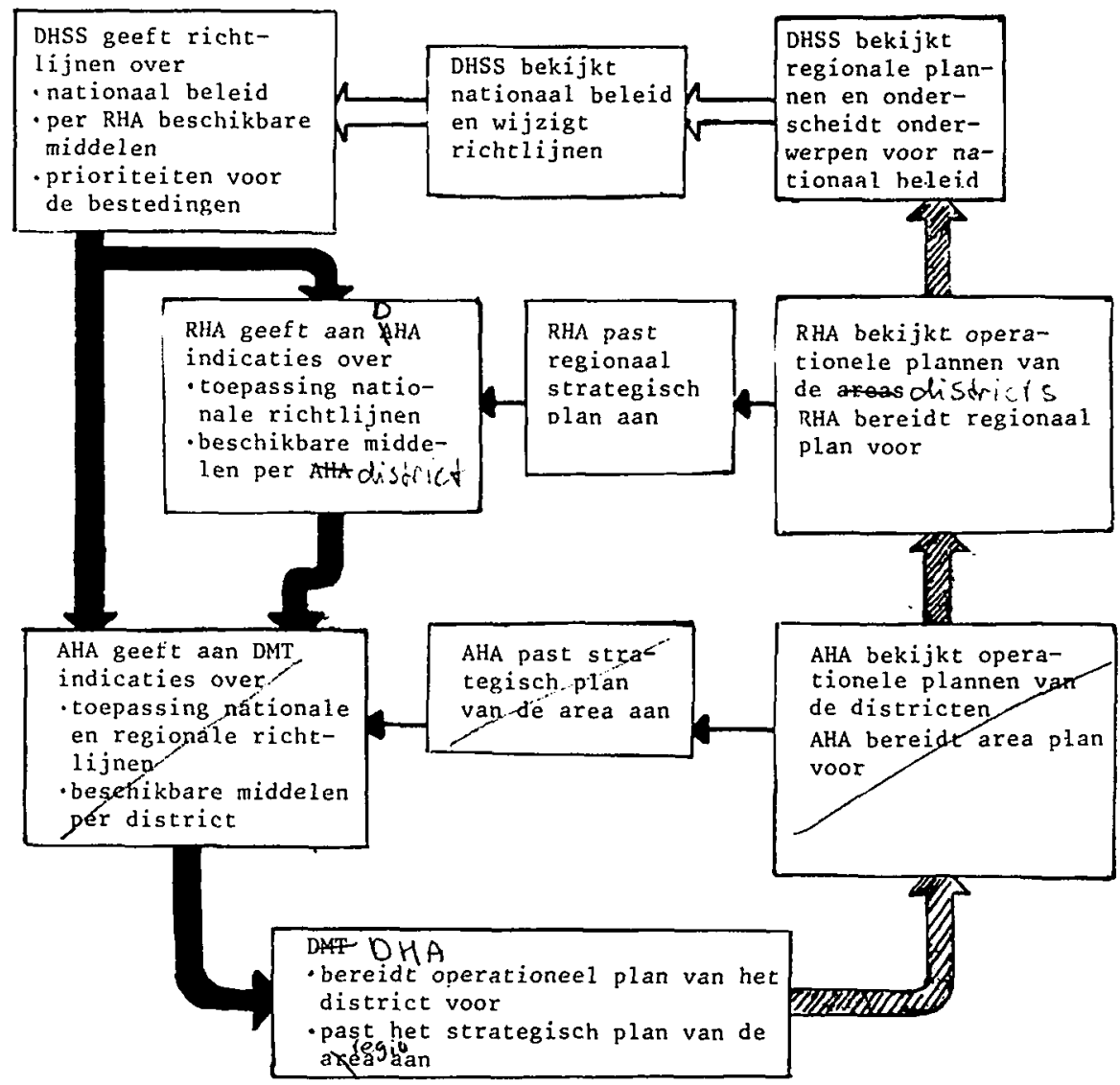

Bron: DHSS (150).

het budget, de aktiviteiten en de uitgaven. Bij het eerste is te denken aan verschuiving van begrotingsposten, waardoor overschotten en tekorten van verschillende budgethouders kunnen worden gecompenseerd. Ook is te denken aan het doorberekenen van door het DHSS tussentijdse aangebrachte veranderingen van budgetten. Bij maatregelen ten aanzien van de aktiviteitenontwikkeling is te denken aan gesprekken met de verschillende medische adviescolleges. De rechtstreekse bevoegdheid over de aktiviteiten is aan de individuele medicus en niet aan het DMT. Indirekt is er, zoals ook voor de reorganisatie het geval was, wel een invloed hierop van het DMT via haar beslissingen over de infrastruktuur. Grafiek 3.3.1.2. geeft als voorbeeld hiervoor de wegen aan, die een arts moet bewandelen om apparatuur - medical and scientific equipment - te verwerven. De apparatuuraanvragen worden onderverdeeld in Major Capital, Minor Capital en Revenue (zie grafiek 3.3.1.2.). Over 
Grafiek 3.3.1.2. Schema van het verwerven van medische apparatuur, gezien vanuit de individuele medisch specialist

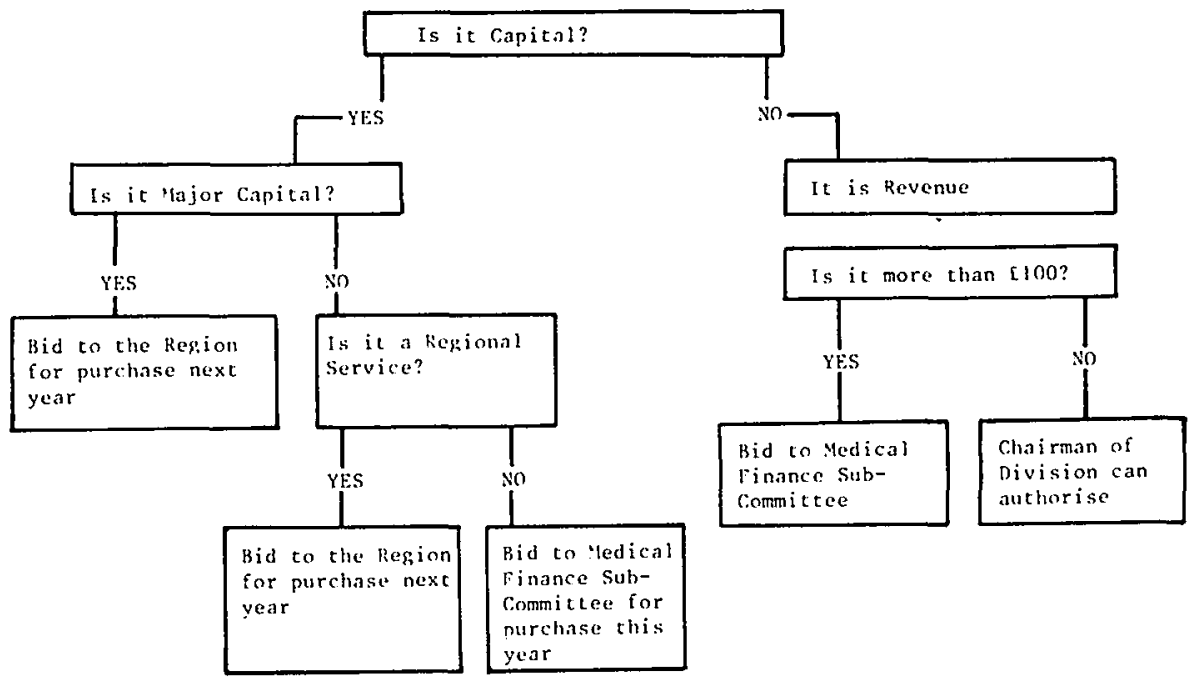

Bron: Southampton S.W. Hampts Health District.

Definities

Major Capital - Uitbreiding van apparatuur, duurder dan $£ 10.000$

- Vervanging van apparatuur, duurder dan $£ 35.000$

Minor Capital - Uitbreiding van apparatuur van $£ 5000-£ 10.000$

- Vervanging van apparatuur van $£ 5000-£ 35.000$

Revenue - Apparatuur beneden $£ 5000$

Medical Finance Sub-Committee - Commissie van de Medical Executive Committee, die bestaat uit vertegenwoordigers van per specialisme, georganiseerde medisch specialisten in het district.

Chairman of Division - Voorzitter van de vergadering van gezamenlijke specialisten van een specialisme (= division).

Major Capital beslist de Region (de RHA), over Minor Capital de Medical Finance Sub-Committee, en over Revenue de Chairman of the Division.

Indien in de loop van het jaar de uitgaven ten gevolge van aktiviteitengroei de begroting (dreigen te) overschrijden, is het DMT in staat de uitgaven in de rest van het jaar te verminderen door een tijdelijk niet-vervullen van vakatures of de apparatuuraanschaf uit te smeren over een langere periode dan begroot. Uitgaven aan middelen, waarover rechtstreeks door een medicus wordt beslist, zoals het voorschrijven van medicijnen, het gebruik van röntgenfoto's en laboratoriumonderzoeken, worden niet op deze wijze ingeperkt. Overschrijding hierop wordt gecompenseerd ofwel hetgeen meestal gebeurt - tegen overschotten op andere begrotingsposten ofwel door algemene besnoeiingen op aantallen arbeidskrachten, apparatuuromvang en andere middelen (zie ook: Royal Commission on the NHS, 230, p. 108).

Verschillende besluiten ten aanzien van kapitaalgoederen, arbeidsplaatsen en de organisatiestruktuur binnen de RHA worden in laatste instantie op nationaal niveau 
genomen. Deze besluiten worden voorbereid en uitgevoerd op de lagere managementsniveau's. Over kapitaalgoederen heeft de RHA - ook indien financiële middelen reeds beschikbaar zijn - toestemming nodig van het DHSS op de volgende punten (de genoemde bedragen hebben betrekking op het financiële jaar 1976-1977):

- nieuwbouw boven $£ 350.000$

- aankoop van grond boven $£ 100.000$

- huur van een pand met een huur boven $£ 15.000$ per jaar.

Ten aanzien van de arbeidsplaatsen is apart toestemming op nationaal niveau nodig voor de uitbreiding van het aantal arbeidsplaatsen voor medisch specialisten. De procedure hierbij is als volgt: de AHA ontvangt de aanvragen voor een nieuwe arbeidsplaats van de districts. Het zet deze aanvragen op een lijst in volgorde van prioriteit en stuurt deze lijst naar het Regional Manpower Committee (RMC), waarin hoofdzakelijk medici zitting hebben. Deze RMC stelt een prioriteitenlijst op van de aanvragen van de verschillende AHA's en stuurt op haar beurt deze door naar de Central Manpower Committee (CMC), die voor het merendeel uit artsen bestaat maar waarin ook het DHSS is vertegenwoordigd. Het CMC wijst de arbeidsplaatsen toe aan de RHA's, die dat op hun beurt doen aan de AHA's. Deze laatsten kennen de arbeidsplaatsen toe aan de districts (zie Royal Commission on the NHS, 230, p. 49). Voor de vervulling van de meeste topfunkties, senior posts, van de NHS-authorities en voor het vaststellen van de arbeidsvoorwaarden is eveneens toestemming nodig van het DHSS. Over de organisatiestruktuur heeft het DHSS beslissingsbevoegdheid ten aanzien van:

- het veranderen van de geografische grenzen van districts, AHA's en RHA's

- het sluiten - of het veranderen van de funktie - van werkeenheden. Indien zowel de AHA als de CHC een werkeenheid willen sluiten, wordt deze toestemming zonder meer verleend.

Voor een uitvoerige beschrijving van de voorbereiding, vorming en uitvoering van bovenstaande besluiten zij verwezen naar een rapport van de voorzitters van de veertien Engelse RHA's (DHSS, 177), en de Research Paper nr 2 van de Royal Commission on the NHS (230).

\subsubsection{Het financieringsstelsel}

3.3.2.1. Regionale financiering: periode 1974-1975 tot en met 1976-1977

In paragraaf 2.3. is aangegeven hoe de NHS in een periode $1948-1974$ werd gefinancierd. Vermeld werd dat in het financiële jaar 1971-1972 bij de RHB's voor het eerst gewerkt werd met een financiering op basis van een formule. In de financiële jaren 1974-1975 en 1975-1976 blijft de financiering in grote lijnen gelijk aan die van vóór de reorganisatie. Alleen de community health services worden niet meer door de lokale maar door de rijksoverheid gefinancierd. Voor het financiële jaar 1976-1977 wordt een toewijzingsformule toegepast voor de gehele gezondheidszorg in een bepaalde regio in plaats van alleen de ziekenhuizen. Om deze formule te ontwerpen wordt in mei 1975 door de regering de Resource Allocation Working Party, hierna te noemen RAWP, ingesteld met de volgende opdracht:

"To review the arrangements for distributing NHS capital and revenue to RHA's, AHA's and Districts respectively with a view to establishing a method of securing, as soon as practicable a pattern of distribution responsive objectively, equitably, and efficiently to relative need and to make recommendations" (DHSS, 173).

De RAWP moet alleen voor Engeland voorstellen doen. Ze is samengesteld uit twaalf personen afkomstig van de verschillende NHS instanties en uit twaalf personen van het DHSS. In augustus 1975 komt de RAWP met een interimrapport op basis waarvan een verdeling van de gelden in het financièle jaar 1976-1977 wordt voorgesteld 
(DHSS-162). Tussen de voorstellen uit dit rapport en het toewijzingsbeleid van vorige jaren is één groot verschil: wat betreft het aantal bedden als toewijzingscriterium is verdwenen. Over blijft voor de zorg uit ziekenhuizen: de bevolking gewogen naar leeftijd en geslacht en de case-load factor, het aantal klinisch behandelde patiënten. Het landelijk budget voor ziekenhuiszorg wordt dan verdeeld over de regio's zowel naar gewogen bevolkingsomvang als naar aantal behandelde patiënten. De resultaten van beide toewijzingen worden dan gemiddeld in een verhouding van $3: 1$. De budgetten voor community services worden toegewezen op basis van de bevolking, gewogen naar leeftijd en geslacht. De Family Practitioners Committees ontvangen hun financiële middelen van de AHA. Hierbij is sprake van een open budget, dat de ontwikkeling van de aktiviteiten volgt. Dit houdt in, dat de kosten van huisartsenhulp, medicijnengebruik, tandartsenhulp en opticiensdiensten automatisch zonder limiet (via de FPC) door de AHA worden vergoed en door deze ook kunnen worden verhaald op het DHSS. Deze uitgaven vallen zelfs buiten de cash-limits van de rijksoverheid (zie par. 2.1.). De beheerskosten van de Family Practitioners Committees vallen wel onder de toewijzing van de RAWP-voorstellen. Deze worden gelijk behandeld als de kosten van de community services.

De RAWP adviseert voor de toewijzing in 1976-1977 dat geen enkele RHA meer dan $2,5 \%$ ten opzichte van 1975-1976 mag groeien of dalen (DHSS, 162). Een RHA is volgens haar namelijk niet in staat zijn bestedingen met meer dan $2,5 \%$ in een jaar tijd te beperken. Evenmin is een RHA in staat, volgens de RAWP, een groei in de toegewezen budgetten van meer dan 2,5\% per jaar te absorberen. Deze 2,5\%-grens is exclusief de toewijzing van budgetten ten behoeve van RCCS's (Revenue Consequences of Capital Schemes) uit het verleden.

Ook de RCCS's van investeringen in 1976-1977 vallen buiten de 2,5\%-grens. Op 18 februari 1976 maakt de Secretary of State in een brief aan de RHA-voorzitters (DHSS, 223) de toewijzing van de budgetten voor 1976-1977 bekend.

De voorstellen van de RAWP worden overgenomen met de volgende verschillen:

- geen enkele regio krijgt een lager toegewezen budget dan in 1975-1976. De benedengrens is dus niet $2,5 \%$ maar $0 \%$.

- geen enkele regio krijgt een budget toegewezen, dat hoger is dan $4 \%$ in plaats van $2,5 \%$ van het budget in 1975-1976. De Secretary of State wijkt af van dit deel van het RAWP-voorstel, omdat ze tegelijk een grotere ruimte toestaat om een deel van het exploitatiebudget (t.w. $1 \%$ in plaats van $0,25 \%$ ) aan te wenden als investeringsbudget. Vanwege een gebrek aan financiële middelen op landelijk niveau kunnen niet alle negen minderbedeelde regio's met $4 \%$ groeien. De minstbedeelde regio's - Wessex, Trent en East Anglia - mogen daarom met 4\% groeien, de andere worden op een gelijk niveau gebracht van 96,75\% van het budget waarop ze volgens de RAWP-formule uit moeten komen.

\subsubsection{RAWP-yoorstellen voor de periode vanaf 1977-1978}

In september 1976 komt de RAWP met een eindrapport (DHSS, 173), dat nogal afwijkt van het tussenverslag in 1975. Omdat in dit eindrapport, getiteld "Sharing resources for health in England" de regionale financiering van gezondheidszorg grondig aan de orde komt, wordt het hieronder uitvoerig besproken. Het 134 pagina's tellende eindrapport van de RAWP is opgebouwd uit zes hoofdstukken en een aantal bijlagen. In de zes hoofdstukken wordt achtereenvolgens besproken:

- het vraagstuk in zijn algemeenheid (1) en de verschillende criteria (2)

- de verdeling van de exploitatiekosten naar AHA's en Distrikten (3)

- de verdeling van de kosten van het medische en tandheelkundige onderwijs (4)

- de verdeling van kapitaal (5) 
- de invoering van de nieuwe verdelingsmethode (6)

In de opdracht aan de RAWP worden de relative needs, te vertalen als relatieve zorgbehoeften, als richtsnoer aangegeven voor het verdelen van de budgetten over de bevolking. Het totale budget voor de NHS wordt in principe over de RHA's verdeeld naar rata van het inwonertal. Het werkelijke inwonertal wordt hierbij statistisch gewogen met gewichten, die de zwaarte van de invloed van de verschillende zorgbehoeften aangeven. Op basis van health needs komt de RAWP tot drie budgetten: het exploitatiebudget voor de zorgverlening, het investeringsbudget voor de zorgverlening en het onderwijsbudget, een exploitatiebudget voor het ter beschikking stellen van faciliteiten voor de opleiding van medische en tandheelkundige studenten.

\subsection{Financiering exploitatie}

Grafiek 3.3.2.2.1. geeft een schematisch overzicht van het vaststellen van een exploitatiebudget voor een regio. Eerst wordt de te verdelen zorg verdeeld in zeven soorten, namelijk:

1. non psychiatric in-patient services;

2. all day-and out-patients services;

3. mental illnes in-patient services;

4. mental handicap in-patient services;

5. community services (exclusief het ambulance-vervoer en de FPC-diensten);

6. het ambulance-vervoer;

7. de beheerskosten voor de FPC's,

Daarna wordt de regiobevolking gewogen met de gemiddelde nationale consumptie per leeftijd en geslacht.

De nationale gemiddelde consumptie voor de non psychiatric in-patient services wordt gemeten met behulp van het aantal verpleegdagen per 1000 inwoners. De bevolking wordt dan verdeeld in 18 groepen ( 9 leeftijdsklassen $\times 2$ geslachtsklassen). Vermenigvuldiging van de bevolkingsomvang van zo'n groep met het bijbehorend landelijk gemiddelde aantal verpleegdagen per 1000 inwoners levert dan een landelijk aantal verpleegdagen op: de som voor alle achttien groepen wordt dan uitgedrukt als percentage van het totale aantal verpleegdagen in Engeland. De statistisch gewogen bevolking voor non psychiatric in-patient services is dan dit percentage maal de nationale Engelse bevolking. Op dergelijke wijze wordt de bevolking gewogen voor de andere soorten zorg.

De nationale consumptie wordt gemeten in achtereenvolgens:

2. all day- and out-patient services: aantallen polikliniekbezoeken per 1000 inwoners per leeftijds- en geslachtskategorie.

3. mental illnes in-patient services: aantallen verpleegdagen in psychiatrische ziekenhuizen per 1000 inwoners per leeftijds- en geslachtskategorie en al dan niet gehuwd zijn.

4. mental handicap in-patient services: aantallen verpleegdagen in inrichtingen voor geestelijk gehandicapten per 1000 inwoners per leeftijds- en geslachtskategorie.

5. community services (exclusief ambulance-vervoer en FPC-diensten): alleen de werkelijke bevolking.

6. het ambulance-vervoer: alleen werkelijke bevolking.

7. FPC-beheerskosten: deze kosten betreffen de huisvesting en arbeidskosten vạn administratieve medewerkers van de Family Practitioners Committees. De uitkeringen worden berekend op basis van de werkelijke kosten.

Naast de opbouw van de bevolking naar leeftijd en geslacht zijn er volgens de RAWP vele andere factoren van invloed op de zorgbehoefte. Te noemen zijn de sociale opbouw van de bevolking, de struktuur van de werkgelegenheid en milieufactoren. Het 


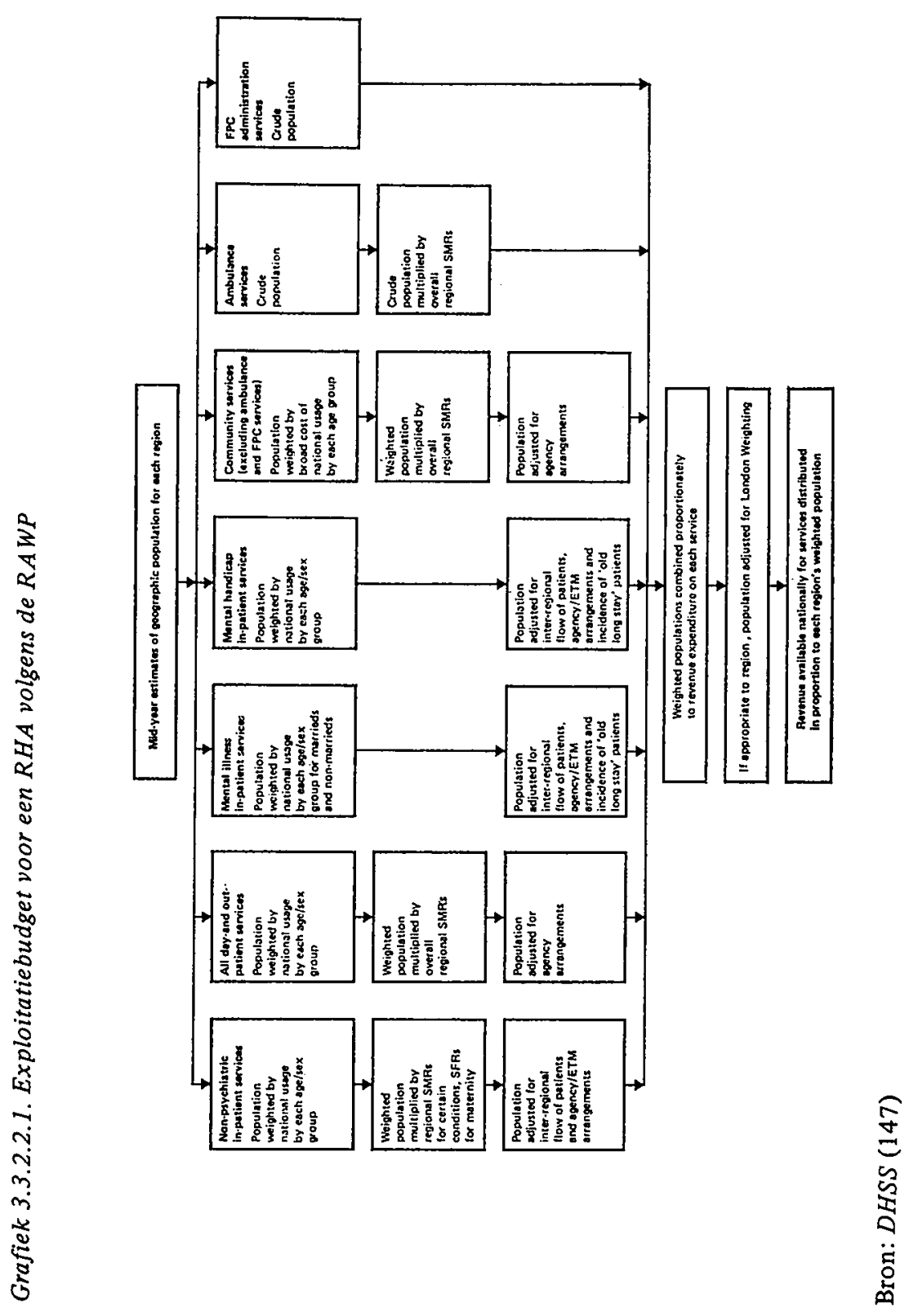


probleem is, aldus de RAWP, dat de invloed van deze factoren afzonderlijk op de morbiditeit moeilijk te analyseren en te kwantificeren is. Met deze factoren hoeft geen rekening te worden gehouden, indien de morbiditeit rechtstreeks gemeten zou kunnen worden. Hierbij is ten eerste te denken aan het meten van een aantal patiënten, aan wie zorg is geleverd. Op deze wijze werd in de formule voor het toewijzen van gelden naar RHB van 1971-1972 tot de reorganisatie rekening gehouden met het aantal behandelde patiënten. Een bezwaar hiervan is, dat de morbiditeit van niet-behandelde patiënten niet wordt gemeten. De op deze wijze rechtstreeks gemeten morbiditeit wordt hierdoor sterk bepaald door het aanbod van zorg (DHSS, 173, p. 15). Minder afhankelijk van het zorgaanbod, zo stelt de RAWP, is de morbiditeit gemeten met het aantal ziekmeldingen in bedrijven of met het percentage respondenten, dat in daartoe te houden enquêtes zichzelf als zorgbehoevend of ziek beschouwt. Het bezwaar van het op deze wijze meten van de zorgbehoefte is het missen van de mensen, die wel zorg behoeven, maar gewoon doorwerken of zichzelf als gezond beschouwen. Bovendien is de relatie tussen ziekmelding - in het bedrijf of in de enquête - en de omvang van de zorgbehoefte moeilijk te leggen. Om toch de morbiditeit rechtstreeks te kunnen meten introduceert de RAWP sterfteciffers met de volgende overwegingen: (DHSS, 173, p. 15): de kwaliteit van de statistieken is hoog, ook indien uitgesplitst naar doodsoorzaak, regio en diagnosegroepen.

De regionale verschillen zijn groot. De hoogste en laagste waarden van de gestandaardiseerde sterftecijfers verschillen voor mannen $28 \%$ en voor vrouwen $21 \%$ van elkaar. Deze verschillen worden verklaard, zo gelooft de RAWP, door de verschillen in morbiditeit. Dit geloof is gebaseerd op de relatie tussen de ziekmeldingen en algemene enquêtes naar het zichzelf ziek achten en de mortaliteit (DHSS, 173, p. 16). De invloed van de mortaliteit wordt gewogen met de standaardsterftecijfers (SMR's). Het principe voor de acute, non psychiatric in-patient care is dat een regio met een standaardsterftecijfer (SMR) van bijvoorbeeld 105 zijn bevolking met $5 \%$ mag vergroten. $O m$ dit laatste percentage nauwkeuriger te berekenen verdeelt de RAWP deze sterftecijfers evenwel eerst in naar zeventien diagnosegroepen, overeenkomstig de International Classification of Diseases.

In een algebraïsche formule luidt de gehele weging naar leeftijd, geslacht en sterftecijfer dan:

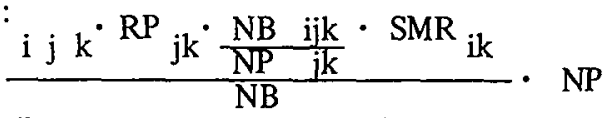

Waarin: $\mathrm{NP}=$ Nationale bevolking (National Population)

$\mathrm{NB}=$ gemiddeld aantal verpleegdagen per dag in Engeland

$R P=$ regio bevolking (Regional Population)

$\mathrm{i}=$ diagnosegroep

$\begin{array}{ll}\mathrm{j} & =\text { leeftijdsgroep } \\ \mathrm{k} & =\text { geslacht }\end{array}$

En als rekenvoorschrift luidt de berekening:

a. bepaal van een diagnosegroep het gemiddeld aantal verpleegdagen per dag in Engeland per 1000 inwoners voor een willekeurige leeftijdsgroep en geslachtsgroep $\left(\frac{N B}{\mathrm{NP}}-\mathrm{jk} k\right)$.

b. vermenigvuldig dit getal $\frac{\mathrm{NB} i \mathrm{jk}}{\mathrm{NP} j \mathrm{jk}}$ met het aantal inwoners in de regio in de betrokken leeftijds- en geslachtskategorie ( $R P{ }_{j k}$ ). Dit levert een aantal verpleeg-
dagen op.

c. vermenigvuldig dit aantal met het SMR van de regio voor de betrokken diagnose-en geslachtsgroep. 
d. herhaal a $t / m$ c voor alle diagnosegroepen en voor alle leeftijds- en geslachtsgroepen en tel de uitkomsten sub c op.

De som is het naar leeftijd, geslacht en sterftecijfer gecorrigeerd aantal verpleegdagen van de regio.

e. deel de som sub d door het aantal verpleegdagen per dag in Engeland. De uitkomst is een percentage.

f. vermenigvuldig de landelijke bevolking met dit percentage. De uitkomst is de naar leeftijd, geslacht en morbiditeit gecorrigeerde bevolking van de regio.

De diagnosegroepen huidziekten en kraamzorg worden niet vermenigvuldigd met SMR's. Bij huidziekten wordt dat niet gedaan vanwege de zeer lage mortaliteit. Bij kraamzorg wordt in plaats van de SMR's de gestandaardiseerde vruchtbaarheidscijfers gebruikt.

De naar leeftijd en geslacht gewogen bevolking voor all day- and out-patient services, de community services en het ambulance-vervoer worden op soortgelijke wijze vermenigvuldigd met de SMR van een regio. Een uitsplitsing naar diagnosegroep vindt evenwel niet plaats. In het RAWP-report wordt het werkelijke inwonertal vergeleken met dat gewogen naar leeftijd, geslacht en mortaliteit. Het tweede als percentage van het werkelijke inwonertal schommelt tussen $86 \%$ voor de Oxford region en $110 \%$ voor de North Western region (DHSS, 173, p. 18-19). De financiering van een regio moet, zoals gesteld, in overeenstemming zijn met de zorgbehoefte van de inwoners van die regio.

Er zijn evenwel altijd inwoners uit regio A die zorg ontvangen in regio B. Dit zijn de cross boundary flows of patients ofwel het grensoverschrijdend patiëntenverkeer. De financiering van een regio dient met deze patiënten rekening te houden, in die zin, dat de hierbovengenoemde regio A wordt geçrediteerd en regio B wordt gedebiteerd voor de gemaakte kosten.

In Engeland gebeurt deze onderlinge verrekening voor opgenomen ziekenhuispatiënten als volgt (DHSS, 173, p. 106):

a. de cross boundary flows van elke regio en elk specialisme staan vermeld in de Hospital Activity Analysis gegevens.

b. deze gegevens worden per regio geaggregeerd voor een aantal groepen van specialismen met vergelijkbare kosten per opname.

c. de netto patiëntenstromen van deze groepen van specialismen worden berekend en vermenigvuldigd met de gemiddelde kosten per opname in Engeland voor die groep.

d. het resultaat sub $\mathrm{c}$ wordt omgezet in bevolkingsequivalenten door vermenigvuldiging met de gemiddelde kosten in Engeland voor die groep specialismen per hoofd van de bevolking. Dit equivalent wordt dan opgeteld bij de bevolking,gewogen naar leeftijd, geslacht en mortaliteit.

Voor andere soorten zorg dan de klinische zorg wordt bij gebrek aan informatie minder gedetailleerd rekening gehouden met de pendelende patiënten. Bij de dayen out-patient services wordt alleen gekeken naar de overeenkomsten - agency arrangements - tussen regio's. Het komt namelijk voor dat een bepaalde voorziening onder beheer van regio $\mathrm{A}$ zich bevindt in regio $\mathrm{B}$.

Met de buiten de eigen regio verleende zorg aan psychiatrische patiënten en geestelijk gehandicapten wordt als volgt rekening gehouden. De centrale veronderstelling is dat het behandelen van elke psychiatrische patiënt voor elke regio evenveel kost. De netto patiëntenstroom is dan om te zetten in bevolkingsequivalenten door vermenigvuldiging met het gemiddeld aantal patiënten in Engeland per hoofd van de bevolking. Met patiënten die reeds langdurig, althans vóór 1970 zijn opgenomen in een instelling voor psychiatrische of geestelijk gehandicapten buiten de eigen regio, 
wordt rekening gehouden door hun werkelijke aantallen in een regio af te trekken van de te verwachten aantallen op basis van de naar leeftijd en geslacht gewogen bevolking. De uitkomst van deze aftreksom wordt dan opgeteld bij de netto patiëntenstroom na 1970, waarna omzetten in bevolkingsequivalenten plaatsvindt. Door optelling van al deze equivalenten bij de reeds naar leeftijd, geslacht en mortaliteit gewogen bevolking is ook de weging voor de pendelende patiëntenstromen een feit.

Tot nu toe zijn de relatieve behoeften aan de zeven verschillende soorten zorg gemeten door de regionale bevolking te wegen voor leeftijdsopbouw, geslachtsverdeling, mortaliteit en pendelende patiënten. Om vanuit deze zeven bevolkingen van een regio te komen tot één regio-exploitatiebudget wordt de bevolking van elke zorgsoort vermenigvuldigd met het aandeel van deze zorgsoort in het totaal van de uitgaven aan gezondheidszorg in Engeland. Gebruikt wordt hierbij de meest recente informatie: voor het jaar 1977-1978 de uitgaven van het jaar 1975-1976. Voordat de begroting voor de NHS in Engeland naar rata van de gewogen bevolking over de regio's wordt verdeeld, wordt de bevolking eerst nog gewogen voor het hogere prijspeil in Londen. Om dezelfde redenen als voor 1976-1977 beveelt de RAWP in haar eindrapport ook beneden- en bovengrenzen aan voor de toewijzingen in 1977-1978. De RAWP geeft als bezwaar tegen het stellen van alleen grenzen, dat een bepaalde regio eerst gedurende een aantal jaren mag groeien, maar daarna op een stationair niveau moet blijven. Deze overgang van grote groei naar geen of geringe groei kan op zich tot aanpassingsmoeilijkheden leiden (DHSS, 173, p. 29). Daarom adviseert de RAWP, dat de groei- of daalsnelheid van een regio wordt bepaald door de afstand tussen budgettoewijzing op basis van de formule en de toewijzing in het verleden. De RAWP adviseert dan tot een maximale groei, hoe dan ook, van 5\% inclusief de RCCS's. Indien het landelijk budget voor gezondheidszorg met meer dan $1 \%$ stijgt, adviseert de RAWP een daling van $1 \%$ als benedengrens voor de overbedeelde regio's. Bij een geringere landelijke groei, stelt de RAWP de benedengrens lager, maximaal $2,5 \%$. De voorstellen die de RAWP doet voor 1977-1978 op basis van de nieuwe formule, zijn voor sommige RHA's nogal verschillend van die voor 1976-1977. Het in dit laatste financiële jaar overbedeelde Mersey wordt in 1977-1978 onderbedeeld geacht. Oxford blijkt in de voorstellen voor 1977-1978 een rijke RHA te zijn in tegenstelling tot die voor 1976-1977. De introduktie van de SMR's hebben vooral geleid tot deze verschillen. Deze worden echter weer gedeeltelijk gecompenseerd door het verdwijnen van de case-load-factor in 1977-1978 ( $D H S S, 173$ p. 76 en verder).

De RAWP geeft geen aparte adviezen voor het berekenen van exploitatiebudgetten voor de area's en districten. Ze moeten op dezelfde wijze worden bepaald als de RHA-budgetten. Het RHA-budget is dan uitgangspunt voor het bepalen van het districtsbudget. Een belangrijk punt is dat eerst het districtsbudget wordt bepaald en daarna door optelling van deze het AHA-budget. De RAWP geeft in zijn rapport nadrukkelijk aan, dat bij toepassing van de regio-formule voor distrikten rekening moet worden gehouden met de plaatselijke omstandigheden. De regio mag dus van de formule afwijken ( $D H S S, 173$, p. 37 en verder).

\subsection{Financiering van faciliteiten van onderwijs aan medische en tandheelkun- dige studenten}

De NHS is wettelijk verplicht klinische faciliteiten ter beschikking te stellen voor het opleiden van medische en tandheelkundige studenten. De ziekenhuizen, waar deze voorzieningen worden aangetroffen, noemt de RAWP per definitie academische ziekenhuizen (teaching hospitals). De budgetten hiervoor noemt de RAWP Service Increment for Teaching, afgekort SIFT. De SIFT's worden uitgekeerd uit een apart 
landelijk DHSS-budget. De hoogte van de SIFT wordt als volgt bepaald (DHSS, 173, p. 46 e.v.):

de kosten van elk Engels academisch ziekenhuis worden vergeleken met het gemiddelde van een steekproef van 45 vergelijkbare niet-academische ziekenhuizen. De extra kosten - het verschil met dit gemiddelde - wordt dan voor elk academisch ziekenhuis uitgerekend per opgeleide student. De mediaan ( $£ 9500$ in prijzen van maart 1975) van deze extra kosten is dan het uitgangspunt voor de SIFT. Omdat academische ziekenhuizen evenwel niet alleen hogere kosten hebben door hun onderwijs, maar ook centres of excellence zijn, wordt voor de SIFT slechts $75 \%$ van deze extra kosten meegenomen. De veronderstelling is namelijk - op basis van econometrisch onderzoek - dat slechts $75 \%$ van deze extra kosten door het onderwijs wordt veroorzaakt en $25 \%$ door het verlenen van geavanceerde zorg. De kosten van het verlenen van deze topzorg worden geacht te worden betaald uit de gewone exploitatiebudgetten. De SIFT voor de Londense RHA's in verband met hogere prijzen aldaar wordt statistisch gewogen met de factor London Weighing. Ook vindt er voor deze RHA's nog een correctie plaats voor de kleinere geldstromen vanuit het Ministerie van Onderwijs naar de medische faculteiten aldaar.

Vrijwel alle academische ziekenhuizen, die tekort komen op basis van deze formule staan in Londen. Over de wijze waarop het aantal studenten per academisch ziekenhuis moet worden bepaald, geeft de RAWP nog verdere aanwijzingen. In het kader van deze studie wordt deze niet besproken.

Voor twee nationale researchziekenhuizen, de Northwick Park en Hammersmith Hospitals, beide in Londen zonder medische studenten, maar wel met specialistenopleidingen, wordt een aparte regeling getroffen voor hun onderwijskosten. De RHA's worden geacht op een analoge wijze de SIFT door te rekenen naar de districts.

\subsection{Financiering van investeringen}

Het beschikbare investeringsbudget voor de gezondheidszorg zou volgens de RAWP als volgt over de regio's moeten worden verdeeld (DHSS, 173 , p. 62 en verder). Eerst wordt de in een RHA aanwezige kapitaalgoederenvoorraad tegen vervangingswaarde gewaardeerd. Dan wordt de bevolking statistisch gewogen op dezelfde wijze als voor de exploitatiebudgetten. Een uitzondering is, dat met de regiogrens overschrijdende patiëntenstroom geen rekening wordt gehouden. De filosofie is, dat iedere RHA alleen voor zijn eigen inwoners een alles omvattende zorg moet kunnen aanbieden. Het toewijzen van investeringsruimte wordt hierbij gezien als een instrument om deze patiëntenstromen te verminderen. Een norm voor de kapitaalgoederenvoorraad wordt vastgesteld op basis van het aanwezige en toe te wijzen kapitaal. Elke RHA krijgt evenwel een minimum aandeel in het nieuw te investeren kapitaal. Het verdelen van de jaarlijkse kapitaalsbudgetten moet, zodra de kapitaalgoederenvoorraad voor elke RHA even groot is, alleen op basis van de statistisch gewogen bevolking plaats vinden. Het toewijzen van investeringsbudgetten van de RHA's naar de districten gebeurt op een analoge manier. Ook deze districten moeten mettertijd voor hun inwoners een volledige zorg kunnen aanbieden. Voor nieuwe steden mag bij het toewijzen van RHA naar districten een aparte regeling worden gemaakt. Bij het toewijzen naar de RHA's gebeurt dit niet. Het investeren in voorzieningen voor medisch onderwijs valt niet onder de hier aangegeven regeling, het investeren in gezondheidscentra wel.

\subsection{Samenvatting $R A W P$-voorstellen}

De vorige paragrafen samenvattend is te concluderen dat een RHA drie budgetten toegewezen krijgt. Het exploitatiebudget wordt toegewezen op basis van de bevol- 
kingsomvang gewogen naar leeftijd, geslacht, mortaliteit, grensoverschrijdend patiëntenverkeer en prijsverschillen. Het onderwijsbudget wordt toegewezen naar het aantal studenten en een uitkering per student (SIFT). Het investeringsbudget wordt toegewezen op basis van de bevolkingsomvang, gewogen naar leeftijd, geslacht, mortaliteit en aanwezige kapitaalgoederenvoorraad.

\subsection{DOELSTELLINGEN GEZONDHEIDSZORG}

\subsubsection{Niveau en kwaliteit handhaven}

Over de defacto ontwikkeling van de aktiviteitenontwikkeling van de NHS na de reorganisatie, waren bij de afsluiting van dit onderzoek (voorjaar 1979) gegevens beschikbaar over de jaren 1975-1976. Aangezien deze aansluiten op de trend 19491974 worden ze hier niet apart vermeld. Om zicht te krijgen op de aktiviteitenontwikkeling, die meer recentelijk plaatsvindt, is deze paragraaf voomamelijk gebaseerd op de inhoud van een aantal operationele en strategische plannen. Als vertrekpunt voor de strategische planning van het aktiviteitenaanbod van de RHA's publiceert de regering in maart 1976 het 83 bladzijden tellende rapport "Priorities for Health and Personal Social Services in England" (DHSS, 170) hierna aan te duiden als het rapport Priorities.

De uitgangspunten van het rapport zijn:

- de vraag naar zorg zal altijd groter zijn dan het aanbod: er moeten keuzen gemaakt worden.

- er is altijd een spanningsveld aanwezig tussen landelijke en plaatselijke prioriteiten.

- de richtlijnen en kaders genoemd in de "White Paper on Public Expenditure to 1979-1980" zijn gegeven.

- de prioriteiten worden aangegeven per client group, te vertalen als groepen zorgvragers. Onderscheiden worden:

1. primary care, community health and prevention

2. the general and acute hospital services and the maternity services

3 . services used mainly by the elderly and physically handicapped

4. services for the mentally handicapped

5 . services for the mentally ill

6. services for the children and families with children

7. Personal Social Services.

Voor de eerste twee groepen is de gehele bevolking de client group. De overige groepen zorgvragers spreken voor zich. Om de kosten per client group te berekenen zijn de kosten van verschillende voorzieningen samengevoegd. Zo vallen onder de kosten van "services mainly used by the elderly and physically handicapped": de geriatrie-afdeling in de ziekenhuizen, dagcentra, verpleeghuizen, wijkverpleging en chiropedie. Indien een voorziening voor meer dan één client group werkt, worden de kosten verdeeld: soms met verdeelsleutels, soms met schattingen uitgaande van op zichzelf staande voorzieningen.

Voor de periode 1975-1976 t/m 1979-1980 worden de volgende groeipercentages (van de kosten in prijzen van 1974) genoemd: de eerstelijnszorg moet groeien met 3,8\% - gezondheidscentra met $11 \%$ - in tegenstelling tot $1,7 \%$ in de eerste helft van de zeventiger jaren. Veel aandacht wordt hierbij gegeven aan de groei van de gezondheidsvoorlichting en -opvoeding en de preventie, waarvoor de regering in 1976 een aparte nota uitbrengt (DHSS, 169). Voor de algemene ziekenhuizen is het streefcijfer $0,9 \%$ in plaats van $3,7 \%$ in het begin van de jaren zeventig. De kraamzorg moet 
dalen met $1,8 \%$ in plaats van groeien met $3,8 \%$ in het jongste verleden. De zorg voor de overige groepen zorgvragers mag blijven groeien met 1 à $3 \%$, welke groei meestal wel een stuk lager is dan in de jaren 1970-1971 t/m 1973-1974 (gezondheidszorg voor bejaarden $3,2 \%$ (was $9 \%$ ) voor geestelijk gehandicapten $2,8 \%$ (was $8 \%$ ) voor psychiatrische patiënten $1,8 \%$ (was $3,6 \%$ ) voor kinderen $2,2 \%$ (was $0,5 \%$ )).

Ter aanvulling van het rapport Priorities worden ook groeinormen gepubliceerd voor de totale kosten van de RHA's. Deze normen dienen voor de planning en vormen slechts een globale aanwijzing voor de toe te kennen financiële middelen op basis van de RAWP-formule. Door het DHSS worden ook richtlijnen opgesteld voor de capaciteitsomvang voor de verschillende voorzieningen. Deze normen geven een "ideale" toestand aan en worden niet gehanteerd bij het goedkeuren van de operationele en strategische plannen. In tabel 3.4.1. worden deze laatste normen vermeld.

Tabel 3.4.1. DHSS-normen voor strategische plannen

\begin{tabular}{l|l|l}
\hline Zorgsoort & $\begin{array}{l}\text { Meeteenheid } \\
\text { van de norm }\end{array}$ & $\begin{array}{l}\text { Waarde van } \\
\text { de norm }\end{array}$ \\
\hline Algemene Ziekenhuizen & bedden per 1000 inw. & 2,8 \\
$\begin{array}{l}\text { Psychiatrische Ziekenhuizen } \\
\text { bedden per } 1000 \text { inw. } \\
\text { Verpleeghuizen }\end{array}$ & 0,5 \\
$\begin{array}{l}\text { bedden per } 1000 \text { inw. } \\
\text { van } 65 \text { jaar en ouder }\end{array}$ & 10 \\
$\begin{array}{l}\text { Verpleeghuizen voor gees- } \\
\text { telijk gestoorde bejaarden } \\
\text { bedden per } 1000 \text { inw. } \\
\text { van } 65 \text { jaar en ouder } \\
\text { Zwakzinnigen inrichtingen } \\
\text { bedden per } 1000 \text { inw. }\end{array}$ & $2,5-3,0$ \\
$\begin{array}{l}\text { Dagbehandeling in psychia- } \\
\text { trische klinieken }\end{array}$ & $\begin{array}{l}\text { aantal plaatsen per } \\
1000 \text { inw. }\end{array}$ & 0,68 \\
$\begin{array}{l}\text { Dagbehandeling in somati- } \\
\text { sche verpleeghuizen }\end{array}$ & $\begin{array}{l}\text { aantal plaatsen per } \\
1000 \text { inw. van } 65 \text { jaar } \\
\text { en ouder }\end{array}$ & 2,7 \\
$\begin{array}{l}\text { Dagbehandeling in verpleeg- } \\
\text { huizen voor geestelijk ge- } \\
\text { stoorde bejaarden }\end{array}$ & $\begin{array}{l}\text { aantal plaatsen per } \\
1000 \text { inw. van } 65 \text { jaar } \\
\text { en ouder }\end{array}$ & $2,0-3,0$ \\
$\begin{array}{l}\text { Health visiting (zuigelingen- } \\
\text { en kleuterzorg van kruisvere- } \\
\text { nigingen in Nederland) }\end{array}$ & $\begin{array}{l}\text { aantal medewerkers per } \\
1000 \text { inw. }\end{array}$ & 0,33 \\
$\begin{array}{l}\text { District nursing (overige } \\
\text { wijkverpleging in Nederland) }\end{array}$ & $\begin{array}{l}\text { aantal medewerkers per } \\
1000 \text { inw. }\end{array}$ & 0,40 \\
\hline
\end{tabular}

Bron: DHSS (178).

Noot: De norm voor de algemene ziekenhuizen wordt alleen bij nieuwbouw gehanteerd. 
Uit de interviews van dit onderzoek en de hieronder aangegeven literatuur kwamen twee hoofdbezwaren naar voren tegen het rapport Priorities.

1. Gevreesd wordt door verschillende geinterviewden, dat het rapport zal leiden tot centralisatie van de besluitvorming. Gevraagd wordt, of een District Management Team een eigen beleid mag voeren tegen het landelijk beleid in. Niet alleen de groeipercentages per client group worden vermeld, maar ook nog per voorziening nader uitgesplitst. Verschillende geïnterviewden vroegen zich hierbij af, wat de betekenis van health care planning teams kan zijn, als er toch al groeicijfers bekend zijn.

2. De lage groei en bezuinigingen van de algemene ziekenhuizen respectievelijk de kraamzorg werden in het algemeen becritiseerd. Benadrukt werd in de interviews, dat algemene ziekenhuizen ook meestal voor bejaarden werken en dat vanwege de minimale accommodatie op deze ziekenhuizen nauwelijks te bezuinigen valt. Op een congres van de British Medical Association over het rapport Priorities op 12 juni 1976 zegt Professor Booth, professor of medicine van de Royal Postgraduate School of Medicine te London: "A threadbare Peter is being robbed to pay a naked Paul" (BMA, 130, p. 1450). Over de kraamzorg wordt opgemerkt, dat de bestedingen hiervoor juist zouden moeten toenemen om de zuigelingensterfte op hetzelfde lage niveau te brengen als in andere Westeuropese landen.

Aan de hierbovengenoemde bezwaren komt het DHSS enigszins tegemoet in een rapport dat als aanvulling op het rapport Priorities in het najaar 1977 uitkomt. Dit rapport met de titel "The Way Forward" (DHSS, 178) geeft dezelfde prioriteiten aan als zijn voorganger doch minder uitgewerkt. De groeipercentages zijn verdwenen. Tevens wordt begrip getoond indien algemene ziekenhuizen worden opengehouden in verband met de vergrijzing van de bevolking. Op basis van beide rapporten zijn door de districts, AHA's en RHA's in 1977 en 1978 strategische en operationele plannen opgesteld. Deze plannen bevatten ramingen van aktiviteitenomvang, capaciteitenomvang, aantal medewerkers en aantal gebouwen. Deze ramingen zijn gebaseerd op de verwachte demografische ontwikkelingen en een inventarisatie - ook wel genoemd het health profile - van de aanwezige voorzieningen (zie East Anglian RHA, 181, Hampshire AHA (T), 194, Leicester AHA (T), 204, Southampton S.W. Hampts Health District, 237). De strategische plannen hebben meestal betrekking op een periode van tien jaar en de operationele op drie jaar.

Bestudering van de plannen van een aantal gezondheidsautoriteiten (East Anglian RHA, 181, Hampshire AHA (T), 194, Leicester AHA (T), 204, Southampton S.W. Hampts District, 237, Salisbury Health District, 235, Stockport AHA, 239) levert enkele gemeenschappelijke indrukken op.

Allereerst richten alle plannen zich op de funkties van de werkeenheden. Zo wordt er bijvoorbeeld niet gepland per algemeen ziekenhuis, maar per funktie van een dergelijke instelling. De specialismen en de paramedische afdelingen vormen dan deze funkties.

Ten tweede worden alle funktie-uitbreidingen apart opgenomen. Ze worden financieel vertaald in gevolgen voor zowel de kapitaals-als de lopende rekening. Deze gevolgen moeten worden opgevangen binnen de toegewezen middelen.

Ten derde wordt in elk van de plannen prioriteit gegeven aan de ontwikkeling van voorzieningen voor chronische zorgbehoevenden: bejaarden, zwakzinnigen en psychiatrische patiënten. De ontwikkeling hiervan zal ten koste moeten gaan van die van de algemene ziekenhuizen (Wessex RHA, 242, East Anglian $R H A, 181$ ). Ook blijkt de eerstelijnszorg in de verschillende plannen sneller te groeien dan de overige soorten zorg (East Anglian RHA, 181, Salisbury Health District, 235).

Tenslotte blijkt uit de verschillende plannen de gebrekkige huisvesting van de patiën- 
ten in de intramurale voorzieningen. De Wessex RHA zegt in de samenvatting van haar strategisch plan: "The enormous capital shortfall is, says the Plan, the Region's biggest problem. It is a shortfall which reflects part of the legacy of 1948 - a stock of largely outmoded health service buildings in Wessex. The practice of 20th Century medicine in 19th Century buildings is seen as an apt description of many parts of the Region."

De grote kritiek op de planningsmethoden, ontwikkeld door het DHSS, is gericht op het ontbreken van een voldoende relatie tussen de regionale financiering op grond van de RAWP-formule en de regionale planning. De RAWP-voorstellen hebben betrekking op één jaar. Ze gaan uit van de zorgbehoeften van de bevolking.

De regionale plannen hebben betrekking op drie dan wel tien jaar. Ze gaan uit van de aanwezige voorzieningen. De verschillen in periode-grondslag leiden ertoe dat in sommige districten operationele plannen worden opgesteld op basis van de meest waarschijnlijke toewijzing van financiële middelen als ook op basis van een of twee varianten hierop. Deze alternatieve plannen worden shadow-plans genoemd. (South Western Regional Strategic plan, 238).

Voor de langere termijn van de strategische plannen is de groei van de te verwachten financiële middelen nog minder duidelijk dan voor de periode van drie jaar. Eind 1977 , begin 1978 zijn de eerste strategische plannen op basis van het rapport Priorities gereedgekomen. In de plannen van een aantal RHA's (London NW Thames o.a.) wordt aangegeven, dat planning op langere termijn eigenlijk alleen mogelijk is als ook de groei van de te verwachten financiële middelen duidelijk is (Problems of NHS - planning, 221). Bij het ontbreken van zicht hierop krijgen de strategische plannen het karakter van een wensenlijst (Wessex RHA, 242).

De RAWP beperkt zich tot de financiering omdat zij de planning van voorzieningen een taak acht voor het management op de verschillende niveau's (Forsyth, 188). Dit houdt dan tegelijk in, dat de RAWP niet de taak heeft functie-beperkingen binnen een bepaalde regio door te voeren. Zo betekenen de voorgestelde bezuinigingen voor de Londense regio's, dat er delen van academische ziekenhuizen gesloten moeten worden. Een redaktioneel commentaar in de British Medical Journal (BMJ) zegt, dat dit laatste dan ook door het DHSS zo gesteld moet worden: "That is not a policy that the regions can be expected to push through without a lead from the top. Does the DHSS want the numbers of hospital beds (including teaching hospital beds) in London-reduced? If so, it should say so unequivocally and support the policy. If not, its proposals will inevitably lead to a remorseless drain of resources and morale from London's medicine, to the detriment of the whole country" (What a RAWP roar, 246). Dezelfde kritiek kwam in dit onderzoek van de kant van veel geinterviewde personen naar voren. Tijdens een bezoek aan de Londense health area, Hammersmith, Hounslow and Ealing, met één van de hoogste budgetten per hoofd van de bevolking in Engeland, werd het volgende opgemerkt: "De SIFT gaat uit van de gemiddelde kosten per student in Engeland. Vrijwel alle Londense academische ziekenhuizen liggen boven en alle niet-Londense beneden dit gemiddelde. Er is niet uitgezocht waarom dit zo is. Het is de vraag of de Londense academische ziekenhuizen zo inefficiënt werken. Een bezuiniging op het onderwijsbudget kan alleen betekenen het samenvoegen, sluiten of verhuizen van academische ziekenhuizen naar andere regio's. De regering geeft evenwel niet aan in haar onderwijsbeleid, of ze medische faculteiten wil sluiten. Dit laatste regelt het ministerie van onderwijs en niet de gezondheidsautoriteiten".

Verschillende geinterviewden en onderstaande auteurs wijzen erop, dat academische ziekenhuizen in het algemeen en in Londen in het bijzonder nogal wat nieuwbouw in de jaren zestig hebben neergezet (zie ook par. 2.4.1.). Ook heeft er in het verle- 
den relatief veel nieuwbouw plaatsgevonden voor geestelijk gehandicapten en voor inwoners van nieuwe steden, (Godber, 191, Gentle, 189 en Rathod, 222). Het gaat dan niet aan een paar jaar later een financiering te ontwerpen, die niet aansluit op het gevoerde beleid in het verleden. Nog groter worden de problemen bij de financiering van de health districts en AHA's uit de financiële middelen van de RHA's. Verscheidene auteurs wijzen erop, dat de verschillen tussen AHA's groter zijn dan die tussen regio's. Buxton en Klein (137) geven aan, dat de per capita exploitatiebudgetten voor de regio's verschillen van $+41 \%$ tot $-23 \%$ van het gemiddelde. In hun onderzoek zijn de percentages voor de AHA's + 62\% en - 69\% (zie ook Richard, 224 en 225).

Door funktionarissen in bezochte AHA's en districts werd gesteld, dat de beslissingen om budgetten van de ene naar de andere area of district binnen een regio over te boeken bijzonder moeilijk is. Immers op AHA en health district niveau moeten verschuivingen van budgetten worden vertaald in verschuivingen van aktiviteiten, gebouwen en arbeidsplaatsen. Vanwege de vaste kosten-struktuur van de werkeenheden werden in verschillende bezochte distrikten in Londen, Wessex Region en Trent Region juist de verschuiving van de gebouwen en arbeidsplaatsen onuitvoerbaar geacht op korte termijn. Verder bleek, dat de landelijke prioriteiten neergelegd in het rapport Priorities wel werden gedeeld, maar dat de groeipercentages en de indeling in client groups nauwelijks te hanteren waren in verband met het ontbreken van een voldoende afgestemde kosteninformatie.

$\mathrm{Om}$ de verschillen in vertrekpunt tussen de financiering en de planning te overbruggen is de RAWP-formule landelijk slechts gedeeltelijk ingevoerd (zie paragraaf 3.4.3.2.). Uit gesprekken in de Wessex RHA, die in Engeland wordt beschouwd als een van de regio's met een zeer ontwikkeld planningssysteem, kwam naar voren dat de financiêle middelen sinds 1978-1979 door de RHA worden toegewezen naar de areas en districts op basis van de inhoud van de strategische plannen en de relatieve zorgbehoeften. Hierdoor wordt door deze RHA getracht de uitgangspunten relatieve zorgbehoeften en aanwezige voorzieningen te integreren (zie ook: Royal Commission on the NHS, 230, p. 100 e.v.).

\subsubsection{Afremming kostengroei}

In tabel 3.4.2. wordt de kostenontwikkeling aangegeven van de NHS van het Verenigd Koninkrijk. De gegevens sluiten niet aan op die in tabel 2.4.2., aangezien hier wordt uitgegaan van kalenderjaren en in tabel 2.4.2. van financiële jaren. De gegevens hebben betrekking op de periode 1970-1978, zodat ook een aantal jaren voor de reorganisatie in 1974 in ogenschouw kunnen worden genomen.

De geschatte kosten in 1978 bedragen $£ 8$ mld., ofwel $£ 141,3$ per inwoner. Ze zijn in dat jaar meer dan het dubbele van die in 1974 en het viervoudige van die in 1970. Deze kostenstijging hangt nauw samen met de inflatie: gemeten in constante prijzen zijn de kosten in 1978 slechts $8 \%$ hoger dan die in 1974. Ten opzichte van 1970 is dat percentage $44 \%$. Als percentage van het BNP liggen de kosten van de NHS sinds 1975 op het niveau van 5,7 à $5,8 \%$. In de periode 1970-1974 varieert dit percentage tussen 4,7 en $5,2 \%$.

De bevinding in hoofdstuk 3 dat de kostenontwikkeling van de NHS wordt afgeremd en bepaald door het politieke afwegingsproces van de Britse regering en het Britse parlement wordt door de volgende feiten ondersteund. De Labourregering, die in maart 1974 aan het bewind kwam, gaf expliciet prioriteit aan huisvesting en pensioenverhogingen boven gezondheidszorg en onderwijs. Deze regering handhaafde de bezuinigingen van de vorige regering. De White Paper van januari 1975 bracht het groeipercentage van de kosten van de NHS terug van $3,5 \%$ naar $2,7 \%$ over de pe- 


\begin{tabular}{|c|c|c|c|c|c|c|}
\hline \multicolumn{7}{|c|}{ totale kosten NHS } \\
\hline jaar & \multicolumn{2}{|c|}{$\begin{array}{l}\text { absoluut } \\
\text { bedrag } \\
\text { in mld. } £\end{array}$} & \multirow{2}{*}{$\begin{array}{l}\text { als } \\
\text { percentage } \\
\text { van BNP } \\
4,1 \\
4,7 \\
4,8 \\
4,9 \\
4,8 \\
5,2 \\
5,7 \\
5,7 \\
5,8^{*} \\
5,7 *\end{array}$} & \multirow{2}{*}{$\begin{array}{l}\text { per } \\
\text { inwoner } \\
\text { in } £\end{array}$} & \multicolumn{2}{|c|}{$\begin{array}{l}\text { in prijzen } \\
\text { van } 1949 \\
\text { in mld. } f\end{array}$} \\
\hline $\begin{array}{l}1965 \\
1970 \\
1971 \\
1972 \\
1973 \\
1974 \\
1975 \\
1976 \\
1977 \\
1978\end{array}$ & $\begin{array}{l}1,3 \\
2,1 \\
2,4 \\
2,7 \\
3,1 \\
3,9 \\
5,4 \\
6,3 \\
7,1 * \\
8,0^{*}\end{array}$ & $\begin{array}{r}33 \\
54 \\
62 \\
69 \\
79 \\
100 \\
138 \\
162 \\
182 \\
205\end{array}$ & & & $\begin{array}{l}0,7 \\
0,9 \\
0,9 \\
1,0 \\
1,1 \\
1,2 \\
1,3 \\
1,3 \\
1,2 \\
1,3\end{array}$ & $\begin{array}{r}58 \\
75 \\
75 \\
83 \\
92 \\
100 \\
108 \\
108 \\
100 \\
108\end{array}$ \\
\hline
\end{tabular}

Bron: OHE, OHE Briefing, no. 7, October 1978.

* betekent: schatting.

riode 1974-1979 (Chancellor of the Exchequer, 139), terwijl de investeringen werden teruggedraaid tot het niveau van het eind van de jaren zestig. In april 1975 bleek echter dat ook deze streefcijfers niet gehaald konden worden. Verwacht werd dat de lopende bestedingen voor 1976-1977 1 à 1,5\% zouden kunnen toenemen en dat de investeringen met $10 \%$ zouden moeten afnemen. In feite betekenden deze groeicijfers dat de kwaliteit van de zorg nauwelijks te handhaven was. Uitgerekend was, dat 1 à $2 \%$ groei van het exploitatiebudget nodig was om de doorwerking van reeds gedane investeringen en de zorgtoename ten gevolge van de veroudering van de bevolking op te vangen. Het toegestane jaarlijkse investeringsplafond was net genoeg om de reeds begonnen bouw af te maken en hoogst noodzakelijke, geringe verbouwingen in bestaande voorzieningen te verrichten. Nieuwbouw werd verder voor de komende jaren uitgesloten (zie uitvoerig Brown, 110). In februari 1976 publiceerde de Britse regering de "White Paper on Public Expenditure voor 1979-1980" (Chancellor of the Exchequer, 140). Omdat in deze White Paper het beleid wordt geformuleerd, dat in de White Papers van 1977 en 1978 wordt voortgezet, volgt hieronder een samenvatting van hoofdstuk II "Health and Personal Social Services" van deze nota. Aan de health and personal social services wordt over de periode 1975$1976 \mathrm{t} / \mathrm{m}$ 1979-1980 toegestaan een groei van circa 1,5\% van de kosten, gemeten in prijzen van 1975. Dit groeipercentage is opvallend te noemen tegen de achtergrond van het afnamepercentage over dezelfde periode voor verschillende andere departementen zoals onderwijs. Wel is de kostengroei van de gezondheidszorg en de maatschappelijke dienstverlening afgeremd ten opzichte van vorige jaren en ten opzichte van plannen uit vorige White Papers. In the White Paper wordt gesteld dat het groeipercentage van $1,5 \%$ voldoende moet zijn om de tegenwoordige zorgstandaarden te handhaven voor de gehele bevolking, rekening houdende met een snelle groei van het aantal bejaarden. Over de cash-limits (zie par. 2.1.1.) voor de health and personal social services is het volgende op te merken. Vanaf 1976-1977 wordt het de gezondheidsautoriteiten toegestaan in geval van begrotingsonderschrijding een bedrag van maximaal $1 \%$ - in plaats van de $0,25 \%$ voor 1975-1976 - van de lopende uitgaven 
over te boeken naar het volgende boekjaar. Een begrotingsoverschrijding wordt afboekt op de begroting van het volgende financiële jaar. Verder wordt het de gezondheidsautoriteiten toegestaan $1 \%$ van hun lopende uitgaven aan te wenden als kapitaalsinvesteringen. Andersom geldt, dat maximaal $20 \%$ van de toegestane gelden op de kapitaalrekening overgeboekt mag worden naar de exploitatierekening.

Aangekondigd wordt in de White Paper een Consultative Document, waarin de prioriteiten voor health and personal social services nader worden aangegeven (zie par. 3.3.1.). Tevens wordt gesteld dat de herverdeling van de toe te wijzen financiële middelen - resource allocation - en het doen verminderen van de particuliere bedden in NHS-ziekenhuizen binnen de aangegeven begroting dienen plaats te vinden. Op 22 juli 1976 kondigde de Britse minister van financiën een bezuiniging aan op de overheidsuitgaven in het jaar 1977-1978. Deze hield in een bezuiniging van $£ 70$ $\mathrm{mln}$. voor de gezondheidszorg. Deze zou moeten worden bereikt door het verhogen van de eigen bijdrage voor tandartsen en oogartsenzorg ( $£ 20 \mathrm{mln}$.), en het verlagen van de kapitaalsuitgaven van $£ 354 \mathrm{mln}$. naar $£ 334 \mathrm{mln}$. Op centraal gefinancierde voorzieningen wordt verder $£ 10 \mathrm{mln}$. bezuinigd. Tenslotte en zeer opmerkelijk worden de kosten van gezondheidszorg, veroorzaakt door verkeersongelukken, voortaan betaald uit motorrijtuigenverzekeringen: $£ 20 \mathrm{mln}$. of $£ 3$ per gemotoriseerde verkeersgebruiker. Op het voorzieningenpeil in zijn geheel wordt niet bezuinigd. De White Papers volgend op de bovenstaande van 19 februari 1976, die van het voorjaar 1977 en 1978 (Chancellor of the Exchequer, 141,142) zijn te zien als een continuering van het in 1976 ingezette financiële beleid. De cash-limits blijven gehandhaafd alsmede het groeipercentage van 1 à $2 \%$, gemeten in constante prijzen, waardoor de kwaliteit van de gezondheidszorg nog net gehandhaafd kan blijven.

Tijdens de reizen bleek de noodzaak van het afremmen van de groei van de NḦS door de meeste geinterviewden te worden ingezien. Er kwam een zekere bewondering naar voren voor Barbara Castle, de bewindsvrouw op het DHSS vanaf begin $1974 \mathrm{t} / \mathrm{m}$ begin 1977, die een daling van de kosten van haar departement wist te voorkomen. De vraag rijst hierbij op, of deze kostenverandering uitsluitend op een sterke bewindsvrouw is terug te voeren. Te wijzen is ook op een toename van het management in 1975 en de daarmee gepaard gaande kosten van de NHS-autoriteiten. Om deze toename te beteugelen gaf Barbara Castle in 1976 op aandringen uit het Lagerhuis de opdracht aan deze autoriteiten om plannen te maken ter vermindering van de managementkosten met 10\% (DHSS, 165). Zowel uit dit soort maatregelen als uit de beleidsformulering in de White Papers lijken de opvattingen en beslissingen van regering en parlement van grote invloed te zijn op de ontwikkeling van de totale kosten van de NHS. Door de afwegingsprocessen van het DHSS ten opzichte van andere departementen en het totaal van de Rijksbegroting wordt deze ontwikkeling afgeremd. Hoe deze beslissingen op nationaal niveau uiteindelijk het gedrag van de individuele arts beinvloeden staat voor de periode vóór 1974 beschreven in par. 2.4.1. Dit beinvloedingsproces is na de reorganisatie niet veranderd. Voor de arts zijn alleen de instanties tussen hem en het DHSS veranderd: er wordt geen limiet gesteld aan de door de arts te verrichten aktiviteiten. Wel is hij afhankelijk van de door de DMT beschikbaar gestelde accommodatie en medewerkers. Aan de kosten van middelen, die direkt samenhangen met het medisch handelen, zoals kosten van medicijnen, verband en infusen wordt evenmin een limiet gesteld. Overschrijding van de budgetten hiervoor, die relatief klein zijn in verhouding tot het totale kostenbudget van het DMT, wordt meestal gecompenseerd tegen overschotten van andere budgethouders. Meestal is dit een voldoende oplossing. Indien dat niet het geval is, worden de uitgaven op andere kostensoorten afgeremd door bijvoorbeeld vakatures iets langer open te laten. De DMT ontvangt zijn budgetten, zoals gezegd via 
de AHA's en RHA's van het DHSS. Begrotingsoverschrijding van deze instanties worden in het volgende jaar gekort op het toegewezen budget (zie ook: Royal Commission on the NHS, 230, p. 108 en 109).

\subsubsection{Evenwichtige geografische spreiding*}

In grafiek 3.4.3. is aangegeven, hoe de feitelijke RAWP-financiering zich over de financiële jaren 1975-1976 tot en met 1979-1980 ontwikkelt. Zoals gezegd vallen deze buiten deze financiering. De overige voorzieningen worden wel via de RAWP-formule gefinancierd. In grafiek 3.4.3. worden de RAWP-uitkeringen per RHA aangegeven als een indexcijfer. Een indexcijfer van 110 betekent dat de uitkeringen er per inwoner $10 \%$ hoger zijn dan in geheel Engeland het geval is. Af te lezen is dat er sprake is van een naar elkaar toegroeien van de verschillende RHA's. Dit proces van naar elkaar toegroeien verloopt niet zonder moeilijkheden, hoewel de doelstellingen van de RAWP-formule wel in brede kring worden onderschreven, aldus het eindrapport van de RAWP (DHSS, 173, p. 95).

Grafiek 3.4.3. RAWP-uitkeringen aan RHA's per hoofd van de bevolking in procenten van het national gemiddelde

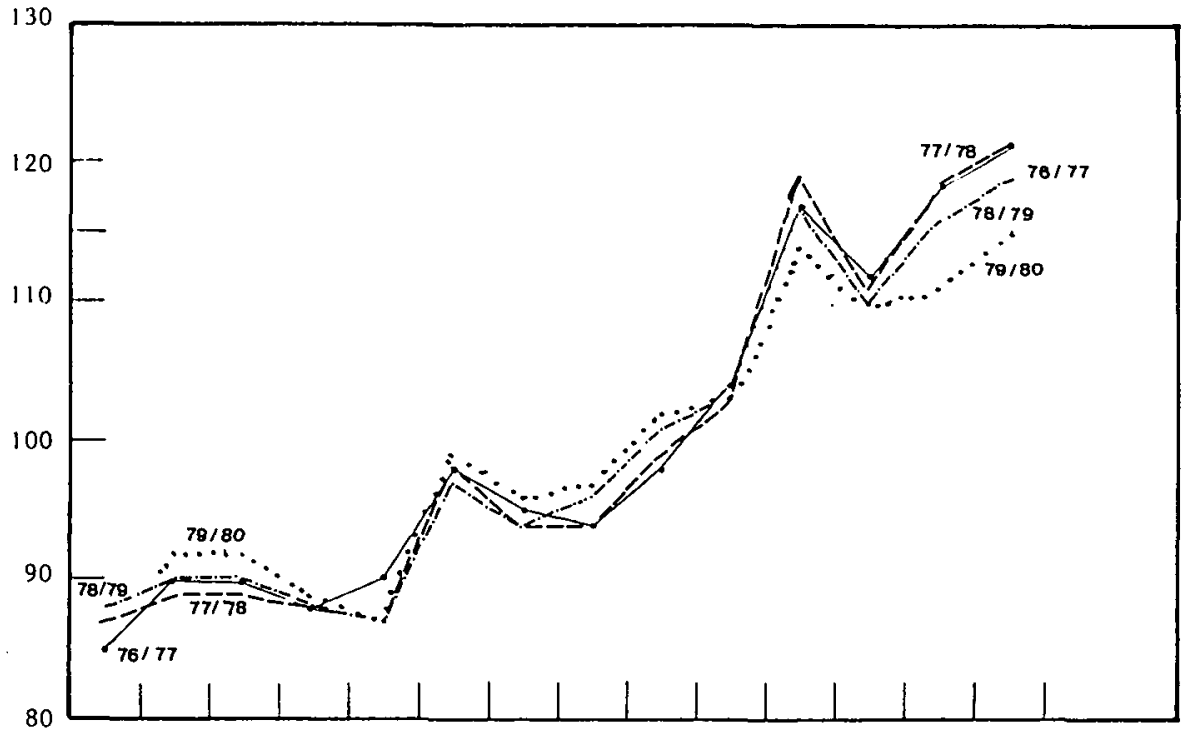

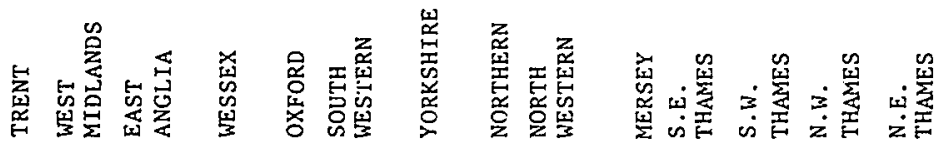

Bron: Allocations to RHA's 1977/78 (120), Cash limits for health authorities (161), DHSS (171), Next year's Money for the NHS (213), OPCS-Monitor (216).

* Aangezien bij het afsluiten van het onderzoek onvoldoende gegevens beschikbaar waren van aktiviteiten en arbeidsplaatsen per RHA wordt volstaan met de regionale verdeling van de RAWP-uitkering. 
De kritiek en problemen met de RAWP-formule-financiering zijn in de afgelopen jaren van drieërlei aard geweest.

1. het ontbreken van een relatie met de planning van voorzieningen.

2 . het ten onrechte hanteren van een aantal van de kriteria.

3 . het te snel willen invoeren van de RAWP-formule.

De eerste kritiek is in paragraaf 3.4.1. aan de orde gekomen. Hieronder worden de beid ndere punten besproken.

\subsubsection{Kritiek op de gebruikte kriteria van de RAWP-voorstellen}

De kritiek op de gebruikte kriteria is van drieërlei aard. Ze richt zich op het hanteren in de formule van ten eerste zorgbehoeften en van ten tweede geografische gebieden. Daarnaast wordt ten derde op elk van de kriteria afzonderlijke kritiek geleverd.

\section{ad 1. Alleen zorgbehoeften in de formule}

Verschillende geinterviewden op universitaire instituten, vroegen zich af, of ook niet de kosten voor het wegnemen van de oorzaken van dit beddengebruik zouden moeten worden meegenomen. Slechte huisvesting in Londen, kan een reden zijn voor extra-budgetten. Het effekt, dat méér zorgaanbod leidt tot een geringere zorgbehoefte is nauwelijks aan te tonen. Het is dan de vraag of méér zorgbehoefte moet leiden tot meer zorgaanbod of tot maatregelen om de zorgbehoefte op zich te verminderen. Wellicht moeten de kosten van het wegnemen van de oorzaken van het gebruik van gezondheidsvoorzieningen eerder gemaakt worden op andere departementen. Door de RAWP blijft de vraag onbeantwoord, hoe binnen de gezondheidszorg de prioriteiten te stellen. Immers de RAWP stelt, dat de zorgbehoeften het zorgaanbod zullen overtreffen (DHSS, 173, p. 7). Een methode om de gezondheidszorg binnen het gestelde budget objectief te rantsoeneren rationing health care geeft de RAWP niet. Slechts het hanteren in de formule van een aantal client-groups geeft enige houvast voor de verdeling.

ad 2. Geografische gebieden en de RAWP-formule

Als doelstelling van de RAWP wordt in het eindrapport geformuleerd: "to secure, through resource allocation that there would eventually be equal opportunity of acces to health care for people at equal risk" (DHSS, 173, p. 7). De RAWP heeft deze doelstelling vertaald in een streven naar gelijke bestedingen per inwoner en per gebied. "Equal opportunity of acces to health care" is echter ook te vertalen als gelijke reistijden voor patiënten naar hun voorzieningen. De consequenties van deze andere benadering zijn groot. Ten eerste zou deze laatste benadering kunnen inhouden, dat de Londense RHA's meer geld ontvangen vanwege de relatief korte reistijden vanuit het gehele land. Ten tweede zouden dunbevolkte gebieden meer middelen ontvangen om relatief kleine voorzieningen dichtbij de bevolking te brengen (zie ook R. Klein, 200).

ad 3. Kritiek op gebruikte kriteria

In het eindrapport van de RAWP wordt de gezondheidszorg verdeeld in zeven soorten. Voor elk van deze soorten wordt de bevolking apart gewogen. Verschillende geïnterviewden geven het belang aan van het op deze wijze indelen van zorgbehoefte. Alleen op deze wijze is het schatten te verfijnen van het aantal mensen onder de bevolking met een bepaalde zorgbehoefte (zie ook West, 245, Jones, 197). Grote negatieve kritiek wordt geuit op het gebruiken van SMR's als kriterium voor de morbiditeit onder de bevolking en het ontbreken van een faktor voor de sociaal-economische struktuur (What a RAWP roar, 246, Jones en Bourne, 197, Wessex RHA, 243, Dixon, 179, Jones, 198 en Fair Shares, 186). Vanwege de 
bezwaren tegen het gebruik van SMR's pleiten Jones en Bourne (197) voor een onderzoek naar de toepasbaarheid van enquêtegegevens van de General Household Survey als kriterium voor de morbiditeit. De Wessex RHA hanteert in het jaar 19761977 een toewijzingsformule, waarin naast de mortaliteit ook gebruikt worden de self reported chronic sickness episodes en de self reported acute sickness episodes. Deze gegevens zijn afkomstig uit de genoemde General Household Survey. De bevolking wordt dan voor elk van beide kriteria en voor de mortaliteit gewogen (Wessex $R H A, 243$ ). Grote kritjek wordt ook geleverd op het ontbreken in de RAWP-formule van een factor voor de sociaal-economische struktuur, waaronder valt de struktuur van de werkgelegenheid, de bevolkingsdichtheid en de huisvesting. In zijn eindrapport stelt de RAWP, dat het opnemen van zo'n factor niet nodig is, indien de morbiditeit van de bevolking rechtstreeks gemeten wordt (DHSS, 173, p. 15). Deze stelling is op zich juist, indien de morbiditeit volledig wordt gemeten. Hierboven is evenwel aangegeven, dat het hanteren van SMR's als kriterium voor de morbiditeit een nogal heroische veronderstelling is. Wie kritiek heeft op de SMR's mist meestal een factor voor de sociaal-economische struktuur (zie ook Dixon, 179, Jones, 198, Fair shares, 186). De pleidooien voor een factor voor de sociaal-economische struktuur zijn evenwel nauwelijks statistisch onderbouwd. Ze zijn meestal gericht op meer financiële middelen voor de grote steden.

Detailkritiek wordt verder én in de interviews, én in de literatuur geleverd op de volgende punten.

- Het is de vraag of de kosten van het behandelen van de regiogrens-overschrijdende patiënten (zie Jones, 197 en 199) niet hoger zijn dan het gemiddelde in het betrokken specialisme, zoals de RAWP stelt. Waarschijnlijk zullen juist de moeilijke patiënten worden doorgezonden vanuit de regio's naar de centres of excellence in Londen (Joules, 199).

- Voor de distriktgrenzen-overschrijdende patiëntenstroom geldt nog, dat de kosten per behandelde patiënt niet bekend zijn. Deze zijn andere dan die van de regio. Specialismen als neurochirurgie, thoraxchirurgie, radiotherapie, die binnen een regio vaak in één of twee centra zijn geconcentreerd, zullen vooral patiëntenstromen tussen distrikten veroorzaken. Het bepalen van de kosten per geval van deze specialismen moet echter nogal arbitrair gebeuren vanwege gebrek aan informatie.

- De veronderstelling, dat kosten van de behandeling per dag van psychiatrische patiënten overal in het land gelijk zijn, is nogal grof: "This has the advantage of averaging out the financial cost but is fairly crude, because psychiatric hospitals costs can vary significantly depending, for example, on the amount of acute psychiatry being carried out compared to longstay work, and on the size of hospital being dealt with" (Dixon, 179, p. 216).

- Een belangrijke vraag is tenslotte, hoe de individuele arts en hulpverlener in een regio zal reageren op de RAWP-formule. Zal hij de gestelde prioriteiten accepteren? Peter West pleit voor een diepgaand onderzoek naar het medische gedrag, zodat hiermee in een toewijzingsformule rekening kan worden gehouden (West, 244, p. 30). De redaktie van de British Medical Journal beschouwt de case-loadfactor in het RAWP-interim rapport, als een prikkel voor het medische handelen. Gentle en Forsy the (189) stellen, dat efficiënter werken wordt gestimuleerd, indien een District Management Team de gerealiseerde besparingen zelf opnieuw mag aanwenden (zie ook: Royal Commission on the NHS, 230, p. 119 e.v.).

\subsubsection{Te snel uitvoeren van de RAWP-voorstellen}

In zijn eindrapport geeft de RAWP aan, dat de bezuinigingen per jaar voor een beter 
bedeelde regio hooguit $2,5 \%$ mogen bedragen. De maximale groei per jaar voor een minder bedeelde regio stelt de RAWP op 5\% (DHSS, 173, p. 29). Dit voorstel betekent dat de Londense regio's jaarlijks moeten bezuinigen. Het is duidelijk dat het overnemen van zo'n voorstel voor een minister van gezondheidszorg een moeilijke beslissing is. Het interim-rapport van de RAWP stelt dan ook in zijn konklusies (DHSS, 162, p. 15): "A change of this order is dependant absolutely on the ability, particularly in those regions suffering a reduction in their allocations, to carry into effect a rationalization program involving substantial closures of uneconomic units, reductions in excess beds, changes of use etc. In encouraging this approuch, we cannot emphasis enough that rationalization of the order envisaged will be illusory unless Ministers are prepared to take a resolute stand when politically sensitive cases or those which are otherwise contested, for example, by CHC's are presented for decision".

Ook constateert de RAWP (DHSS, 173, p. 47): "There is no escaping the fact, that one centre's 'excellence' may be bougth at the price of another's 'deprivation'". Het is de vraag, of de macht van het DHSS zo groot is, dat de herverdeling van financiële middelen kan worden doorgevoerd. De politieke partijen hebben immers ook kiezers in Londen. De medische professie heeft zijn lobby-isten uit Londen in het parlement. Hieraan is de stelling van Machiavelli toe te voegen, dat diegene die iets moet afstaan met zijn protesten altijd het gejuich van degene die ontvangt $z a l$ overstemmen. Een niet-populaire beslissing veronderstelt minstens een acceptatie ervan door alle betrokkenen, ook indien men er niet akkoord mee is. Gelet op de reeds bestaande onvrede bij medici in de NHS, kan betwijfeld worden of deze acceptatie wel aanwezig is. Rudolf Klein stelt in ieder geval: "If the Government's policy of redistributing resources aim is to be taken seriously it follows that a necessary first step is to create conditions designed to encourage the acceptance of change, whether by retraining programmes, compensation payments, or larger grants for people who have to move to a different part of the country.

Redistribution is about lost jobs and shattered expectations, and no policy which fails to take account of this likely to succeed, - or, indeed, to be implemented by a Secretary of State who, naturally enough, will want to avoid cutting his own political throat" (Klein, 201). Crossman, die in 1968 als eerste Minister of Health een aanzet maakte tot een rechtvaardige verdeling van de gezondheidszorg over Engeland, wijst in zijn boek op de politieke moeilijkheden van een herverdeling:

"Unless the Health Service budget rises steadily, and unless the percentage of the GNP alloted to it is steadily increased. I cannot level up the bad regions to the better regions and the gap remains" (Crossman, 157, p. 13).

Verschillende geinterviewden gaven eveneens aan, dat het verlagen van de uitkeringen aan de rijkere, Londense regio's politiek gezien een moeilijke beslissing is. De vakbonden, de professie en de publieke opinie keren zich tegen voorgenomen ziekenhuissluitingen. De medische professie is individualistisch en komt op voor haar lokale belangen. De publieke opinie richt zich via de CHC's in de betrokken areas meer op sluiting van ziekenhuizen dan op de groei in andere regio's. In landelijke kranten als The Times en The Guardian verschijnen stukken over de mogelijke sluiting van 2000 ziekenhuisbedden in Londen ten gevolge van de RAWP-voorstellen (zie grafiek 3.4.3.2.) (Fear of further hospital cut back, 185). Behalve deze politieke moeilijkheden bij het invoeren van de RAWP-formule zijn ook andere meer technische, factoren te noemen die vertragend werken. Te noemen zijn:

- afbouw van voorzieningen kost op zich geld, dat bij een lage toewijzing van financiële middelen niet aanwezig is.

- het is bijzonder moeilijk medici te laten verhuizen naar de regio's die mogen 
groeien. Dit blijkt reeds uit de problemen met het negatief vestigingsbeleid voor huisartsen (zie par. 2.3.3.). Hier tegenover staat de opvatting dat betere voorzieningen in de arme regio's vanzelf ook betere artsen zullen aantrekken.

- bij een macro-economische teruggang moet geen kapitaal (= ziekenhuisbedden) vernietigd worden om elders duur opnieuw op te bouwen. Het is de vraag of met het bespaarde geld in de Londense regio's evenveel nieuwe voorzieningen elders opgebouwd kunnen worden.

Over de politieke en technische moeilijkheden om te bezuinigen in Londen en in de Mersey Region is en wordt uitvoerig gediscussieerd in de vakbladen en in het parlement (zie onder andere Brown, 133, Jones, 198, Forsythe, 180, Rippington, 226, Joules, 199 en Dyson, 180).

In feite is de RAWP-formule slechts gedeeltelijk ingevoerd. Geen enkele regio heeft hoeven te bezuinigen. De groeipercentages vanaf 1976-1977 tot heden variëren steeds van 0 tot $3 \%$. Op dit moment staat zelfs de verdere invoering op korte termijn van de RAWP-formule op de tocht door grote moeilijkheden in Liverpool (Dyson), waar een groot deel van de ziekenhuizen in zijn voortbestaan werd bedreigd. In de Oxford RHA worden in 1978 vijf ziekenhuizen gebouwd, die zonder extra-financiering niet geopend kunnen worden (Jeffries, 196). Eind 1978 is een Londense AHA, waarin zich drie beroemde teaching hospitals bevinden, een open confrontatie aangegaan met het DHSS door op de oude voet te blijven besteden (DHSS, 168).

De uitkomst van deze principestrijd is medio 1979 nog niet bekend $(D H S S, 168)$. Wel wordt de invoering van de RAWP-formule meer en meer op de lange baan geschoven. David Ennals had reeds gezegd eind 1976, dat deze invoering meer dan tien jaar zou duren. In het voorjaar 1978 wordt door de Minister of Health gesproken over het toepassen van de RAWP-formule als lange termijn doel (Confusion as Moyle tells of RAWP. Gloom, 146). In een studie verricht voor de Royal Commission on the NHS (229), wordt dit ook zo gezien.

Grafiek 3.4.3.2. Bericht uit The Guardian van 27 november 1976, pag. 1

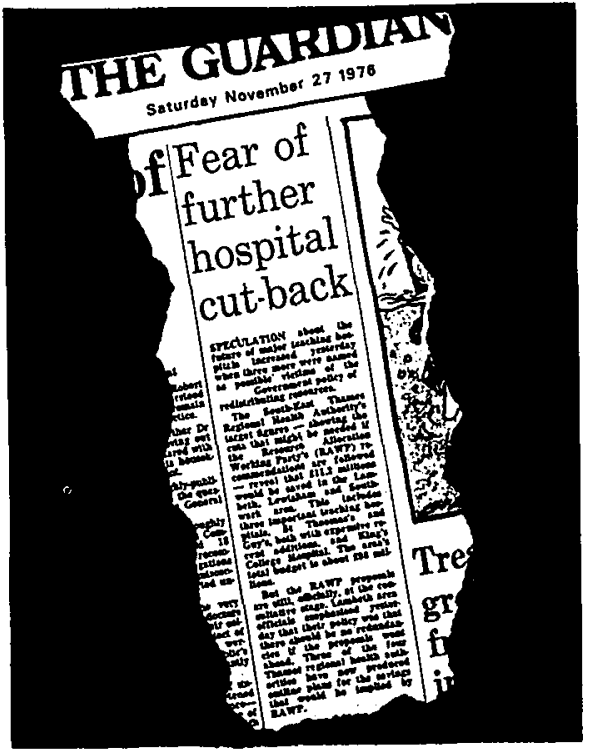


Op te merken is, dat de RAWP-voorstellen wel hebben meegewerkt aan het verschuiven van het machtsevenwicht. De voorstellen maakten de positie van de rijkvoorziene regio's zwakker, brachten ze in een verdedigende positie, en versterkten de claims van de minderbedeelde regio's. Het uitbrengen van de vergaande RAWP-adviezen bracht de regering in de gemakkelijke positie te kiezen tussen het advies en de invloed van rijkere regio's. Door dan een tussenweg te kiezen kregen én de rijkere regio's én de RAWP het gevoel iets bereikt te hebben en wordt de politieke beslissing gemakkelijker geaccepteerd. In wezen is deze wijze van werken een vorm van verdeel- en heerspolitiek.

Desgevraagd deelde het DHSS mede, dat de RHA's zich wel aan de toegestane groeipercentages over 1977-1978 hebben gehouden. Voor AHA's is dit vrijwel altijd (zie boven) het geval, Over districten zijn geen gegevens bekend. Met name het bestaan van de cash-limits lijkt een belangrijke overweging te zijn geweest om binnen het groeiplafond te blijven.

\subsubsection{Integratie zorgverlening}

De belangrijkste overweging voor de reorganisatie van de NHS was de integratie van bestuur op lokaal niveau. Deze integratie krijgt nu gestalte op districtsniveau door eenheid van bestuur en eenheid van financiering voor de verschillende werkeenheden. Tijdens interviews en het toehoren van DMT-vergaderingen in distrikten in Londen, Manchester, Leicester en Southampton is meer dan eens de vraag naar voren gekomen of er al positieve resultaten merkbaar waren op het gebied van de integratie van het beleid. Uit de antwoorden in de interviews en de indrukken uit vergaderingen kwam naar voren dat de integratie vooral gestalte krijgt in de gemeenschappelijke planning. Bij dit laatste is te denken aan de planning van aktiviteiten per client-group, het opstellen van de begroting, de personeelsplanning en de bestemming van de in het distrikt aanwezige gebouwen. Uit de bezoeken bleek, dat de planning werd voorbereid en vastgesteld door de leden van het DMT zelf. Aparte planningsafdelingen bestonden niet in de genoemde distrikten. Plannen voor bepaalde voorzieningen en funkties werden opgesteld onder leiding van de eerstverantwoordelijke leden van het DMT. Deze integratie van dagelijks bestuur en planning wordt ook bepleit in een onderzoek, dat de Oxford RHA door een speciale commissie liet verrichten naar de management funkties binnen de eigen RHA. Deze commissie moest uitzoeken, hoe in 1976 op de management funkties $10 \%$ bezuinigd kon worden, zoals aan alle RHA's gevraagd was door de Secretary of State (zie paragraaf 3.4.3.). Na gesprekken met alle elf management teams binnen de Oxford Region en met 70 individuele personen kwam deze commissie tot de bevinding, dat het aantal speciale planners klein zou moeten blijven, maar dat planning een taak hoort te zijn van het management. Verder komt deze commissie tot de - in paragraaf 2.4.1. genoemde - conclusie, dat planning en financiering geïntegreerd horen te zijn (Oxford RHA, 219, p. 22).

Gevraagd naar andere effekten van de integratie van de zorgverlening werd in verschillende distrikten nogal eens de veranderde positie van de extramurale zorgverlening genoemd. $V$ an deze sektor zitten nu twee vertegenwoordigers in het DMT. Hierdoor is een grotere inbreng voor deze sektor gewaarborgd.

Een onderzoek, verricht door een team van de Brunel University en medio 1978 gepubliceerd, gehouden onder 500 managers van de NHS, komt tot een overeenkomstige voorlopige bevinding (134, p. 228), die samengevat luidt: als resultaat van de integratie lijkt - zo hebben de geinterviewden het gevoel - het ziekenhuis iets minder ver te staan van de maatschappelijke gezondheidszorg. De bestaande geïsoleerde positie van de family practitioners blijft een groot probleem. Dit laatste is echter 
niet zo zeer op te lossen door veranderingen in de organisatiestruktuur maar door veranderingen in waarden en opvattingen.

Positief werd ook in een aantal distrikten ervaren het bestaan van health care planning teams. Deze teams maken onder leiding van de District Community Physician een integraal plan voor een bepaalde client group. Deze teams zijn multidisciplinair samengesteld en telden leden uit verschillende echelons. Wel werd in onder andere Southampton S.W. Hampts District opgemerkt dat het moeilijk is teamleden gemotiveerd te houden, indien zeer weinig van de gemaakte plannen financieel wordt gehonoreerd.

Behalve deze positieve punten heeft de geintegreerde struktuur een aantal knelpunten opgeleverd dan wel laten bestaan. Deze betreffen het aantal managementniveau's, de samenwerking met de maatschappelijke dienstverlening, en de coördinatie binnen een ziekenhuis. Als knelpunt van de nieuwe struktuur werd in elk interview opnieuw genoemd dat er één organisatieniveau teveel is: "one tier too many".

Overeenstemming bestaat er over dat de NHS één centraal orgaan voor het algemene beleid en vele operationele organen voor het dagelijkse management nodig heeft. Tussen deze twee is dan één planningsniveau nodig voor regionale planning op langere termijn. Deze opsomming leidt slechts tot drie managementniveau's. De vraag is dan welke van de vier bestaande niveau's moet verdwijnen.

In de interviews werd vooral gepleit voor oplossingen afgestemd op plaatselijke omstandigheden. Met name kwam hierbij de voorkeur naar voren tot samenvoegen van health districts en AHA's. Dit kon soms betekenen het opheffen van de eerstgenoemden en soms het creëren van meer AHA's. Recentelijk blijkt deze laatste opvatting de overhand te krijgen. Zo zijn in 1978 de health districts in Sheffield samengevoegd tot één single district area (zie Another Area cuts a district, 123).

Het is de vraag, of hierdoor alle problemen over de taakafbakening tussen de managementniveau's worden opgelost. Ook de relatie tussen het departement en de NHS levert frikties op. De veertien voorzitters van de RHA's wijzen in een gezamenlijk rapport hierop: "The Department has in consequence grown steadily in size in recent years, to the detriment of its effectiveness, ability to take decisions, and capacity to manage the Service as it should. This had resulted also in considerable duplication of effort between the Department and Regions, with consequent duplications of staff and hence, of cost" (DHSS, 172, p. 75). De reorganisatie heeft de samenwerking met de onder de lokale overheid vallende maatschappelijke dienstverlening nog niet veel verbeterd, zo bleek uit de interviews. Deze samenwerking is vooral van belang voor de gezondheidszorg en maatschappelijke dienstverlening in de wijken en voor de afstemming van de bouw van bejaarden-en verpleeghuizen van de lokale overheid enerzijds en de intramurale instellingen van de NHS anderzijds. Voor dit gebrek aan samenwerking worden verschillende oorzaken genoemd. De NHS en de lokale overheid werden beide gelijktijdig gereorganiseerd. Het op orde stellen van de eigen organisatie eist zoveel aandacht, dat de samenwerking op het tweede plan komt. Ten tweede vallen de grenzen van de (sub)regio's van de Departments of social Services van de plaatselijke overheid niet samen met die van de health areas en health districts. Ten derde is er op de uitgaven van de County Councils en de maatschappelijke dienstverlening in het bijzonder meer besnoeid dan op gezondheidszorg. Gezamenlijke nieuwbouw van diensten-en gezondheidscentra kwam hierdoor op de tocht te staan. Als andere oorzaken werden verder genoemd het ontbreken van planningsgegevens over de eerstelijn, het zelfstandig blijven van de Family Practitioners Committees, en het om de vier jaar herkozen worden van de County Councils en de daaruit voortvloeiende andere werkwijze dan van de NHS. Door een vorm van joint financing probeert het DHSS de samenwerking te stimuleren. De financiële midde- 
len uit deze joint financing mogen hierbij alleen gebruikt worden voor gezamenlijke projekten (Brunel institute, 134, Ball, 125).

Een regelmatig genoemd probleem betreft de relatie tussen unit en sector administrators enerzijds en de functional officers anderzijds. Gewezen wordt op het verdwijnen van de Boards of Governors, die de unit administrators van het individuele academische ziekenhuis vormden, en rechtstreeks kontakten met het DHSS hadden. Gesignaleerd wordt ook een gebrek aan leiding in grote ziekenhuizen die vroeger onder één HMC vielen. De opsplitsing van een ziekenhuis in funktie met evenzovele funktionele budgethouders leidt verder tot een identificatieverlies bij medewerkers met het eigen ziekenhuis en gebrek aan coördinatie tussen de funkties binnen een ziekenhuis, zo wordt gesteld door de vertegenwoordigers van de landelijke vereniging van unit en sector administrators (Ball, 126, Chester, 143, Royal Commission on the NHS, 230, p. 185).

Ten gevolge van de hierboven genoemde knelpunten werd eind 1975 door de regering de Royal Commission on the NHS (231) ingesteld. Deze Royal Commission moet aanbevelingen doen over de onderfinanciering en de organisatorische knelpunten (Michael Ryan, 234). Uit gesprekken met een lid en met medewerkers van deze Royal Commission werd vernomen, dat in december 1977 reeds circa 3000 Evidences ontvangen waren uit brede kring van belangenorganisaties, gezondheidszorginstanties, en individuele personen. Deze Evidences worden door de medewerkers van de Royal Commission per aspekt samengevat en door de leden ervan daarna besproken. In een samenvatting in the Health and Social Services Journal in februari 1978 van de Evidences van de belangrijkste organisaties, blijken bovengenoemde knelpunten onderstreept te worden. De landelijke organisatie van Chief Administrators pleit voor een geleidelijke bijstelling van de struktuur (Ball, 125). Het Institute of Health Service Administrators (195) en de vereniging van leidinggevende verpleegkundigen pleiten voor integratie van de Family Practitioners in de NHS (Ball, 125). De British Medical Association pleit behalve voor private beds en een grotere professionele autonomie voor een integratie van de maatschappelijke dienstverlening en de gezondheidszorg (BMA, 129, Royal College of General Practitioners, 228). Ditzelfde doet ook de vereniging van direkteuren van afdelingen van maatschappelijke dienstverlening van de lokale overheden (Ball, 125).

Gevraagd naar hun mening over de Royal Commission bleken verschillende geinterviewde personen sceptisch te zijn. Het instellen van een Royal Commission werd door sommigen ervaren als een in de ijskast stoppen van de problemen. Verwacht werden als aanbevelingen een geleidelijke, plaatselijk aangepaste bijstelling van de nieuwe organisatiestruktuur in plaats van een nieuwe reorganisatie. Bij het ter perse gaan van dit boek bracht de Royal Commission haar eindrapport uit (233), waarin hiervoor gepleit wordt.

\subsubsection{Vergroten van betrokkenheid van patiënten en medewerkers}

\subsubsection{Satisfactie van medewerkers en patiënten}

In de afgelopen jaren is de arbeidsvreugde van NHS medewerkers vooral beinvloed door het reorganisatieproces, door de algemene politieke en economische situatie en ten derde door de kwestie van de particuliere bedden. Hieronder wordt elk van deze faktoren belicht.

\section{Het reorganisatieproces}

De invoeringsstrategie van de nieuwe struktuur was van voortschrijvende aard. Nadat in 1972 de NHS Reorganization Act was aangenomen met daarin de nieuwe 
struktuur, vulde het DHSS deze verder in met circulaires, verordeningen en informatiebulletins.

De belangen van het personeel hadden bij deze invulling de grootste prioriteit: zeer gunstige afvloeiingsregelingen voor ouder personeel, goede promotiekansen voor jonger personeel, het koppelen van een management funktie aan een professionele discipline. De voorbereiding van plaatselijke veranderingsplannen gebeurde door commissies, samengesteld uit betrokkenen van de oude NHS-organen.

Een uitgebreid scholingsprogramma werd opgezet door het DHSS voor de topleiding van iedere professie. In universiteiten werden kursussen georganiseerd van twee à vier weken. De RHB's organiseerden de bijscholing van het middenkader binnen hun regio's. De scholing betrof vooral informatieverschaffing over de nieuwe strukturen. Emotionele problemen van de mensen ten gevolge van de verandering kwamen nauwelijks aan de orde (Zie voor uitvoerige beschrijving van de invoeringsstrategie: Chester, 145, Edward, 182).

Deze strategie heeft onrust en verwarring (low morale) bij de werkers in de NHS niet kunnen voorkomen. Alle geïnterviewde personen, werkzaam binnen een gezondheidszorginstantie klaagden over de chaotische en onzekere maanden na 1 april 1974. Oude collega's waren vertrokken en nieuwe ervoor in de plaats gekomen. Vele vertrouwde en informele relaties waren teloor gegaan. Vooral dit laatste werd door vele geinterviewden benadrukt. Prof. T. Chester uit Manchester spreekt in april 1975 over de "traumatic experiences inflicted on thousands of health service workers" (Chester, 144). Het Institute for Health Studies in Hull zegt, na 15 maanden de reorganisatie in de Humberside AHA gevolgd te hebben, dat er een daling was in de arbeidsvreugde (morale) bij die groepen, die er persoonlijk het meest mee te maken hadden (Brown, 132). Anson, direktteur personeelszaken van de Trent RHA, constateert dat in $197530 \%$ van de senior administrators van de NHS jonger is dan 35 jaar, terwijl $48 \%$ een voor hun funktie onvoldoende opleiding hadden gevolgd (Anson, 124). Ook op politiek niveau worden de onzekerheden ten gevolge van de reorganisatie geconstateerd. David Owen, Parliamentary undersecretary of State for Health, stelt in juli 1974: "The government is acutely aware of the uncertainties and stresses which staff in the national health service are inevitably facing at the present time..." (Owen, 217, zie ook Falling standards and sagging moral, 187).

\section{De algemene politieke en economische situatie}

Dat de reorganisatie van de NHS gepaard ging met veel spanningen bij de medewerkers ligt niet alleen bij de gekozen invoeringsstrategie. De algemene politieke situatie was per 1 april 1974 uiterst ongunstig. De NHS Reorganization Act was afkomstig van een conservatieve regering, die van 1970 tot enige weken voor 1 april 1974 aan het bewind was. De Labour Party, die daarna aan de regering kwam had deze struktuur steeds gekritiseerd vanwege het ontbreken van een rechtstreekse vertegenwoordiging van consumenten en personeel in de gezondheidsautoriteiten. Het eerste dat de nieuwe Labour-regering dan ook deed, was het uitbreiden van de area en regional authorities met vertegenwoordigers van personeel en lokale overheid. Hoewel op zich geen fundamentele wijzigingen in de struktuur, leverden deze toch onzekerheden op over het toekomstige beleid. De regeringswisseling had meer gevolgen. Het nieuwe planningsysteem zou begin 1974 uitkomen, maar de Labour-regering wilde het nog eens onderzoeken en bracht pas in 1975 een concept-en in juni 1976 een definitieve regeling uit. Het wantrouwen in het DHSS ten gevolge van het niet nakomen van deze toezegging nam hierdoor toe. Immers de nieuwe geintegreerde planning is een van de meest essentiële kenmerken van de nieuwe struktuur (zie par. 3.3.1.). De regering die in februari 1974 aan het bewind kwam, was bovendien 
een minderheidsregering, die impopulaire maatregelen uitstelde en de voorkeur gaf aan stemmentrekkende besluiten. Zo werden de besnoeiingen ten gevolge van de economische crisis op de kapitaal-uitgaven van de NHS uitgesteld en een gratis familyplanning-program versneld ingevoerd. Deze politiek vergrootte niet bepaald de rust bij de NHS-medewerkers.

De zich verslechterende economische situatie in 1974 belemmerde evenzeer een goede start van de reorganisatie. De nieuwe struktuur was eind zestiger, begin zeventiger jaren ontworpen en ging uit van een groeiende economie. Verwacht werd, dat de reorganisatie de wijkgezondheidszorg en de zorg voor chronische patiënten zou stimuleren. Doordat de economische recessie in Engeland samenviel met de start van de reorganisatie bleek echter het probleem van de onderfinanciering hetzelfde te blijven. Het Institute of Hull zegt in een verslag over de reorganisatie van de NHS in een bepaalde AHA dan ook: "New Bottles, Old Wine?" (Brown, 132). De slechte economische situatie leidde in 1974 tot vele akties van de verschillende groepen van werkers. In de tweede helft van 1974 werd de patiëntenzorg constant onderbroken door akties voor betere arbeidsvoorwaarden van verpleegkundigen, röntgenologen, technici, onderhoudspersoneel en ambulance-rijders. Artsen weigerden zitting te nemen in commissies van december 1974 tot april 1975 (Brown, 132). In latere jaren bleven deze akties voor betere arbeidsvoorwaarden in een stagnerende economie zich voortzetten.

\section{Particuliere bedden}

In 1975 nam het parlement een wet aan om de particuliere bedden in NHS-ziekenhuizen te verminderen van circa 4000 naar 2000 met als gevolg een verdere organisatorische inpassing en een inkomstenvermindering voor (een deel van de) medische professie.

Hoewel deze verandering voor de gehele NHS van slechts geringe betekenis was 4000 bedden is circa $1 \%$ van het totaal aantal -, was het verzet van de medische professie groot en zette deze nieuwe wet veel kwaad bloed (zie Crisis of Confidence in NHS, 155, Ball, 127 en NHS-Private beds, 211).

Uit de interviews kwam de low morale van de medewerkers ten gevolge van de drie hierbovengenoemde faktoren wat gematigder naar voren dan in de vakpers van de diverse beroepsgroepen. Er werd op gewezen, dat vlak na de reorganisatie verschillende beroepsgroepen de kans grepen hun financiële en organisatorische positie te versterken. Juist de onduidelijke maanden na de reorganisatie, waarin de machtsverhoudingen niet duidelijk waren, waren hiervoor geschikt. Ook werd de aandacht gevestigd op het feit, dat de organisatiestruktuur in de NHS optimale kansen biedt voor de inspraak van de verschillende beroepsgroepen via hun vertegenwoordiging in de management teams.

Het verzet van de artsen tegen de reorganisatie op zich is - zo werd in verschillende interviews duidelijk gemaakt - gering geweest. Ze waren zelf de eersten om voor eenheid van bestuur te pleiten. Via de Cogwheel Reports $(D H S S, 163)$ was hun advisory machinery reeds tot stand gekomen, die de invloed van de medische professie veilig stelde. In feite had de reorganisatie van de NHS weinig invloed op de individuele arts. Het betaal-systeem bleef ongewijzigd op de particuliere bedden na. Ook de Family Practitioners bleven autonoom via hun Family Practitioners Committee. De inkomenspolitiek ten opzichte van artsen had ook invloed op de low morale, zo werd in de interviews duidelijk gemaakt. Dat dit aannemelijk is, blijkt uit het volgende. In 1965 verdiende een gemiddelde specialist consultant on the seventh point bruto per jaar $£ 4100$ en na belastingaftrek $£ 3058$. Met behoud van koopkracht zou dit inkomen in $1976 £ 13.012$ moeten bedragen. Het gemiddeld inkomen in dat 
laatste jaar bedroeg echter $£ 9900$ (Newbould, 212).

De patiënten lijken weinig te hebben gemerkt van de reorganisatie. Eskin en Newton (183) interviewden op twee werkdagen in 1977 honderd personen in het centrum van Manchester. De groep bestond uit evenveel mannen als vrouwen. De jongere leeftijdsgroepen en de hogere sociale klassen waren enigszins oververtegenwoordigd. Van deze honderd personen wist tien procent dat er een reorganisatie van de NHS had plaatsgevonden. Hieraan herinnerd wist $13 \%$ de juiste datum ervan te noemen. De geinterviewden bleken een betere kennis van de startdatum van de NHS te hebben: $45 \%$ noemde 1946, 1947 of 1948 . Gevraagd naar de naam van de AHA, waaronder men ressorteerde, wist $42 \%$ een juist antwoord te geven. Van het bestaan van de CHC's wist $13 \%$ af. Op de vraag, wat naar hun mening het grootste probleem van de NHS tegenwoordig is, antwoordde 55\% met "lack of money". Van de steekproef vond tenslotte 78\% de NHS "very good", "good" of "adequate". Voor $11 \%$ gold "not so good" en voor de resterende $11 \%$ "inadequate" of "awful".

\subsubsection{Inspraak van medewerkers en patiënten}

Voorafgaande aan belangrijke besluiten moeten de gezondheidsautoriteiten vele belangengroepen horen, zoals lokale overheden, professionele organisaties, vakbonden en patiëntengroeperingen. Gekozen is hierbij voor een gescheiden advisering, zodat de eigen mening van elke groepering rechtstreeks bij de management teams terecht kan komen. De reakties, die in de inspraakrondes naar voren komen, worden eerst van duplieken voorzien door de management teams, voordat uiteindelijk een besluit genomen wordt. In interviews met verschillende NHS-medewerkers kwam onvrede naar voren met deze gang van zaken. Onduidelijk was op welk niveau de beslissingen nu eigenlijk genomen werden. Zowel vertegenwoordigers van de managementprofessie als van de medische professie klaagden over de sinds de reorganisatie toegenomen consultatierondes (zie ook: Ball, 125, Institute of Health Services Administrators, 195, British Medical Association, 129). Als een van de oorzaken van het opzetten van de uitgebreide overlegprocedures is te noemen het feit dat de oorspronkelijke voorstellen voor de NHS-reorganisaties politiek werden ingekleurd. Protesten van verschillende belangengroepen werden hierbij afgekocht met een zekere inspraak (zie ook Klein, 202).

Als specifiek inspraakorgaan voor patiënten is per 1 april 1974 de Community Health Council (CHC) ingesteld (zie par, 3.2.).

De CHC bestaat uit 18 à 30 leden, waarvan minstens de helft door de lokale overheid en minstens éénderde door de RHA is benoemd. Per advertentie worden belangenorganisaties van patiënten op de hoogte gebracht van de mogelijkheid een vertegenwoordiger aan te wijzen. Meestal zijn de door de RHA gekozen leden voormalige medewerkers van de NHS, vertegenwoordigers van vakbonden, kerken of vrijwilligersorganisaties.

De CHC geeft zijn kommentaar in alle inspraakrondes die voorafgaan aan belangrijke besluiten. Een belangrijke bevoegdheid van de $\mathrm{CHC}$ is, dat zij de betreffende DMT en AHA om inlichtingen en uitleg mag vragen over bepaalde gebeurtenissen. Het DMT en de AHA zijn verplicht antwoord te geven op dergelijke verzoeken. Jack Hallas (193) beschrijft in zijn boek "CHC's in Action" de ervaringen met CHC's gedurende de eerste anderhalf jaar van hun bestaan. Zij lijken zich met hun vragen te richten op de RHA en het DHSS. Voor een deel komen deze kontakten voort uit het idee, dat via deze omweg de wensen van de CHC voor de district- en AHA-plannen beter tot hun recht kunnen komen. In de bezochte districten werden de CHC's gezien als een lastig orgaan, dat buiten de NHS geplaatst is. Verder bleken er competentiekwesties te spelen tussen de AHA's en de CHC's. 


$$
\text { - }
$$




\section{REGIONALISATIE EN FINANCIERING VAN DE ZWEEDSE GEZONDHEIDSZORG}

\subsection{ALGEMENE KENMERKEN VAN ZWEDEN}

\subsubsection{Demografische en macro-economische kenmerken}

In tabel 4.1.1. worden enkele gegevens vermeld over de demografische en macro-economische opbouw van Zweden. Van 1950 tot 1975 groeide de bevolking van 7 naar 8,2 miljoen. Verwacht wordt, dat de omvang in 1990 circa 8,7 miljoen zal bedragen. De Zweedse bevolking vergrijst: in 1950 was $10,2 \%$ van de bevolking ouder dan 65 jaar. In 1975 bedroeg dat percentage 14,6\%. In 1990 wordt een percentage van $16,5 \%$ verwacht. Deze veroudering hangt samen met een dalend geboortecijfer. In 1950 werden per 1000 inwoners 16,5 kinderen geboren. In 1975 was dit aantal 13,5. Voor 1990 wordt een geboortecijfer verwacht, dat hieraan gelijk is. De bevolkingsdichtheid stijgt van 17 inwoners per $\mathrm{km}^{2}$ in 1950 naar 20 in 1975 en naar verwachting 21 in 1991. Zweden kent een parlementaire democratie met vrije ondernemingsgewijze produktie, die globaal door de rijksoverheid wordt geordend. De beroepsbevolking bestaat uit $4 \mathrm{mln}$. arbeidskrachten. Hiervan werkt $6,7 \%$ in de landbouw en de visserij en $37,0 \%$ in de industrie. Meer dan de helft van de beroepsbevolking $(56,3 \%)$ werkt in de overige sektoren, voornamelijk bestaande uit dienstverlenende sektoren. Het Bruto Nationaal Produkt (BNP) tegen marktprijzen van Zweden bedroeg in 1975286,7 mld. kronen. In 1975 is het BNP bijna tienmaal zo hoog als in 1950. Gemeten in prijzen van 1970 bedraagt het BNP in 195048 , in 1970100 en in 1975112.

Zweden maakt thans de zwaarste na-oorlogse economische recessie mee. Van 1963 tot en met 1974 bedraagt de reële groei van het BNP gemiddeld 3,6\%. Voor de jaren na 1973 bedraagt deze groei (Ministry of Economic Affairs, 285, p. 8):
$1974 \quad 4,0 \%$
$1975 \quad 0,9 \%$
$1976 \quad 1,7 \%$
$1977-2,4 \%$
$1978 \quad 0,2 \%$

Vanaf 1976 is er geen reële groei van de bestedingen van de rijksoverheid. De bruto investeringen, gemeten in constante prijzen dalen sinds 1975. Ditzelfde geldt sinds 1977 voor de particuliere consumptie en de totale binnenlandse vraag. Het prijsindexcijfer voor de gezinsconsumptie was in 1975 bijna 3,5 maal zo hoog als in 1950 (zie tabel 4.1.1.). Dit komt neer op een inflatie van vijf procent gemiddeld per jaar. Vanaf 1971 bedraagt de jaarlijkse inflatie (SOS, 309):
1971
$7,6 \%$
1975
$9,8 \%$
1972
$5,9 \%$
1976
$10,1 \%$
1973
$6,7 \%$
1977
$11,5 \%$

$1974 \quad 10,1 \%$

Om de uitvoer te stimuleren en de invoer af te remmen is de Zweedse kroon in de afgelopen jaren regelmatig gedevalueerd. De wisselkoers uitgedrukt in guldens per 100 


\begin{tabular}{|c|c|c|c|}
\hline & 1950 & 1975 & $\begin{array}{l}\text { Verwachting } \\
1990\end{array}$ \\
\hline $\begin{array}{l}\text { Bevolkingsomvang in mln. } \\
\text { - waarvan } 65 \text { jaar en ouder } \\
\text { Aantal levend geborenen per } 1000 \text { inwoners } \\
\text { Bevolkingsdichtheid (aantal inwoners per } \\
\mathrm{km}^{2} \text { ) } \\
\text { Beroepsbevolking in mln. arbeidskrachten } \\
\text { waarvan landbouw, visserij en mijn bouw } \\
\quad \text { industrie } \\
\quad \text { overige sektoren } \\
\text { Bruto Nationaal Produkt tegen marktprijzen } \\
\text { in mld. Zweedse Kronen (BNP) } \\
\text { BNP } 1970=100 \\
\text { BNP, tegen constante prijzen ( } 1970=100) \\
\text { Prijsindexcijfer van de gezinsconsumptie } \\
(1970=100)\end{array}$ & $\begin{array}{l}7,0 \\
10,2 \% \\
16,5 \\
17\end{array}$ & $\begin{array}{l}8,2 \\
14,6 \% \\
13,5 \\
20 \\
4 \\
6,7 \% 1 \\
37,0 \% 1 \\
56,3 \% \\
286,7 \\
168 \\
112 \\
147\end{array}$ & $\begin{array}{l}8,7 \\
16,5 \% \\
13,6 \\
21\end{array}$ \\
\hline
\end{tabular}

Bron: OECD (292), SOS (308 en 309).

11974.

SK bedraagt vanaf $1970(C B S, 22)$ :
197069,73
197460,58
$1971 \quad 68,43$
197560,95
$1972-67,51$
$1976 \quad 60,17$
197363,40
197750,30

De Zweden onderkenden aanvankelijk niet, dat de energiecrisis en de daarop volgende recessie symptomen waren van struktureel scheefgegroeide verhoudingen. Ze rekenden erop, dat de terugslag van korte duur zou zijn. Daardoor maakten zij de fout hun ondernemers door subsidies ertoe aan te moedigen op voorraad te produceren. Hierdoor bleef de werkloosheid in 1975 en 1976 relatief laag, maar stegen de voorraden enorm (Nelissen, 289 en Ministry of Economic Affairs, 283 en 285). Op grond hiervan en de economische groei in de OECD-landen is voor de periode na 1978 voor Zweden een geringere reële groei te verwachten van het BNP dan in de jaren zestig (Ministry of the Budget, 284).

\subsubsection{Gezondheidstoestand van de bevolking}

In tabel 4.1.2. worden enige kriteria aangegeven voor de somatische gezondheidstoestand van de Zweedse bevolking. De gemiddelde verwachte levensduur van mannen stijgt over de periode 1950-1975 met drie jaren, van 69,0 naar 72,1 jaar. Voor vrouwen is deze stijging zes jaar, van 71,6 naar 77,7 jaar. De perinatale sterfte en de sterfte aan infektieziekten dalen beide aanzienlijk over de onderzochte periode. De totale mortaliteit stijgt van 963 naar 1081 sterfgevallen per 100.000 inwoners.

Het mortaliteitspatroon is in 1975 anders dan dat in 1950. Sterfte aan kwaadaardige nieuwvorming en aan hart- en vaatziekten zijn in beide jaren de belangrijkste doodsoorzaken. In 1950 wordt $53 \%$ van de sterfgevallen door beide veroorzaakt. In 1975 bedraagt dat percentage echter $76 \%$. Andere kriteria voor de gezondheidstoe- 
Tabel 4.1.2. Gezondheidstoestand van de bevolking in $Z$ weden

\begin{tabular}{lcc}
\hline Gemiddelde verwachte levensduur & 1950 & 1975 \\
\hline - mannen & $\left.69,0^{1}\right)$ & $\left.72,1^{2}\right)$ \\
- vrouwen & $\left.71,6^{1}\right)$ & $\left.77,7^{2}\right)$ \\
Perinatale sterfte per 1000 geborenen & 32,3 & 13,3 \\
Mortaliteit per 100.000 inwoners & & \\
Alle doodsoorzaken & $\left.963^{3}\right)$ & 1081 \\
infektieziekten & $\left.21^{3}\right)$ & 8 \\
kwaadaardige nieuwvormingen & $\left.169^{3}\right)$ & 241 \\
hart- en vaatziekten & $\left.337^{3}\right)$ & 577 \\
overige ziekten & $\left.440^{3}\right)$ & 243 \\
\hline
\end{tabular}

Voetnoot: ${ }^{1} 1946-1950,{ }^{2} 1971-1975,{ }^{3} 1951-1955$

Bron: SOS (309), United Nations Organization (240).

stand van de bevolking, de zorgbehoeften en kriteria voor het geestelijk welbevinden, zijn uit statistische bronnen niet te verkrijgen. Uit beleidsstukken van de overheid en nationale instanties komt een stijgende behoefte aan chronische patiënt-verzorging naar voren in verband met de veroudering van de bevolking. In interviews van het onderzoek in de verschillende landstingen wordt deze behoefte eveneens gesignaleerd (zie Socialstyrelsen, 296 en Socialdepartementet, 295). Over de geestelijke gezondheidstoestand van de Zweedse bevolking is weinig te zeggen. In gesprekken in Nederland werd gewezen op het alcoholisme en het hoge aantal zelfmoorden onder de bevolking, die beide zouden wijzen op een slecht geestelijk welzijn vergeleken met andere Europese landen.

Het alcoholisme zowel gemeten in aantal alcoholici per 100.000 inwoners als in alcoholconsumptie per inwoner, is te vergelijken met Engeland en Nederland en aanmerkelijk lager dan in Frankrijk of Italië (Löfgren, 280).

Het aantal suiciden bedroeg in 1975 in Zweden 20 per 100.000 inwoners (SOS, 277). Dit is hoger dan in het Verenigd Koninkrijk en Nederland, waar in 1975 dit aantal acht bedroeg (DHSS, 164 en $C B S, 22)$. Niet gesteld kan worden dat de recente maatschappelijke ontwikkelingen in Zweden dit verschil hebben veroorzaakt, aangezien in 1950 ook reeds verschillen bestonden (Zweden: 17, Verenigd Koninkrijk: 10 en Nederland: 6 zelfmoorden per 100.000 inwoners). Eerder lijkt een relatie te leggen met een geringe schroom in Zweden om zelfmoorden te melden.

\subsubsection{Organisatie van het overheidsbestel}

Op nationaal niveau wijkt het $Z$ weedse overheidsbestel af van dat in Nederland. Het kenmerkende verschil is, dat de beleidsformulering en de beleidsuitvoering gescheiden zijn. De beleidsformulering vindt plaats bij de regering en het parlement, dat slechts één kamer met 349 zetels heeft. De relatie tussen regering en parlement is te vergelijken met die in Nederland (zie uitgebreid Navarro, 288). De ministeries zijn een soort staforgaan van het kabinet en houden zich voornamelijk bezig met voorbereiding en uitwerking van wettelijke kaders, het onderhouden van kontakten met het parlement en benoemingen in hoge funkties van de nationale raden. Het kabinet als gehee $\Gamma$ is verantwoordelijk voor regeringsbesluiten.

Belangrijke wetten worden vaak voorbereid door Krooncommissies, die te vergelijken zijn met de Royal Commissions in het Verenigd Koninkrijk (zie par. 3.2.). De uitwerking en uitvoering van het overheidsbeleid vindt plaats via Styrelsen (nationale raden), die formeel zelfstandig ziin en op een bepaald terrein werkzaam. 
Deze uitvoeringsorganen zijn veel groter dan de ministeries. Het personeelsbestand bij het Ministerie van Volksgezondheid en Sociale Zaken is ongeveer 100. Bij de Socialstyrelsen (Nationale Raad voor Gezondheid en Welzijn), bedraagt het aantal personeelsleden ongeveer 3000 . De nationale raden zijn verantwoording verschuldigd aan het kabinet. Zij kunnen rechtstreeks voorstellen doen aan het kabinet met betrekking tot het te voeren beleid. Ook kunnen zij amendementen voorstellen op wetsontwerpen, die bij het kabinet en het parlement in behandeling zijn. Het Ministerie van Volksgezondheid en Sociale Zaken houdt zich vooral bezig met de voorbereiding van de wetgeving voor de gezondheidszorg en sociale verzekeringen. De belangrijkste nationale raden van het ministerie zijn de reeds genoemde Socialstyrelsen en de Forsäkrungstyrelsen, de Nationale Raad voor de Sociale Verzekeringen. De voornaamste taken van de Socialstyrelsen bestaan uit:

- de zorg voor de volksgezondheid, de geneesmiddelenvoorziening en het maatschappelijk welzijn.

- Te plamming op nationaal niveau van deze drie aktiviteiten, en bovendien het ondersteunen en op elkaar afstemmen van de lokale en regionale plannen.

- het toezicht op de uitvoering van de gezondheidszorg.

De verhouding tussen ministerie en Socialstyrelsen, zo bleek uit een aantal gesprekken met funktionarissen van beide, is ambivalent, omdat enerzijds de laatstgenoemde onafhankelijk is met betrekking tot de uitvoering van het beleid en anderzijds wel afhankelijk van het ministerie met betrekking tot de financiële middelen voor de beleidsuitvoering.

Op het ogenblik zijn er in Zweden 23 landstingen (provincies) en 3 vergelijkbare openbare lichamen, Malmö, Götenborg en het eiland Gotland (zie grafiek 1.3.2.2.). De landstingen variëren aanzienlijk in inwonertal en oppervlakte van hun bestuurlijk gebied - län - : van 125.000 inwoners tot 1,5 miljoen inwoners; van een län met een oppervlakte van $98.000 \mathrm{~km}^{2}$ tot een met een oppervlakte van nog geen 3000 $\mathrm{km}^{2}$. Door de inwoners van iedere län wordt de landsting gekozen voor een periode van 3 jaar. Deze verkiezingen vinden gelijktijdig met die voor het parlement en de gemeenteraden plaats. Het aantal leden van de landsting hangt af van het aantal inwoners in de län; 33 in de län met het minste aantal inwoners, 149 leden in de län met de meeste bewoners. De leden kiezen uit hun midden een dagelijks bestuur, te vergelijken met de Colleges van Gedeputeerde Staten van de Nederlandse Provincies. De leden hiervan hebben thans een volledige dagtaak en beheren elk een eigen portefeuille. De voorbereiding en uitvoering van de door dit dagelijks bestuur vastgestelde besluiten ligt in handen van ambtelijke medewerkers van de landsting. De landstingen zijn verenigd in een overkoepelende belangenorganisatie, de landstingförbundet (272). Reeds meer dan een eeuw is de belangrijkste taak en verantwoordelijkheid van de landstingen de zorg voor de volksgezondheid.

Naast de landstingen bestaan de gemeenten. De voornaamste taken van deze zijn:

- volkshuisvesting en woningbouw, ruimtelijke ordening en aanleg en onderhoud wegen

- zorg voor kulturele en rekreatieve voorzieningen en milieuhygiëne

- onderwijs en opvang van kinderen in dagverblijven (70\% van de gehuwde vrouwen werkt)

maatschappelijke dienstverlening: algemeen maatschappelijk werk, huisvesting van bejaarden in bejaardenoorden, open bejaardenwerk, extramurale zorg voor gehandicapten.

Zweden wordt gekenmerkt door een grote trek naar de steden. In de drie grootste steden woont $30 \%$ van de bevolking; $90 \%$ woont in de zuidelijke helft van het land. Om uitholling van de gemeentelijke taken te voorkomen werd in de jaren zestig gekozen voor 
schaalvergroting, waardoor het aantal gemeenten tot minder dan 300 afnam.

\subsection{ORGANISATIESTRUKTUUR VAN DE GEZONDHEIDSZORG}

Kenmerkend voor de tegenwoordige struktuur van de Zweedse gezondheidszorg zijn ten eerste de echelonnering en ten tweede de regionalisatie.

In de Zweedse gezondheidszorg worden drie zorgniveau's of echelons onderscheiden. In de open zorg zijn de districtsartsen, districtsverpleegkundigen en districtsvroedvrouwen werkzaam in districts-artsenposten (läkarstation) en in gezondheidscentra (vardcentral), en ziekenhuisklinieken.

De districtsartsen verrichten aktiviteiten, die in Nederland in huisartsenpraktijken en ziekenhuispoliklinieken worden verricht. De districtsverpleegkundige is te vergelijken met de Nederlandse wijkverpleegkundige.

Grafiek 4.2.1. geeft de geografische opbouw van deze open gezondheidszorg aan binnen een landsting. Een rol in de open zorg spelen de particuliere artsen. In Zweden werken 17.000 artsen, waarvan 800 full-time een particuliere praktijk hebben. Van deze laatsten is eenderde huisarts en tweederde specialist (Nicolausson, 291). Een ander 800-tal artsen heeft een part-time particuliere praktijk (Mosten, 287). Al deze artsen werken buiten de ziekenhuizen. De particuliere artsen bevinden zich vooral in de grote steden. Zo hebben Stockholm en Malmö één particuliere arts op 2500 resp. 3300 inwoners. In de noordelijke landstingen is deze verhouding $1 \mathrm{op}$ 33.000 (Norrbotten) en 1 op 25.000 (Västerbotten). De particuliere artsen namen in $197519 \%$ van de niet-klinische consulten voor hun rekening (Mosten, 287).

Als de technische hulpmiddelen in het eerste echelon ontoereikend zijn, dan komt het middelste echelon (länssjukvård) in aanmerking. Dit is het niveau van de ziekenhuiszorg, waar de verantwoordelijkheid ligt voor de patiënten in levensbedreigende toestand en voor patiënten met ziekten die toegang tot meer gespecialiseerd personeel en technische hulpmiddelen vereisen. Binnen dit tweede echelon worden twee type ziekenhuizen onderscheiden, namelijk districts- (of basis-) ziekenhuizen (länsdelssjukhus, vroeger alis normalsjukhus of normallasarett aangeduid) en provinciale (of centrale-) ziekenhuizen (länssjukhus, vroeger aangeduid als centrallasarett). Tussen deze beide soorten van ziekenhuizen is geen kwalitatief, doch wel een kwantitatief verschil aanwezig. De werkzaamheden in het basisziekenhuis zijn in principe van hetzelfde karakter en van dezelfde kwaliteit als de werkzaamheden in het centrale ziekenhuis. De differentiatie van de werkzaamheden in het basisziekenhuis is echter geringer doordat er sprake is van een minder breed samengesteld specialismenpakket dan in het centrale ziekenhuis wordt aangetroffen.

Voor het hoogste echelon (regionsjukvärd) tenslotte ligt de verantwoordelijkheid voor dat kleine aantal patiënten die moeilijk te diagnosticeren zijn of moeilijk te behandelen ziektes hebben. De medisch specialismen, waarvoor deze ziekenhuisregio's gelden, betreffen plastische chirurgie, thoraxchirurgie, neurochirurgie, radiotherapie, urologie, kinderchirurgie, dermatologie (gedeeltelijk), neurologie (gedeeltelijk), reumatologie (gedeeltelijk), cardiologie (gedeeltelijk) en nefrologie. Ten behoeve van patiënten voor deze specialismen zijn zeven in grafiek 4.2.2. aangegeven ziekenhuisregio's opgezet. De zorg in dit echelon wordt alleen verleend vanuit regioziekenhuizen, waar verder alle voorkomende specialismen aanwezig zijn (zie uitvoerig Dokter-De Leeuw, 261).

Grafiek 4.2.3. geeft een overzicht van de opbouw van de gezondheidszorg naar zorgniveau. Deze echelonnering is in de jaren zestig opgezet en uitgewerkt door A. Engel, direkteur-generaal van de Socialstyrelsen (Engel, 265). 


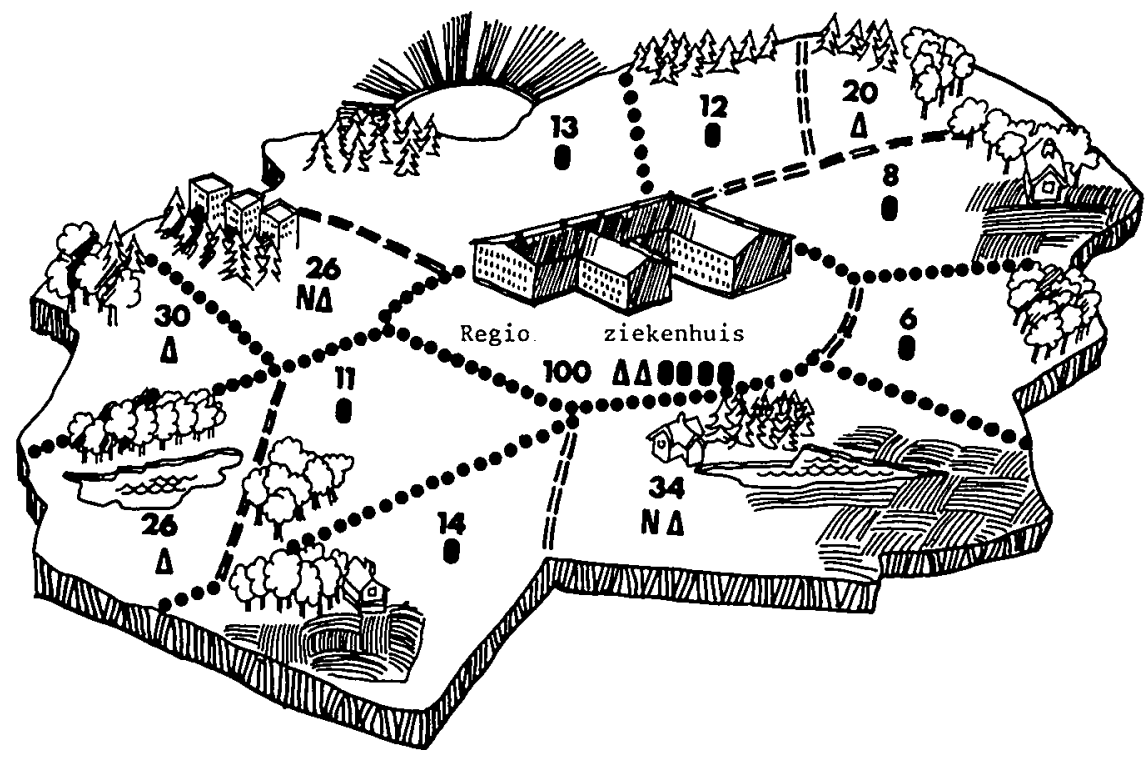

$\mathrm{N}=$ algemeen ziekenhuis

$\boldsymbol{\Lambda}=$ groot gezondheidscentrum

- klein gezondheidscentrum

.. = giens van de gemeente en van het verzorgingsgebied van de eerstelijnszorg

$== \pm$ gemeentegrens

34 = antal inwoners van de gemeente in 1000-tallen

Bron: SPRI (272) 


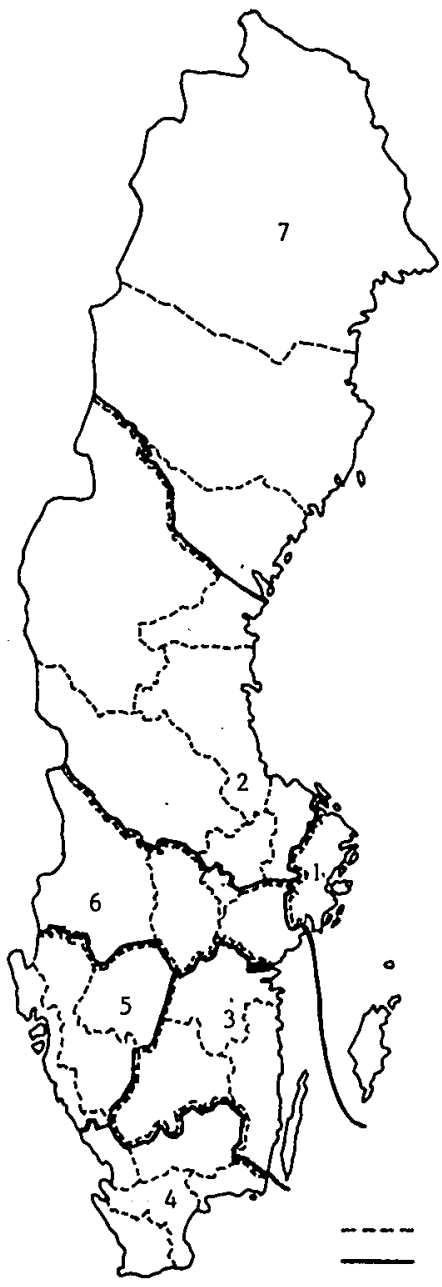

landstingsprens

grens ziekenhuisregio
Toelichting: Naam van de regio en aantal inwoners per 31-12-1974

1. Stockholmsregionen $\quad 1,5 \mathrm{mln}$

2. Uppsalaregionen $\quad 1,3 \mathrm{~min}$

3. Linköpingsregionen $\quad 0,9 \mathrm{mln}$

4. Lund-Malmöregionen $\quad 1,5 \mathrm{mln}$

5. Götenborgsregionen $\quad 1,5 \mathrm{mln}$

6. Örebroregionen $\quad 0,9 \mathrm{mln}$

7. Umearegionen $\quad 0,6 \mathrm{mln}$

Totaal

Bron: SOS (277) 
Grafiek 4.2.3. Opbouw van de Zweedse gezondheidszorg naar zorgniveau

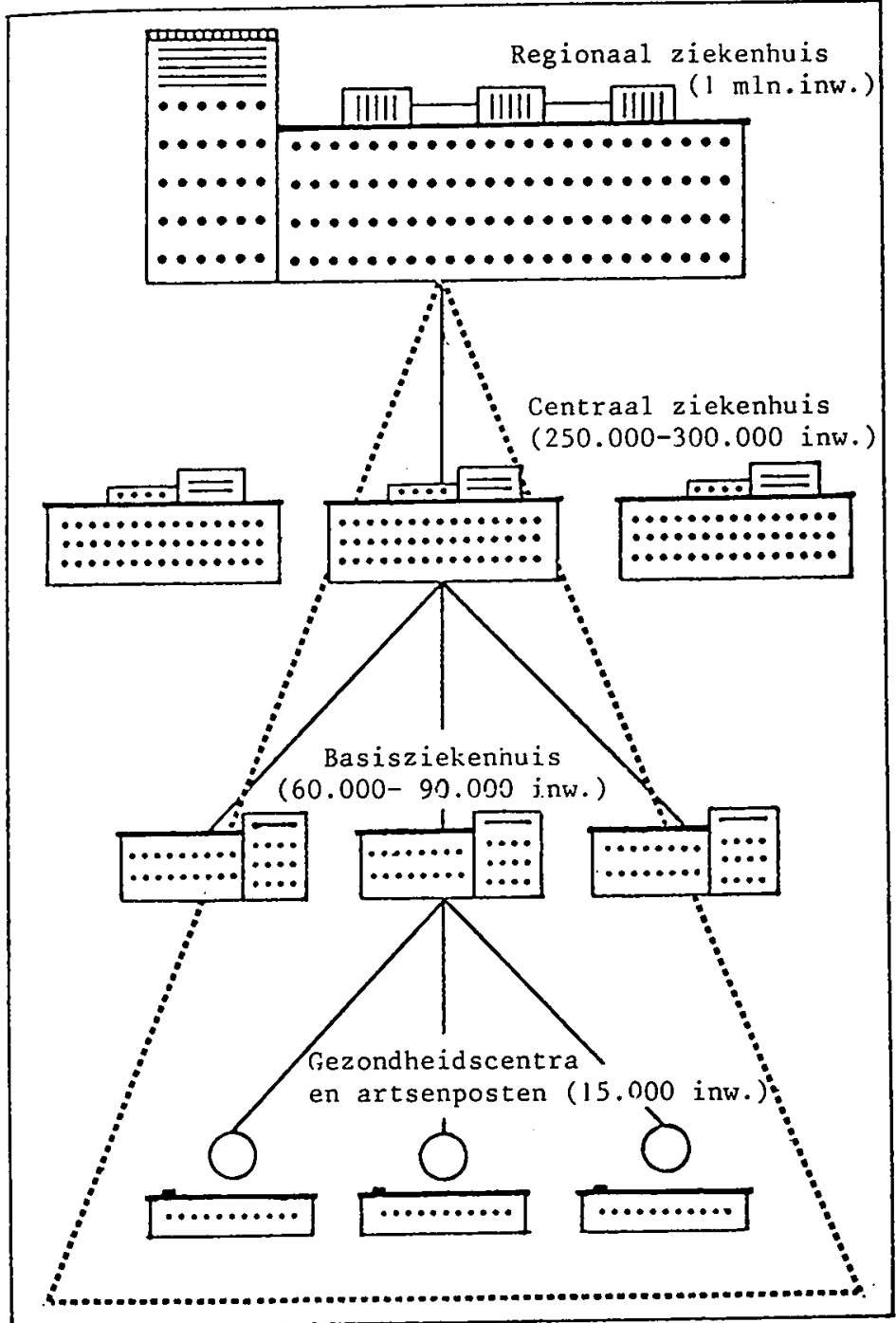

Bron: Navarro $(257$, p. 79$)$ 
Van oudsher is het Zweedse ziekenhuiswezen per landsting georganiseerd. Voor de overige gezondheidszorg was dit niet het geval. Deze viel onder de rijksoverheid (de extramurale gezondheidszorg) en onder de gemeenten (de zorg voor chronische zieken). In de periode $1950-1970$ is in de Zweedse gezondheidszorg geleidelijk een reeks van vernieuwingen ingevoerd, die ertoe hebben geleid dat op dit moment praktisch de gehele gezondheidszorg onder de verantwoordelijkheid valt van de landstingen. In 1951 werd de zorg voor chronisch zieken overgedragen van de gemeenten naar de landstingen. In 1963 volgde de overname door de landstingen van het stelsel van de extramuraal werkende distriktsartsen, dat tot dan onder de rijksoverheid viel. In 1967 namen de landstingen de verantwoordelijkheid van de rijksoverheid over voor de geestelijke gezondheidszorg. In 1970 volgde de zeven - kronen - hervorming. Bij deze hervorming werd bepaald, dat artsen voor hun klinische en poliklinische werkzaamheden een vast salaris ontvangen ongeacht het specialisme. Tot 1970 was dit reeds het geval voor de klinische werkzaamheden van de specialisten. De landstingen ontvangen vanaf dat jaar per eerste consult in de open zorg een bepaald tarief. Deze hervorming was gericht op het stimuleren van het poliklinische werken (Navarro, 288, p. 58). In 1971 werd de gezondheidszorg van de gemeente Stockholm ondergebracht onder de landsting Stockholm (Borgenhammer, 251, $\mathrm{p}$. 21.). Ten gevolge van bovenstaande veranderingen vallen nu $90 \%$ van de bedden van de intramurale voorzieningen en alle extramurale voorzieningen op de particuliere artsen na onder de verantwoordelijkheid van de landstingen. De resterende $10 \%$ van de bedden wordt gevormd door twee rijks Academische Ziekenhuizen en door particuliere verpleeghuizen $(S O S, 308)$.

Naast de indeling van de gezondheidszorg per landsting bestaan er ook indelingen naar grotere en kleinere regio's. Voor de medische topvoorzieningen bestaat de reeds genoemde indeling in zeven ziekenhuisregio's (zie grafiek 4.2.1.2.). De landstingen zijn vrij hun eigen subregio's te vormen. Een groeiend aantal landstingen gaat hiertoe over (mededeling landstingförbundet). Binnen veertien landstingen bestaan in 1977 geografische subregio's, genoemd districten. Deze subregio's bestaan in onder andere Stockholm, Malmöhus en Norrbotten. De leden van het algemene en dagelijkse landstingsbestuur (zie par. 4.1.3.) hebben zitting in commissies, die de verantwoordelijkheid hebben over dergelijke districten. Twee landstingen zonder districten (Skaraborg en Orebrö) kennen een organisatorische indeling naar zorgsoort. Onderscheiden worden bijvoorbeeld het chirurgische blok en het eerstelijnsblok. In Stockholm bestaat binnen de te onderscheiden districten een dergelijke blokkenstruktuur. Voor een uitvoerige beschrijving van de organisatorische opbouw van landstingen, zie Landstingförbundet (274) en Swedish Medical Association (276).

Het leggen van de verantwoordelijkheid voor de gezondheidszorg bij één orgaan - de landsting - wordt in verschillende Zweedse publikaties gezien als noodzakelijk voor de integratie van de gezondheidszorg. Hieronder komt een aantal van deze publikaties aan de orde.

In 1977 bracht het Zweedse ministerie voor sociale zorg een rapport uit over de Zweedse sociale politiek (Socialdepartementet, 295). Dit rapport werd opgesteld ten behoeve van een conferentie van de desbetreffende ministers van de verschillende Scandinavische landen. In het hoofdstuk over gezondheidszorg geeft het $Z$ weedse ministerie aan, dat het de reorganisatie in de jaren zestig ziet als een basis voor de integratie van de verschillende soorten zorg. Hieronder volgt de vertaling van de eerste regels van het genoemde hoofdstuk. "De medische ontwikkeling heeft ertoe geleid, dat het voor de individuele arts steeds moeilijker is geworden om deze ontwik- 
keling te volgen, anders dan op beperkte gebieden. Dit heeft geleid tot een vergaande specialisatie en centralisatie van de ziekenzorg. Dit is vanuit vele gezichtspunten positief geweest. Het heeft condities geschapen voor een omvangrijke medische research en een geavanceerde medische diagnostiek en behandeling.

De laatste jaren is het echter steeds duidelijker geworden dat een goed werkende eerstelijnszorg, die dichtbij is en kontinuiteit kan bieden, de grondslag van de organisatie van de ziekenzorg moet vormen. Een nauwere samenwerking tussen medische en sociale organen vooral in de eerstelijnszorg blijkt nu noodzakelijk. Gelijktijdig is steeds meer aandacht aan de behoefte van preventieve maatregelen geschonken. Een grotere belangstelling wordt nu besteed aan do-verschillende-vormen van gezondheidsvoorlichting en gezondheidscontroles. De ontwikkeling van het beleid in Zweden voor de gezondheidszorg in de laatste jaren wordt daarom gekenmerkt door een uitbreiding van de poliklinische gedecentraliseerde zorg, alsmede van de zorg bij langdurige opname, benevens gekenmerkt door een grotere belangstelling voor preventieve maatregelen. De basis van deze coördinatie op het gebied van de ziekenzorg werd in de jaren zestig gelegd toen voor de gehele ziekenzorg de psychiatrie en de poliklinische ziekenzorg werden geïntegreerd met de overige ziekenzorg. Een uniform leiderschap werd opgelegd aan 23 landstingen en de drie gemeenten buiten de landstingen Malmö, Götenborg en Gotland" (Socialdepartementet, 295, p. 44). In de nota van de Socialstyrelsen over de struktuur van de $Z$ weedse gezondheidszorg in de jaren tachtig (300), uitgebracht in 1976, en te vergelijken met de Nederlandse Struktuurnota gezondheidszorg (Ministerie van $V \& M, 68$ ) wordt hetzelfde gesteld.

Een samenvatting van de genoemde nota (Socialstyrelsen, 300) begint als volgt: "In de zestiger jaren is de verantwoordelijkheid voor grote delen van de gezondheidszorg overgebracht van de nationale overheid naar de landstingen. Dit betrof voornamelijk de districtsartsen en de geestelijke gezondheidszorg (....). Gedurende vele jaren zijn de landstingen reeds verantwoordelijk voor de algemene ziekenhuizen en voor de overige districts-gezondheidszorg, waaronder vallen wijkverpleging en vroedvrouwen. De hierbovengenoemde veranderingen hebben de basis gelegd voor een complete integratie van de gehele gezondheidszorg".

Ook andere publikaties spreken over de reorganisatie in de jaren zestig als voorwaarde voor integratie van de verschillende soorten gezondheidszorg (Berfenstam, 249, p. 14 en 15, Craford, 258, Engel, 265, p. 74, Socialstyrelsen, 294, Tottie, 310, p. 9 en Blanpain, 128, p. 169 e.v.).

In 1967 wordt door de voorzitter van de Landstingförbundet, Fridolf Thapper, gesignaleerd, dat zeer waarschijnlijk ook de academische ziekenhuizen van het rijk naar de landstingen zullen overgaan (Tottie, 310). In 1977 is men daar echter nog mee bezig, zo bleek uit de interviews in Uppsala en Stockholm en uit de rijksbegroting voor de volksgezondheid voor het jaar 1977 (Socialdepartementet, 294).

\subsection{BESLUITVORMINGSSTRUKTUUR VAN DE GEZONDHEIDSZORG}

\subsubsection{Besluiten over aktiviteiten en capaciteiten}

Het vaststellen van diagnose, behandeling, medicatie en verwijzen van de individuele patiënt is zowel in 1950 als in 1975 eer zaak van de behandelende arts en de individuele patiënt. De patiënt wordt geacht, behalve in noodsituaties een arts te raadplegen binnen zijn eigen landsting. Stockholm is ingedeeld in vijf landstingdistricten met gemiddeld elk circa 300.000 inwoners. Patiënten, woonachtig in zo'n district, horen naar een arts te gaan binnen hun eigen district. Een arts wordt geacht te verwij- 
zen naar een collega binnen de eigen landsting of landstingdistrict. Uitzonderingen zijn echter mogelijk.

Het funktiepakket van een werkeenheid en de afbakening hiervan ten opzichte van andere werkeenheden werd in 1950 voor de eerstelijn en de psychiatrische ziekenhuizen vastgesteld door het ministerie. Voor de algemene ziekenhuizen gebeurde dit door de landsting. In 1975 doet de landsting dit voor alle zorg. Zo bleek tijdens het onderzoek dat in 1976 in de Stockholmse landsting de vraag speelde of de obstetrie moest worden geconcentreerd in een beperkt aantal - grote - ziekenhuizen vanwege het dalend aantal geboortes. Na uitvoerige discussies over de argumenten voor en tegen (grotere mogelijkheden voor het behoud en de opbouw van professionele vaardigheden versus geringere toegankelijkheid voor de patiënt), werd door de landsting besloten dit niet te doen.

Het funktiepakket van de gehele landsting wordt in 1975 door de landstingen zelf vastgesteld. Vanaf 1967 stellen zij hiervoor vijfjarenplannen op.

De oyerzichten voor geheel Zweden werden aanvankelijk RUPRO's - running prognose - genoemd. Vanaf 1972 werden deze aktiviteitenplannen samengevoegd met de begrotingen van de financiële middelen. Het overzicht voor geheel Zweden van deze geïntegreerde landstingsplannen wordt $L K E L P$ genoemd (Landstings Kommunal Ekonomisk Långtids Planering) (Landstingförbundet, 276). Naast de vijfjarenplannen zijn de landstingen in 1972 gestart met het opstellen van plannen voor een periode van tien à vijftien jaar. Deze plannen bevatten alleen ramingen over aktiviteiten en voorzieningen (bedden, aantal artsen). Het Spri-rapport, nr. 5, 1976 geeft een samenvatting van zestien in 1976 gereed zijnde plannen van landstingen voor de periode 1974 - 1985 (SPRI, 301). De landstingen hebben deze plannen opgesteld op basis van de struktuurnota "De gezondheidszorg. in de jaren tachtig" (Socialstyrelsen, 300) en nadere richtlijnen van de Socialstyrelsen.

De Socialstyrelsen becommentarieert deze plannen voordat ze dienen als uitgangspunt voor het vijfjarenplan (zie bijvoorbeeld Socialstyrelsen, 298). Het jaarbudget van een landsting bevat naast financiële gegevens aktiviteitenramingen voor het komende jaar. Het komt in de volgende paragraaf nader aan de orde.

De landstingen beslissen autonoom over de meeste arbeidsplaatsen per werkeenheid en in de landsting als geheel. Ditzelfde geldt voor de verdeling van huisvestingsruimte van deze werkeenheden en voor de aanschaf van ziekenhuisapparatuur, waaronder de zeer geavanceerde, zoals scanners. Voorafgaande toestemming is nodig van de Socialstyrelsen voor uitbreiding van het aantal arbeidsplaatsen voor artsen, tandartsen en vroedvrouwen als ook voor nieuwbouw voor intramurale voorzieningen. De arbeidsvoorwaarden van alle werknemers, waaronder de artsen, van de landstingen worden op nationaal niveau vastgesteld.

Voor het herverdelen van bestaande arbeidsplaatsen voor artsen in bestaande gebouwen heeft de landsting geen toestemming nodig. Het aantal artsen, dat jaarlijks op de arbeidsmarkt komt, wordt bepaald door de capaciteit van de medische faculteiten en van die voor de opleiding van arts-assistenten.

In een drie partijen overleg tussen de Socialstyrelsen, Landstingförbundet en de Zweedse Medische Associatie, te vergelijken met de Koninklijke Nederlandse Maatschappij ter bevordering van de Geneeskunst (KNMG), wordt jaarlijks het aantal te creëren arbeidsplaatsen voor afstuderende artsen verdeeld per landsting en per specialisme. Als resultaat van deze onderhandelingen verschijnen het inventariserend rapport Läkares arbetstider och tjänster afgekort LATT $(L A T T, 277)$ en een daarop gebaseerd voorstel voor deze verdeling (Socialstyrelsen, 297). Bij het opstellen van de voorstellen worden geen formuletoewijzingen gebruikt. Wel zijn overwegingen bij de toewijzing, de mate waarin een landsting reeds in een bepaald specialis- 
me is voorzien, als ook de landelijke prioriteitstelling ten aanzien van soorten zorg. Iedere landsting dient tweemaal per jaar voorstellen in bij de Socialstyrelsen voor uitbreiding van de medische staf. De Socialstyrelsen keurt deze aanvragen al dan niet goed op basis van kriteria, afgeleid van de LATT en de erbij horende algemene voorstellen.

Voor nieuwbouw van voorzieningen is toestemming nodig van de Socialstyrelsen, indien de investering groter is dan 300.000 Zweedse kronen (anno 1978). Deze toestemming wordt in principe verleend door de Nationale Raad voor de Arbeidsmarkt en het Ministerie van Financiën (Navarro, 288, p. 140). Deze beide volgen in de praktijk echter altijd het advies van de Socialstyrelsen. Officieel wordt de Socialsty. relsen een investeringsruimte toegewezen door de Nationale Raad voor de Arbeidsmarkt. In de praktijk is deze echter zo ruim, dat door alle geinterviewde personen werd gesteld, dat een bouwplafond voor de gezondheidszorg in Zweden niet gehanteerd wordt. Kriteria voor de toestemming van investeringen worden afgeleid uit het landelijke beleid. Investeringen voor de extramurale zorg en de chronische zorg worden op dit moment gestimuleerd (Landstingförbundet, 276).

Er worden door de Socialstyrelsen geen landelijke planningskriteria gehanteerd, zoals $\mathrm{x}$ aantal bedden per 1000 inwoners per landsting.

De Socialstyrelsen heeft niet de bevoegdheid bepaalde voorzieningen te sluiten. Evenmin kan ze zelf initiatieven nemen tot nieuwbouw, indien een landsting dit nalaat. Indien de vergunning tot nieuwbouw is verleend, behoeft het bouwplan goedkeuring van een speciale commissie, waarin zitting hebben vertegenwoordigers van de Socialstyrelsen, Landstingförbundet en het SPRI. Deze commissie hanteert voor haar goedkeuring landelijk geldende, bouwkundige, standaardnormen (Navarro, 288, p. 141).

Over de organisatiestruktuur binnen een landsting beslist de landsting zelf. Over (de)centralisatie (stichten, opheffen, uitbreiden, samenvoegen en splitsen) van werkeenheden en ondersteunende diensten vindt de besluitvorming plaats bij de landsting na uitgebreide consultaties van alle belanghebbenden.

De organisatiestruktuur van de landstingen is de laatste jaren in beweging ten gevolge van de toegenomen taken en de behoefte aan geintegreerd beleid. In een aantal landstingen is zoals gezegd een vorm van subregionalisatie ingevoerd al (Stockholm) dan niet met eigen budget (Norrbotten). In de andere landstingen wordt over nieuwe organisatievormen gedacht, aldus geinterviewden van de Landstingförbundet.

\subsubsection{Het financieringsstelsel}

De financiële middelen van de gezondheidszorg worden in Zweden beschikbaar gesteld uit vijf bronnen: het rijk, de landstingen, de gemeentes, de sociale verzekeringen en uit eigen bijdragen van patiënten. De meeste geldstromen gaan via de landstingen naar de voorzieningen. Tabel 4.3.2. bevat een overzicht van de bestedingen naar betalende instantie.

Gegevens over de eigen bijdragen van de patiënten staan er niet in vermeld, omdat deze niet beschikbaar waren. Het aandeel van het rijk neemt af van $39 \%$ in 1950 naar $17 \%$ in 1975 . In 1975 nemen de volksverzekeringen en de landstingen $18 \%$ resp. $65 \%$ van de kosten van de gezondheidszorg voor hun rekening. Deze percentages waren in $19500 \%$ resp. $41 \%$. De gemeentes zijn vanaf 1955 te verwaarlozen voor de financiering van de gezondheidszorg. 
Totaal Rijk Volksver- Landsting Gemeente zekering

\begin{tabular}{lrllll}
\hline 1950 & & $39 \%$ & - & $41 \%$ & $20 \%$ \\
1954 & 1279,5 & $40 \%$ & - & $42 \%$ & $18 \%$ \\
1960 & 2391,3 & $25 \%$ & $16 \%$ & $59 \%$ & - \\
1965 & 4751,7 & $23 \%$ & $13 \%$ & $64 \%$ & - \\
1970 & 11173,4 & $19 \%$ & $13 \%$ & $68 \%$ & - \\
1971 & 12702,7 & $18 \%$ & $13 \%$ & $69 \%$ & - \\
1972 & 13750,3 & $22 \%$ & $13 \%$ & $65 \%$ & - \\
1973 & 14921,8 & $18 \%$ & $16 \%$ & $66 \%$ & - \\
1974 & 18118,5 & $18 \%$ & $18 \%$ & $64 \%$ & - \\
$1975^{1}$ & 21761,2 & $17 \%$ & $18 \%$ & $65 \%$ & - \\
\hline
\end{tabular}

Bron: $\operatorname{SOS}$ (307).

1 1975: opgave Socialstyrelsen, planeringsbyro̊ 3.

Hieronder volgt een bespreking van de financiering anno 1975 van de verschillende betalende instanties.

De rijksoverheid betaalt een bijdrage in de kosten van de psychiatrische gezondheidszorg en keert extra financiële middelen uit aan de landstingen met lage belastinginkomsten. Toen de landstingen in 1967 de geestelijke gezondheidszorg overnamen van het rijk, was daaraan de voorwaarde verbonden dat het rijk de kosten van dat moment voor haar rekening zou blijven nemen. Dit bedrag - geindexeerd voor prijsstijgingen en regelmatig verhoogd in verband met vernieuwingen in deze sektor wordt door het rijk jaarlijks aan de landstingen uitgekeerd.

Omdat de belastinginkomsten per landsting en per hoofd van de bevolking kunnen verschillen, keert de Zweedse rijksoverheid aan de armere landstingen extra financiële middelen uit. Bovendien keert de rijksoverheid aan de noordelijke gebieden extra financiële middelen uit vanwege de hogere kosten voor de zorgverlening in verband met het koude klimaat en de lage bevolkingsdichtheid. Dit egalisatiesysteem is uit te leggen aan de hand van onderstaande formule.

$\mathrm{t}_{\mathrm{i}} \quad$ : belastingvoet van een landsting

$Y_{\mathrm{ti}}:$ belastbaar inkomen van een landsting

$\mathrm{T}_{\mathrm{i}} \quad$ : belastinginkomsten van een landsting : $\mathrm{t}_{\mathrm{i}} \cdot \mathrm{Y}_{\mathrm{ti}}$

$\overline{\mathrm{t}}_{\mathrm{i}} \quad$ : gemiddelde belastingvoet van alle landstingen

$\Sigma \mathrm{Y}_{\mathrm{ti}}$ : belastbaar inkomen van alle landstingen

$\mathrm{P}_{\mathbf{i}} \quad$ : bevolkingsomvang in een landsting

$\Sigma P_{i} \quad$ : gehele $Z$ weedse bevolking

$\Sigma \mathrm{T}_{\mathrm{i}} \quad$ : totale belastinginkomsten van alle landstingen $: \overline{\mathrm{t}} \cdot \mathrm{Y}_{\mathrm{ti}}$

Gegarandeerd worden aan de landstingen belastinginkomsten per inwoner, die $95 \%$ bedragen van het bedrag dat de landsting zou ontvangen, indien het belastbaar inkomen per hoofd van de bevolking gelijk zou zijn aan het gemiddelde belastbaar inkomen van alle $Z$ weden. Indien een landsting te weinig ontvangt, wordt het verschil bijgepast door het rijk. "Teveel inkomsten" worden niet van een landsting afgenomen. In formule luidt de extra uitkering voor 1975: 
Extra-uitkering $1975: 95 \% \cdot P_{i} 74 \cdot \frac{\left(\overline{t_{i} 75} \cdot \Sigma Y_{t i} t_{i} 75\right)}{\left(\frac{\Sigma P_{i} 74}{(}\right)}-P_{i} 74 \cdot t_{i} 75 \cdot Y_{t i} 75^{*}$

Voor de koudere en dunbevolkte gebieden geldt een hoger percentage dan 95\%, tot een maximum van $130 \%$ voor Norrbotten.

Bij navraag bij het Landstingförbundet bleken de percentages van $95 \% \mathrm{t} / \mathrm{m} 130 \%$ niet gebaseerd te zijn op economische studies over het verband tussen de kosten van de gezondheidszorg aan de ene kant en de temperatuur en bevolkingsdichtheid aan de andere kant. Er is zelfs geen studie gemaakt, of de verschillen in het uitkeringspercentage wel evenredig zijn aan de verschillen in temperatuur en bevolkingsdichtheid.In wezen zijn de gebruikte percentages het resultaat van een politiek afwegingsproces.

Uit het fonds van de sociale verzekeringen worden extramurale en poliklinische aktiviteiten gefinancierd. Dit gebeurt op basis van alleen het eerste consult. De landsting ontvangt per eerste consult een bepaald bedrag én uit het sociale verzekeringfonds én als eigen bijdrage van de patiënt. Voor een eerste medisch consult ontvangt de landsting in 1978113 kronen, 93 van de sociale verzekeringen en 20 als eigen bijdrage van de patiënt. Vervolgconsulten, röntgen- en laboratoriumonderzoek worden niet apart gehonoreerd, maar zijn in het tarief voor het eerste consult inbegrepen. Vóór 1970 was dit niet het geval. Toen betaalden patiënten en verzekeringsinstellingen voor elke verrichting een bepaald bedrag aan de arts. De patiënt betaalde meestal 10 kronen, waarvan hij dan $75 \%$ kon declareren bij de sociale verzekeringsinstelling (Navarro, 288, p. 58).

In 1975 werd $18 \%$ - of bijna 4 mld. kronen - van de kosten van de gezondheidszorg betaald door de sociale verzekeringen. De helft hiervan was voor medische consulten in de open zorg. Eenderde betrof het medicijngebruik in de open zorg. Het resterende zesde deel ging naar diverse kleinere posten, waarvan die voor het hotelmatig verblijven in het ziekenhuis de grootste is ( $300 \mathrm{mln}$. kronen). De particuliere artsen ontvangen hun honorarium rechtstreeks van de sociale verzekeringsfondsen. Vanaf 1 november 1977 ontvangt de particuliere arts voor een gewoon consult 30 kronen en voor een bijzonder consult 43 kronen. Een consult bij een particulier gevestigd specialist kost 60 à 271 kronen. Ook deze tarieven worden voor een klein deel betaald door de patiënt zelf (meestal 15 kronen).

De landstingen hebben naast de inkomsten van het rijk en de sociale verzekeringen eigen belastinginkomsten. Het belastingtarief is rechtevenredig met het inkomen. De hoogte ervan verschilt per landsting. Het hoogste tarief in 1975 kent Stockholm $(12,75 \%)$, het laagste de landstingen Kopparbergs (W), Alvsborgs (P) en Västmanlands (U) (9,5\%) (Landstingförbundet, 275). Een hoog c.q. laag belastingtarief gaat niet altijd samen met hoge en lage kosten voor de gezondheidszorg per hoofd van de bevolking. Sommige landstingen - Stockholm - zijn namelijk ook verantwoordelijk voor het openbaar vervoer. Voor slechts 13 van de 23 landstingen gaat een relatief hoog c.q. laag belastingtarief samen met relatieve hoge en lage kosten voor gezondheidszorg per hoofd van de bevolking (Landstingförbundet, 275, tabellen 2.3.6., 2.3.7. en 2.3.8.).

Van hun inkomsten verwierven de landstingen in $197560 \%$ uit eigen belastingen. De uitkeringen op grond van het hierbovengenoemde egalisatiesysteem bedroegen $6,5 \%$ van de inkomsten. Voor de rijksbijdrage in de kosten van de psychiatrische gezondheidszorg bedraagt het percentage $12,3 \%$. De overige inkomsten van de landstingen kwamen hoofdzakelijk van patiënten en van de sociale verzekeringen. Van de uitgaven van de landstingen ging in 1975 85\% naar de gezondheidszorg. De overige uitgaven betroffen onderdelen van de maatschappelijke dienstverlening $(4,2 \%)$ 
en van het onderwijs (3,9\%) (Landstingförbundet, 275).

De opstelling van de jaarlijkse begroting van een landsting voor de exploitatie en de investeringen lijkt op die van de lokale overheid in Nederland. De totale begrotingscyclus duurt ongeveer tien maanden. In december geeft het uitvoerend orgaan de landsting richtlijnen voor de berekening van het meerjarenbudget (vijfjaarsbudget) van de verschillende organen en districten binnen de landsting. In februari dienen deze organen hun meerjarenbudget in bij het uitvoerend orgaan, dat in maart beslist over de economische randvoorwaarden van het meerjarenbudget. Op basis van deze randvoorwaarden en de ingediende meerjarenbudgetten stelt de afdeling financiën van de landsting een ontwerp-meerjarenbudget op in de maanden maart en april. In mei beoordeelt het uitvoerend orgaan dit budget, wijzigt deze eventueel en brengt deze uit als voorstel aan de raad van de landsting. Eveneens in mei geeft het uitvoerend orgaan richtlijnen voor het opstellen van de begroting voor het volgende jaar. In juni stelt de raad van de landsting de meerjarenbegroting vast en doen de verschillende organen in de landsting voorstellen voor de begroting van het komende jaar aan het uitvoerend orgaan. In de maanden juli $\mathrm{t} / \mathrm{m}$ september stelt de afdeling financiën een ontwerpbegroting op voor het komende jaar. $Z_{i j}$ legt dit voor aan het uitvoerend orgaan, die het dan al dan niet gewijzigd voorlegt aan de raad van de landsting. Deze raad stelt dan in oktober de begroting vast voor het jaar dat begint op 1 januari (zie Egelstedt, 262, p. 7 en Malmöhus Läns Landsting, 281, Uppsala Läns Landsting, 311).

In de jaarbegroting heeft iedere afdeling van elke instelling een eigen boekhoudkundige rekening, waarop personeel naar kategorie en salarisschaal, de sociale lasten en overige kosten worden geboekt. Ieder ziekenhuis heeft zijn eigen totaal-budget. Soms wordt een jaarbegroting voor districten als totaal opgesteld, zo bleek ons uit interviews in de Stockholmse landsting.

In de jaarbegroting wordt een onderscheid gemaakt tussen bestaande en nieuwe aktiviteiten en bestedingen. De nieuwe zaken krijgen, met name nieuwe arbeidsplaatsen en investeringen, de grootste aandacht en kunnen alleen doorgang vinden, indien ze zijn opgenomen in de meerjarenplannen. Naar bestaande aktiviteiten wordt nauwelijks gekeken (Borgenhammer, 251, p. 5.17 en 5.86).

Binnen de ziekenhuizen worden per specialisme afdelingen onderscheiden. De hoofdarts van zo'n afdeling is sinds 1972 verantwoordelijk voor de totale medische, financiële organisatorische gang van zaken (Borgenhammer, 254, Brody, 255 en De Greve, 266). Deze afdelingen dienen een begroting in bij de eigen ziekenhuisdirectie (zie ook De Greve, 266). Deze voegt deze samen tot één begroting voor het gehele ziekenhuis, die daarna bij de landsting wordt ingediend. De begrotingen van de landstingen alsmede aktiviteitenplannen worden volgens een uniform registratiesysteem opgesteld, zodat een onderlinge vergelijking mogelijk is (Wennström, 312). Door het vaststellen van de begroting wordt de werkeenheid geautoriseerd tot het doen van uitgaven. De feitelijke betaling vindt dan meestal plaats rechtstreeks door de financiële afdeling van de landsting. De instelling fiatteert alleen de te betalen rekeningen en salarissen.

De financiële relatie tussen de ziekenhuisarts en de landsting is te vergelijken met die in Engeland tussen de ziekenhuisarts en het DMT. De medische specialist ontvangt zijn salaris van de landsting, waarover de onderhandelingen op nationaal niveau worden gevoerd. Voor veranderingen in de infrastruktuur - huisvestingsruimte, apparatuur en medewerkers - moet de medisch specialist toestemming vragen aan de landsting. Hierbij geldt, dat de gewenste veranderingen van de individuele arts eerst op afdelings- en blokniveau, vervolgens op ziekenhuisniveau en dan pas op landstingsniveau worden bekeken. Een van de uitgangspunten hierbij is dan dat de 
wensen passen in het meerjarenplan en in de jaarbegroting. Voor medische middelen zoals medicijnen en verband, worden formeel begrotingen opgesteld. Deze begrotingen zijn evenwel open budgetten, dat wil zeggen, ze kunnen zonder voorafgaande toestemming worden overschreden.

\subsection{DOELSTELLINGEN GEZONDHEIDSZORG}

\subsubsection{Niveau en kwaliteit handhaven}

Sinds 1950 is ook in Zweden de zorgverlening aanzienlijk toegenomen. Het aantal consultaties in de open zorg was in 1975 zowel in de eerstelijnszorg als in de ziekenhuispoliklinieken meer dan het dubbele van dat in 1950 (zie tabel 4.4.1.1.). Het aantal opnames in algemene ziekenhuizen steeg in de onderzoeksperiode van 0,8 naar 1,2 miljoen, of wel van 11,6 naar 15,8 per 1000 inwoners. Ook de overige intramurale voorzieningen worden door een groeiend aantal opnames gekenmerkt: psychiatrische ziekenhuizen van 19.800 naar 122.400 opnames per jaar; verpleeghuizen van 13.300 naar 55.900 opnames voor somatische zieken, en van 1300 naar 5600 opnames voor geestelijk gestoorde bejaarden. Het aantal opnames in zwakzinnigeninrichtingen verdubbelde van 1600 in 1950 naar 3100 in 1975. De opnamegroei van de intramurale instellingen ging gepaard met een vrijwel gelijkblijvende bezettingsgraad van circa $80 \%$ voor de algemene en psychiatrische ziekenhuizen en circa $90 \%$ voor de andere instellingen (zie tabel 4.4.1.). De gemiddelde ligduur in algemene ziekenhuizen daalde van 15,8 naar 9,9 dagen. Om de groei in de zorgverlening mogelijk te maken nam het aantal arbeidskrachten sinds 1950 toe van 81.200 tot 200.600 , of wel van 11,5 naar 24,6 per 1000 inwoners. Het aantal artsen is in 1975 meer dan het dubbele dan dat in 1950. Dit wordt veroorzaakt door een verdrievoudiging van het aantal artsen in intramurale instellingen en een verdubbeling van het aantal artsen in de eerstelijn. In de eerstelijn werken naast de particuliere artsen in 19751600 algemene_artsen (te vergelijken met de Nederlandse huisarts) als districtsarts en 1100 specialisten (Nicolausson, 290), waarvan een deel als part-timers. Het aantal tandartsen is in 1975 het dubbele van dat in 1950. Het aantal gediplomeerde verpleegkundigen is in het eerstgenoemde jaar bijna een viervoud van dat in 1950. Het aantal wijkverpleegkundigen steeg gedurende de onderzoeksperiode van 1264 naar 1941. Het aantal apothekers daalde van 900 naar 730. De groeiende intramurale aktiviteiten zijn mogelijk geworden door een groeiend aantal bedden: van 90.600 in 1950 naar 136.400 in 1975 , of wel van 14,0 naar 16,9 bedden per 1000 inwoners. Deze groei is te herleiden tot hoofdzakelijk een groei van de bedden van somatische verpleeghuizen. Het aantal bedden - ook dat per 1000 inwoners - in algemene ziekenhuizen daalt gedurende de onderzoeksperiode.

In Zweden zijn in 1975 acht algemene ziekenhuizen met meer dan duizend bedden, 26 met 500 tot 1000 bedden en 89 met minder dan 500 bedden. Hierbij zij opgemerkt dat deze ziekenhuizen naast acute, somatische, ook psychiatrische en chronische zorg verlenen. De 19 zelfstandige psychiatrische ziekenhuizen zijn gemiddeld 809 bedden groot. Bovenstaande 156 grote intramurale instellingen nemen $64 \%$ van het totaal aantal verpleegdagen voor hun rekening. Naast deze 156 werkeenheden telt de Zweedse gezondheidszorg nog 724 kleinere instellingen, bestaande uit ziekenhuizen, verpleeghuizen en instellingen voor zwakzinnigen. De gemiddelde omvang ervan is 67 bedden. In de loop der jaren is in Zweden een schaalvergroting opgetreden. De gemiddelde omvang van alle intramurale instellingen steeg van 100 bedden in 1950 naar 155 bedden in 1975. Die van ziekenhuizen inclusief verpleeghuizen steeg over deze periode van 97 naar 216 bedden. (Bovenstaande gegevens 
Tabel 4.4.1.1. Aktiviteiten en voorzieningen van de Zweedse gezondheidszorg 1950 1975

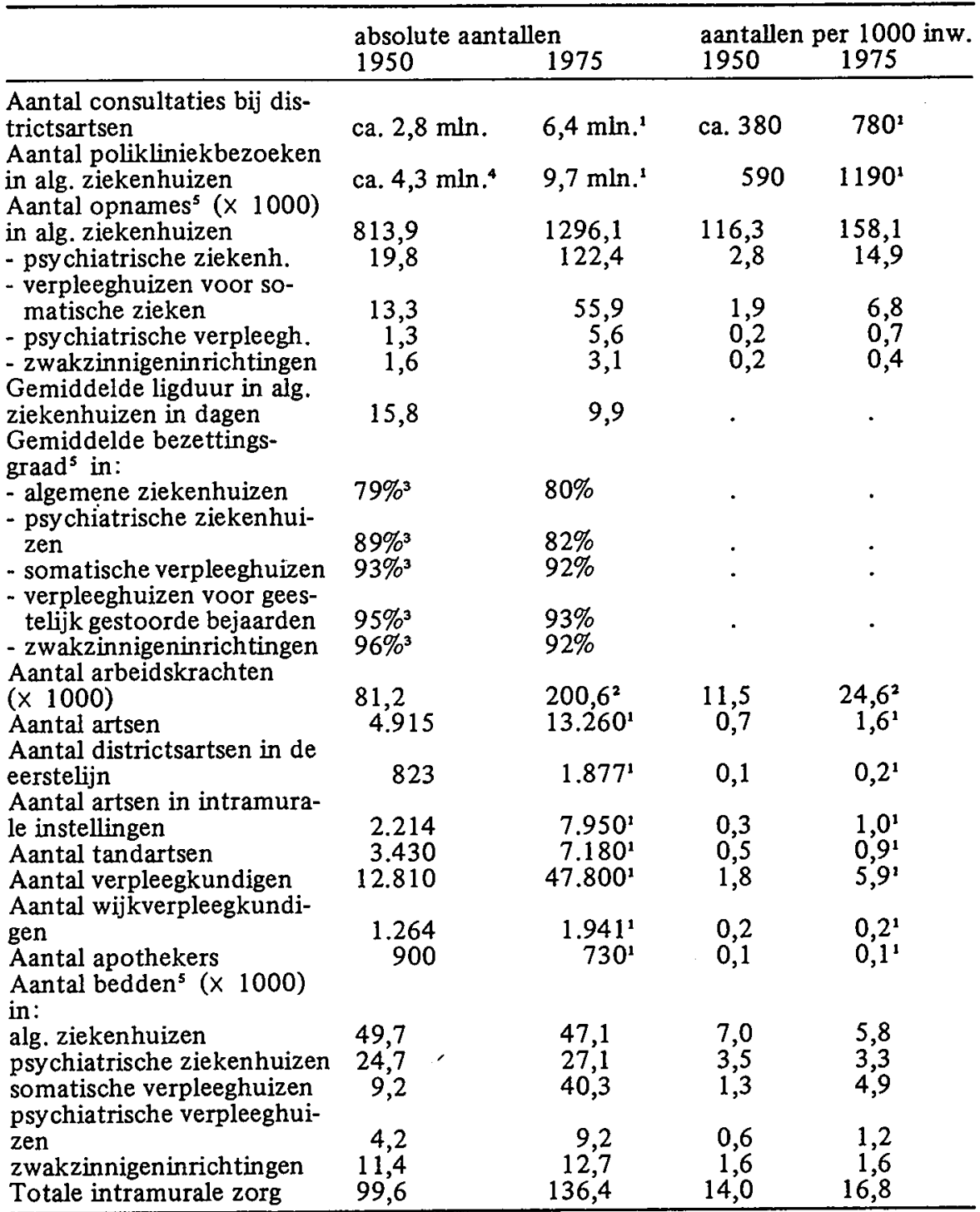

Bron: SOS (307) en opgave Socialstyrelsen.

11974.

21973.

31954.

41955

5 De indeling volgt niet het type ziekenhuis maar het type zorg: Psychiatrische bedden in een algemeen ziekenhuis worden bijvoorbeeld gerekend onder "psychiatrische ziekenhuizen". 
zijn verstrekt door de Socialstyrelsen). Voor de periode tot 1985 wordt een verdere aktiviteitengroei gepland. Uit de lange termijnplannen van de landstingen (19741985) alsmede uit de vijfjarenplannen (1977-1982) blijkt, dat deze een uitbreiding van de extramurale zorg betreft (4\% meer consulten per jaar), en de verpleeghuiszorg $(4,9 \%$ meer bedden per jaar). De algemene ziekenhuizen $(0,2 \%$ minder bedden per jaar) en de psychiatrische instellingen ( $1,0 \%$ minder per jaar) blijven op vrijwel constant niveau.

Het aantal artsen in de open zorg moet jaarlijks met $8,2 \%$ groeien en dat in de intramurale sektor met $4,6 \%$. De investeringen in beide sektoren, als percentage van de totale investeringen, moeten achtereenvolgens groeien van $4 \%$ in 1975 naar $10 \%$ in 1979, resp. van 63\% in 1975 naar $67 \%$ in 1979. Deze laatste groei bestaat vooral uit toenemende investeringen in verpleeghuizen (Landstingförbundet, 276).

Dat het niveau van de verleende zorg in alle opzichten voorziet in de behoeften van de Zweedse bevolking is niet te stellen. In patiëntenenquêtes (zie paragraaf 4.4.5.) wordt geklaagd over het gebrek aan continuiteit in de zorgverlening. In de open zorg kennen de patiënten geen eigen arts. In verschillende publikaties wordt de Engelse en Nederlandse huisarts aanbevolen om in dit gebrek te voorzien (Dahlin, 260, Lithman en Schersten, 279).

Over de toegankelijkheid van de zorg is op te merken, dat er wachttijden bestaan voor vooral de open zorg (Nicolausson, 290 en Lapré, 278). Genoemd worden afspraaktermijnen van twee maanden voor poliklinische consulten en van 2,5 à 3 weken voor consulten bij districts- en particuliere artsen (Clade, 257). Voor opname voor interne geneeskunde in algemene ziekenhuizen bestaan kortere wachttijden. Op 31 december 1975 is het aantal patiënten op de wachtlijst hiervoor $2 \%$ van het totaal aantal opnamen in 1975. Dit houdt een gemiddelde wachttijd in van ongeveer één week. Voor chirurgische opnamen is de wachtlijst $11 \%$ en de gemiddelde wachttijd circa vijf weken. Voor acute opnamen zijn geen wachttijden (Socialstyrelsen, 299).

Van patiënten wordt een eigen bijdrage geïnd van 15 à 20 kronen per consult. Bij geinterviewden in dit onderzoek bestond niet de indruk, dat dit bedrag bezwaarlijk was voor patiënten. Het is de prijs van één bezoek aan de kapper, zo werd gesteld. Als oorzaken van de aktiviteitengroei worden door Zweedse bronnen genoemd de bevolkingsgroei en de uitbreiding van bepaalde kategorieën zorgvragenden, zoals de toename van het aantal bejaarden (congres Landstingförbundet 1975, Lapré, 278). Verder wordt gewezen op de ontwikkeling van de medische kennis (Socialdepartementet , 295) en van het Bruto Nationaal Produkt van Zweden (Ståhl, 303).

Behalve door de hiergenoemde faktoren werd de groei van bepaalde aktiviteiten ook beïnvloed door het financieringsstelsel.

In verschillende interviews werd gewezen op het verband tussen de sterke groei van de intramurale zorg en de verantwoordelijkheid hiervoor van de landstingen. Dit in tegenstelling tot de geringe groei van het stelsel van de districtsartsen, waarvoor de verantwoordelijkheid tot 1967 bij de rijksoverheid lag. Ter illustratie van deze ontwikkelingen dient het volgende overzicht:

\begin{tabular}{l|l|c|c|c}
\hline & \multicolumn{2}{|l|}{$\begin{array}{l}\text { artsen in in tramu- } \\
\text { rale instellingen }\end{array}$} & \multicolumn{2}{l}{ districtsartsen } \\
\hline & $\begin{array}{l}\text { absoluut } \\
\text { aantal }\end{array}$ & index & $\begin{array}{l}\text { absoluut } \\
\text { aantal }\end{array}$ & index \\
\hline 1950 & 2214 & 39 & 823 & 78 \\
1967 & 5698 & 100 & 1060 & 100 \\
1974 & 7950 & 140 & 1877 & 177 \\
\hline
\end{tabular}


Het aantal artsen in intramurale instelling was in $195039 \%$ en in $1974140 \%$ van dat in 1967. Het aantal districtsartsen bedroeg in $195078 \%$ en in $1974177 \%$ van dat in 1967.

Als verklaring voor deze groeiverschillen wordt niet alleen de sterke ontwikkeling van de medische mogelijkheden in ziekenhuizen opgegeven maar ook de financieringswijze. De belastinginkomsten van het rijk stegen in de jaren zestig naar verhouding minder dan die van de landstingen (zie tabel 4.4.1.2.). Dit wordt enerzijds veroorzaakt doordat de door de burger betaalde landstingbelasting tot 1969 aftrekbaar was van het belastbaar inkornen voor de rijksbelastingen. Dit houdt in, dat de landstingen hun tarieven gemakkelijker konden verhogen, omdat de burger deze verhoging gedeeltelijk kon compenseren met een verlaging van zijn te betalen rijksbelasting.

Bovendien waren volgens verschillende geinterviewden de belastingtarieven van het rijk meer een onderwerp van politieke discussie dan die van de landstingen. De politieke druk tegen belastingverhoging van het rijk leek aldus groter te zijn geweest dan bij de landstingen. Als gevolg hiervan konden de algemene ziekenhuizen, betaald door de landstingen, zich minder geremd ontwikkelen dan de extramurale zorg, die onder de verantwoordelijkheid van het rijk viel. Na 1967 is ook deze laatste zich sterker gaan ontwikkelen.

Tabel 4.4.1.2. Belasting-inkomsten naar overheid

\begin{tabular}{lccll}
\hline & 1960 & 1965 & 1970 & 1974 \\
\hline Rijk & 75,6 & 73,3 & 69,1 & 67,6 \\
Landstingen & 4,9 & 6,5 & 8,8 & 11,2 \\
Gemeenten & 19,5 & 20,2 & 22,1 & 21,2 \\
Totaal & $100 \%$ & $100 \%$ & $100 \%$ & $100 \%$ \\
\hline Totaal in mld. SK. & 20,1 & 34,7 & 58,5 & 93,1 \\
\hline
\end{tabular}

Bron: $\operatorname{SOS}(309)$.

Een andere invloed van de formele, financiële besluitvormingsstruktuur wordt merkbaar door de ontwikkeling van de open zorg - districtsartsen-en poliklinische zorg te volgen voor en na de zeven-kronen hervorming in 1970.

Deze verandering werd in 1970 ingevoerd, zoals gezegd in par. 4.2.1. en 4.3.2., om het bestuur van de open zorg te vereenvoudigen, de toegang tot de open zorg voor de patiënten goedkoper te maken, alle financiële transakties tussen arts en patiënt te elimineren en om een zelfde salarisschaal in te voeren voor alle medische specialismen (Navarro, 288, p. 58 en verder, zie ook par. 4.2.1.).

Grafiek 4.4.1. 1. laat zien, hoe het aantal poliklinische patiënten van algemene ziekenhuizen zich van 1965 tot en met 1974 ontwikkelde. Van 1965 tot 1969 stijgt het niveau van 2,7 mln. naar 3,1 mln. Dit is een gemiddelde toename per jaar van 100.000 poliklinische patiënten.

Van 1969 op 1970 is er sprake van een toename van 400.000 nieuwe patiënten. Deze eenjarige toevloed van nieuwe patiënten duidt op een samenhang met de zevenkronen hervorming. Omdat deze nieuwe patiënten niet in bestaande poliklinieken konden worden opgevangen, daalde het aantal consulten per patiënt en werden de 


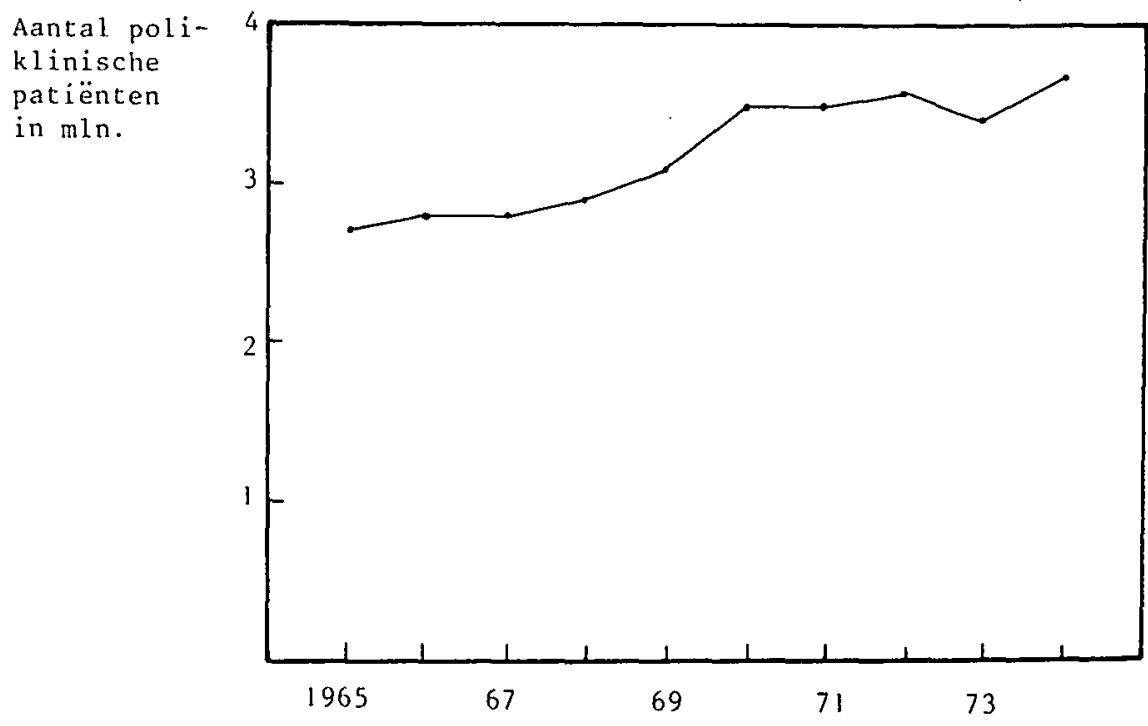

Bron: $\operatorname{SOS}(307)$

wachtlijsten van 1969 op 1971 aanmerkelijk langer (Clade, 257). Vanaf 1970 ligt het aantal poliklinische patiënten op een niveau van circa $3,5 \mathrm{mln}$. Op vragen over de zeven-kronen hervorming werd in de interviews door verschillende beleidsfunktionarissen van de Socialstyrelsen en de landstingförbundet ook gewezen op het effekt ervan op de landstingen.

Door een betaling per verrichting wordt de planning van deze aktiviteiten van een landsting niet afgeremd door beschikbare financiële middelen. Immers elke aktiviteitengroei betaalt dan zichzelf. Ook in gesprekken met beleidsfunktionarissen van de landstingen Malmöhus en Stockholm bleken deze overwegingen in de beleidsbepaling mee te spelen.

Dat de beschikbaar gestelde financiële middelen een limiet vormen voor de aangeboden zorg door de individuele artsen, is in de interviews niet gebleken. Bij de open zorg is deze limiet niet aanwezig: zoals gezegd leiden meer aktiviteiten tot meer financiële middelen. Bij de intramurale zorg is meestal niet zozeer het toegewezen budget een limiet, maar de beschikbare medewerkers. Omdat er onvoldoende artsen, verpleegkundigen en andere medewerkers aan te trekken zijn, is het gebrek aan deze een beperkende voorwaarde voor de aktiviteitenomvang. Van de aktiviteitenplanning als zodanig lijkt geen remmende werking uit te gaan op de feitelijke aktiviteitenontwikkeling. In de periode van $1973 \mathrm{t} / \mathrm{m} 1976$ was deze laatste gemiddeld $20 \%$ hoger dan de geplande (Stähl, 303).

\subsubsection{Afremming kostengroei}

De totale kosten van de Zweedse gezondheidszorg bedragen in 1975 meer dan 20 
mld. SK (Zweedse kronen) ofwel 7,6\% van het Bruto Nationaal Produkt (BNP) (zie tabel 4.4.3.1.). In 1975 is het bedrag bijna twintig maal zo hoog als in 1953 en bijna tweemaal zo hoog als in 1970 (1954: 10, 1970: 100, 1975: 195).

Vooral in de jaren zestig groeiden de uitgaven van de gezondheidszorg snel (19601965: 20\% per jaar en 1965-1970: 27\% per jaar). In deze jaren stijgt het aandeel in het BNP van 3,3\% naar 6,1\%. Ten gevolge van de bevolkingsgroei stijgen de kosten per jaar 1 à $2 \%$ (tabel 4.4.2.1.).

Tabel 4.4.2.1. Kosten Zweedse gezondheidszorg 1948 - 1975

\begin{tabular}{lcllll}
\hline & $\begin{array}{l}\text { Absoluut } \\
\text { bedrag in } \\
\text { mln. sK. }\end{array}$ & $\begin{array}{l}\text { Absoluut } \\
\text { bedrag } \\
1970=100\end{array}$ & $\begin{array}{l}\text { Gemiddelde } \\
\text { groei \% } \\
\text { per jaar }\end{array}$ & $\begin{array}{l}\text { Gemiddelde } \\
\text { groei per jaar } \\
\text { per inwoner }\end{array}$ & $\begin{array}{l}\text { Als \% } \\
\text { van het } \\
\text { BNP1 }\end{array}$ \\
\hline 1950 & $1.279,5$ & 10 & $15 \%$ & $13 \%$ & - \\
1960 & $2.391,3$ & 21 & $20 \%$ & $18 \%$ & $3,3 \%$ \\
1965 & $4.751,7$ & 43 & $27 \%$ & $25 \%$ & $4,2 \%$ \\
1970 & $11.173,4$ & 100 & $14 \%$ & $13 \%$ & $6,6 \%$ \\
1971 & $12.702,7$ & 114 & $8 \%$ & $8 \%$ & $6,9 \%$ \\
1972 & $13.750,3$ & 123 & $9 \%$ & $8 \%$ & $6,9 \%$ \\
1973 & $14.921,8$ & 134 & $21 \%$ & $21 \%$ & $6,8 \%$ \\
1974 & $18.108,5$ & 162 & $20 \%$ & $20 \%$ & $7,3 \%$ \\
$1975^{2}$ & $21.761,2$ & 195 & - & - & $7,6 \%$ \\
\hline
\end{tabular}

Bron: SOS (307), Landstingförbundet (273).

1 Bruto Nationaal Produkt tegen marktprijzen.

2 1975: Opgave Socialstyrelsen planeringsbyrỏ 3.

- Niet beschikbaar.

Tabel 4.4.2.2. Investeringen in de $Z$ weedse gezondheidszorg

absoluut absoluut

bedrag in bedrag

mln. SK $1970=100$

\begin{tabular}{rrr}
\hline 1960 & 338 & 20 \\
1965 & 693 & 41 \\
1970 & 1684 & 100 \\
1971 & 1561 & 93 \\
1972 & 1505 & 89 \\
1973 & 1367 & 81 \\
1974 & 1511 & 90 \\
1975 & 1886 & 112 \\
\hline
\end{tabular}

Bron: $S O S$ (3.07).

Tabel 4.4.2.2. geeft een overzicht van de investeringen in de Zweedse gezondheidszorg vanaf 1960. Af te lezen is een daling van de investeringen na 1970. Aangezien de bedragen gemeten zijn tegen lopende prijzen is de daling gemeten in constante 
prijzen nog scherper. Bror Rexed, direkteur-generaal van de Socialstyrelsen, geeft in een voordracht aan, dat de samenstelling van de investeringen verandert. In 1963 werd $80 \%$ van de investeringen besteed aan ziekenhuizen, terwijl dat in 1972 slechts $35 \%$ bedroeg. Het aandeel van gezondheidscentra bedroeg in $197215 \%$. Dit aandeel is groeiende (Rexed, 293).

Als oorzaken van de kostenstijging zijn te noemen de groei van de aktiviteiten (zie par. 4.4.1.) en de inflatie. Omdat ook in Zweden de gezondheidszorg bijzonder arbeidsintensief is, leiden loonstijgingen zonder mogelijkheden tot verhoging van de arbeidsproduktiviteit tot grote kostenstijgingen. In 1975 zijn de kosten tegen lopende prijzen gemeten $195 \%$ van die in 1970 . Tegen constante prijzen berekend is dit percentage $119 \%$ (SOS-308).

In 1970 worden de kostenstijgingen voor het eerst in officiële stukken van de rijksoverheid als probleem gesignaleerd. De Minister van Gezondheidszorg zegt in 1970 in de begrotingsvoorstellen voor 1971: "De doelstellingen van de gezondheidszorg zijn in de afgelopen jaren gericht geweest op het bereiken van struktuurveranderingen van de Zweedse gezondheidszorg. Dit is in toenemende mate noodzakelijk geworden, vooral vanwege de kostenontwikkelingen in de gezondheidszorg" (Wictorson, 314, p. 5). Deze zienswijze, dat door struktuurveranderingen de kostengroei van de gezondheidszorg moet worden afgeremd, werd gedeeld door verschillende geïnterviewde personen en kwam terug in verschillende beleidsstukken.

Zo wordt in de rijksbegroting voor 1977 gepleit voor meer preventie en eerstelijnsgezondheidszorg om hierdoor de kosten te beperken (Socialdepartementet, 294). In wezen kunnen deze struktuurveranderingen alleen op de lange termijn de kostengroei beperken. Voor de korte termijn betekenen ze kostenverhogingen in verband met nieuwbouw van poliklinieken en eerstelijnsvoorzieningen.

Het is opvallend, dat er in het Zweedse gezondheidsbeleid niet gedacht wordt aan direkte maatregelen om de prijsontwikkeling of de volumegroei op korte termijn te beperken: de in 1976 geplande groei van de aktiviteiten en de kosten tot 1981 is niet lager dan die van de afgelopen jaren. De groei tegen constante prijzen is gelijk aan die in de periode 1970-1975: 4\% per jaar (Budgetdepartementet, 256). Geconfronteerd met het feit dat de investeringen in de gezondheidszorg gemeten in constante prijzen, vanaf 1971 toch teruglopen, deelden de geinterviewden mede, dat de oorzaak hiervan was, dat alle ziekenhuizen nu vernieuwd waren. Er was geen sprake van een bouwplafond. Illustratief voor het bovenstaande is een in juni 1977 gepubliceerd interview met de direkteur-generaal van de Socialstyrelsen, Bror Rexed. Deze antwoordt op de vraag van de interviewer Juda, of de Zweedse gezondheidszorg door een recessie zou kunnen worden aangetast:

"No, I don't think so. We would have to restrict advances in specialized areas. Of course, some people would be unhappy. I really do not think that this would lower the quality.Perhaps in some ways, the quality would increase because the well-trained district nurse is fantastic for helping people. At the moment, our most difficult problem is taking care of old people. We overspecialized and built chronic-care hospitals - typically highquality, hygienic institutions. In our forthcoming plan for the ' 80 s, we say that about 60 percent of the patients in these institutions should be transferred to small local nursing homes, which have no doctors of their own but rely on those in the primary medical care areas. That is, the doctor in the health station would take care of the out-patients and also supervise those who stay in the nursing home (...)

Juda: And this whole system would not be affected by a recession?

Rexed: Probably not, because it relise on services which are simply organized. Even in a depression I don't think we could cut them out. We might have to reduce the 
use of equipment and some types of expensive services. We might not be able to give medical gymnastics to everybody. But we have to give them contact with somebody - the nurse, the doctor - if they are in great need. We might have to send more people to nurses and restrict the access to doctors and to central hospitals" (Juda, 268).

De maatregelen die wel genomen zijn door het rijk en de landstingen om op korte termijn de kosten af te remmen zijn van indirekte aard, dat wil zeggen niet rechtstreeks gericht op het beperken van de aktiviteitenomvang of de middelenomvang.

Te noemen zijn:

- vanaf 1972 worden de aktiviteiten en de financiële planning niet meer afzonderlijk, maar als een geheel opgesteld door de landsting.

- vanaf 1973 onderhandelt het rijk met de landstingen en de gemeenten over de hoogte van de belastingtarieven van deze laatste. De rijksoverheid kocht voor de jaren 1974 en 1975 een stijging van de percentages af door extra bijdragen te leveren in de exploitatiekosten van de lokale overheden. Omdat de belastingen van de lagere overheid evenredig en die van het rijk progressief zijn, drukt op deze wijze de lastenverhoging minder op de lagere inkomensgroepen (mededelingen landstingförbundet).

Voor de jaren 1976 en 1977 kwamen de lagere overheden met het rijk overeen het belastingpercentage met niet meer dan $10 \%$ voor deze twee jaren tezamen te doen stijgen. De regering kwam hierbij tegemoet met een extra-uitkering. Een voorwaarde van de lagere overheden hierbij was de mogelijkheid tot heropenen van de onderhandelingen in het voorjaar 1977 indien de economische situatie anders zou zijn dan voorspeld (Landstingförbundet, 271).

Voor 1978 zijn er geen afspraken gemaakt, maar heeft de Landstingförbundet zelf aan de landstingen verzocht, de groeipercentages voor de bestedingen tot 1982 met 1/3 van de groei boven 3\% te beperken. Uit interviews bleek dat de landstingen zich hieraan wilden houden. Of de landstingen in staat zijn de kostenontwikkelingen geheel binnen de gestelde budgetten te houden is te betwijfelen.

In 1975 werkten de Stockholmse ziekenhuizen met grote budgetoverschrijdingen (Karlson, 270, Brody, 255). De hierdoor ontstane financiële tekorten moesten in de volgende jaren alsnog uit de inkomsten van de landstingen worden gedekt. Na 1975 zijn in Stockholm de procedures voor begrotingsbewaking en goedkeuring van bestedingen verbeterd. Toch worden er volgens geïnterviewden nog steeds personen aangesteld op niet goedgekeurde posten. Deze posten worden "zwarte" of bij een gedeeltelijke goedkeuring "grijze" posten genoemd (zie Borgenhammer, 251, p. 5:6).

In 1976 is door een rijkscommissie met een gemengde samenstelling een onderzoek gestart naar de financiering van de lagere overheden (Budgetdepartementet, 256, Wetterberg, 313). Het onderzoek moet nagaan, welke maatregelen er nodig zijn om binnen het raam van voor de rijksfinanciën aanvaardbare condities een gewenste ontwikkeling van de financiën van de lagere overheden te bereiken (Budgetdepartementet, 256, p. 11). Zowel het totaalbedrag als de verdeling van de rijksbijdragen aan de gemeenten en de landstingen dient te worden bekeken. In het eindrapport van het onderzoek dat uitkwam eind 1977, wordt de autonomie en de kostenontwikkeling positief beoordeeld in verband met de werkgelegenheidspolitiek (Wetterberg, 313 , p. 33). Het huidige egalisatiesysteem voor de belastingen wil de commissie enigszins veranderen (Wetterberg, 313, p. 51 en verder).

Voor de landstingen betekent dit, dat het bestaande systeem het beste in grote lij- 
nen gehandhaafd kon blijven. Slechts één wijziging is volgens de onderzoekscommissie noodzakelijk: de spreiding van de basisuitkering van $90 \% \mathrm{t} / \mathrm{m} 130 \%$ moet kleiner worden. In plaats van $90 \%$ moet de laagste uitkering daarom $103 \%$ worden, terwijl de hoogste klasse $136 \%$ moet bedragen. Tussen deze twee uitersten worden twaalf klassen gecreëerd, die steeds $3 \%$ van elkaar verschillen. De plaatsing van een landsting in een klasse gebeurt op basis van een vergelijking met de gemeenten, berekeningen over inwerking van de geografische ligging en bebouwingsstruktuur van de landsting en gegevens over de financiële positie en de aktiviteiten van de landsting. Op deze uitkering krijgen landstingen met een ongunstige leeftijdsopbouw een extra toeslag, die jaarlijks in absolute bedragen wordt berekend.

De invoering van deze verandering kost het rijk 2,7 mld. SK, indien deze in 1977 zou plaats vinden. Van deze extra-uitkeringen zouden vooral Zuidzweedse gemeenten en landstingen profiteren. Geen enkele landsting of gemeente zou in uitkering achteruitgaan. In interviews met funktionarissen van de landstingen Malmöhus, Stockholm en Norrbotten werd dit onderzoek aanvankelijk van groot belang geacht. De kans, dat de voorstellen zouden worden doorgevoerd door de regering achtte men achteraf gering in verband met de kosten ervan. Een verdere beperking van de kostengroei van de gezondheidszorg op korte termijn lijkt onvermijdelijk, omdat de vooruitzichten voor de economische groei van $Z$ weden zeer somber zijn. Een extrapolatie van kostenstijging over de periode $1970-1975$ - die reëel $4 \%$ en nominaal $20 \%$ per jaar bedroeg - en van de ontwikkeling van het BNP over dezelfde periode levert een beslag op van het eerstgenoemde van $8,8 \%$ van het BNP in 1980 en 10,3\% in 1985.

Dit is alleen mogelijk indien het aandeel in het BNP voor de partikuliere consumptie en de overige overheidsbestedingen zal dalen.

Het vergroten van het aandeel van het BNP is echter volgens de begroting 1977 (Ministry of Economic Affairs, 283) en verschillende geinterviewden moeilijk politiek te realiseren. Het ontbreekt de regering echter aan de mogelijkheden en het parlement aan de wil, om via een rijksbeleid hierop te anticiperen. Een wetsvoorstel in 1977 dat de regering bevoegdheden moest geven om de tarieven van de belastingen van de lokale overheden aan een maximum te binden, vond onvoldoende steun in het parlement.

\subsubsection{Evenwichtige geografische spreiding}

In grafiek 4.4.3.1. staan de exploitatiekosten in 1975 vermeld van de consumptie van gezondheidszorg van de inwoners van de landstingen. De kosten zijn eerst uitgedrukt in een bedrag per hoofd van de bevolking van de betreffende landsting. Dit bedrag is daarna omgerekend als percentage van het landelijk gemiddelde per hoofd van de bevolking. Dit laatste bedraagt in 19752195 SK. Uit grafiek 4.4.3. komen als "duurste" en "goedkoopste" gebieden naar voren Götenborg (OG) met 125 en Västmanlands (U) met 81. De grote steden Stockholm, Malmö en Götenborg vertonen hogere kosten dan het landelijk gemiddelde. De noordelijke landstingen geven beide meer uit dan het landelijk gemiddelde. Uitsplitsing van de kosten naar intramurale en extramurale instellingen levert ongeveer dezelfde spreiding. Götenborg (OG) geeft het meeste uit aan intramurale voorzieningen, namelijk $25 \%$ meer dan het landelijk gemiddelde van 1861 SK. Västmanlands (U) zit er $20 \%$ onder en is daarmee de landsting met de minste kosten.

Op het gebied van de extramurale zorg geeft Västerbottens (AC) het meeste uit per hoofd van de bevolking, $146 \%$ van het landelijk gemiddelde van 233 SK. De stad Malmö heeft de laagste kosten: 41\% van 233 SK. Van de 23 landstingen zijn er vier die relatief lage intramurale kosten paren met relatief hoge extramurale kosten. Voor 
Grafiek 4.4.3.1. Kosten van de landstingen voor de gezondheidszorg per hoofd van de bevolking als \% van het national gemiddelde

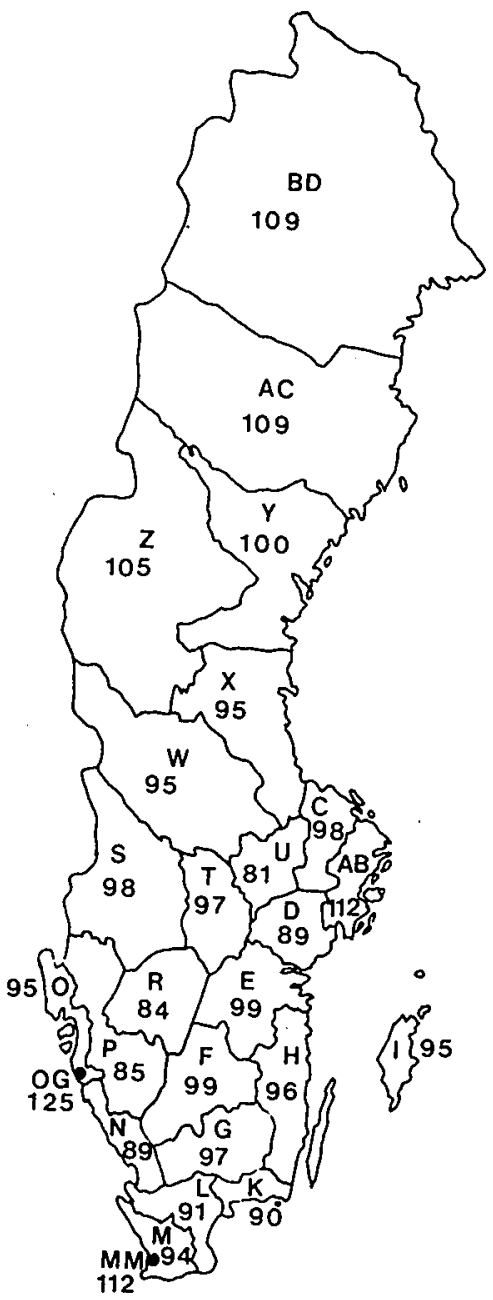

Bron: Landstingförbundet (275)

Verklaring lettercode: zie grafiek 1.3.2.2. op p. 14 
één landsting en twee grote gemeentes geldt het verband "relatief hoge intramurale kosten en relatief lage extramurale kosten". Voor de meeste landstingen zijn de intra- en extramurale kosten tegelijk laag c.q. hoog. (Alle gegevens uit: Landstingförbundet, 275, tabel 2.3.4.).

Uit deze gegevens komt de indruk naar voren, dat de landstingen in grote mate zelfstandig hun beleid ten aanzien van hun eigen regio kunnen bepalen. Dit is in tegenstelling tot de mening van verschillende Nederlandse bezoekers aan de Zweedse gezondheidszorg, die aangeven dat de Socialstyrelsen grote invloed heeft op het landelijke gezondheidsbeleid en dat de door Zweden zelf genoemde autonomie van de landstingen niet veel betekent (Lapré, 248, Dokter-de Leeuw, 261 en Centrale Raad voor de Volksgezondheid, 259).

Immers de instrumenten die de Socialstyrelsen bezit om het beleid te beinvloeden zijn indrukwekkend. Voor het aantrekken van nieuwe artsen en voor het doen van nieuwe investeringen is toestemming nodig van de Socialstyrelsen. Daarnaast heeft een landsting ook nog toestemming nodig om in een willekeurig ziekenhuis bepaalde funkties te laten uitvoeren.

Uit de bovengenoemde gegevens komen desondanks vrij grote verschillen naar voren in de bestedingen per inwoner van de landstingen. Een verklaring hiervoor ligt in het feit, dat de Socialstyrelsen niet zelf investeringen kan initiëren of arbeidsplaatsen scheppen, als de landsting zelf geen aktief beleid voert. Een ander punt is, dat de Socialstyrelsen niet binnen het funktiepakket kan herschikken: ze mag alleen nieuwe investeringen en nieuwe arbeidsplaatsen van artsen beoordelen. Tenslotte worden in Zweden bij het beoordelen van investeringsplannen en het benodigd aantal arbeidsplaatsen voor artsen géén landelijke normen gehanteerd.

Deze normen bleken ook bij navraag bij de Landstingförbundet en de Socialstyrelsen niet beschikbaar. Wel zijn er duidelijke visies en beleidspunten op struktureel gebied, zoals de versterking van de eerstelijnszorg en de verpleeghuizenzorg (zie par. 5.6.). In de interviews is regelmatig gevraagd naar de relatie tussen de Socialstyrelsen en de landstingen. Opvallend waren de verschillen in beantwoording. Soms was de eerste een papieren tijger, dan weer de laatste. Bij alle interviews met de beleidsfunktionarissen van de landstingen bleek wel steeds een sterk gevoel van autonomie aanwezig en werd de Socialstyrelsen en soms ook de Landstingförbundet als bedreigend ervaren. Soms waren de antwoorden vergelijkbaar met die van funktionarissen van instellingen van het partikulier initiatief in Nederland, die externe organen voor de gezondheidszorg beoordelen. Op basis van de statistische gegevens en de indrukken uit de interviews, moet de relatie van de Socialstyrelsen en de landstingen worden gezien als zeer subtiel van aard. De invloed van de eerstgenoemde op het voorzieningenbeleid is hierbij groter dan op het spreidingsbeleid. Vooral de spreiding van artsen over de landstingen is op dit moment in Zweden een probleem. Immers het gaat niet alleen om het toewijzen van nieuwe posten, maar ook om het vervuld krijgen van een nieuwe post. Zo werd in een interview verteld, dat Jämtlands (landstingaanduiding: $Z$ ) vele posten voor oogartsen had toegewezen gekregen, maar dat slechts één post bezet was. De meeste artsen, zo werd meegedeeld, willen niet naar het platteland, terwijl juist daar de bevolking veroudert. Omdat de koude onaantrekkelijke landstingen geen hogere salarissen mogen bieden aan artsen, wordt er door de landstingen alleen geconcurreerd in de tertiaire arbeidsvoorwaarden. Hierbij is te denken aan gunstige faciliteiten om een huis te bouwen of te kopen en aan gunstige bijscholingsmogelijkheden. Op deze wijze weten sommige landstingen, zoals Norrbotten in het uiterste noorden, hun posten beter bezet te krijgen dan anders.

Overigens bedroeg het gemiddelde aantal vakatures voor artsen in ziekenhuizen $10 \%$ van het aantal arbeidsplaatsen ( $S O S, 307)$. 
Gegevens over het aantal vervulde arbeidsplaatsen per landsting waren niet te krijgen, ondanks herhaalde verzoeken. Waarschijnlijk is de relatieve spreiding hiervan nog onevenwichtiger dan die van het aantal, inclusief vakatures.

\subsubsection{Integratie zorgverlening}

In paragraaf 4.3. is aangegeven, dat in de jaren zestig vrijwel de gehele gezondheidszorg onder verantwoordelijkheid is gekomen van de landstingen. Thans is er sprake van een groeiende afstemming tussen voorzieningen.

In vele landstingen zijn of worden subregio's (districten) gevormd ten behoeve van de verdere integratie van de zorgverlening (Landstingforrbundet, 274). Ook komt het in toenemende mate voor dat artsen én als districtsarts én als ziekenhuisarts werken. Kleinere instellingen lijken gebaat te zijn met de regionale strukturen in verband met schaalvoordelen van ondersteunende diensten. Ze kunnen gebruik maken van regionale inkoop-, personeels-, huisvestings- en opleidingsafdelingen. Een ander belangrijk verschijnsel waaruit een groei van de integratie is af te leiden, is de planning van het totaal pakket van aktiviteiten van een landsting. In gesprekken met funktionarissen van de Socialstyrelsen kwam naar voren, dat de lange termijnplannen voor de periode 1974 - 1985 voor de eerste keer de gehele zorgverlening omvatten. Hierdoor wordt het mogelijk in deze plannen een prioriteit te geven aan chronische patiënten en eerstelijnszorg.

De integratie van de zorgverlening in Zweden is een ontwikkelingsproces, waarvoor de hervormingen in de jaren zestig de basis hebben gelegd. Navarro, die een uitgebreid en diepgaand onderzoek heeft gedaan naar de struktuur van de Zweedse gezondheidszorg komt tot de waarschuwende opmerking, dat eenheid van bestuur wel een noodzakelijke, maar niet een voldoende voorwaarde is voor integratie van de zorg: "In view of this experience it again would seem that integration under one administration, although necessary, is not sufficient, and that other administrative arrangements, such as the establishment of health teams may be required to achieve adequate integration of the provision of care. In this respect it should be emphasized that the various primary care health workers in Sweden do not work as health teams" (Navarro, 288, p. 71).

Zowel bij planningsaktiviteiten als in de zorgverlening wordt de relatie met de maatschappelijke dienstverlening door verschillende geinterviewden als problematisch ervaren. De verschillen in opname-beleid van bejaardenoorden van de gemeenten en de verschillende financiële regelingen voor de verzorgden aldaar en de verpleegden in verpleeghuizen worden hierbij genoemd. Gepleit wordt voor eenheid van bestuur van én gezondheidszorg én maatschappelijke dienstverlening, waarvan de laatste op dit moment bestuurlijk onder de gemeenten valt (zie ook Swedish Commission on Social Welfare, 305). Omdat dit echter als zeer moeilijk wordt beschouwd, wordt in ieder geval een goede taakverdeling en gelijke verzorgingsgebieden bepleit (Dahlin, 261).

Met dit laatste wordt op dit moment in Tierp, een plaats in de landsting Uppsala, -geëxperimenteerd (Karlson, 269, Berfenstam, 249).

\subsubsection{Vergroten betrokkenheid van patiënten en medewerkers}

\subsubsection{Ontwikkeling satisfactie van patiënten en medewerkers}

In 1974 is in de Zuidzweedse landsting Malmöhus een onderzoek naar de tevredenheid met de gezondheidszorg gehouden onder 761 inwoners. Op de vraag "Wat is het belangrijkste voor $u$, als u een arts bezoekt?" konden de geinterviewden uit vijf antwoordkategorieën twee keuzes maken. Dit leverde het volgende beeld op (Ejlert- 
son, 263, p. 313, zie ook Ejlertson, 264).

antwoordkategorie

"dat hij veel tijd heeft"

"dat ik ter plaatse niet lang hoef te wachten"

"dat ik iedere keer dezelfde arts heb"

"dat de arts een specialist is op het gebied

van mijn ziekte"

"dat ik hem dichtbij mijn huis of werk kan bezoeken" percentage

$50,6 \%$

$24,9 \%$

$69,6 \%$

$34,9 \%$

$17,0 \%$

De behoefte aan iedere keer dezelfde arts blijkt het hoogste te scoren $(69,6 \%)$. Gevraagd naar de algemene tevredenheid blijkt $44 \%$ tevreden, $18 \%$ neutraal en $9 \%$ ontevreden te zijn, terwijl de overigen geen specifieke attitude hebben ten opzichte van de gezondheidszorg. De meeste geuite individuele klachten blijken het gebrek aan continuiteit te zijn en de lange wachttijden. Lars Dahlin komt op basis van een onderzoek in Malmö-län tot dezelfde bevindingen (Dahlin, 260). Een onderzoek van de Zweedse Medische Associatie in 1974 geeft aan, dat er bij patiënten wel vertrouwen bestaat dat men voldoende wordt geholpen bij een ernstige ziekte (Hjern, 267). De regering heeft een commissie ingesteld in 1976 om het vraagstuk van de continuiteit in de zorgverlening aan de patiënt te onderzoeken (Socialdepartementet, 294). Gedacht wordt zowel aan organisatorische oplossingen als aan een hogere personeelsbezetting.

De Zweedse medische professie lijkt tevreden met de bestaande organisatiestruktuur van de gezondheidszorg. In 1976 stelt de direkteur van de Zweedse Medische Associatie, Hjern: "I am convinced that only a small minority of the Swedish physicians would prefer to go back to the system of compensation for services rendered; $(. .$.$) .$ The problem that troubles the Swedish doctors most today is the increased administrative bureaucracy in health care (...). I think it is correct to say, that the existing displeasures among Swedish physicians today does not so much have its origin in conditions within the health and medical care proper but that the discontent as a matter of fact is directed towards many other phenomena in the development of society, above all towards the progressive, and in the income levels of the physicians, clearly confiscating taxation system" (Hjern, 267).

Uit de interviews en het hieronder vermelde artikel komt als knelpunt wel naar voren het gebrek aan verpleegkundig personeel in de intramurale sektoren, met name in de verpleeghuizen. Dit gebrek is vooral nijpend in de zomermaanden. Signalen over deze tekorten kwamen in dit onderzoek uit Örebro-län (Monvall, 286), Värmland-län (Mo̊rtens, 282), Stockholm-län (Björk, 253) en van de organisatie voor verpleegkundigen (Björk, 250, 252). Verder werd keer op keer door geinterviewden geklaagd over de hoge direkte belastingen op het inkomen. Deze zijn sterk progressief. Hierdoor is er een sterke drang bij artsen, verpleegkundigen en anderen om overwerk niet te compenseren tegen inkomen, maar tegen vrije tijd. Dit leidt dan aldus tot weer minder continuiteit in de zorg en tot langere wachttijden voor patiënten.

\subsubsection{Inspraak voor patiënten en medewerkers}

Ook in Zweden worden, net als in Engeland, uitgebreide consultatierondes gehouden, voordat belangrijke besluiten worden genomen. De Centrale Raad voor de Volksgezondheid beschrijft deze in een verslag over een bezoek aan de Zweedse gezondheidszorg als volgt:

"Zonder een poging te doen hier verder op de werkwijze van het geheel in te gaan, 
mag gesteld worden, dat zich daar een kompleks van beleidswoorbereidende en beleidsuitvoerende aktiviteiten afspeelt, waarbij overleg en inspraak hoogtij vieren. Het geheel wekt de indruk dat enerzijds niets en niemand in dit gebeuren tekort wordt gedaan, doch dat anderzijds de gang van zaken zeer tijdrovend is, zodat de besluitvorming uit het oogpunt van slagvaardigheid ongunstig moet worden beinvloed" ( $C R V, 259$, p. 22-23).

Ondanks het hoogtij vieren van overleg en inspraak komt uit de interviews in dit onderzoek de indruk naar voren, dat patiënten of hun vertegenwoordigers weinig betrokken worden bij de besluitvorming. Desgevraagd werd vaak geantwoord, dat de patiënt eens in de drie jaar het bestuur van de landsting kan kiezen. Tussentijdse raadplegingen van patiëntengroepen lijkt weinig voor te komen. Ook het in andere maatschappelijke sektoren aanwezige instituut van ombudsman, werd in de bezochte landstingen niet aangetroffen.

De invloed van politici lijkt ook gering, zij het dat deze wel toeneemt. In verschillende interviews kwam het beeld naar voren van de politicus, die alles wil, en de deskundige manager/ambtenaar die de rationele beslissingen neemt.

Deels door de regionalisatie sinds de jaren zestig, deels ook als autonome ontwikkeling is in de landstingen wel een toenemende invloed van de volksvertegenwoordigers waar te nemen. Vroeger waren de dagelijkse bestuurders part-timers, nu fulltimers. Vroeger ging de diskussie in de landsting meer over de belastingtarieven. Nu komt het inhoudelijke deel van de gezondheidszorg meer aan de orde, zo werd in interviews met funktionarissen van de landstingen Norrbotten, Malmöhus en Stockholm meegedeeld. De direktere en snellere kontakten met politici en bestuurders sinds de reorganisaties werden in interviews met verschillende praktizerende artsen als positief ervaren. 


\section{REGIONALISATIE EN FINANCIERING VAN DE NEDERLANDSE GEZONDHEIDSZORG}

\subsection{ALGEMENE KENMERKEN VAN NEDERLAND}

5.1.1. Demografische en macroeconomische kenmerken In Nederland wonen in 197513,7 miljoen inwoners (zie tabel 5.1.1.1.). In 1950 was dit aantal 10,2 miljoen. Verwacht wordt in 1990 een bevolkingsomvang van 14,2 miljoen. De Nederlandse bevolking vergrijst: was het percentage bejaarden in de bevolking in $19507,7 \%$, in 1975 is dit gestegen tot 10,9\%. In 1990 wordt een aandeel verwacht van $12,7 \%$. Deze veroudering hangt samen met een dalend geboortecijfer: in 1950 werden 22,7 kinderen geboren per 1000 inwoners. In $1975 \mathrm{zijn}$ dat er 13,0 en in 1990 volgens de prognoses 11,8. De bevolkingsdichtheid bedraagt in 1950270 , in 1975400 en naar verwachting in 1990420 inwoners per $\mathrm{km}^{2}$.

Tabel 5.1.1.1. Demografische en macro-economische kenmerken in Nederland

\begin{tabular}{|c|c|c|c|}
\hline & 1950 & 1975 & $\begin{array}{l}\text { verwachting } \\
1990\end{array}$ \\
\hline $\begin{array}{l}\text { Bevolkingsomvang in mln. } \\
\text { - waarvan } 65 \text { en ouder } \\
\text { Aantal levend geborenen per } 1000 \text { inwoners } \\
\text { Bevolkingsdichtheid (aantal inwoners per } \\
\mathrm{km}^{2} \text { ) } \\
\text { Totaal arbeidsvolume in } 1975 \\
\text { - waarvan landbouw en visserij } \\
\quad \text { industrie en delfstoffenwinning } \\
\quad \text { overige sektoren } \\
\text { Bruto Nationaal Produkt tegen marktprijzen } \\
\text { in guldens (BNP) } \\
\text { BNP tegen constante prijzen (1970=100) } \\
\text { Prijsindexcijfer van de gezinsconsumptie } \\
\text { (1970 = 100) }\end{array}$ & $\begin{array}{c}10,2 \\
7,7 \% \\
22,7 \\
270\end{array}$ & $\begin{array}{l}13,7 \\
10,9 \% \\
13,0 \\
400 \\
4,7 \% \\
6,4 \% \\
33,7 \% \\
59,9 \% \\
209,4 \\
117 \\
154\end{array}$ & $\begin{array}{l}14,2 \\
12,7 \% \\
11,8 \\
420\end{array}$ \\
\hline
\end{tabular}

Bron: $C B S(17,21$ en 22).

Nederland kent een parlementaire democratie met vrije ondernemingswijze produktie, die globaal door de rijksoverheid wordt geordend. De werkzame beroepsbevolking bestaat uit 4,0 miljoen personen. Hiervan werkt $6,4 \%$ in de primaire sektor, $33,7 \%$ in de industrie en de overigen $(59,9 \%)$ in de dienstverlenende sektoren. Het Bruto Nationaal Produkt tegen marktprijzen bedraagt in 1975 209,4 mld. gulden, ofwel $f 15.200$ per inwoner. Het is dan tienmaal zo hoog als in 1950. Gemeten in 
constante prijzen is het $\mathrm{BNP}$ in 1975 bijna driemaal zo hoog als in 1950 . Dit houdt in een groei van $3,2 \%$ per jaar. Het prijsindexcijfer van de gezinsconsumptie is in 1975 ruim drie maal zo hoog als in 1950, hetgeen neerkomt op een gemiddelde jaarlijkse prijsstijging van circa $4,5 \%$.

Sinds 1974 beleeft Nederland de zwaarste na-oorlogse recessie. Bedraagt de gemiddelde reële groei van het BNP sinds $19504 \%$, voor de periode 1973.1977 bedraagt deze groei $2,2 \%$. Deze stagnerende groei gaat gepaard met een groeiende werkloosheid en een inflatie, die groter is dan gemiddeld sinds 1950, zoals uit tabel 5.1.1.2. blijkt.

Tabel 5.1.1.2. Werkloosheid en inflatie in Nederland 1970-1977

\begin{tabular}{|c|c|c|}
\hline & $\begin{array}{l}\text { Geregistreerde werklozen } \\
\text { als percentage van de } \\
\text { totale beroepsbevolking }\end{array}$ & $\begin{array}{l}\text { Jaarlijkse stijging van het } \\
\text { prijsindexcijfer voor de } \\
\text { gezinsconsumptie }\end{array}$ \\
\hline $\begin{array}{l}1970 \\
1974 \\
1975 \\
1976 \\
1977\end{array}$ & $\left.\begin{array}{l}0,9 \% \\
2,8 \% \\
4,0 \% \\
4,3 \% \\
4,2 \%\end{array}\right\}$ & $\begin{array}{r}7,0 \% \\
11,1 \% \\
9,0 \% \\
7,3 \%\end{array}$ \\
\hline
\end{tabular}

Bron: $C B S(21)$.

De koers van de Nederlandse gulden stijgt in deze jaren. Is in 1970 honderd gulden 27,6 US \$ waard, in 1977 is dit 40,8 US \$. Ten gevolge van deze waardevermeerdering, alsmede van de ongunstige ontwikkeling van de loonkosten per eenheid produkt vergeleken met buitenlandse concurrenten, neemt in de jaren 1974 tot en met 1978 het aandeel van de Nederlandse export in de wereldinvoer met ruim $10 \%$ af. De lopende rekening van de Nederlandse betalingsbalans vertoont in 1976 nog een overschot van 7,5 mld. gulden. In 1977 is dat overschot geslonken tot $1 \mathrm{mld}$.gld. en in 1978 tot 0,5 mld. gulden. Exclusief de aardgaswinning zou in dat laatste jaar de lopende rekening een tekort vertonen van 4 à 5 mld. gulden (zie uitvoerig: Miljoenennota 1979,66, p. 10-20). Om de recessie het hoofd te bieden brengt de regering-Den Uyl, bestaande uit socialisten en christen-democraten, in juni 1976 de nota Collectieve Voorzieningen en de Werkgelegenheid (24) uit. Op basis van deze nota wordt het beleid van deze regering erop gericht, de reële groei van de collectieve druk te beperken van $1,75 \%$ tot $1 \%$ van het nationaal inkomen. Tevens voert deze regering een beleid om vooral via gerichte maatregelen bepaalde bedrijfstakken te ondersteunen. $\mathrm{Na}$ een regeringswisseling in 1977 brengt de regering-Van Agt, bestaande uit christen-democraten en conservatieve liberalen in 1978 de nota Bestek 81 (10) uit. Deze nota bepleit een verdere afremming van de collectieve druk dan voorgesteld door het kabinet-Den Uyl. Het beleid wordt erop gericht om meer via algemene dan via gerichte maatregelen de lasten van het bedrijfsleven te verlichten.

\subsubsection{Gezondheidstoestand van de bevolking}

De gemiddelde levensverwachting van mannen stijgt van 1950 tot 1975 met tien maanden (0,8 jaar) en wel van 70,6 naar 71,4 jaar (zie tabel 5.1.2.). Voor vrouwen bedraagt deze stijging bijna vijf jaar: van 72,9 naar 77,6 jaren. De perinatale sterfte 
en de sterfte aan infectieziekten dalen beide aanzienlijk gedurende de onderzoeksperiode. Het mortaliteitspatroon wijkt voor 1975 af van dat in 1950: in het eerstgenoemde jaar sterft $70 \%$ van de bevolking aan kwaadaardige nieuwvormingen of hart- en vaatziekten. In 1950 is dat percentage $38 \%$. Andere kriteria voor de gezondheidstoestand van de Nederlandse bevolking zijn recentelijk beschikbaar gekomen uit een onderzoek van het $C B S$ (16): op grond van de antwoorden van een representatieve steekproef van 4800 Nederlanders bleek in 1974, dat $47 \%$ van de bevolking aan langdurige aandoeningen lijdt. Verder blijkt $15 \%$ en 38\% van de bevolking kortdurend ziek respectievelijk gezond te zijn geweest in 1974. Tevreden tot buitengewoon tevreden over de eigen gezondheid blijkt $79 \%$ van de bevolking van 18 jaar en ouder te zijn $(C B S, 16)$.

Tabel 5.1.2. Gezondheidstoestand van de bevolking in Nederland

$1950 \quad 1975$

Gemiddelde verwachte levensduur

in jaren bij de geboorte:

van - mannen

- vrouwen

Perinatale sterfte per 1000 inwoners

Mortaliteit per 100.000 inwoners

- infektieziekten

- kwaadaardige nieuwvormingen

- hart- en vaatziekten

- overige ziekten

$\begin{array}{cc}70,6^{1} & 71,4 \\ 72,9^{1} & 77,6 \\ 34,2 & 13,9 \\ 750 & 833 \\ 35 & 6,5 \\ 92 & 216 \\ 196 & 372 \\ 402 & 239\end{array}$

Bron: $C B S$ (16 en 23).

$11950-1952$.

\subsubsection{Organisatie van het overheidsbestel}

Naast de rijksoverheid kent Nederland per 1 januari 1977 elf provinciale en 842 gemeentelijke overheden.

Het inwonertal van de provincies varieert van 335.000 (Zeeland) tot drie miljoen (Zuid-Holland) en bedraagt gemiddeld 1,3 mln. De grootste provincies beslaan 5100 $\mathrm{km}^{2}$ (Noord-Brabant en Gelderland) de kleinste $1400 \mathrm{~km}^{2}$ (Utrecht). Het gemiddelde oppervlak bedraagt $3350 \mathrm{~km}^{2}$. De taken van de provincies betreffen hoofdzakelijk de ruimtelijke ordening: in 1973 werd $530 \mathrm{mln}$. gulden $(53 \%$ van de totale provinciale uitgaven) besteed aan verkeer en waterstaat. Verder hebben de provincies op allerlei maatschappelijke terreinen, waaronder de gezondheidszorg, kleine deeltaken. Van de 842 gemeenten hebben 290 minder dan 5000 inwoners. Zeventien tellen meer dan 100.000 inwoners, waarvan de grootste, Amsterdam (740.000 inw.), Rotterdam (600.000 inw.), Den Haag (470.000 inw.) en Utrecht (240.000 inw.) zijn. De belangrijkste taken van de gemeenten betreffen de volkshuisvesting, ruimtelijke ordening, onderwijs, maatschappelijke dienstverlening en de uitvoering van de bijstandswet. Het takenpakket van de gemeenten is omvangrijker dan dat van de provincies. De uitgaven van de eerstgenoemden zijn in 1973 zestien maal zo hoog als die van de laatstgenoemden.

De organisatie van het binnenlands bestuur staat sinds de jaren zestig in Nederland 
ter discussie. In 1975 bracht de regering een concept-ontwerp van Wet Reorganisatie binnenlands bestuur (104) uit. Volgens dit concept zou het aantal provincies moeten stijgen van 11 naar 24 . Het aantal gemeenten zou moeten dalen. De bevoegdheden van beide lokale overheden zouden moeten toenemen door afstoting van taken door de verschillende vakdepartementen. In 1978 staat een en ander nog steeds ter discussie.

\subsection{ORGANISATIESTRUKTUUR VAN DE NEDERLANDSE GEZONDHEIDS- ZORG}

De meeste werkeenheden van gezondheidszorg in Nederland kennen een eigen bestuur. Indien dit bestuur een zelfstandige juridische rechtspersoonlijkheid bezit, dan wordt een dergelijke werkeenheid hieronder een instelling van particulier initiatief of particuliere instelling genoemd. Is een werkeenheid een onderdeel van de overheidsorganisatie dan wordt hieronder gesproken van een instelling van overheidsinitiatief dan wel van een overheidsinstelling.

Voor de extramurale instellingen zijn te onderscheiden de openbare gezondheidszorg, de maatschappelijke- en de overige gezondheidszorg. De eerstgenoemde valt onder de verantwoordelijkheid van de lagere overheden en wordt hoofdzakelijk gevormd door de Gemeentelijke Geneeskundige en Gezondheidsdiensten (GG \& GD's). Zij omvat - in de meeste gemeenten - de schoolartsenzorg, ambulancediensten, enige sociaal-psychiatrische zorg en de bedrijfsgeneeskundige dienst voor het personeel van de lagere overheid. De maatschappelijke gezondheidszorg wordt uitgevoerd door de particuliere kruisverenigingen, die in Nederland meer dan twee miljoen leden tellen. Ze omvat onder andere wijkverpleging en de consultatiebureau's voor zuigelingen en kleuters. Naast de openbare en maatschappelijke gezondheidszorg bestaan er vele andere extramurale instellingen bestuurd door particulier initiatief. Deze instellingen houden zich bezig met preventie, psychosociale hulpverlening of met hulpverlening voor een specifieke groep patiënten. Voor de bevolking van de provincie Utrecht (874.000 inwoners in 1977) zijn in 1977 circa 50 van deze extramurale instellingen werkzaam, elk met veelal minder dan veertig medewerkers (Gids Gezondheidszorg voor de provincie Utrecht, 82).

In 1975 waren er in Nederland 248 ziekenhuizen: $90 \%$ particuliere en $10 \%$ overheidsziekenhuizen (zie tabel 5.2.). De overige intramurale instellingen kennen eveneens in meerderheid een particuliere signatuur.

Tabel 5.2. Verdeling intramurale instellingen naar signatuur

\begin{tabular}{llll} 
Soort instelling & aantal & particulier & overheid \\
\hline algemene ziekenhuizen & 248 & $90 \%$ & $10 \%$ \\
psychiatrische ziekenhuizen & 72 & $87 \%$ & $13 \%$ \\
verpleeghuizen & 298 & $59 \%$ & $41 \%$ \\
zwakzinnigeninrichtingen & 128 & $98 \%$ & $2 \%$ \\
\hline
\end{tabular}

Bron: CBS (22), GHI (46) en Van Aert \& Montfort (2 en 3).

Noot: De percentages zijn benaderingen, aangezien de verschillende bronnen niet steeds op elkaar aansloten. 
De huisartsen en de medisch specialisten in algemene ziekenhuizen zijn voor het overgrote deel zelfstandig gevestigd. De laatstgenoemden sluiten een contract af met het bestuur van het ziekenhuis, waarin een aantal zaken ten aanzien van het gebruik van de ziekenhuisaccommodatie en van de inpassing in organisatie worden geregeld ( $L S V-N Z R, 65)$. In psychiatrische en zwakzinnigeninrichtingen zijn de psychiaters veelal in loondienst. De specialisten binnen een instelling zijn verenigd in de medische staf, waarin gemeenschappelijke problemen worden besproken. Veelal heeft de medische staf een stafbestuur dat regelmatig met de directie overlegt. De besturen van de instellingen zijn autonoom ten opzichte van elkaar. In vroegere jaren hadden vele werkeenheden een nauwe bestuurlijke relatie met bepaalde kerken. Tegenwoordig zijn de meeste autonoom maar dragen ze in hun naam nog de denominatie: in 1970 was ruim het derde deel (36\%) van de 254 ziekenhuizen "katholiek", $24 \%$ "protestant-christelijk", 28\% "algemeen" en 12\% "overheid" $(C B S, 22)$. Zie voor een uitvoerige beschrijving van de bestaande organisatiestruktuur Damen en Nuyens, 37 en Santema, 87.

\subsubsection{Landelijke organen}

Is de autonomie van de instellingen ten opzichte van elkaar sinds de jaren vijftig weinig veranderd, ten opzichte van het nationale beleid is er sprake van een afnemende ruimte voor het voeren van een eigen beleid. In 1975 bestaat er in Nederland een aantal advies- en besluitvormingsorganen, die elk kaders aangeven voor de instellingen op hun terrein. Te noemen zijn:

- Centrale Raad voor de Volksgezondheid (CRV). Deze raad bestaat voor $50 \%$ uit leden afkomstig uit de overheidssector en voor 50\% uit de particuliere sector. Haar taak is de samenwerking te bevorderen tussen de minister, openbare lichamen en diensten en particuliere instellingen. De Raad adviseert de minister over organisatorische vraagstukken en wettelijke regelingen op het gebied van de volksgezondheid.

- Gezondheidsraad. Deze raad is een college van advies, dat de regering, in het bijzonder de Minister van Volksgezondheid en Milieuhygiëne, voorlicht over de stand van de wetenschap ten aanzien van vraagstukken op het gebied der volksgezondheid. Het uitbrengen van adviezen geschiedt niet door plenaire bijeenkomsten, maar wordt toevertrouwd aan vaste of, in de meeste gevallen, tijdelijke commissies, die door de voorzitter van deze raad worden samengesteld uit deskundigen in en buiten de Gezondheidsraad.

- Ziekenfondsraad. Voor de uitvoering van de Zfekenfondswet telt deze raad 35 leden, zeven in elk van de vijf navolgende groepéringen: werkgevers, werknemers, ziekenfondsorganisaties, medewerkers (artsen, apothekers, tandartsen, vroedvrouwen en ziekenhuizen) en overheid. Voor de uitvoering van de Algemene Wet Bijzondere Ziektekosten (AWBZ) heeft deze raad een enigszins hiervan afwijkende samenstelling. De Ziekenfondsraad adviseert de Ministers van Sociale Zaken en van V \& $M$ over de hoogte van de premies van de Ziekenfondswet en de AWBZ. Tarieven voor fondsverzekerden hebben pas rechtsgeldigheid na goedkeuring door de Ziekenfondsraad.

- College voor Ziekenhuisvoorzieningen/Ziekenhuiscommissie (CVZ). De Ziekenhuiscommissie funktioneert krachtens de beschikking Ziekenhuiscommissie 1965, het College krachtens de Wet Ziekenhuisvoorzieningen. De samenstelling van beide organen is sinds 1972 identiek: er bestaat een personele unie. Het CVZ houdt zich bezig met de opstelling van de planning van nieuwbouw van ziekenhuizen. In het CVZ hebben zitting personen uit de kring van ziekenhuizen (negen), ziekenfondsen (vijf), particuliere ziektekostenverzekeraars (een), ambtenarenziekte- 
kostenverzekeraars (een), gemeenten (een), provincies (twee), Koninklijke Maatschappij ter Bevordering van de Geneeskunst (KNMG) (twee), Stichting van de Arbeid (twee) en een onafhankelijke deskundige. De voorzitter wordt bij Koninklijk Besluit benoemd.

- Centraal Orgaan Ziekenhuistarieven (COZ). De taak van de $\mathrm{COZ}$ is het bevorderen van het vaststellen van verantwoorde ziekenhuistarieven. Het moet bij alle prijsstellingsprocedures inzake tarieven van onder de Wet Ziekenhuistarieven vallende instellingen voor gezondheidszorg worden betrokken. Het $\mathrm{COZ}$ adviseert ten aanzien van de ziekenfondstarieven aan de Ziekenfondsraad. Particuliere tarieven krijgen rechtsgeldigheid na goedkeuring van het $\mathrm{COZ}$. Zitting in het $\mathrm{COZ}$ hebben vertegenwoordigers van de instellingen (elf), betalende instanties (elf), en provincies (een), voorts vier onafhankelijke deskundigen. (Voor een uitvoerige bespreking van bovengenoemde landelijke organen zie Van Leeuwen, 63, Postma, 80, De Roy van Zuydewijn, 83, Van der Wolf, 110 en Wagner, 99.)

\subsubsection{Te verwachten struktuur, volgens Struktuurnota Gezondheidszorg 1974}

In 1974 heeft de Nederlandse regering een beleidsnota uitgebracht over de gewenste toekomstige struktuur van de gezondheidszorg. In deze "Struktuurnota Gezondheidszorg" worden de volgende knelpunten gesignaleerd (Ministerie van $V \& M, 68$, p. 5).

1. Instrumenten voor de beheersing van de kostenontwikkeling, zowel in totaliteit als op afzonderlijke onderdelen, zijn niet of onvoldoende aanwezig. Het ontbreken daarvan maakt het slagvaardig reageren op nieuwe ontwikkelingen vrijwel onmogelijk.

2. Het stelsel van voorzieningen toont onvoldoende samenhang. De funktionele samenhang ontbreekt, zowel horizontaal als verticaal, met als gevolg een onafhankelijk van elkaar funktioneren. Dit leidt tot een inefficiënt gebruik van beschikbare personele, financiële en materiële middelen, terwijl het stelsel van voorzieningen en daardoor met name ook voor de patiënt onoverzichtelijk is.

3. De huidige struktuur van de financiering van de gezondheidszorg is verbrokkeld en onoverzichtelijk, en bevordert in bepaalde gevallen de noodzakelijke werking tussen de voorzieningen niet.

Doordat de financiering zich passief aanpast aan bestaande organisatorische verhoudingen, oefent zij geen corrigerende invloed uit op de onderlinge afstemming van voorzieningen.

4. De samenwerking tussen de instellingen voor gezondheidszorg en de andere wel-

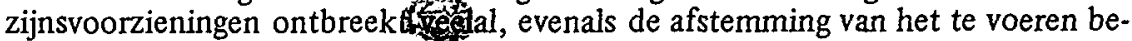
leid (planning, financiering, etc.) terzake op elkaar.

5. Het stelsel van voorzieningen vertoont onevenwichtigheden. Door de medischtechnische ontwikkeling en het financieringsstelsel van de sociale verzekering is een onevenredig grote nadruk op de intramurale sector komen te liggen. Deze kon zich tot voor kort nagenoeg ongelimiteerd uitbreiden. De extramurale zorg en preventieve zorg zijn anderzijds onvoldoende tot ontwikkeling gekomen, terwijl de sector geestelijke gezondheidszorg in ontwikkeling is achtergebleven.

6. In de intramurale sector zijn hier en daar onevenwichtigheden in de capaciteiten ontstaan. Enerzijds zijn er nog steeds knelpunten, terwijl er anderzijds te grote capaciteiten bestaan die ongewenste leegloop veroorzaken.

7. Bij de organisatie van de voorzieningen doen zich problemen voor. Enerzijds doen er zich bij bepaalde voorzieningen schaalproblemen voor, terwijl er anderzijds voorzieningen zijn van onvoldoende omvang om een aanvaardbaar dienstenpakket te leveren. 
8. De spreiding van de voorzieningen is niet altijd optimaal. Dit geldt met name voor de geestelijke gezondheidszorg.

9. De inspraak van de bevolking in de ontwikkeling van de gezondheidszorg en in het funktioneren van de voorzieningen is onvoldoende tot ontwikkeling gekomen.

Om deze knelpunten op te lossen wordt in de Struktuurnota gepleit voor een herstrukturering van de gezondheidszorg. Uitgangspunten voor de nieuwe struktuur zijn regionalisatie en echelonnering. Voor het eerste wordt gepleit om de bereikbaarheid en de continuiteit van de gezondheidszorg, de betrokkenheid van de bevolking alsmede de aansluiting op andere welzijnsvoorzieningen te bevorderen $(68$, p. 10$)$. Onder echelonnering wordt verstaan de indeling in sektoren van de gezondheidszorg, die voorzieningen omvat, die globaal gesproken dezelfde funktionele kenmerken en gerichtheid vertonen. Van deze echelonnering worden voordelen verwacht voor de ordening, beheersbaarheid, overzichtelijkheid en afstemming van de capaciteiten van de voorzieningen op elkaar $(68$, p. 13). Op basis van deze uitgangspunten worden verschillende modellen ontwikkeld voor de verschillende soorten gezondheidszorg $(68$, p. 20 en verder).

\subsection{BESLUITVORMINGSSTRUKTUUR VAN DE GEZONDHEIDSZORG}

\subsubsection{Besluitvorming over aktiviteiten en capaciteiten}

Het vaststellen van de diagnose, behandeling, medicatie en verwijzing van een individuele patiënt is ook in Nederland een zaak van de individuele arts en de individuele patiënt gezamenlijk. Welk funktiepakket wordt aangeboden door een werkeenheid wordt bepaald door het bestuur van de werkeenheid of door de voor eigen rekening werkende beroepsbeoefenaar. Voor het verrichten van sommige aktiviteiten is toestemming van nationale instanties nodig. De Wet Ziekenhuisvoorzieningen (107) geeft op basis van artikel 18 van deze Wet het Ministerie van V \& M de bevoegdheid krachtens een algemene maatregel van bestuur funkties aan te wijzen, die slechts met haar toestemming in een intramurale instelling mogen worden uitgevoerd. Voor het uitoefenen van open hartchirurgie, nierdialyse en megavolttherapie is thans een dergelijke toestemming nodig. Het ministerie geeft deze toestemming, nadat advies is ingewonnen bij het provinciaal bestuur.

Voor zover de beslissingen over de financiële middelen en de landelijk vastgestelde arbeidsvoorwaarden dit toelaten zijn de intramurale instellingen vrij in hun personeels- en arbeidsplaatsenbeleid. Zolang het ziekenhuisbestuur binnen de richtlijnen ten aanzien van de kosten en tarieven van het $\mathrm{COZ}$ blijft is het vrij te bepalen, welke funkties het wil creëren en welke medewerkers het wil aantrekken. Veelal vindt er een delegatie van de bevoegdheden hiervoor plaats aan de ziekenhuisdirectie. Het ziekenhuisbestuur bepaalt ook in de meeste gevallen het aantal specialisten en bedden per specialisme. Uitzonderingen hierop zijn de bovengenoemde funkties, die onder artikel 18 van de Wet Ziekenhuisvoorzieningen vallen. Verder is het per 15 september 1976 aan de ziekenhuisbesturen niet meer toegestaan op eigen gelegenheid het aantal specialismen uit te breiden. Dit is echter niet gebeurd via een daartoe opgestelde regeling, maar door nieuwe specialismen van een bepaald ziekenhuis niet voor honorering door ziekenfondsen in aanmerking te laten komen.

De extramurale instellingen, die een budgetfinanciering kennen (zie par. 5.3.2.), hebben voor het opvullen van een vakature veelal apart toestemming - naast die voor de begroting - nodig van de geldgever. Ook stelt de financier wel eisen aan de te creëren funkties en de organisatiestruktuur. Zo worden de Sociaal-Psychiatrische 
Diensten (SPD's) in Nederland niet alleen gefinancierd maar ook beleidsmatig gecontroleerd door de Ziekenfondsraad (Nederlandse Vereniging voor Ambulante Geestelijke Gezondheidszorg, NVAGG, 74). Veelal worden er nationaal geldende richtlijnen gehanteerd ten aanzien van de personele capaciteit van dergelijke instellingen (zie Blankenstein, 11). De arbeidsvoorwaarden van de medewerkers ervan worden op landelijk niveau bepaald. De extramurale voor eigen rekening werkende beroepsbeoefenaren kennen een vrij vestigingsbeleid. Alleen voor apothekers geldt, dat ze zich pas kunnen vestigen na toestemming van de eigen professionele organisatie. Het investeringsbeleid wordt in principe ontwikkeld door de individuele werkeenheden zelf. Voor het uitvoeren van dit beleid is dan toestemming nodig van een externe instantie. Voor investeringen in intramurale instellingen boven een bedrag van $f 500.000$ is krachtens de Wet Ziekenhuisvoorzieningen toestemming nodig van het Ministerie van V\& M.

Het Ministerie beslist over deze toestemming op advies van het College voor Ziekenhuisvoorzieningen. Het doet dit, nadat het over het advies van dit college de mening heeft gevraagd van de betrokken provinciale overheid. Er bestaan uitvoerige procedure-regelingen voor de toestemmingsverlening (zie $C V Z, 36$ en 34).

Voor de investeringen in apparatuur bepaalt het ziekenhuisbestuur zelfstandig het beleid. De enige uitzonderingen hierop betreffen investeringen in zeer dure apparatuur, zoals voor open hartchirurgie en nierdialyse (zie ook hierboven). In deze gevallen stelt het $\mathrm{COZ}$ een maximum aan de afschrijvingen en de rente. In de overige situaties is de randvoorwaarde dat de afschrijvingen en rentebetaling voor de apparatuur moeten passen binnen de ziekenhuisbegroting. Het $\mathrm{COZ}$ ziet hierbij alleen toe, of de juiste afschrijvings- en rentepercentages worden gehanteerd. Voor de extramurale instellingen geldt meestal dat toestemming om te investeren nodig is van de geldgever. Deze toestemming is meestal gekoppeld aan de toestemming om de gevolgen van de investeringen in de exploitatierekening te mogen doorberekenen.

Bij alle werkeenheden geldt, dat de geldgever - en bij ziekenhuizen het Ministerie niet in staat is het doen van investeringen of het verhuizen naar een ander gebouw te verplichten. Wel heeft het Ministerie door een recente wijziging in de Wet Ziekenhuisvoorzieningen (108) de bevoegdheid om een ziekenhuis te sluiten.

In 1977 heeft de regering het Ontwerp Wet Voorzieningen Gezondheidszorg (106) uitgebracht. Behalve de regelingen ten aanzien van het opstellen van provinciale aktiviteitenplannen (zie hieronder), bevat dit wetsontwerp ook een verandering voor het investeringsbeleid van de werkeenheden en van de kwaliteitsbeoordeling. Voor de intramurale instellingen geldt, dat het provinciale bestuur een verklaring moet afgeven, dat de investering past in het provinciale plan. Daarnaast blijft het advies nodig van het College voor Ziekenhuisvoorzieningen en de toestemming van het Ministerie. Voor de extramurale instellingen geldt, dat voortaan dezelfde procedures als voor de ziekenhuizen moeten worden doorlopen. Het adviesorgaan voor het Ministerie wordt dan - volgens het ontwerp - omgedoopt in College voor Gezondheidszorg Voorzieningen.

De laatste kategorie beslissingen in deze paragraaf betreft de samenwerking tussen werkeenheden in dezelfde regio. De funktiepakketten van werkeenheden in een regio worden afgebakend door overleg tussen funktionarissen van de verschillende werkeenheden. Ditzelfde geldt ook voor gezamenlijk op te zetten aktiviteiten. Hiertoe bestaan min of meer gestruktureerde overlegorganen tussen gelijksoortige werkeenheden in eenzelfde regio. Deze hebben meestal geen regelende bevoegdheden en deelname aan het overleg is niet verplicht. Als voorbeeld van een gebied met dergelijke gestruktureerde overlegorganen is de gemeente Utrecht te noemen. In de gemeente bestaan in 1979 een Stichting Samenwerkende Utrechtse Ziekenhuizen, een 
plaatselijke huisartsenvereniging, een Utrechtse Stichting voor Ambulante Geestelijke Gezondheidszorg. Daarnaast bestaan in deze stad ad hoc projectorganisaties ten behoeve van het beleid over geslachtsziektenbestrijding, opname van verpleeghuizen en traumatologie. Indien werkeenheden een overeenkomstig aktiviteitenpakket aanbieden zien we ook fusie optreden: in de gemeente Utrecht is sinds januari 1977 de Kruisvereniging voor de stad Utrecht werkzaam. Deze is ontstaan uit drie katholieke, twee protestants-christelijke en één algemene kruisvereniging.

Het beleid van de rijks- en lokale overheden is erop gericht de samenwerking tussen werkeenheden te stimuleren. De instrumenten hierbij zijn voor het rijk het koppelen van voorwaarden aan het beschikbaarstellen van financiële middelen. Lokale overheden financieren soms rechtstreeks samenwerkingsorganen. Door provinciebesturen worden reeds sinds 1956 Provinciale Raden voor de Volksgezondheid gefinancierd. Deze raden vormen een overlegorgaan tussen de provinciale overheid en de instellingen van het particuliere initiatief met als belangrijkste taken (Gezondheidswet 1956, art. 47, 44):

a. het stimuleren van de gezondheidszorg binnen de provincie.

b. het bevorderen van de coördinatie van alle werkzaamheden, welke op het gebied van de volksgezondheid binnen de provincie worden verricht.

c. het uitbrengen van adviezen, onder meer omtrent de verdeling van rijkssubsidies en het bevorderen van het ter beschikking stellen van gelden en andere middelen ten behoeve van de gezondheidszorg.

Voor enkele grote steden (Rotterdam, Den Haag) en gewesten (Zuid-Limburg, Kennemerland, Agglomeratie Eindhoven) zijn in de laatste jaren overlegorganen met overeenkomstige taken in het leven geroepen. Deze worden gefinancierd door de gemeente casu quo het gewest, dan wel door het Ministerie van V \& M, indien het gewest een proefregio (zie paragraaf 1.1. vormt).

Ten aanzien van de samenwerking t!ıssen ziekenhuizen liggen COZ-richtlijnen bij het Ministerie van V \& M ter goedkeuring, waarbij onder bepaalde voorwaarden aan een regionaal samenwerkingsorgaan financiële middelen ter beschikking worden gesteld uit de verpleegprijzen. Anderzijds wordt gewerkt aan richtlijnen om bepaalde kostensoorten slechts dan goed te keuren, indien wordt samengewerkt (Groot, 51). Voor de instellingen van de geestelijke gezondheidszorg wordt door het Ministerie van V \& M gestreefd naar de vorming van Regionale Instituten voor de Geestelijke Gezondheidszorg (RIGG's), met als taak de samenhang tussen deze instellingen te bevorderen. Als voorloper op deze - nog niet bestaande - RIGG's, worden of zijn thans in verschillende regio's, onder andere de Oostelijke Mijnstreek, RIAGG's geyormd (RIAGG: Regionaal Instituut voor de Ambulante Geestelijke Gezondheidszorg, zie uitvoerig $N V A G G, 74$ ).

Om de samenwerking in de eerstelijnsgezondheidszorg te stimuleren worden en zijn in verschillende regio's aparte overlegorganen gevormd. Te wijzen is op de vorming van een "Provinciaal platform" in verschillende provincies en op bijvoorbeeld de SOSEL - Stichting ter bevordering van de Ontwikkeling van de Samenwerkingsverbanden in de Eerstelijnsgezondheidszorg - in de gemeente Amsterdam.

Door wetgeving wil de rijksoverheid het vaststellen van het funktiepakket van een werkeenheid en de besluitvorming over de samenwerking tussen werkeenheden meer dan tot nu toe leggen bij de lokale overheid (provincies en grote steden). Hiertoe heeft de regering in het ontwerp van Wet Voorzieningen Gezondheidszorg (106) een aantal artikelen opgenomen, die de planning en de onderlinge afstemming van werkeenheden in eenzelfde regio moeten regelen.

Artikelen 7 tot en met 9 van het wetsontwerp geven aan, dat op basis van richtlijnen van het Ministerie van $V \& M$ provincies en daartoe aangewezen gemeenten, 
plannen moeten opstellen voor door het Ministerie aangewezen kategorieën van voorzieningen (instellingen en voor eigen rekening werkende beroepsbeoefenaren) voor gezondheidszorg. In deze plannen worden "de behoefte aan die voorzieningen in het betrokken gebied neergelegd en wordt omschreven welke aanvullingen of veranderingen in het reeds aanwezige bestel in de jaren waarop het plan betrekking heeft nodig zijn om op een doelmatige wijze in die behoefte te voorzien. Tevens wordt zoveel mogelijk aangegeven welk beslag het plan legt op personele, materiële en financiële middelen" (Wet Voorzieningen Gezondheidszorg, 106, artikel 7).

Deze plannen moeten worden goedgekeurd door het Ministerie van V \& $M$. Is het plan goedgekeurd, dan behoeft de instelling een "erkenning" om in aanmerking te komen voor vergoeding van de kosten krachtens de Ziekenfondswet of de AWBZ. Gedeputeerde Staten casu quo burgemeester en wethouders beslissen over deze erkenning, indien deze betrekking heeft op een in het provinciaal casu quo gemeentelijk plan voorkomende voorziening (art. 18). Een erkenning kan worden geweigerd, indien de voorziening niet past in het plan, dan wel niet voldoet aan een aantal kwaliteitseisen (art. 19). Om de samenhang tussen de voorzieningen in de regio te bevorderen kunnen de Provinciale Staten casu quo gemeenteraden verordeningen vaststellen. De colleges van Gedeputeerde Staten casu quo van burgemeester en wethouders kunnen hierbij aanwijzingen geven, op welke wijze de samenhang in het funktioneren dient te worden gerealiseerd (art. 36).

Voor sommige soorten zorg wordt reeds via andere vormen van wetgeving op deze wet vooruitgelopen. In 1971 is de Wet Ambulancevervoer (102) aangenomen, die de taakafbakening tussen ambulancediensten moet regelen. $O \mathrm{p}$ basis van deze wet worden thans in de verschillende provincies pogingen gedaan tot een dergelijke afbakening.

\subsubsection{Het financieringsstelsel}

Van de Nederlandse bevolking is $70 \%$ verzekerd bij de ziekenfondsen en $30 \%$ bij particuliere maatschappijen. De eerstgenoemden worden bestuurd door organisaties van werkgevers, werknemers of artsen. Ze hebben een publiekrechtelijk karakter. Loontrekkenden met een inkomen beneden de ziekenfondsgrens (in 1978: $f$ 36.200) zijn wettelijk verplicht zich bij een ziekenfonds aan te sluiten. Bejaarden en zelfstandigen beneden bepaalde inkomensgrenzen kunnen zich vrijwillig bij een ziekenfonds verzekeren. De particulier verzekerden kennen veelal een vorm van eigen risico, meestal voor huisartsen- en tandartsenhulp en soms voor een deel voor de specialistische behandeling.

Het Algemene Fonds Bizzondere Ziektekosten (AFBZ) is krachtens de Algemene Wet Bijzondere Ziektekosten (AWBZ) in 1968 ingesteld. Oorspronkelijk was de AWBZ bedoeld om de kosten te dekken voor dure behandelingen. Het verblijf in verpleeghuizen en zwakzinnigeninrichtingen wordt vanaf de eerste dag en van andere intramurale instellingen vanaf de $366^{\mathrm{e}}$ dag betaald uit het AFBZ. Sinds kort worden ook enige minder "dure" voorzieningen uit het AFBZ gefinancierd, zoals de Sociaal-Psychiatrische Diensten en bevolkingsonderzoek. In de nabije toekomst moeten ook gezondheidscentra hieruit ondersteund worden (Het beleid terzake van de gezondheidszorg met het oog op de kostenontwikkeling, 56). De werkeenheden verwerven hun inkomsten via een systeem met tarieven of met budgetfinanciering, dan wel via een mengvorm van beide. De intramurale instellingen - op de gezinsvervangende tehuizen met een budgetfinanciering na - kennen een tariefstelsel. Als belangrijkste tariefeenheden worden onderscheiden de verpleegdag, het consult en de verrichting. Aangezien de medische specialist de aktiviteitenomvang bepaalt per patiënt, is de intramurale instelling voor haar inkomen afhankelijk van de aktiviteiten van de 
specialist. Daarnaast zijn haar inkomsten afhankelijk van de hoogte van het tarief. De kosten waarop de tarieven worden gebaseerd, moeten worden goedgekeurd door het Centraal Orgaan Ziekenhuistarieven (COZ) voor zover deze particuliere patiënten betreffen. Voor de fondspatiënten beslist de Ziekenfondsraad na advisering door het $\mathrm{COZ}$. De tarieven komen tot stand op basis van landelijke normen voor de kosten. Een uitgangspunt hierbij is, dat de instellingen geen winst of verlies mogen maken. Het beleid van het $\mathrm{COZ}$ beoogt de intramurale instellingen een vergoeding te geven voor de werkelijke kosten, voor zover deze de toets van een redelijke kritiek kunnen doorstaan. Om de kosten van de ziekenhuizen te kunnen beoordelen is in de loop der jaren een stelsel van richtlijnen ontwikkeld. Dit stelsel wordt regelmatig aangepast in het licht van zich wijzigende arbeidsvoorwaarden, prijswijzigingen van goederen en diensten en van veranderingen in het aktiviteitenpakket. Een deel van de normen van het $\mathrm{COZ}$ is van formele aard. Dit deel betreft de berekeningswijze van afschrijvingen en rente en de bepaling van de sleutels, op basis waarvan klassetarieven worden berekend. Deels zijn ze ook van materiële aard. Te denken is dan aan de personeelsbezetting op verschillende afdelingen, de kosten voor onderhoud en de voeding (zie uitvoerig: $C O Z, 26$ en 27, Groot, 53).

De medisch specialist in het ziekenhuis kent een eigen tariefstelsel. Voor fondsverzekerden bestaat het stelsel van verwijskaart en herhalingskaarten. Voor particulierverzekerden wordt de specialist per consult en per verrichting betaald. De particuliere tarieven zijn voor dezelfde verrichting hoger dan de fondstarieven. Circa $70 \%$ van het tarief bestaat uit een honorarium en $30 \%$ uit een kostenvergoeding. De instellingen en voor eigen rekening werkende beroepsbeoefenaren in de extramurale sektor kennen vele, onderling verschillende, betaalsystemen. De huisarts kent voor de fondspatiënt een honorering per abonnement en voor de particuliere patiënten een tariefsysteem. De overige, extramurale, voor eigen rekening werkende beroepsbeoefenaren zoals fysiotherapeuten en vroedvrouwen ontvangen hun inkomsten per verrichting. Budgetfinanciering komt voor bij kruisverenigingen, schoolartsendiensten, ambulante geestelijke gezondheidszorg, dagverblijven voor gehandicapten, een aantal gezondheidscentra en bij bedrijfsgeneeskundige diensten. Bij deze budgetfinanciering is meestal sprake van subsidiëring door meer dan één overheids- of verzekeringsinstantie. Bedrijfsgeneeskundige diensten worden op basis van budgetten gefinancierd door de bedrijven of de instellingen, waarvoor ze funktioneren.

Soms is de budgetfinanciering gedeeltelijk en vindt er ook een geringe betaling per verrichting plaats, bijvoorbeeld bij de uitleen van hulpmiddelen door de kruisvereniging (zie Blankenstijn, 11, Damen en Nuyens, 37, NVAGG, 74 en Van der Grinten, 48).

Voorzover bij extramurale instellingen en voor eigen rekening werkende beroepsbeoefenaren sprake is van een tariefsysteem, komen de tarieven tot stand in een onderhandelingsproces tussen de zorgverleners en de verzekeringsinstellingen. Het eenmaal tot stand gekomen tarief behoeft goedkeuring van het Ministerie van Economische Zaken.

Naast de wijze waarop financiële middelen aan werkeenheden ter beschikking worden gesteld, is ook van belang de financieringsbron. In tabel 5.3.2. worden vijf financieringsbronnen onderscheiden. Deze worden bekeken voor de jaren 1953 en 1974. De aandelen in de financiering van het rijk en de gezinshuishoudingen stijgen van $9,5 \%$ en $76,1 \%$ in 1953 naar $12,9 \%$ en $83,4 \%$ in 1974 .

De aandelen van de overige financieringsbronnen nemen over deze periode af. De uitgaven in 1974 van het rijk ( 1,9 mld. gulden) betreffen overdrachten aan de sociale verzekeringsfondsen, AWBZ en Ziekenfonds (1,2 mld. gulden), bijdrage exploitatie van Academische Ziekenhuizen (290 mln. gulden) en de subsidiëring van kruisvereni- 
$1953 \quad 1974$

\begin{tabular}{lrr} 
Totaal in mln. gld. & 770,0 & $14.771,3$ \\
Rijk & $9,5 \%$ & $12,9 \%$ \\
Provincie & $1,5 \%$ & $0,1 \%$ \\
Gemeenten & $10,6 \%$ & $2,0 \%$ \\
Gezinshuishoudingen & $76,1 \%$ & $83,4 \%$ \\
Bedrijven & $2,3 \%$ & $1,6 \%$ \\
\hline & $100 \%$ & $100 \%$ \\
\hline
\end{tabular}

Bron: CBS

gingen en een aantal instellingen voor ambulante geestelijke gezondheidszorg $(0,5$ mld. gulden). De uitgaven van de provincies in 1974 (totaal 17 mln. gulden) betreffen een aantal extramurale instellingen $(12 \mathrm{mln}$. gulden) en beheers- en beleidskosten van de provincies zelf ( 5 min. gulden).

De gemeenten financieren in 1974 voor een totaal bedrag van $497 \mathrm{mln}$. gulden achtereenvolgens intramurale instellingen (hoofdzakelijk gemeenteziekenhuizen $98 \mathrm{mln}$. gulden), een aantal extramurale instellingen (vooral GG en GD's, $226 \mathrm{mln}$. gulden) en de instellingen voor gezondheidsbescherming (150 min. gulden). Omdat de gemeenten zelf uit andere bronnen financiële middelen verwerven komt per saldo 287 $\mathrm{mln}$. gulden ten hunne laste.

Het aandeel van de gemeenten in de financiering van de gezondheidszorg neemt van $10,6 \%$ in 1953 af tot $2,0 \%$ in 1974 . Als een van de verklaringen hiervoor komt de invoering in 1968 van de AWBZ in aanmerking, waardoor de gemeenten minder geld via de Bijstandswet aan gezondheidsvoorzieningen hoeven te betalen. Bij de daling van het gemeentelijke aandeel kan verder ook het feit een rol spelen, dat gemeenteziekenhuizen steeds meer self-supporting worden.

$V$ an de gezinshuishoudingen gaat in 1974 van het totaal bedrag van 12,3 mld. gulden het grootste deel via verzekeringsinstellingen naar de instellingen yoor gezondheidszorg. Deze verzekeringsinstellingen zijn in te delen in ziekenfondsen $(6,1 \mathrm{mld}$. gulden), het Algemene Fonds Bijzondere Ziektekosten ( 2,1 mld. gulden) en de particuliere verzekeringsmaatschappijen. Een bedrag van 3,7 mld. gulden wordt in 1974 door particuliere patiënten betaald. Er zijn geen statistische gegevens beschikbaar betreffende de verdeling hiervan over betalingen door de patiënt zelf in verband met het eigen risico en betalingen door de particuliere verzekeringsmaatschappijen.

De bedrijven betaalden in $1974233 \mathrm{mln}$. gulden, vooral voor bedrijfsgeneeskundige zorg $(80 \mathrm{mln}$. gulden) en voor de bescherming van voedsel en drinkwater (130 mln. gulden).

Uit boven gegeven beschrijving blijkt dat in de Nederlandse gezondheidszorg verschillende vormen van tariefsystemen en budgetfinanciering en verschillende financieringsbronnen naast elkaar voorkomen. Om de financiering van de gezondheidszorg. te stroomlijnen heeft het kabinet-Den Uyl een aantal jaren gewerkt aan het ontwerp van Wet Verzekeringen Gezondheidszorg (103). Dit wetsontwerp, waarvan het concept in september 1975 uitlekte en openbaar werd, beoogde de invoering van één volksverzekering tegen ziektekosten, hetgeen neerkomt op een samenvoeging van de particuliere en ziekenfondsverzekeringsinstellingen. Het wetsontwerp is 
echter nooit officieel bij de Tweede Kamer ingediend, omdat de uitvoering ervan een te grote verhoging van de verzekeringspremie voor bepaalde groepen van particuliere verzekerden zou betekenen.

In 1977 diende de regering een ontwerp Wet Tarieven Gezondheidszorg (105) in bij de Tweede Kamer. Deze wet moet ertoe leiden dat de tarieven van alle gezondheidszorginstellingen en de honoraria van voor eigen rekening werkende beroepsbeoefenaren door hetzelfde orgaan worden beoordeeld. Dit orgaan, het Centraal Orgaan Gezondheidszorg Tarieven (COGT), zal dan het $\mathrm{COZ}$ moeten vervangen en opvolgen. Tevens moeten dan de verschillen in tarieven voor fonds- en particulier verzekerden mettertijd verdwijnen.

\subsection{DOELSTELLINGEN GEZONDHEIDSZORG}

\subsubsection{Niveau en kwaliteit handhaven}

Sinds 1950 is de aktiviteitenomvang en de capaciteit van de Nederlandse gezondheidszorg toegenomen. Waren er in 194775.680 personen werkzaam in de gezondheidszorg (7,8 per 1000 inwoners) in 1976 bedroeg dit aantal 245.000 (17,8 per 1000 inwoners). Deze groei hangt samen met een aktiviteitentoename van vooral de intramurale instellingen. Het aantal opnames in algemene ziekenhuizen is in 1975 meer dan het dubbele van dat in 1950. Ook de overige instellingen kennen over de afgelopen tien à twintig jaar een groei. In 1975 staan aan de Nederlandse bevolking ruim 166.000 bedden ter beschikking in intramurale instellingen, ofwel 12,2 per 1000 inwoners (zie tabel 5.4.1.).

Een groot deel hiervan staat in algemene ziekenhuizen (5,5 per 1000 inwoners). De overige instellingen zijn elk goed voor twee à drie bedden per 1000 inwoners.

Een beeld van de gemiddelde omvang van de intramurale instellingen geeft onderstaand overzicht.

\begin{tabular}{lrl}
\hline & aantal & gemiddelde omvang in bedden \\
\hline algemene ziekenhuizen & 248 & 300 \\
psychiatrische ziekenhuizen & 72 & 363 \\
verpleeghuizen & 298 & 136 \\
zwakzinnigeninrichtingen & 128 & 204 \\
\hline
\end{tabular}

Bron: $C B S(22)$

In Nederland heeft zich een proces van schaalvergroting voorgedaan ten aanzien van algemene ziekenhuizen. Een aanduiding hiervoor geeft de toename van de gemiddelde omvang van deze instellingen van 173 bedden in 1950 naar 300 bedden in 1975 . Het aantal polikliniekbezoeken aan algemene ziekenhuizen bedraagt in 1975 bijna 15 miljoen, per Nederlander gemiddeld 1,07 bezoek per jaar. Het aantal consultaties bij huisartsen bedraagt in de jaren zeventig volgens verschillende onderzoeken vier per inwoner (Damen en Nuyens, 37). Waarschijnlijk was dit cijfer in vroegere jaren hoger. Een onderzoek in 1957-1958 in Zutphen, geciteerd in de Volksgezondheidsnota 1966 (96) komt op zes consulten per inwoner. Het aantal artsen is in de afgelopen jaren bijna verdrievoudigd. De groei heeft vooral plaatsgevonden bij de medisch specialisten. Het aantal huisartsen is sinds 1947 met 1500 toegenomen, maar per 1000 inwoners gelijk gebleven. De overige beroepsbeoefenaren, tandartsen, gediplo- 
Tabel 5.4.1. Aktiviteiten en voorzieningen van de Nederlandse gezondheidszorg $1950-1975$

absolute aantallen

$1950 \quad 1975$

aantallen per

1000 in woners

$1950 \quad 1975$

Aantal consultaties bij huisartsen

Aantal polikliniekbezoeken in alg. ziekenhuizen

Aantal opnames $(x 1000)$ in

$-$

$-$

5

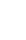
alg. ziekenhuizen

- psychiatrische ziekenhuizen

- verpleeghuizen voor somatisch zieken

- verpleeghuizen voor demente bejaarden

- zwakzinnigeninrichtingen

Gemiddelde ligduur in alg. ziekenhuizen in dagen

Gemiddelde bezettingsgraad in:

- algemene ziekenhuizen

- psychiatrische ziekenhuizen

- somatische verpleeghuizen

- verpleeghuizen voor geestelijk gestoorde bejaarden

- zwakzinnigeninrichtingen

Aantal arbeidskrachten (x 1000)

Aantal artsen

Aantal huisartsen

Aantal specialisten

Aantal tandartsen

Aantal gedipl. verpleegkundigen

Aantal wijkverpleegkundigen

Aantal apothekers

Aantal bedden $(x$ 1000) in:

algemene ziekenhuizen

psychiatrische ziekenhuizen

somatische verpleeghuizen

verpleeghuizen voor demente

bejaarden

zwakzinnigeninrichtingen

totale intramurale zorg ${ }^{9}$
507,9

$8,7^{2}$

$0,2^{2}$

21,7

$21,7 \quad 16,1$

$75.680^{2}$

$7.725^{3}$

$3.482^{3}$

$2.041^{3}$

$1.553^{3}$

$28.718^{8}$

$3.051^{5}$

$813^{6}$

$\begin{array}{rr}35,9^{6} & 74,6 \\ 124,5^{7} & 26,3 \\ 6,9^{8} & 27,0 \\ & \\ 1,3^{8} & 13,1 \\ 3,6^{7} & 25,9 \\ 71,7 & 166,9\end{array}$

1442,8

23,3

34,0

3,3

$85 \%$

$93 \%$

$95 \%$

$98 \%$

21.892

4.937

7.223

4.462

3.721

1.197 ca. $58 \mathrm{~min}$.

$14,9 \mathrm{mln}$.

$40.000^{11}$

7,8

$0,8^{3}$

0,36

$0,20^{3}$

$0,16^{3}$

$2,8^{8}$

$0,20^{5}$

0,08

$17,8^{10}$

1,6

0,36

0,53

0,32

$2,9^{11}$

0,27

0,09

$3,6^{5} \quad 5,5$

$2,5^{7} \quad 1,9$

$0,6^{8} \quad 2,0$

$0,1^{8}$

$0,4^{7}$

0,9

1,9

$7,0 \quad 12,2$

Bron: Belleman (7), CBS (20 en 22), NZI (75).

${ }^{1}$ Exclusief militaire hospitalen en sanatoria.

21949.

${ }^{3} 1947$.

5 1951, exclusief wijkverpleegkundigen Oranje-Groene Kruis.

6 1951.

7 Bezette bedden in 1949.

- Bron: Volksgezondheidsnota 1966 (96).

- Som van de instellingen sub 22 tot en met 26.

10 1976, bron: Ministerie van V \& M (69).

1 Grove schatting CBS. 
meerd verpleegkundigen, wijkverpleegkundigen en apothekers namen alle zowel in totaal als per 1000 inwoners toe.

In Nederland wordt getracht het niveau van de intramurale voorzieningen terug te brengen en dat van de extramurale voorzieningen te stimuleren. Het Ministerie van V \& $M$ streeft naar het terugbrengen van het tegenwoordige aantal algemene ziekenhuisbedden per 1000 inwoners van 5,6 naar 5,0 in 1980 als eerste fase om te komen tot vier bedden op langere termijn. Er wordt verwacht, dat het aantal medisch specialisten in $198224 \%$ hoger zal zijn dan in 1977 (9565 versus 7710). Voor huisartsen bedraagt dit groeipercentage $43 \%$ ( 7050 versus 4926 ) (Ministerie van $V \& M, 69$ en Belleman, 7).

Over de toegankelijkheid van de gezondheidszorg is op te merken, dat in 1975 de praktijkomvang van de huisarts gemiddeld 2800 patiënten bedroeg. Wachtlijsten worden in Nederland niet geregistreerd. Vanuit het Instituut voor Ziekenhuiswetenschappen bestaat op grond van haar kontakten met instellingen de indruk, dat voor acute zorgverlening bij geen van de voorzieningen wachtlijsten bestaan. Bij de huisarts geldt dit veelal ook voor de niet-acute zorgverlening. Bij het maken van een afspraak voor een niet-dringend specialistisch consult in de polikliniek lijken wachttijden van twee weken normaal. Niet-acute opnamen in een ziekenhuis kunnen een wachttijd opleveren van enige weken. Voor top-klinische funkties zijn de wachttijden langer. In verband met de lengte hiervan zijn voor open-hart-chirurgie luchtbruggen geopend naar Houston (USA), Genève en London. Tenslotte is te vermelden dat soms enige maanden voorbij gaan voordat plaatsing in een verpleeghuis mogelijk is.

Als oorzaken voor de aktiviteitenontwikkeling sinds 1950 zijn te noemen (zie ook: Groot, 52):

1. de groei van het BNP vanaf 1950 (zie par. 5.1.1.) waardoor meer aktiviteiten gerealiseerd konden worden.

2. de groei van het dekkingspakket van de sociale verzekeringen, waardoor meer voorzieningen voor grotere delen van de bevolking bereikbaar werden. In wezen hangt deze factor samen met sub 1.

3. de vergrijzing van de bevolking (zie par. 5.1.1.).

4. de ontwikkeling van de medische wetenschap, waardoor meer mogelijkheden tot behandeling gecreëerd werden. Bovendien blijven hierdoor meer mensen in leven, met na de behandeling een grote, continue vraag om zorg in verpleeghuizen, revalidatie-inrichtingen en om nazorg in de eigenlijke woonomgeving.

5. de invloed van het financieringsstelsel. Hierop wordt hieronder nader ingegaan.

De financiering via sociale verzekeringen op basis van een tariefstelsel heeft onmiskenbaar de ontwikkeling van de Nederlandse gezondheidszorg sterk bevorderd. Door de financiering uit vooral de sociale verzekeringen bleef de gezondheidszorg grotendeels buiten de prioriteitsstelling en verantwoording van de rijksoverheid. Hierdoor kon de gezondheidszorg zich relatief autonoom en vrij ontwikkelen. Daar komt bovenop de financiering per verrichting, waardoor elke extra-aktiviteit zichzelf betaalt. Hierbij geldt dat de marginale opbrengsten hoger zijn dan de marginale kosten voor een intramurale instelling met overwegend vaste kosten. Dit houdt een extra stimulans in tot meer verrichtingen. Harde bewijzen voor deze invloed zijn moeilijk te geven. De stelling wordt ondersteund door uitspraken van de volgende leidinggevende personen in de gezondheidszorg.

Veldkamp - oud-minister van Volksgezondheid - stelt zich in 1968 de vraag of de gezondheidszorg uit de belastingen moet worden gefinancierd. Hij antwoordt zichzelf dan: "Ik meen dat deze vraag ontkennend moet worden beantwoord. In de eerste plaats geloof ik niet, dat ons volksbestel ongunstig funktioneert in vergelijking 
tot dat van andere landen en ook niet ten opzichte van dat van landen met een nationale gezondheidsdienst. In de tweede plaats wordt het volksgezondheidsbeleid dan veel meer gebracht in de budgettaire prioriteitenafweging, met alle gevaren van dien" (Veldkamp, 94).

In 1971 stelt $d r$. H. Festen voorzitter van de Centrale Raad voor de Volksgezondheid: "Mijn eerste en voornaamste argument om bij een collectieve financiering de voorkeur te geven aan de methode van de sociale verzekering boven die van financiering uit de algemene middelen, is dat bij het bepalen van prioriteiten in de besteding der belastinggelden (waaraan de overheid niet kàn ontkomen), de ontwikkeling van de gezondheidszorg gevaar loopt door aanspraken van de zijde van onderwijs, defensie enz."' (Festen, 43).

Anbeek, voorzitter van de Vereniging van Nederlandse Ziekenfondsen, zegt het in 1973 anders: "Door het systeem van financieren heeft de ene sector veel meer mogelijkheden gekregen dan de andere. Die sectoren die gefinancierd worden via de premie, geheven op grond van de sociale verzekeringswetten, waarbij de hulp in natura wordt gegarandeerd, hebben de neiging ongeremd uit te groeien (...). De organisaties en instellingen, die gesubsidieerd worden via de rijksbegroting hebben deze subsidies in veel mindere mate zien stijgen."

Het financieringsstelsel heeft niet alleen de ontwikkeling van de Nederlandse gezondheidszorg als totaal beinvloed. Ook is te wijzen op de invloed ervan op de verschillen in zorgverlening aan particulier- en fondsverzekerden. Voor een beperkte steekproef (van circa 8500 patiënten) toont Rutten (84) in zijn dissertatie aan, dat de kans op een verwijzing naar de specialist voor een particulier verzekerde $26 \%$ lager is dan voor een fondsverzekerde. Dit percentage komt naar voren, nadat de invloed op het aantal verwijzingen van een aantal andere faktoren met behulp van een econometrische analyse is uitgeschakeld. Deze andere faktoren betreffen de leeftijd, het geslacht, de sociale klasse, de morbiditeit en de huisvesting van de verzekerden. Als verklaring voor het verschil van $26 \%$ wijst Rutten op het bestaan van verschillen in financiële prikkels, die het abonnementstarief voor fondsverzekerden en het verrichtingstarief voor particuliere patiënten veroorzaken op het gedrag van huisartsen.

\subsubsection{Afremming kostengroei}

In tabel 5.4.2. wordt de ontwikkeling van de kosten van de Nederlandse gezondheidszorg aangegeven vanaf 1953. De kosten in 1976 zijn 24,2 maal zo hoog als in 1953. Het aandeel in het BNP is in 19762,6 maal zo hoog als in 1953. Het prijsin-

Tabel 5.4.2. Ontwikkeling kosten Nederlandse gezondheidszorg 1953 - 1975

\begin{tabular}{lrlllll}
\hline & $\begin{array}{l}\text { mld. } \\
\text { gld. }\end{array}$ & $\begin{array}{l}\text { \% van } \\
\text { BNP }\end{array}$ & $\begin{array}{l}\text { indexcijfer } \\
1970=100\end{array}$ & $\begin{array}{l}\text { waarde- } \\
\text { prijs }\end{array}$ & $\begin{array}{l}\text { hoeveel- } \\
\text { heid }\end{array}$ & $\begin{array}{l}\text { hoeveelheid } \\
\text { per inwoner }\end{array}$ \\
\hline 1953 & 0,8 & 3,2 & 11 & 21 & 52 & 65 \\
1958 & 1,4 & 3,8 & 19 & 20 & 63 & 73 \\
1963 & 2,3 & 4,3 & 31 & 43 & 72 & 78 \\
1968 & 4,8 & 5,3 & 66 & 78 & 85 & 87 \\
1970 & 7,3 & 6,3 & 100 & 100 & 100 & 100 \\
1974 & 14,8 & 7,9 & 204 & 170 & 120 & 115 \\
1976 & 19,4 & 8,2 & 266 & - & - & - \\
\hline
\end{tabular}

Bron: $C B S$ (18) en Ministerie van $V \& M(69)$. 
dexcijfer voor de gezondheidszorg is in 19748,1 maal zo hoog als in 1953. De volume ontwikkeling houdt in, dat in 1974 zowel in totaal als per inwoner ongeveer tweemaal zoveel zorg wordt verleend als in 1953.

Sinds het eind van de jaren zestig verschijnen publicaties waarin de stijging van de kosten van de gezondheidszorg problematisch worden genoemd. Met name de zegswijze: "De kosten rijzen de pan uit", wordt regelmatig genoemd (De Pous, 81). Sinds het begin van de jaren zeventig wordt de afremming van de kostengroei meer en meer een expliciet beleidsuitgangspunt (Beleidsvoornemens kostenbeheersing, 6, $\mathrm{COZ}, 27$, Ziekenfondsraad, 115 en 116). Verschillende onderzoeken naar de beheersbaarheid van de kosten worden verricht (Van Aert, 2, Van Aert en Van Montfort, 3, Blox, 12 en Rutten, 85).

De instrumenten die het Ministerie ter beschikking staan om de kostenontwikkeling af te remmen, zijn de volgende:

1. een restrictief beleid ten aanzien van de verhoging van tarieven van zowel de intramurale instellingen als de artsen.

2. een restrictief beleid ten aanzien van het verlenen van vergunningen voor nieuwbouw van intramurale instellingen.

3. een afremming van de groei van de premiedruk.

Ze komen in de volgende paragrafen aan de orde.

\subsubsection{Restrictief vergunningenbeleid vanaf 1973}

Zoals in paragraaf 5.3.3. aangegeven, is voor nieuwbouw van ziekenhuizen een advies van het College voor Ziekenhuisvoorzieningen en een vergunning van het Ministerie van V \& $M$ nodig.

Vanwege de verminderde nationale economische groei is in 1973 door de toenmalige Minister van Volksgezondheid, Stuyt, een "selectief investeringsbeleid" ingesteld. Dit beleid hield een maximum in voor nieuwe investeringen. Alleen de lopende "pijplijn" investeringen konden worden afgerond. In 1975 is dit beleid vervangen door een beleid met een bouwplafond voor de intramurale gezondheidszorg. Voor 1975 gold een bouwprogramma van $f 500 \mathrm{mln}$. in prijzen van 1975 . Het bouwvolume werd niet onderverdeeld naar voorzieningensector. Hoewel derhalve geen prioriteitenstelling in geld werd uitgedrukt, was de opzet wel dat een verschillend accent gelegd werd op de verschillende sectoren. Een voorkeur ging uit naar de psychiatrische ziekenhuizen en de zwakzinnigeninnichtingen (College voor Ziekenhuisvoorzieningen, 36, jaarverslag 1975, p. 48).

Voor de jaren 1976 - 1980 is het beleid erop gericht dit jaarlijkse bouwplafond met een prijsindexatie te handhaven. Indien het bouwplafond dreigt te worden overschreden en niet alle bouwplannen kunnen worden gehonoreerd, blijft circa 10\% (55 min. gulden) van het bouwplafond gereserveerd voor nieuwbouw van psychiatrische ziekenhuizen.*

Voorjaar 1978 is voor het eerst in één keer een totaallijst gepubliceerd van instellingen, die voor de besteding van dit investeringsbudget in 1978 en 1979 in aanmerking komen.

Voor de prioriteitenstelling binnen de investeringsruimte naar regio zijn geen duidelijke kriteria ontwikkeld. Aanvankelijk werden de bouwplannen door de provinciale besturen voorzien van een urgentie-aanduiding. In verband met het bouwplafond echter konden ook niet meer alle als zeer urgent gekwalificeerde plannen aanstonds worden gehonoreerd. Daarom heeft het CVZ - in overleg met het departement - in

* Specifiek voor deze sektor heeft in 1979 een toevoeging aan het bouwplafond van $80 \mathrm{mln}$. gulden plaatsgevonden. 
1976 besloten de adviezen niet langer te voorzien van urgentiekwalificaties. Sinds 1976 worden de provinciale besturen betrokken bij de prioriteitenstelling, zonder dat evenwel op basis van een provinciaal budget werd gewerkt (CVZ, jaarverslag 1975 p. 67, zie uitvoerig: Boot \& Zuidberg, 14).

\subsubsection{Restrictief tarievenbeleid}

Sinds 1974 wordt het materiële beleid ten aanzien van tarieven van intramurale en andere instellingen gekenmerkt door een strenge terughoudendheid ten opzichte

Grafiek 5.4.2.2. Prijstijging in de gezondheidszorg en van de gezinsconsumptie, 1973-1975

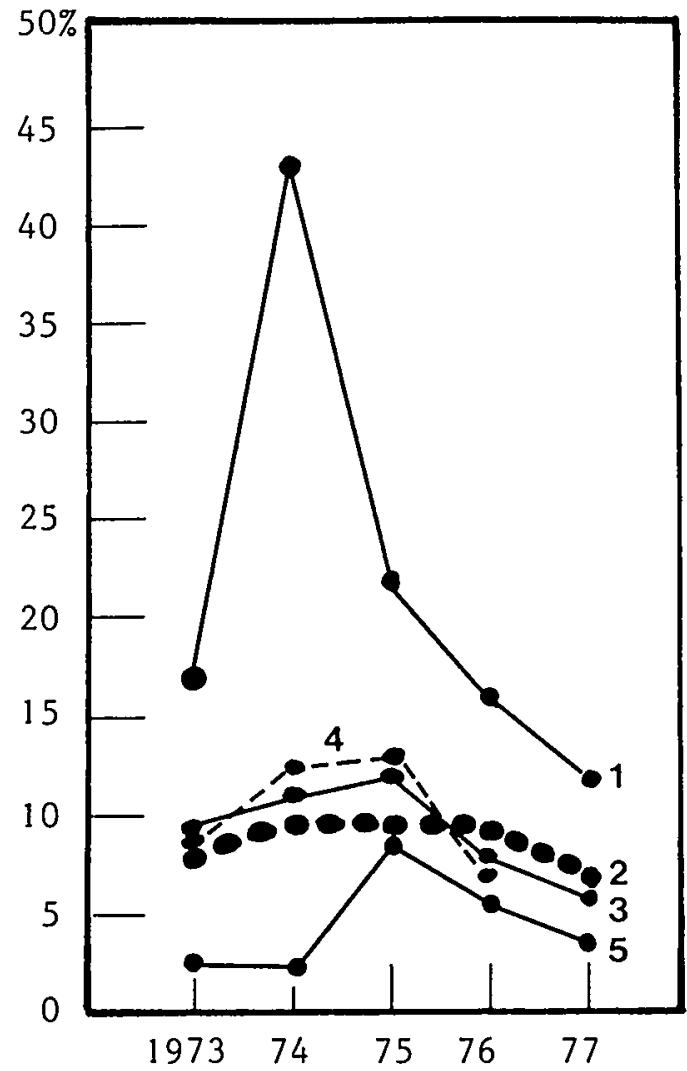

1 uitgavenstijging per verpleegdag in ziekenhuizen

2 prijsstijging gezinsconsumptie

3 tariefstijging specialistische hulp

4 prijsstijging huisartsenhulp fondspatiënten

5 prijsstijging geneesmiddelen

Bron: Ministerie van V\&M(57) 
van doorberekenen van inflatie en ten opzichte van richtlijnverruiming. De voor eigen rekening werkende beroepsbeoefenaren mogen slechts in beperkte mate de gevolgen van de inflatie in hun tarieven doorberekenen. Ten gevolge hiervan zijn in de afgelopen jaren de tarieven voor gezondheidszorg sneller afgenomen dan de algemene prijs- en loonsomstijgingen (zie grafiek 5.4.2.2.).

\subsubsection{Afremming van de groei van de premiedr}

Zoals in paragraaf 5.1.1. aangegeven, werd in 1970 door het kabinet-Den Uyl de éénprocentsoperatie ingevoerd. Voor het eerst werden hierbij voorstellen gedaan om door een beperking van de premiegroei de kosten van de gezondheidszorg af te remmen. De één-procentsoperatie had als gevolg, dat de totale kosten van de gezondheidszorg in 1980 circa $10 \%$ van het BNP zouden moeten bedragen in plaats van circa $11 \%$ bij ongewijzigd beleid $(C R V, 30)$. Op basis van deze één-procentsnorm werd door het Ministerie van $V \& \&$ geraamd op welke wijze de verschillende soorten voorzieningen zich in de komende jaren dienen te ontwikkelen (Ministerie van $V \&$ $M, 69)$. In 1978 werden in Bestek '81 (10) verdere beperkingen gelegd aan de groei van de collectieve bestedingen, waaronder te rekenen de gezondheidszorg. Op basis van Bestek '81 wordt een verdere daling van de groeisnelheid verwacht voor de verschillende soorten voorzieningen (zie grafiek 5.4.2.3.).

In totaal worden de kosten in 1982 geraamd op 33 mld. gulden hetgeen neerkomt op $9,2 \%$ van het BNP.

De groeibeperking van de kosten van de gezondheidszorg wordt niet als financiële beperking doorgegeven naar de verschillende sectoren van de gezondheidszorg. Zo wordt de groeivoet voor specialistenzorg van $\cdot 1979-1982$ van $6,5 \%$ (zie grafiek 5.4.2.3.) niet gebruikt om jaarlijks een aantal beschikbare nieuwe specialistenposten vast te stellen en te verdelen over de verschillende specialismen.

\subsubsection{Evenwichtige geografische spreiding}

De ontwikkeling van de geografische spreiding van de gezondheidszorg heeft in $\mathrm{Ne}$ derland tot voor kort weinig aandacht gekregen. Dit blijkt uit het ontbreken van statistische gegevens en concrete beleidsuitspraken hierover in verschillende daarvoor in aanmerking komende nota's van het Ministerie van Volksgezondheid en Milieuhygiëne en van de Centrale Raad voor de Volksgezondheid, zoals de Struktuurnota Gezondheidszorg (Ministerie van $V \& M, 68$ ) en het Eerste advies van Centrale Raad inzake regionalisatie in de gezondheidszorg $(C R V, 31)$. Eerst recentelijk wordt gepoogd statistische informatie over de kosten per gebied te verzamelen. Te vermelden is de poging van het Nederlands Instituut voor Preventieve Geneeskunde (NIPG) om de kosten van Friesland te berekenen (Petersen \& Akkerman, 78). Ook is te wijzen op de inspanningen om de kosten van het gebied Zuid-Limburg te bepalen (Rijksuniversiteit Limburg, 86).

Als studie naar regionale verschillen in het gebruik van ziekenhuisbedden is te noemen de studie van Rutten, Van Praag en Van Der Gaag (85). In hun studie maken zij een cross-section analyse van de klinische consumptie in 1969 en 1971. In deze laatste analyse verdelen Rutten c.s. Nederland in 120 ziekenhuisregio's. Een regio omschrijven zij als het verzorgingsgebied van één of (voor zover in dezelfde gemeente gevestigde) meer ziekenhuizen.

Gemeten in variatie-coëfficiënten, vinden $z i j$ verschillen bij verpleeghuisbedden $(69 \%)$, algemene ziekenhuisbedden (46\%), verpleegdagen (42\%) en specialisten per 100 algemene ziekenhuisbedden (35\%). Het aantal huisartsen per 1000 inwoners varieert het minste (15\%). De regionale verschillen in aantal opnamen per 1000 inwo- 

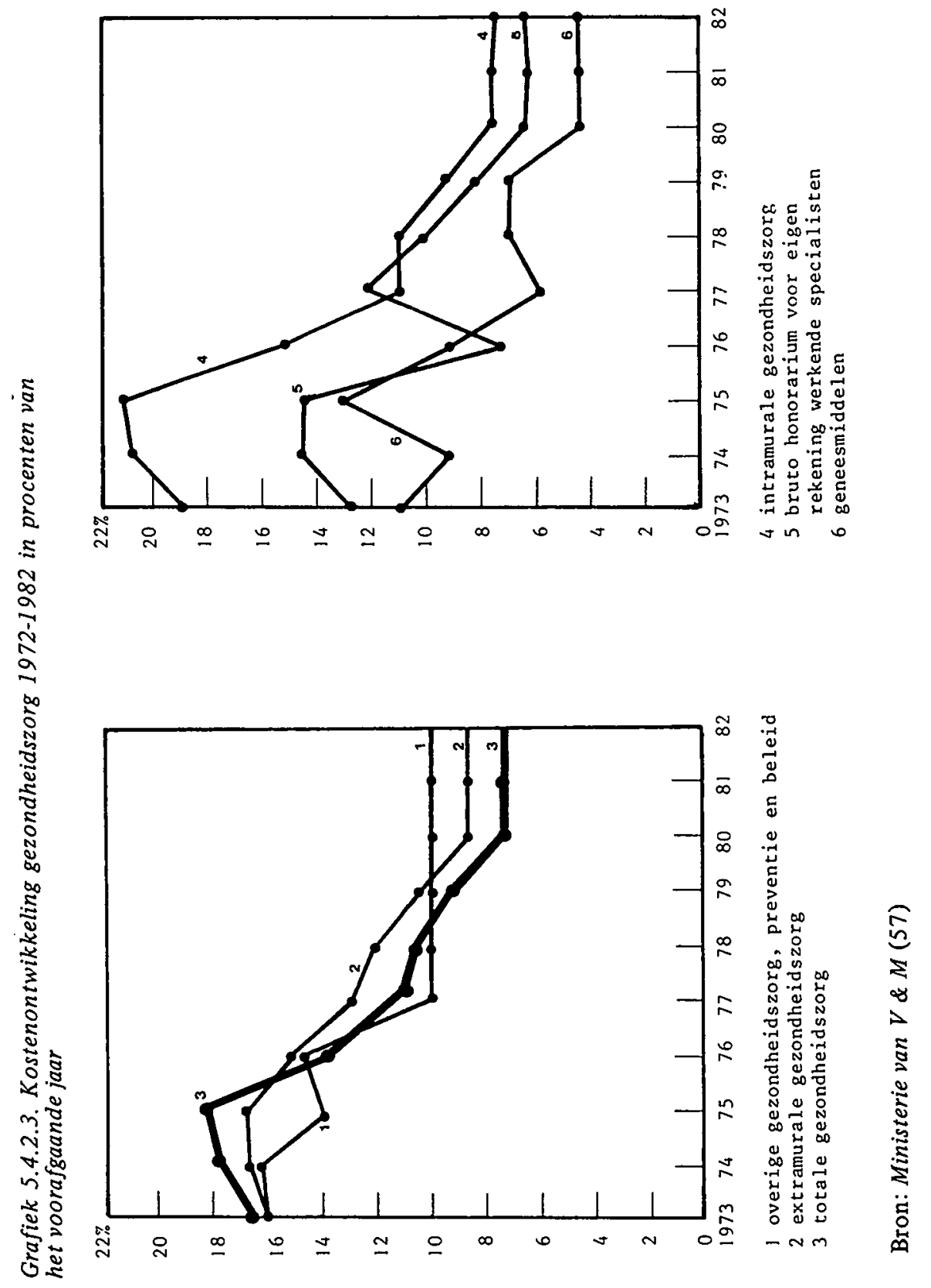

124 
Grafiek 5.4.3.1. Lasten per wettelijk verzekerde in 1975, als percentage van het landelijk gemiddelde $(100=f 659,38$ per wettelijk verzekerde in Nederland).

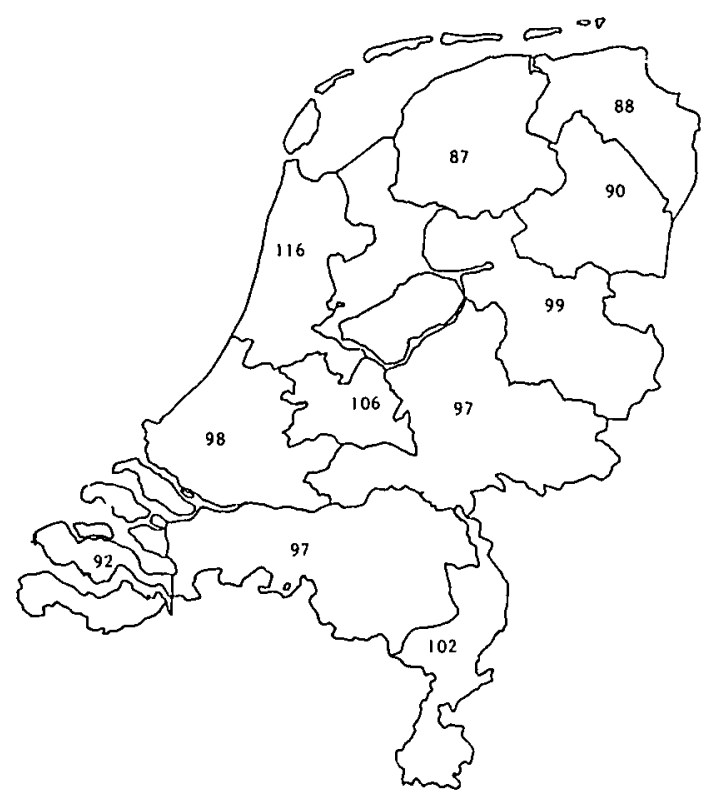

Bron: Ziekenfondsraad (94)

ners en in gemiddelde ligduur van algemene ziekenhuizen nemen een tussenpositie in (20 en $21 \%$ ). Het bestaan van geografische verschillen komt ook naar voren uit gegevens die fondsverzekerden betreffen. In grafiek 5.4.3.1. worden de kosten per wettelijke verzekerde van de ziekenfondsen per provincie aangegeven. Het getal 116 voor Noord-Holland betekent, dat per wettelijk verzekerde aldaar woonachtig, bij een ziekenfonds $16 \%$ meer wordt uitgegeven dan gemiddeld in Nederland per wettelijk verzekerde het geval is. Uit grafiek 5.4.3.1. is af te lezen, dat de noordelijke provincies het laagste en Noord-Holland en Utrecht het hoogste scoren. Uit het jaarboek 1975 van het LISZ (64) (Landelijk Informatie Systeem Ziekenfondsen) komt naar voren dat ook provinciale verschillen per verzekerde bestaan in aantallen ziekenhuisopnamen, verpleegdagen en verwijskaarten alsmede in het aantal verzekerden per huisarts. Verder blijken er grote regiogrensoverschrijdende patiënten-stromen te bestaan. Als voorbeeld voor deze verschillen tussen provincies worden in tabel 5.4.3.1. Groningen en Noord-Holland, met respectievelijk de laagste en hoogste lasten per wettelijk verzekerde, vergeleken met het nationale gemiddelde. Behalve voor de praktijkgrootte van de huisartsen scoort Groningen op de aangegeven grootheden lager dan Noord-Holland. 
Tabel 5.4.3.1. Verwijskaarten, opnamen, verpleegdagen, gemiddelde verpleegduur voor fondsverzekerden in Nederland, Groningen en Noord-Holland

\begin{tabular}{llll}
\hline & Nederland & Groningen & Noord-Holland \\
\hline Aantal verzekerden per huisarts & $100(=1922)^{*}$ & 93 & 90 \\
Aantal verwijskaarten per 1000 & $100(=486,2)$ & 96 & 107 \\
verzekerden & $100(=93,6)$ & 86 & 105 \\
Aantal opnamen per 1000 verz. & 105 & \\
Aantal verpleegdagen per 1000 & $100(=1969,8)$ & 83 & 113 \\
verzekerden & $100(=18,2$ dgn $)$ & 96 & 108 \\
Gemiddelde verpleegduur & & & \\
\hline
\end{tabular}

Bron: LISZ (64).

* Tussen haakjes staan de absolute aantallen.

Om te onderzoeken of de geografische verschillen sinds 1957 groter of kleiner zijn geworden is in grafiek 5.4.3.2. een aantal capaciteitscijfers uit 1957 en 1975 met elkaar vergeleken. Deze capaciteitscijfers betreffen het aantal algemene ziekenhuisbedden, het aantal medische specialisten, en het aantal huisartsen per 1000 inwoners per provincie. De cijfers geven geen beeld van de consumptie, maar van de aanwezige capaciteit van een provincie. Zowel in 1957 als in 1975 zijn de capaciteiten

Grafiek 5.4.3.2. Verdeling per provincie en per 1.000 inwoners van het aantal ziekenhuisbedden, medisch specialisten en huisartsen in 1957 en 1975.

Staande cijfers $=1975$

Cursieve cijfers $=1957$

Staande cijfers $=1975$

Cursieve cijfers $=1957$

\section{ZIEKENHUISBEDDEN}

Aantal ziekenhuisbedden per 1.000 inwoners

in Nederland in:

$19574,6(=1$ Uu $)$

$19755,2(=100)$

variatiecoëfficiënt

$195718 \%$

$197516 \%$

Bron: $G H I$ (46)

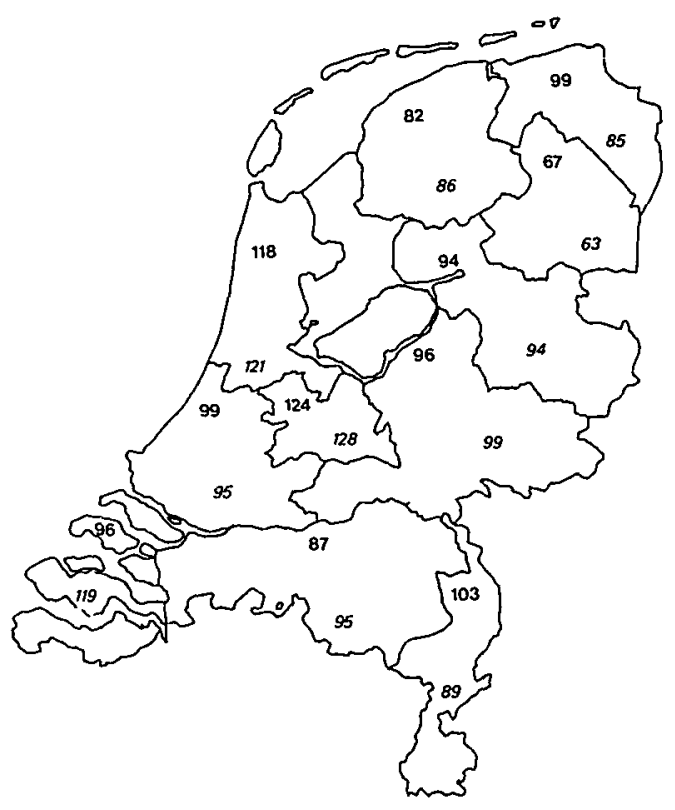


Grafiek 5.4.3.2. (vervolg)

\section{HUISARTSEN}

Aantal huisartsen per 1.000 inwoners in Nederland in:

$19570,378(=100)$

$19750,359(=100)$

variatiecoëfficiënt

$195714 \%$

$19759 \%$

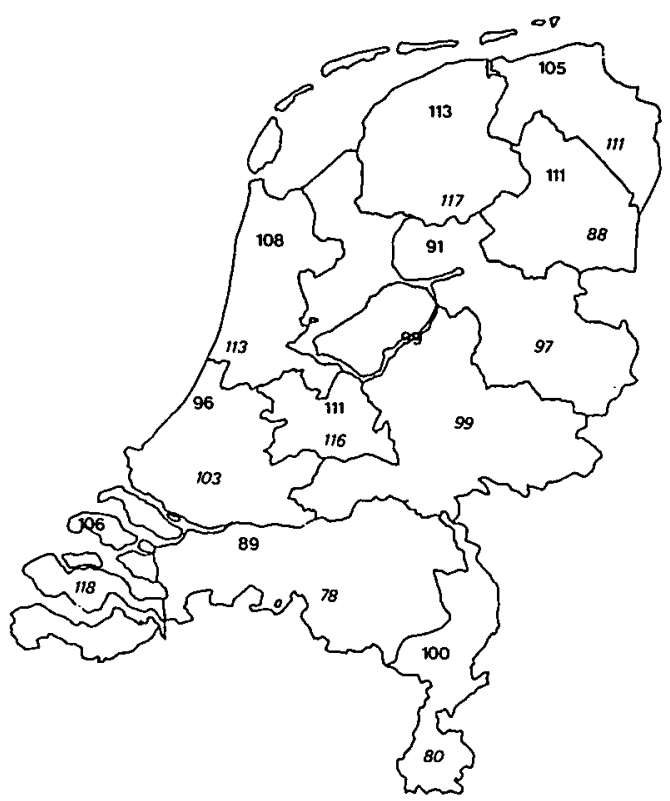

MEDISCH SPECIALISTEN Aantal medisch specialisten per 1.000 inwoners in Nederland in:

$19570,3(=100)$ $19750,6(=100)$ variatiecoëfficiënt $195737 \%$ $197529 \%$

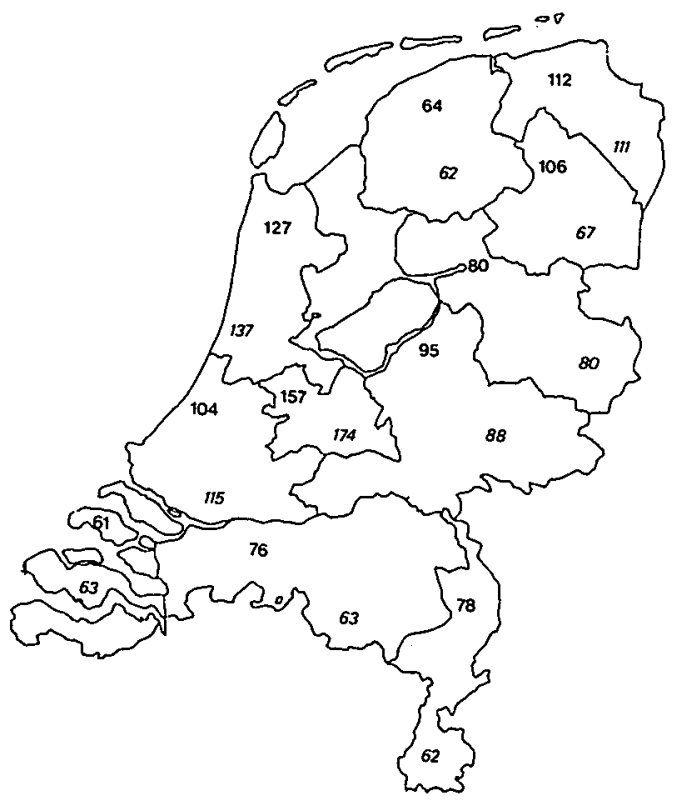


gemeten als index, gebaseerd op het nationaal gemiddelde. De regionale verschillen, gemeten in variatie-coëfficiënten, zijn voor de huisartsendichtheid het geringste (37 en $29 \%$ ). Voor de beddendichtheid van algemene ziekenhuizen bedraagt de variatiecoëfficiënt in $195718 \%$ en in $197516 \%$. Opvallend is, dat de variatie-coëfficiënten voor de drie capaciteitsgrootheden in 1975 lager zijn dan in 1957. Wel blijken de ontwikkelingen in de verschillende provincies autonoom ten opzichte van elkaar te zijn verlopen. Relatief welvoorziene provincies in 1957 blijken in 1975 soms ondervoorzien te zijn, terwijl ook het omgekeerde voorkomt. De optredende provinciale verschillen kunnen met uiteenlopende faktoren in verband worden gebracht, zoals de aanwezigheid van academische ziekenhuizen, opleidingsziekenhuizen, een bovenregionale funktie van een ziekenhuis, de morbiditeit en de zorgconsumptie van de bevolking, en het gevoerde beleid.

\subsubsection{Integratie zorgverlening}

In tabel 5.4.2.3. is de groei voor de komende jaren aangegeven voor de verschillende voorzieningen van gezondheidszorg. Om deze groeicijfers te bereiken staan de overheid de instrumenten ter beschikking die in de vorige paragrafen besproken zijn. Alle beleidsinstrumenten gaan ervanuit, dat het particulier initiatief een bepaalde verandering wil, die de rijksoverheid door haar beleid kan stimuleren of afremmen. De overheid is niet in staat om zelf veranderingen te entameren zonder de bereidheid van het particulier initiatief hiervoor te verwerven. $\mathrm{Zij}$ is niet in staat een funktieverandering van een ziekenhuis af te dwingen, bijvoorbeeld van klinische naar poliklinische aktiviteiten of van behandeling van acute zieken naar die van chronische zieken. Uit reakties op de Struktuurnota Gezondheidszorg blijken de vele organisaties van particuliere initiatiefinstellingen zich te kunnen vinden in de prioriteiteristelling voor de ontwikkeling van de verschillende voorzieningen $(C R V, 32)$. De besluitvormingsstruktuur weerhoudt de voorzieningen echter om zelf tot funktieverandering over te gaan. Een aantal voorbeelden hiervan zijn de volgende:

- een ziekenhuis wordt per verpleegdag gefinancierd. Indien een ziekenhuis nu in een projekt deelneemt om de extramurale en poliklinische zorg te stimuleren, zal dit voor het betrokken ziekenhuis leiden tot minder verpleegdagen en daardoor minder inkomsten. Aangezien de kosten van een ziekenhuis ten opzichte van het aantal verpleegdagen op de korte termijn van hoofdzakelijk vast karakter zijn, leidt deelname aan het genoemde projekt tot financiële tekorten voor het betrokken ziekenhuis. Voor een ziekenhuis in Hoogeveen, dat aan een dergelijk projekt deelneemt, daalde de bezettingsgraad van $90 \%$ in 1972 naar $80 \%$ in 1976 . "De jaarlijks veroorzaakte exploitatieverliezen liepen hierdoor enorm op", aldus een verslag van het Ziekenhuis Bethesda (118).

een tweede voorbeeld betreft huisartsen die in een samenwerkingsverband meer zorg willen verlenen aan de patiënten dan voor solo-huisartsen gebruikelijk is. Door deze extra-zorg kan meer aandacht aan psycho-sociale problematiek en aan ziekenhuisnazorg worden verleend. Het abonnementstarief voor fondsverzekerden van een huisarts houdt echter een vast bedrag per patiënt per jaar in, ongeacht de hoeveelheid zorg besteed per patiënt. Indien een huisarts nu extra zorg wil verlenen en overgaat tot praktijkverkleining, betekent dit een inkomensverlies. Dit inkomensverlies wordt gezien als een van de grote problemen om samenwerkingsverbanden te starten. Om dit probleem enigszins op te lossen heeft de Ziekenfondsraad geadviseerd gezondheidscentra gedeeltelijk op basis van budgetten te financieren (Ziekenfondsraad, 117).

- het inhoud geven aan de gedachte van zorgketens verloopt moeizaam. Deze gedachte gaat uit van een op elkaar aansluitende zorgverlening voor dezelfde 
cliëntengroep. Zo zijn zorgketens denkbaar voor demente bejaarden, druggebruikers, jeugdgezondheidszorg en personen met behoefte aan psycho-sociale hulpverlening. Bij de eerstgenoemde groep is te denken aan de gestruktureerde relatie: sociaal-geriatrische dienst - ziekenhuis - verpleeghuis. Bij de druggebruikers: voorlichting en preventie - opvangcentrum - afkickboerderij - halfweg-huis. Voor de jeugdgezondheidszorg is aan ketens te denken als: huisarts-wijkverpleging schoolarts - kinderarts. Bij de psycho-sociale hulpverlening is als keten denkbaar: algemeen maatschappelijk werk - instellingen voor ambulante geestelijke gezondheidszorg - psychiatrische ziekenhuizen. In de gemeente Utrecht - evenals in andere steden - ondervindt deze integratie van zorg wel steun, maar verloopt ze toch moeizaam ten gevolge van een aantal strukturele faktoren. Ten eerste vallen de verzorgingsgebieden van de verschillende zorgverleners vaak niet samen, hetgeen de communicatie en het overleg bemoeilijkt. Dit is bijvoorbeeld in Utrecht het geval bij huisartsen en wijkverpleegkundigen. Ten tweede kan een verschil in financiering en arbeidsvoorwaarden een grote drempel vormen om tot een samengaan over te gaan (bijvoorbeeld van een academisch en een algemeen ziekenhuis). Ten derde moeten instellingen vanwege de financiële strukturen soms hun eigen doelstellingen centraal stellen, die evenwel niet geheel samenvalt met de regionale doelstelling.

- kleine ziekenhuizen hebben moeite met hun voortbestaan, omdat ze niet in staat zijn een aantal taken van hun organisatie te centraliseren. Hierbij is te denken aan de opleiding van verpleegkundigen, het opzetten van een medisch beleid en het introduceren van de automatisering in de administratie. Deze taken zouden eenvoudiger op te zetten zijn door een aantal ziekenhuizen gezamenlijk. Vanwege de concurrentiepositie tussen ziekenhuizen, die voor hun inkomsten elk aangewezen zijn op dezelfde bevolkingsgroepen, komt van dit soort samenwerking echter weinig terecht (zie uitgebreid: Boot-Zuidberg, 13).

- als laatste voorbeeld is te wijzen op de moeilijkheden vanwege verschillende financieringsvormen bij de vorming van RIAGG's. De oorspronkelijke instellingen, waaruit een RIAGG moet ontstaan, moeten van de subsidiërende instanties (Ziekenfondsraad, Ministeries van Cultuur, Recreatie en Maatschappelijk Werk en van Volksgezondheid en Milieuhygiëne, alsmede lokale overheden) financieel herkenbaar blijven, hetgeen een herordening van taken bemoeilijkt.

De bovengenoemde voorbeelden illustreren het feit, dat in de Nederlandse gezondheidszorg regionale besluitvormingskaders ten aanzien van samenwerking tussen instellingen ontbreken. Er is slechts samenwerking mogelijk, indien alle betrokken instellingen en instanties tot overeenstemming komen.

\subsubsection{Vergroten betrokkenheid van patiënten en medewerkers}

\subsubsection{Satisfactie van patiënten en medewerkers}

In 1976 heeft Bergsma (9) een landelijk onderzoek gehouden naar ziekenhuiservaringen van ruim 700 ex-patiënten. Deze patiënten waren afkomstig uit gemeenten met een verschillende urbanisatiegraad en met een volgens Bergsma "goede regionale spreiding". De patiënten werden getrokken uit een aantal huisartsenpraktijken en geinterviewd kort na het ontslag uit het ziekenhuis. Van de geënqueteerde patiënten was $24 \%$ ouder dan 65 jaar; $58 \%$ was van het vrouwelijke geslacht; $35 \%$ had een werkkring en $40 \%$ een diploma van de MAVO of een hogere onderwijsinstelling. Van de zeventig voorgelegde opiniërende stellingen met geprecodeerde antwoordcategorieën volgen hieronder enkele cijfers die een indruk geven van de satisfactie van deze patiënten. 
helemaal waar/ beetje onwaar/

beetje waar

helemaal onwaar weet niet/ onbekend

De artsen, die mij behandelden, waren erg aardig

$96 \%$

De verpleegsters waren vriendelijk $96 \%$

onbekend

Ik vond het ziekenhuis net een

fabriek

Ik had een zeer kundige dokter

Ik kreeg in het ziekenhuis veel

aandacht

Ik had de indruk, dat het zieken-

huis goed georganiseerd was

Ik heb veel kritiek op de manier,

waarop men mij in het ziekenhuis

heeft behandeld

\section{$20 \%$}

$90 \%$

$2 \%$

$2 \%$

$2 \%$

$78 \%$

$76 \%$

$1 \%$

$4 \%$

$9 \%$

$82 \%$

$16 \%$

$6 \%$

$13 \%$

$5 \%$

$9 \%$

$88 \%$

$3 \%$

Bron: Bergsma (9).

Uit de antwoorden op bovenstaande statements komt het beeld naar voren dat het grootste deel van de ondervraagde patiënten zeer tevreden is.

Over de tevredenheid van patiënten over andere soorten zorgverlening zijn geen landelijke onderzoeken beschikbaar.

Over de arbeidssatisfactie van medewerkers bleken evenmin onderzoeksgegevens aanwezig te zijn. Uit publicaties in de vakpers en uit contacten vanuit het Instituut voor Ziekenhuiswetenschappen komt de indruk naar voren van een stijgende werkbelasting voor de medewerkers gedurende de laatste jaren. Met name het tekort aan verpleegkundigen in de ziekenhuizen wordt regelmatig genoemd.

\subsubsection{Inspraak van medewerkers en patiënten}

De inspraak van medewerkers op het nationale en regionale niveau vindt plaats in adviesorganen, waarin naast medewerkers ook werkgeversorganisaties, vakbonden, ziekenfondsen, particuliere verzekeringsinstellingen en onafhankelijke deskundigen zitting kunnen hebben. De landelijke adviesorganen (zie paragraaf 5.2.1.) en plaatselijke overlegorganen (zie paragraaf 5.3.1.) zijn op deze wijze samengesteld. Door deze wijze van advisering kan het voorkomen, dat eenzelfde organisatie via verschillende adviesorganen meer dan een keer aan de rijksoverheid adviseert. Dit levert doublures op in de advisering, temeer daar verschillende organisaties ook rechtstreeks naar buiten treden. Zo publiceerde de Koninklijke Nederlandse Maatschappij ter bevordering van de Geneeskunde (KNMG) haar standpunt over de wetsontwerpen Voorzieningen Gezondheidszorg en Tarieven Gezondheidszorg in twee memoranda $(K N M G, 62)$. Daarnaast had de KNMG een aandeel in de advisering van de verschillende nationale adviesorganen met betrekking tot deze wetsontwerpen. Hetzelfde is te stellen voor andere maatschappelijke organisaties. Ten gevolge van de verschillende posities van de participanten in de adviesorganen lijkt er bij belangrijke adviezen zelden sprake te zijn van een unanieme advisering (zie bijvoorbeeld $C R V, 31$ en 32, Ziekenfondsraad, 112, 115 en 116).

Ten aanzien van de inspraak van medewerkers binnen een instelling is de aanwezigheid van ondernemingsraden te noemen. Naar deze raden werd vanuit het buitenland 
- zo bleek uit de interviews in Engeland en Zweden - met interesse gekeken.

Ten aanzien van de patiënten wordt hier volstaan met een citaat uit de Struktuurnota Gezondheidszorg (Ministerie van $V \& M, 68$, p. 5): "De inspraak van de bevolking in de ontwikkeling van de gezondheidszorg en in het funktioneren van de voorzieningen is onvoldoende tot ontwikkeling gekomen".

De regeling van de inspraak voor medewerkers en patiënten staat thans ter discussie. (Gezondheidszorg en Democratisering, 45, Van Wijmen, 111, Commissie van de Burg, 25). 


\section{REGIONALISATIE EN FINANCIERING VAN DE NEDERLANDSE GEZONDHEIDSZORG OP MIDDELLANGE TERMIJN}

\subsection{INLEIDING}

In paragraaf 1.2. is als probleemstelling van deze studie geformuleerd: "Aan welke voorwaarden moet een financieringsstelsel van de Nederlandse gezondheidszorg voldoen, dat gebaseerd is op de volgende uitgangspunten:

- een regionalisatie van de formele organisatiestruktuur van de gezondheidszorg

- het leveren van een positieve bijdrage aan het bereiken van thans geldende doelstellingen van het nationale beleid ten aanzien van de gezondheidszorg

- de mogelijkheid op middellange termijn te worden verwezenlijkt vanuit het thans bestaande financieringsstelsel".

In par. 6.2. wordt de omgeving van de gezondheidszorg van elk van de drie landen vergeleken en geanalyseerd op samenhangen met de formele organisatiestruktuur van de gezondheidszorg. In par. 6.3. komt de vergelijking aan de orde van de formele organisatiestruktuur van de gezondheidszorg in de drie landen. Gekeken wordt naar relaties van deze struktuur met de besluitvormingsstruktuur.

In par. 6.4. worden voorwaarden geformuleerd aan de besluitvormingsstruktuur. Dit gebeurt op basis van een vergelijking van besluitvormingsstrukturen van de drie landen. De voorwaarden concentreren zich op het financieringsstelsel als deel van de formele besluitvormingsstruktuur.

In par. 6.5. worden te verwachten positieve bijdragen van een op deze voorwaarden opgezet financieringsstelsel geformuleerd. Dit gebeurt door de doelstellingskenmerken van de drie landen te vergelijken en te analyseren op hun samenhang met het financieringsstelsel.

\subsection{ALGEMENE KENMERKEN}

\subsubsection{Demografische en macro-economische kenmerken}

In tabel 6.2.1. worden enige demografische en macro-economische kenmerken van de drie landen tegen elkaar afgezet. Naar aanleiding van deze tabel zijn de volgende opmerkingen te maken:

- de bevolkingsomvang van Engeland is een aantal malen groter dan die van Nederland en Zweden. De gemiddelde bevolking van een AHA in Engeland is groter dan van een landsting in Zweden. De health areas variëren in inwonertal van 100.000 tot 2,4 miljoen inwoners. Voor de Zweedse landstingen zijn deze aantallen 125.000 en 1,5 miljoen inwoners.

- de ontwikkeling van de bevolkingssamenstelling is in elk van de drie landen overeenkomstig. Het percentage bejaarden van de bevolking in de drie landen stijgt 
over de periode 1950-1975. In de drie landen wordt verwacht, dat deze ontwikkeling zich zal voortzetten (zie tabellen 2.1.1., 4.1.1. en 5.1.1.1.). Het aandeel in de bevolking van de bejaarden ligt in Nederland wel lager dan in de twee andere landen. Het geboortecijfer daalt in de drie landen over de aangegeven periode. Verwacht wordt voor de periode tot 1990 dat het geboortecijfer in Engeland zal stijgen, in Zweden gelijk zal blijven en in Nederland zal dalen (zie par. 2.1.1., 4.1.1.en 5.1.1.).

- de bevolkingsdichtheid is in Zweden aanmerkelijk lager dan in beide andere landen.

- de beroepsbevolking; gemeten als percentage van de totale bevolking bedraagt in Nederland $29 \%$, in het Verenigd Koninkrijk $46 \%$ en in Zweden $49 \%$ (zie par. 2.1.1., 4.1.1. en 5.1.1.). De beroepsbevolking in de drie landen is voor een gering deel werkzaam in de landbouw en de visserij en voor 30 à $40 \%$ werkzaam in de industrie. De meerderheid werkt in de dienstverlenende sektoren.

- de drie landen worden over de periode 1950-1975 gekenmerkt door een groei van het BNP, zowel gemeten in lopende als in konstante prijzen. De economische groei van de drie landen sinds 1973, gemeten als de jaarlijkse volumegroei van het $\mathrm{BNP}$, is lager dan die in de jaren zestig. De drie landen maken elk thans de ern-

Tabel 6.2.1. Vergelijking van de demografische en macro-economische kenmerken van de drie landen

\begin{tabular}{lcccc}
\hline & & & & \\
& & Engeland & Zweden & Nederland \\
\hline Bevolkingsomvang in mln. & 1950 & 41,4 & 7,0 & 10,2 \\
& 1975 & 46,5 & 8,2 & 13,7 \\
Gemiddelde bevolkingsomvang per regio & & 460 & 315 & 1300 \\
in 1975 (X 1000) & & 100 & 125 & 335 \\
minimumomvang & & 2400 & 1500 & 3000 \\
maximumomvang & 1950 & $10,9 \%$ & $10,2 \%$ & $7,7 \%$ \\
waarvan 65 jaar en ouder & 1975 & $14,1 \%$ & $14,6 \%$ & $10,9 \%$ \\
& 1950 & 16,7 & 16,5 & 22,7 \\
Aantal levend geborenen per 1000 & 1975 & 12,2 & 13,5 & 13,0 \\
inwoners & 1975 & 360 & 20 & 402 \\
Aantal inwoners per km ${ }^{2}$ & 1975 & $24,8^{2}$ & 42 & 4,7 \\
Beroepsbevolking in mln. arbeidskrachten & 1975 & $2,8 \%$ & $6,7 \%$ & $6,4 \%$ \\
waarvan - landbouw en visserij $\quad$ industrie & 1975 & $42,3 \%$ & $37,0 \%$ & $33,7 \%$ \\
$\quad$ - dienstverlenende sektoren & 1975 & $54,9 \%$ & $56,3 \%$ & $59,9 \%$ \\
Bruto Nationaal Produkt tegen markt- & 1950 & $23^{2}$ & 18 & 19 \\
prijzen (BNP) (1970 = 100) & 1975 & $203^{2}$ & 168 & 182 \\
BNP in \$ per inwoner & 1950 & $670^{4}$ & 810 & 520 \\
BNP in constante prijzen (1970 = 100) & 1975 & 4240 & 8420 & 5990 \\
& 1950 & $59^{4}$ & 48 & 40 \\
& 1975 & 110 & 112 & 117 \\
\hline
\end{tabular}

Bron: zie tabellen 2.1.1., 4.1.1. en 5.1.1.1.

1 Engeland: AHA, Zweden: landsting, Nederland: provincies.

2 UK.

31974.

4 BNP tegen faktorkosten. 
stigste economische recessie mee sinds 1950 (zie par. 2.1.1., 4.1.1. en 5.1.1.). Het BNP per inwoner, omgerekend in Amerikaanse dollars is in Engeland in 1975 lager dan in Nederland en Zweden.

Hieronder wordt van elk van deze kenmerken aangegeven, wat in Engeland en Zweden de relaties zijn met de formele organisatiestruktuur. Op basis hiervan wordt voor Nederland een aantal uitgangspunten voor de regionale struktuur uitgewerkt.

\section{Bevolkingsomvang en -samenstelling, in totaal en per regio}

De veranderde bevolkingssamenstelling lijkt in Engeland en Zweden één van de overwegingen geweest te zijn om tot regionalisatie van de gezondheidszorg over te gaan. De veroudering van de bevolking leidt tot andere zorgbehoeften, die vragen om een grotere afstemming daarop en verschuivingen in de verschillende soorten verleende zorg. Deze zienswijze gaat ook op voor Nederland: de relatieve veroudering van de bevolking zal om steeds meer afstemming tussen en verschuivingen in de zorgverlening vragen.

In Engeland wordt deze afstemming op regionaal niveau verwezenlijkt in de health areas en de health districts en in Zweden in de landstingen. In Engeland vormen de veertien RHA's een schakel tussen de AHA's en DMT's enerzijds en het DHSS anderzijds. Hun taken bestaan uit het uitwerken van DHSS-richtlijnen en het integreren van het beleid van de AHA's en DMT's (zie par. 3.2.). In Zweden worden deze taken uitgevoerd op nationaal niveau door de Socialstyrelsen en de Landstingförbundet. Voor een aantal topklinische funkties zijn de zogenaamde zeven "ziekenhuisregio's" gevormd (zie par. 4.2.1.). Een toepassing in Nederland van de Engelse en Zweedse stelsels vraagt om gezondheidszorgregio's in de grootte van 100.000 tot 2,5 miljoen inwoners. Deze gezondheidszorgregio's kunnen daarom en vanwege de aansluiting op het bestaande beleid het beste worden gevormd door de Nederlandse provincies, die qua inwonertal variëren van 335.000 tot 3 miljoen inwoners. Wel is het zo, dat het model in principe ook toepasbaar is voor grote steden en gewesten met meer dan 100.000 inwoners.

In Zweden bestaan drie managementniveau's: het werkeenheids-, het regionale- en het nationale niveau.

In Engeland is gekozen voor vier bestuurslagen. De bevolkingsomvang van 46,5 miljoen inwoners was een overweging om de relaties tussen het DHSS en de AHA's en districts via de RHA te laten verlopen. Voor Nederland vervalt deze overweging, omdat het aantal inwoners kleiner is. Bovendien blijkt in Engeland de aanwezigheid van meer dan drie bestuurslagen remmend te werken op de besluitvorming (zie par. 3.2.4.). Al met al wijzen de ervaringen in Engeland en $\mathrm{Zweden} \mathrm{erop} \mathrm{dat} \mathrm{een} \mathrm{regiona-}$ le indeling in Nederland niet meer dan drie bestuurslagen zal moeten tellen. Hierbij is te denken aan bestuurslagen op nationaal, regionaal en werkeenheidsniveau. Wel zal voor een aantal topklinische funkties een aantal verzorgingsgebieden groter dan één provincie tot stand moeten komen, zoals in Zweden nu het geval is (zie par. 4.2.). Over de vorming van subregio's binnen één provincie kan in Nederland beter plaatselijk worden geoordeeld, zo leren de ervaringen in Engeland en Zweden: in Engeland moeten enkele jaren na de reorganisatie de nationale beslissingen over de indeling van AHA's in districts worden herzien. In Zweden wordt de ontwikkeling naar subregio's door de landstingen zelf bepaald. Deze ontwikkeling lijkt geleidelijker en zonder de problemen van Engeland te verlopen.

Tenslotte is over de bevolkingssamenstelling het volgende op te merken. Regionale financiering komt in Engeland en Zweden voor in regio's, die onderling grote verschillen vertonen in de samenstelling van de bevolking: een dergelijke financiering bestaat zowel in regio's met een vergrijzende bevolking (Zuid-Engeland, Noord-Zwe- 
den) als in gebieden met nieuwe steden en een jonge bevolking. De samenstelling van de beroepsbevolking blijkt evenmin van invloed te zijn op de aanwezigheid van regionale financiering. Zowel in agrarische gebieden als in grote steden komt ze voor.

\section{Bevolkingsdichtheid}

De bevolkingsdichtheid in Zweden is laag vanwege de dunbevolkte noordelijke landstingen. In Zuid- en Midden-Zweden komen bevolkingsdichtheden voor die te vergelijken zijn met die van Nederland, zoals in de landsting Stockholm. We zien in Zweden dat regionale financiering zowel voorkomt in dunbevolkte als in dichtbevolkte gebieden, zodat de bevolkingsdichtheid kennelijk in deze context geen rol speelt. Wel zal een dunbevolkt gebied andere eisen stellen aan de spreiding van werkeenheden. Om dichtbij de bevolking te blijven zullen deze in het algemeen kleiner moeten zijn. Aan deze struktuur is door de formele besluitvorming van het regio-orgaan tegemoet te komen. Verder is te verwachten, dat twee dichtbevolkte regio's grotere cross-boundary flows kennen, aangezien er meer mensen langs de regiogrenzen wonen. In Nederland bestaat thans veel provincie-overschrijdend patiëntenverkeer (zie LISZ-Jaarboek, 64). Een regiostruktuur zal hiermee rekening hebben te houden.

\section{Bruto Nationaal Produkt}

De hoogte van het BNP in Nederland, gemeten in US \$ per inwoner, ligt tussen die in Engeland en Zweden. Het is niet te stellen, dat de hoogte van het Nederlandse BNP een regionale struktuur verhindert. Wel is er een verband tussen de ontwikkeling van het BNP in de drie landen en die van de doelstellingen. Zo hangen de stakingen in de Engelse gezondheidszorg samen met de algemene, macro-economische ontwikkeling en niet met de regionale strukturen. Hetzelfde geldt voor de relatieve luxe van de Zweedse intramurale instellingen.

\subsubsection{Gezondheidstoestand van de bevolking}

Bij het vergelijken van de drie landen op gezondheidstoestand van de bevolking wordt volstaan met een aantal kriteria voor de somatische gezondheidstoestand. Zoals in de desbetreffende paragrafen 2.1.2., 4.1.2. en 5.1.2. aangegeven, zijn over andere kriteria over psychosociaal welbevinden en zorgbehoeften weinig - laat staan internationaal vergelijkbare - gegevens beschikbaar.

Overeenkomstige kenmerken van de somatische gezondheidstoestand van de bevolking van de drie landen zijn de volgende (zie tabel 6.2.2.):

- de gemiddelde verwachte levensduur (van nul-jarigen) stijgt in de drie landen gedurende de laatste 25 jaar. Voor vrouwen is deze stijging groter dan voor mannen.

- de perinatale sterfte daalt in de drie landen sinds 1950 met 19 sterfgevallen per 1000 geborenen.

- het mortaliteitspatroon verandert in elk van de landen. Het percentage sterfgevallen ten gevolge van kwaadaardige nieuwvormingen of hart- en vaatziekten ligt in 1950 in Engeland en Zweden op 53\% en in Nederland op 39\%. In 1975 ligt dit percentage voor elk van de drie landen boven de $70 \%$.

De verschillen in gezondheidstoestand betreffen:

- zowel in 1946-1950 als in 1975 is de levensverwachting van de Britten lager dan in de beide andere landen, die onderling weinig verschillen.

- de perinatale sterfte ligt in Engeland, zowel in 1950 als in 1975, boven die van Nederland en Zweden.

- de mortaliteit per 100.000 inwoners ligt in Nederland beneden die van de twee andere landen.

Een verklaring voor de lagere scores in levensverwachting en hogere scores in perina- 
Tabel 6.2.2. Vergelijking van de gezondheidstoestand van de bevolking van de drie landen

\begin{tabular}{lllll}
\hline & & Engeland & Zweden & Nederland \\
\hline Gemiddelde verwachte levensduur van & 1950 & 66,3 & $69,0^{1}$ & $70,6^{4}$ \\
mannen & 1975 & 69,5 & $72,1^{2}$ & 71,4 \\
Gemiddelde verwachte levensduur van & 1950 & 71,0 & 71,6 & 72,9 \\
vrouwen & 1975 & 75,7 & 77,6 & 77,6 \\
Perinatale sterfte per 1000 geborenen & 1950 & 38,0 & 32,3 & 34,2 \\
& 1975 & 19,3 & 13,3 & 13,9 \\
Mortaliteit per 100.000 inwoners & 1950 & 1234 & $963^{3}$ & 750 \\
& 1975 & 1184 & $1081^{3}$ & 833 \\
waarvan sterfgevallen ten gevolge van & 1950 & $53 \%$ & $53 \%$ & $39 \%$ \\
nieuwvormingen of hart- en vaatziekten & 1975 & $73 \%$ & $76 \%$ & $71 \%$ \\
\hline
\end{tabular}

Bron: zie tabellen 3.1.2., 4.1.2. en 5.1.2.

1 1946-1950.

2 1971-1975.

3 1951-1955.

4 1950-1952.

tale sterfte is moeilijk te geven. Een belemmering voor de toepasbaarheid van regionale strukturen in Nederland hoeven deze lagere scores in Engeland niet te vormen. Ten eerste komt een dergelijk stelsel ook voor in het wel op dit punt vergelijkbare Zweden. Ten tweede kennen de RHA's binnen Engeland onderling ook grote verschillen in de verschillende kriteria voor de gezondheidstoestand (zie par. 3.3.2.2.1.). De lagere mortaliteit in Nederland hangt samen met de geringere vergrijzing van de Nederlandse bevolking.

\subsubsection{Organisatie van het overheidsbestel}

De drie landen kennen elk een parlementaire democratie met vrije ondernemingsgewijze produktie, die globaal door de rijksoverheid wordt geordend. Verschillen in het overheidsbestel bestaan er tussen enerzijds Engeland en Nederland en anderzijds Zweden. De rijksoverheid in dit laatste land kent een scheiding van beleidsformulering en beleidsuitvoering. Ook is het eigen belastinggebied van de lagere overheden in Zweden groter dan in Engeland en Nederland. Het aandeel van de lagere overheden in de belastingontvangsten is in het eerstgenoemde land $32 \%$ en in de laatstgenoemde 13 resp. 15\% (zie par. 2.1.3., 4.1.5. en 5.1.3.).

In Engeland en Zweden is de regionalisatie van de gezondheidszorg gelijk opgegaan met de reorganisatie van het binnenlands bestuur (par. 2.1.3. en 4.1.3.). In Nederland lijkt de reorganisatie van het binnenlands bestuur gelijktijdig te gaan verlopen aan de regionalisatie van de gezondheidszorg (zie par. 1.1. en 5.1.3.). Gemist wordt thans in Engeland en Zweden het onder één bestuur zijn van én gezondheidszorg én maatschappelijke dienstverlening. Voor Nederland is dit gebrek te voorkomen, indien het bestuur van een gezondheidsregio wordt gevormd door hetzelfde bestuur, dat ook regionale verantwoordelijkheid draagt voor de maatschappelijke dienstverlening. Meestal zal dit het provinciaal bestuur zijn, maar grote gemeenten of gewesten kunnen ook in aanmerking komen.

De relatie tussen de overheid en de gezondheidszorg lijkt in Engeland en Zweden 
ogenschijnlijk van andere aard te zijn dan in Nederland. Is in de eerste twee landen I sprake van een organisatie van de gezondheidszorg op publiekrechtelijke, "genationaliseerde" grondslag, in Nederland is deze grondslag toch vooral van privaatrechtelijk, "particuliere" aard.

Nadere bestudering leert, dat deze verschillen in grondslag thans van geringere invloed lijken te worden. Het vroegere spanningsveld in Nederland tussen "overheid" en "particulier initiatief" is meer een spanningsveld geworden tussen nationale beleidsbepalende instanties enerzijds en uitvoerende werkeenheden en hun organisaties anderzijds (Ter Heide en Kalff, 55 en Idenburg, 58).

Het eerste spanningsveld komt ook in Engeland voor in de relatie tussen de "civil servants" van het DHSS en de "staff" van de NHS en in Zweden tussen de Socialstyrelsen en het Socialdepartementet aan de ene kant en de landstingen aan de andere kant (zie par. 2.4.4., 3.4.4. en 4.4.4.). Binnen een regio ontstaan in beide landen op zich weer spanningsvelden tussen bijvoorbeeld het DMT en de sector en unit administrators (in Engeland) en het landstingsbestuur en de blokhoofden (in Zweden). Uitgaande van drie bestuurslagen voor de gezondheidszorg in Nederland betekent dit, dat de derde bestuurslaag gevormd zou kunnen worden door de besturen van de thans overwegend particuliere instellingen. Hierdoor blijft een managementniveau voor de werkeenheid gehandhaafd, waarvan het verdwijnen in Engeland toch wel problemen oplevert (par. 3.4.4.). Het behoud van dit niveau verdient ook aanbeveling vanuit de overweging om zonder grote moeite aan te sluiten op historisch gegroeide patronen. Welke beslissingsruimte in een nieuwe regionale struktuur in Nederland beschikbaar is voor de besturen van de werkeenheden kan dan worden afgeleid uit die van het overeenkomstige "multi unit management" in Engeland en Zweden (zie par. 6.4.).

\subsection{ORGANISATIESTRUKTUUR VAN DE GEZONDHEIDSZORG}

Als bëlangrijkste kenmerken van de organisatiestruktuur worden hieronder vergeleken de echelonnering en de bestuurlijke indeling van de gezondheidszorg. In Engeland en Zweden zijn overeenkomstige echelons te onderscheiden als in Nederland. De gang van een patiënt volgend, zijn te onderscheiden in Nederland: de eerstelijnsof wijkgezondheidszorg, die in Engeland zijn equivalent vindt in de primary care en community care en in Zweden in de oppen vård (open zorg).

De poliklinische zorg van algemene ziekenhuizen in Nederland is te vergelijken met de OPD (Out-Patient-Department)-care in Engeland. In Zweden valt deze zorg onder de open zorg. De intramurale instellingen zijn in elk van de drie landen in te delen naar acute, academische en psychiatrische ziekenhuizen, verpleeghuizen en zwakzinnigeninrichtingen. Binnen de kategorie acute ziekenhuizen wordt in Zweden en Engeland een verdere echelonnering (klassificatie van de funkties) aangehouden. Te onderscheiden zijn in Zweden het districts-, landstings- en het regio-ziekenhuis. In Engeland wordt het District General Hospital onderscheiden als belangrijkste ziekenhuis in een health district naast allerlei kleinere "cottage"-hospitals. In Nederland wordt voor algemene, acute ziekenhuizen geen echelonnering gehanteerd. Wel is het zo, dat de grotere ziekenhuizen meestal ook een groter aktiviteitenpakket aanbieden (zie voor uitvoeriger bespreking van de echelonnering par. 2.2., 4.2. en 5.2.).

De echelonnering vormt in Engeland en Zweden een nationaal kader, waarbinnen de regio-besturen moeten werken. Het formuleren van dit kader zal vanwege de overzichtelijkheid in Nederland ook op nationaal niveau moeten plaatsvinden. Dit houdt 
in, dat de regionale beleidsruimte in ieder geval moet uitgaan van een dergelijk echelonneringskader.

In elk van de drie landen werken zelfstandig gevestigde (particuliere) artsen. In Engeland bestaat de private practice binnen en buiten de NHS-instellingen. Ook is te wijzen op de zelfstandige positie van de independent contractors in de eerstelijnszorg, te weten de huisarts, tandarts, apotheker en opticien. In Zweden worden in de open zorg particuliere praktijken gevoerd. In Nederland zijn huisarts en specialist in het algemeen zelfstandig gevestigd. Uit de aanwezigheid van zelfstandig gevestigde artsen in elk van de drie landen moet worden verwacht, dat deze in enigerlei vorm tot in lengte van jaren ook in Nederland zullen funktioneren. Dit houdt in, dat een regionale struktuur alleen bestaansmogelijkheden heeft, indien ze hiermee rekening houdt.

De bestuurlijke indeling van de gezondheidszorg ontwikkelt zich sinds 1950 in Engeland en Zweden van een indeling naar te verlenen zorg naar een regionale indeling. In Engeland ontstaat uit een "bewildering variety of agencies" eerst de "tripartite structure", met eigen bestuursorganen voor de community care, de family practitioners en de intramurale instellingen. In de jaren zestig wordt deze driedeling als belemmerend beschouwd voor een integraal beleid, waama in 1974 een regionale bestuurlijke indeling volgt (zie par. 2.2., 2.4.4. en 3.2.). In Zweden komen in 1951 de zorg voor chronische patiënten, in 1963 de open zorg en in 1967 de psychiatrische ziekenhuizen onder de bestuurlijke verantwoordelijkheid van de landstingen. Op deze wijze wordt getracht de integratie van gezondheidszorg tot stand te brengen (zie par. 4.2.).

In Nederland worden de meeste werkeenheden òf bestuurd door een eigen rechtspersoon, gevormd vanuit het particulier initiatief, ò gevormd door voor eigen rekening werkende beroepsbeoefenaren.

Deze werkeenheden worden gecoördineerd en in hun bestuurlijke vrijheid beperkt door een aantal nationale organen (zie uitvoerig par. 5.2.). Het regionalisatieproces is er in een beginstadium (zie par. 1.1.). De invoering van regionale strukturen blijkt in Engeland en Zweden een ontwikkelingsproces te zijn. Dit proces is te zien als het doen van kleine stappen, waarbij het einddoel wel in algemene termen is geformuleerd. Uit de dissertatie van Van der Werff (101) blijkt dat in alle westerse landen het gezondheidszorgbeleid op deze wijze wordt gerealiseerd. In Engeland werd gepoogd de regionalisatie per 1 april 1974 niet als een ontwikkelingsproces tot stand te brengen. Er werd gewerkt met blauwdrukken en voorschriften, die achteraf niet goed blijken te passen op de praktijk. Dit heeft ertoe geleid, dat twee jaar na de reorganisatie een Royal Commission alle relaties moet evalueren en de struktuur nu wèl geleidelijk aan bijgesteld lijkt te gaan worden.

Het ontwikkelingsproces is in Engeland en Zweden niet beëindigd: er worden subregio's gevormd in Zweden. Er worden in Engeland plannen per clientengroep ontwikkeld. Samenwerkingsprojecten met de maatschappelijke dienstverlening worden in beide landen opgezet. In Zweden zijn in 1972 maatregelen genomen ter bevordering van de samenwerking tussen de eerstelijnszorg en de intramurale instellingen. Uit de interviews van dit onderzoek blijkt verder, dat niemand terug wil naar de oude strukturen.

Ook in Nederland zal de regionalisatie als een ontwikkelingsproces moeten worden gezien. Een dergelijk invoeringsproces zal vele jaren duren, zoals blijkt uit de ervaringen in Engeland en Zweden. Het is de vraag, of een dergelijk proces ooit zal stoppen. Verwacht moet worden, dat nieuwe zorgbehoeften onder de bevolking ook steeds andere strukturen binnen een regio zullen vereisen.

Tenslotte is over de regionale struktuur het volgende op te merken. De relaties tus- 
sen de medische professie en het management van de gezondheidszorg zijn in beide landen in de jaren zestig gereorganiseerd. In Engeland werden de reeds genoemde Cogwheel-Committees gevormd (zie par. 3.2.). In Zweden kwam in 1970 de zevenkronen-hervorming tot stand. Deze hervormingen hangen samen met de vorming van de regionale strukturen, maar kwamen niet tegelijkertijd ermee tot stand (zie par. 3.2., 4.2.1. en 4.4.1.).

Thans worden in Engeland vanuit de medische professie twee - in teaching districts drie - afgevaardigden in het District Management Team gekozen. Verder bestaat er een op wettelijke grondslag gebaseerd stelsel van medische adviesorganen, de Cogwheel-Committees. In Zweden hebben medici de totale verantwoordelijkheid voor de verschillende "blokken" (zie par. 3.2., 4.2.1. en 4.4.1.). Wil in Nederland de regionalisatie een goede kans van slagen hebben, dan zal een redelijke mate van instemming ermee van de kant van de medische professie noodzakelijk zijn. Deze instemming is mogelijk, zo lijken de ervaringen in Engeland en Zweden te leren, indien ook een redelijke mate van invloed in de organisatiestruktuur gewaarborgd blijft. In tabel 6.3. worden de verschillende kenmerken van de organisatiestrukturen samengevat.

Tabel 6.3. Organisatiestruktuur van de overheid en van de gezondheidszorg in Engeland, Zweden en Nederland

\begin{tabular}{|c|c|c|c|}
\hline & Engeland & Zweden & Nederland \\
\hline Parlementaire democratie & ja & ja & ja \\
\hline $\begin{array}{l}\text { Scheiding beleidstormulering en beleids- } \\
\text { uitvoering }\end{array}$ & neen & ja & neen \\
\hline Belastinggebied lagere overheid & kleiner & groter & kleiner \\
\hline Rearganisatie binnenlands bestuur gelijk- & & & \\
\hline $\begin{array}{l}\text { tijdig met regionalisatie gezondheidszorg } \\
\text { Regionale verantwoordelijkheid voor ge- }\end{array}$ & ja & ja & $\mathrm{ja}^{1}$ \\
\hline zondheidszorg en maatschappelijke dienst- & & & \\
\hline $\begin{array}{l}\text { verlening bij één regionaal orgaan } \\
\text { Spanningsveld tussen centrale overheids- }\end{array}$ & neen & neen & $\mathrm{ja}^{1}$ \\
\hline organen en werkeenheden & ja & ja & ja \\
\hline Aantal bestuurslagen voor gezondheidszorg & 4 & 3 & $3^{2}$ \\
\hline Aanwezigheid wijkgezondheidszorg & ja & ja, samen- & ja \\
\hline Aanwezigheid ziekenhuispoliklinieken & $\mathrm{ja}$ & gevoegd & ja \\
\hline $\begin{array}{l}\text { Aanwezigheid funktieklassificatie zieken- } \\
\text { huizen binnen nationaal kader }\end{array}$ & ja & ja & $j a^{1}$ \\
\hline $\begin{array}{l}\text { Aanwezigheid zelfstandig gevestigde artsen } \\
\text { Ontwikkeling regionale indeling van de ge- } \\
\text { zondheidszorg vanuit een indeling naar }\end{array}$ & ja & ja & ja \\
\hline $\begin{array}{l}\text { zorgsoort } \\
\text { Participatie medische professie in regionale }\end{array}$ & ja & ja & $\mathrm{ja}^{1}$ \\
\hline organisatiestruktuur & ja & ja & $\mathrm{ja}^{1}$ \\
\hline
\end{tabular}

Bron: Zie paragraaf 6.2.3. en 6.3.

${ }^{1}$ Uitwerking in deze studie van de regionale organisatiestruktuur. 


\subsection{BESLUITVORMING OVER AKTIVITEITEN EN CAPACITEITEN}

In de formele besluitvormingsstruktuur worden vijf soorten besluiten onderscheiden, te weten over achtereenvolgens aktiviteiten, arbeidsplaatsen, kapitaalgoederen, organisatiestruktuur en financiële middelen. De vorming van de eerste vier besluiten komt hieronder aan de orde op achtereenvolgens het arts-patiënt en instellingsniveau (par. 6.4.1.), het regionaal niveau (par. 6.4.2.) en het nationaal niveau (par. 6.4.3.). Per paragraaf worden eerst de drie landen vergeleken. Daarna volgt een beschrijving van deze besluitvorming binnen een regionale organisatiestruktuur in $\mathrm{Ne}$ derland. Deze beschrijving is van globale aard, aangezien deze studie zich concentreert op het financieringsstelsel.

\subsubsection{Arts-patiënt- en instellingsniveau}

De besluitvorming over de zorgverlening aan een individuele patiënt vindt in elk van de drie landen zowel in 1950 als in 1975 plaats tussen de behandelende arts en de individuele patiënt.

De aktiviteiten, de beschikbare financiële middelen, het aantal arbeidsplaatsen en de beschikbare kapitaalgoederen van de werkeenheden in een regio worden in 1950 in elk van de drie landen hetzij door de werkeenheid zelf, hetzij in overleg met deze door diverse regionale en nationale instanties vastgesteld (voor een beschrijving van deze instanties en de bijbehorende werkeenheden zij verwezen naar de paragrafen 2.3., 4.3. en 5.3.). In 1975 worden de meeste van deze besluiten - zie voor de uitzonderingen de desbetreffende paragrafen - in Engeland en Zweden genomen door één regionale instantie en wel door het DMT en de landsting. In Nederland vindt in dat jaar de besluitvorming plaats als in 1950, waarbij de normering door de nationale instantie wel stringenter is geworden.

Beshiten over de organisatiestruktuur binnen een regio worden in 1950 in Engeland en Zweden door verschillende autonome instanties en in 1975 hoofdzakelijk op nationaal en regionaal niveau genomen. In beide jaren wordt in Nederland de beslissing over het aantal werkeenheden in een regio genomen door de nationale instanties. De overige beslissingen worden er op eigen initiatief van de werkeenheden genomen (zie voor een beschrijving par. 2.3.3., 3.3.3., 4.3.3. en 5.3.3.).

Beschouwen we de hierboven beschreven Engelse en Zweedse besluitvorming in het licht van een mogelijke regionale organisatiestruktuur in Nederland, dan komt onderstaand beeld naar boven. De besluitvorming ten aanzien van de behandeling diagnose - en therapievaststelling en doorverwijzing - van de individuele patiënt blijft berusten bij de individuele arts en patiënt. Het kader van de behandeling wordt gevormd door de aan de arts beschikbaar gestelde infrastruktuur, te weten de apparatuur, de behandelruimte en de personele assistentie. Over de omvang van deze infrastruktuur wordt door de werkeenheid beslist. Andere besluiten die de werkeenheid neemt betreffen de interne gang van zaken en de belangenbehartiging naar buiten. Voor het aktiviteitenpakket, het maximum aantal arbeidsplaatsen (waaronder medici), en voor de omvang van investeringen in gebouwen en apparatuur behoeft ze toestemming van het regionaal bestuur. Binnen deze kaders heeft ze de ruimte voor het voeren van een eigen beleid ten aanzien van de behandeling en verzorging van kategorieën patiënten, van de personeelswerving en van de keuze van apparatuur.

\subsubsection{Het regionale niveau}

Het aktiviteitenaanbod, het aantal arbeidsplaatsen, de investeringsruimte en de organisatiestruktuur van een regio worden in 1950 in de drie landen opgebouwd vanuit 
de beslissingen die genomen worden hierover ten aanzien van de werkeenheden. In 1975 worden in Engeland en Zweden wel dergelijke beslissingen genomen ten aanzien van een regio. Deze beslissingen vormen dan een kader voor de te nemen besluiten over de werkeenheden. Deze regionale besluiten worden in Engeland voor de health districts genomen door de AHA, voor de AHA's door de RHA, en voor deze laatste door het DHSS. In Zweden worden deze regionale besluiten door de landsting genomen binnen de kaders van de Socialstyrelsen (zie voor een beschrijving met uitzonderingen de paragrafen 2.3., 3.3., 4.3. en 5.3.). De nieuwe Engelse en Zweedse organisatiestruktuur is voorafgegaan aan de regionale planning van het aktiviteitenpakket en de capaciteit van de instellingen in een regio. Thans is de korte, middellange en lange termijnplanning van het aktiviteitenpakket en de capaciteit per instelling ondergebracht bij één regionaal bestuur. De planning voor de korte termijn wordt afgeleid uit die voor de middellange termijn. Deze laatste is op zijn beurt gebaseerd op de planning voor de lange termijn. De voorbereiding en besluitvorming van deze plannen berust in Engeland en $Z$ weden bij het regionale bestuur zelf. Een dergelijke konstruktie wordt in beide landen gezien als een voorwaarde voor één regionaal beleid. Deze zienswijze is in overeenstemming met de bevindingen van Vincente Navarro, die de planning van de gezondheidszorg in Zweden in het begin van de jaren zeventig heeft onderzocht. Hij geeft aan, dat de kracht van de planning zo groot is omdat ze wordt uitgevoerd door het management zelf: " $\mathrm{P}_{\mathrm{e}}-\mathrm{P}_{\mathrm{o}}=0$, i.e. planning $\left(\mathrm{P}_{\mathrm{e}}\right)$ without power $\left(\mathrm{P}_{\mathrm{o}}\right)$ equals zero" (Navarro, 288, p. 139).

Bij het plannen werken de regionale besturen in Engeland en $\mathrm{Zweden}$ binnen nationale kaders, die hun beslissingsruimte aangeven. In de volgende subparagraaf komen deze kaders nader aan de orde.

Op grond van de vergelijking met Engeland en Zweden wordt hier gepleit om de besluitvorming over het aktiviteitenpakket en de capaciteit per instelling te leggen bij één regionaal bestuur. Dit bestuur is dan verantwoordelijk voor het vaststellen van korte, middellange en lange termijnplannen, die onderling samenhangen. Bij de besluitvorming over deze plannen werkt het regionale bestuur met nationale kaders, die de beslissingsruimte aangeven (zie par. 6.4.3.). De vraag, wie op welke wijze bij de totstandkoming van de regionale plannen betrokken moeten worden, valt buiten de opzet van deze studie. Wil een plan evenwel gedragen worden door de verschillende professionele groepen en instellingen, dan zullen deze toch een redelijke mate van invloed op de planvorming moeten hebben. Met deze kanttekening wordt binnen het kader van deze studie volstaan.

\subsubsection{Het nationale niveau}

In Engeland en Zweden worden op nationaal niveau ten aanzien van de aktiviteitenpakketten en de capaciteiten de volgende nationale beslissingen genomen (zie par. 3.3.1.en 4.3.1.).

\section{Aktiviteitenpakket}

1: Het goedkeuren van het lange termijnplan van de RHA door het DHSS (Engeland). Op basis hiervan stelt de RHA de AHA-plannen vast, en de AHA de districtsplannen.

2. Het beoordelen van het lange termijnplan van de landsting door de Socialstyrelsen (Zweden).

3. Het vaststellen van de echelonnering van funkties (funktieklassificatie) van ziekenhuizen. Door deze echelonnering wordt onder andere bepaald, in welk soort ziekenhuizen topklinische funkties kunnen worden uitgeoefend (Engeland en Zweden). 
4. Het vaststellen van de maximale groei per specialisme van arbeidsplaatsen voor medici (in Zweden en in Engeland alleen voor medisch specialisten).

5. Het vaststellen van richtlijnen voor een vestigingsbeleid van huisartsen (in Engeland).

6. Het onderhandelen met vakbonden over primaire en secundaire arbeidsvoorwaarden (in Engeland en Zweden).

\section{Kapitaalgoederen}

7. Het aangeven van richtlijnen voor de gewenste capaciteit per 1000 inwoners in de RHA van een aantal voorzieningen (Engeland).

8. Het hanteren van een plafond per RHA voor nieuwe investeringen (in Engeland).

9. Het hanteren van bouwnormen voor nieuw te bouwen werkeenheden (in Engeland en Zweden).

\section{Organisatiestruktuur}

10. Het vaststellen van de samenstelling van de regionale bestuursorganen (in Engeland).

11. Het vaststellen van richtlijnen voor de organisatiestruktuur (in Engeland) en een aantal besluitvormingsprocedures (in Engeland en Zweden).

De meeste van deze beslissingen - behalve nr. 9 - gelden voor de regio als totaal. Het regio-bestuur stelt op basis hiervan kaders vast voor de afzonderlijke werkeenheden. Overwegingen om bovenstaande beslissingen op nationaal niveau te nemen zijn de gewenste rechtsgelijkheid voor alle regio's (bijvoorbeeld ten aanzien van besluit nr. 1, 2 en 6) en de benodigde deskundigheid (bijvoorbeeld nr. 3 en 9).

In Engeland en Zweden gelden de meeste van deze beslissingen - behalve besluit $\mathrm{nr}$. $1,2,4$ en 8 - op een uniforme wijze voor alle regio's. De resterende besluiten die de planning van aktiviteitenpakketten en capaciteiten betreffen, houden rekening met aanwezige regionale verschillen. Deze besluiten zijn specifiek ten aanzien van een bepaalde regio.

In Nederland vindt thans de besluitvorming over aktiviteitenpakketten en capaciteiten plaats op nationaal en werkeenheidsniveau. Voor het uitoefenen van een aantal topklinische funkties, het uitbreiden van het aantal specialismen, en het doen van investeringen boven de $f 500.000$ heeft een intramurale instelling thans toestemming nodig van een instantie op nationaal niveau. Voor de overige instellingen geldt dat voor verandering en uitbreiding van het aktiviteitenpakket en de capaciteit in het algemeen toestemming nodig is van de financier (zie uitgebreid par. 5.3.1.). Voor de meeste instellingen geldt, dat op nationaal niveau richtlijnen worden aangegeven van de gewenste capaciteit per 1000 inwoners. Op dit niveau vinden ook onderhandelingen plaats over de arbeidsvoorwaarden.

Een regionale besluitvormingsstruktuur in Nederland lijkt een overeenkomstige nationale besluitvorming te vereisen als in Engeland en Zweden. Ten opzichte van de bestaande situatie in Nederland betekent dit de volgende veranderingen in de besluitvorming. Op nationaal niveau worden vooral beslissingen genomen ten aanzien van een regio en niet ten aanzien van een individuele werkeenheid. Alleen bouwnormen voor instellingen worden op nationaal niveau vastgesteld in verband met de hiervoor gewenste deskundigheid. Als beslissingen, die tot nu toe niet op nationaal niveau worden genomen, zijn te noemen:

a. de goedkeuring van de regionale plannen

b. het vaststellen van het echelonneringskader 
c. het aantal arbeidsplaatsen in de regio van huisartsen en van medisch specialisten per specialisme

d. het vaststellen van een bouwplafond per regio

e. het vaststellen van richtlijnen voor de organisatiestruktuur en de besluitvormingsprocedures binnen een regio

Beslissingen b. en e. zijn hierbij gedacht als uniform en algemeen geldend voor alle regio's. Besluiten a., c. en d. zijn specifiek voor de verschillende regio's. Ze houden rekening met aanwezige, regionale verschillen. Wel kunnen ze erop gericht zijn deze verschillen geleidelijk te verminderen. De vraag, welke instanties op nationaal niveau bij een regionale organisatiestruktuur in Nederland moeten funktioneren, valt buiten het bestek van dit onderzoek. In Nederland bestaan op dit moment verschillende nationale instanties, die besluiten nemen dan wel daartoe adviseren. Te noemen zijn de Ministeries van Volksgezondheid en Milieuhygiëne, van CRM, van Financiën, van Onderwijs en Wetenschappen, de Centrale Raad voor de Volksgezondheid, de Gezondheidsraad, de Ziekenfondsraad, het College voor Ziekenhuisvoorzieningen en het Centraal Orgaan Ziekenhuistarieven. Hoezeer de organisatie van de besluitvorming op nationaal niveau thans ook ter discussie staat (CRV, 29, Ziekenfondsraad, 112 en $K N M G, 62$ ), wij moeten hier volstaan met de opmerking, dat de per regio te hanteren kaders op elkaar èn op die van de maatschappelijke dienstverlening afgestemd moeten zijn. Indien een zekere consistentie afwezig is, leidt dit tot grote fricties.

\subsection{HET FINANCIERINGSSTELSEL}

Hieronder wordt het financieringsstelsel besproken op achtereenvolgens arts-patiënten instellingsniveau (par. 6.5.1.), op regionaal niveau (par. 6.5.2.) en op nationaal niveau (par. 6.5.3.). In een aparte subparagraaf wordt ingegaan op de specifieke aspekten van de financiering van investeringen (par. 6.5.4.). In paragraaf 6.5.5. worden de voorwaarden samengevat waaraan het financieringsstelsel in een regionale organisatiestruktuur moet voldoen.

In Nederland vindt de financiering thans vooral plaats vanuit sociale verzekerings(ziekenfonds- en AWBZ-)premies. In Engeland en Zweden gebeurt dit vooral uit belastingpremies. Toch is dit verschil minder groot dan het lijkt.

Ten eerste wordt in Nederland de overheidsbemoeienis met de premies van de sociale verzekeringen groter. Hierdoor wordt het verschil tussen deze premies en de belastingtarieven geringer. De verzekeringspremies krijgen dan het karakter van "geoormerkte" financiële rijksmiddelen. In wezen zijn deze dan niet meer te onderscheiden van de Engelse geoormerkte DHSS-gelden, die aan de NHS-instanties worden toegewezen. Ten tweede wordt in 1975 in Engeland $10 \%$ en in Zweden 18\% van de gezondheidszorg betaald uit de sociale verzekeringen. In principe is een regionale struktuur kennelijk te combineren met het karakter van een financiering uit sociale verzekeringen.

Op grond van deze overwegingen (en het derde uitgangspunt in de probleemstelling van deze studie) wordt hier gepleit om ook in de toekomst de gezondheidszorg voornamelijk te financieren via een stelsel van sociale verzekeringen. Het handhaven van deze financieringswijze leidt tot minder veranderingen dan een omzetting van de premies in rijks- of regionale belastingen.

\subsubsection{Arts-patiënt- en instellingsniveau}

De extramurale gezondheidszorg wordt in elk van de drie landen deels op basis van 
tarieven en deels op basis van budgetten gefinancierd. In Engeland en Nederland kennen huisartsen, tandartsen, apothekers en andere voor eigen rekening werkende beroepsbeoefenaren een tariefstelsel (zie par. 2.3., 3.3.2.2. en 5.3.2.). In Zweden bestaat een dergelijk stelsel voor alle aktiviteiten van de open zorg. De hulpverleners zijn hier in loondienst: de inkomsten uit tarieven worden er ontvangen door de landstingen. In Engeland en Nederland worden instellingen voor de maatschappelijke gezondheidszorg en andere extramurale instellingen gefinancierd op basis van budgetten. In $Z$ weden vallen deze onder de regelingen van de hierboven genoemde open zorg. In Engeland en Zweden betalen patiënten voor verschillende vormen van de extramurale zorg een eigen bijdrage. In Nederland is dat alleen het geval voor particuliere patiënten en met betrekking tot fondspatiënten voor zorgverlening, die niet in het ziekenfondspakket is opgenomen.

In Engeland en Zweden kennen de intramurale instellingen een stelsel van budgetfinanciering. In beide landen stelt het regionale bestuur het budget vast en de financièle middelen beschikbaar. Het budget wordt er gezien als een onderdeel van de operationele en strategische planning. De medisch specialisten van de instellingen kennen een dienstverband bij het regionale bestuur (zie uitvoerig par. 3.3.1. en 4.3.2.). In Nederland worden de intramurale instellingen en medisch specialisten gefinancierd op basis van tariefstelsels. De kosten van de instellingen worden beoordeeld door het $\mathrm{COZ}$. Op basis hiervan worden de tarieven voor fondsverzekerden vastgesteld door de Ziekenfondsraad en de particuliere tarieven door het $\mathrm{COZ}$ zelf. De tarieven van de voor eigen rekening werkende specialisten behoeven goedkeuring van het Ministerie van Economische Zaken (zie par. 5.3.2.).

In elk van de drie landen berust de beslissing over de behandeling van de individuele patiënt bij de individuele arts en de individuele patiënt. Dit is ook het geval, indien de intramurale instelling een budgetfinanciering en de arts een dienstverband kennen. Dat zowel een tariefstelsel als een stelsel van budgetfinanciering te combineren zijn met vrijheid van medisch handelen is als volgt te verklaren.

Voor zijn werk heeft een arts zowel een infrastruktuur als middelen nodig. Bij de infrastruktuur is te denken aan medewerkers, apparatuur en praktijkruimte. De middelen betreffen medicijnen, medische gassen, verband en dergelijke. De infrastruktuur is intermitterend of discontinu variabel met de aktiviteitenomvang van de arts: voorbij een bepaalde kritische aktiviteitenomvang is uitbreiding nodig. De middelen zijn continu variabel met de aktiviteitenomvang. Grafiek 6.5.1. geeft de relatie aan tussen aktiviteitenomvang en de infrastruktuur en de middelen. Bij het benaderen van aktiviteitenomvang $\mathrm{A}, \mathrm{B}$ en $\mathrm{C}$ moet de discontinu variabele infrastruktuur aanzienlijk toenemen, bijvoorbeeld met een nieuwe medewerker of met nieuwe apparatuur (lijn II).

De continu variabele middelen nemen bij elke wijziging van de aktiviteitenomvang toe of af (lijn MM). Voor een wijziging van de discontinu variabele infrastruktuur moet de Engelse en $Z$ weedse arts een geargumenteerde aanvrage indienen bij een hogere instantie. Deze honoreert de aanvrage al dan niet. Dit geldt formeel ook voor een verandering in de middelenomvang, doch hier is de toestemming automatisch aanwezig (zie par. 2.3. en 4.3.). Deze procedures maken in Engeland en Zweden een budgetfinanciering mogelijk zonder een direkte normering van de aktiviteitenomvang. Afhankelijk van de organisatie van de infrastruktuur, de te behandelen patiënten en de te kiezen behandelmethoden kan in deze landen de aktiviteitenomvang per specialist bij vergelijkbare infrastruktuur aanzienlijk verschillen.

In Nederland geldt voor de medisch specialist in principe dezelfde relatie tussen de aktiviteitenomvang en de infrastruktuur. Aangezien zowel het ziekenhuis als de specialist per verrichting worden gehonoreerd, is voor een wijziging van de discontinue 
Grafiek 6.5.1. Relatie infrastruktuur, middelen en aktiviteitenontwikkeling van de individuele arts

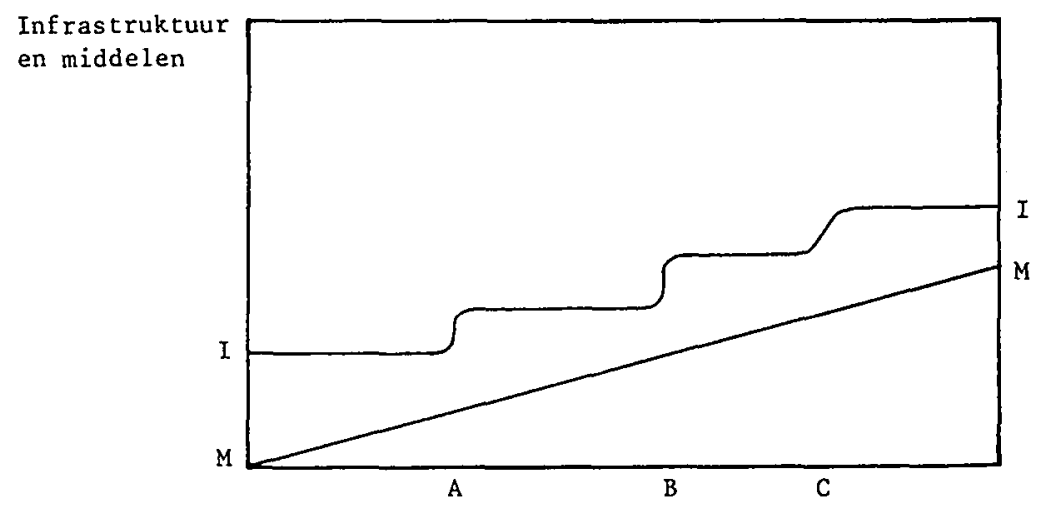

infrastruktuur ten gevolge van aktiviteitengroei in het algemeen geen toestemming nodig. Alleen voor nieuwbouw en verbouw van het ziekenhuis en voor aanschaf van zeer kostbare apparatuur is toestemming nodig (zie par. 5.3.).

Beschouwen we het toekomstige financieringsstelsel op arts-patiënt- en instellingsniveau tegen de achtergrond van de uitgangspunten in de probleemstelling van deze studie, dan komt voor Nederland het volgende beeld naar voren. De beslissingen ten aanzien van de zorgverlening aan de individuele patiënt blijven bij de individuele arts en patiënt berusten. De beslissing over de discontinu variabele medische infrastruktuur komt echter te liggen op het werkeenheidsniveau. Over het gebruik van medische middelen, medicijnen en andere continu variabele infrastruktuur beslist de arts. Essentieel hierbij is, dat een grotere aktiviteitenomvang van de arts niet automatisch leidt tot meer financiële middelen voor de discontinu variabele infrastruktuur. Het tariefstelsel voor huisartsen en specialisten kan hierbij grotendeels intakt blijven. Alleen zouden uit de artsenhonoraria de componenten, die als kostenvergoedingen voor de discontinue infrastruktuur zijn te beschouwen, moeten verdwijnen. Een dergelijke ontwikkeling is reeds aan de gang. Voor de huisarts en andere vrije beroepsbeoefenaren betekent dit, dat bij de tariefvaststelling een maximumbedrag wordt aangehouden voor de discontinu variabele infrastruktuur. Voor huisartsen bestaat reeds een hierop lijkende regeling bij fondsverzekerden, te weten de kostenknikregeling. Voorbij een praktijkgrootte van 1800 fondsverzekerden worden in het tarief geen bestanddelen opgenomen ter vergoeding van de vaste kosten van de infrastruktuur. De infrastruktuur van een medisch specialist in een instelling zou in de toekomst volledig gefinancierd moeten worden via de instelling. Deze wordt dan geconfronteerd met een taakstellende of gesloten begroting voor de infrastruktuur: overschrijdingen op dergelijke begrotingen worden slechts toegestaan na toestemming van de regionale of nationale instantie. Sankties op ongeoorloofde overschrijdingen kunnen bestaan uit het verplichten om een jaar later compenserende maatregelen te treffen. Ook is een extra-controle denkbaar. Uitgaven boven een bepaald bedrag moeten dan worden gefiatteerd door een externe instantie. Overschrijdingen op de open begrotingen voor de discontinu variabele middelen zijn wel toegestaan en worden in de begrotingen van het volgende jaar verrekend. Te ver- 
wachten is, dat de open budgetten geringer in omvang zullen zijn dan de gesloten budgetten. Deze verwachting is gebaseerd op een econometrische analyse van Van Aert en Van Montfort, die berekenden, dat de marginale kosten van een extra opname en een extra verpleegdag "ongeveer $25 \%$ of aanzienlijk minder" bedragen (3).

Een regionaal ontvangkantoor van financiële middelen en een stelsel van budgetfinanciering zijn hierbij niet noodzakelijk. Essentieel in de Engelse en Zweedse praktijk is het feit, dat de toegewezen financiële middelen een maximaal normerend karakter hebben. De feitelijke bestedingen mogen deze budgetten niet overschrijden. Dit nu is ook mogelijk bij een tariefstelsel op basis van taakstellende begrotingen voor de kosten: extra inkomsten boven de normstelling moeten dan worden afgetrokken van de inkomsten in het volgende jaar. Tekorten ten gevolge van te weinig aktiviteiten worden dan gecompenseerd in de inkomsten van het volgende jaar. In hoeverre budgetfinanciering toch de voorkeur verdient boven een tariefstelsel, wordt in dit geval een technische kwestie, waarbij voor- en nadelen van kosten van declareren en overige administratie bij beide stelsels moeten worden afgewogen. Ten aanzien van de begroting van de instellingen is essentieel, dat deze in de toekomst wordt beoordeeld door het regionale bestuur op samenhangen met de operationele en strategische plannen. In deze optiek is de begroting een onderdeel van het operationele plan, waarin voor de komende drie à vier jaar behalve de financiële middelen, ook het aktiviteitenpakket, de arbeidsplaatsen en de apparatuuromvang worden begroot. In verband met de hoeveelheid werk van de beoordeling van de begrotingen door de regionale instantie wordt in Engeland en $Z$ weden volstaan met het beoordelen van veranderingen, die ten opzichte van de bestaande situatie worden gepland. Deze veranderingen kunnen betreffen verhoging van financiële middelen, uitbreiding van arbeidsplaatsen, vervanging van medewerkers en vervanging en uitbreiding van apparatuur. Om deze beoordeling mogelijk te maken worden in Engeland en Zweden in de begroting van de instellingen deze veranderingen apart vermeld. Een dergelijke begrotingsmethodiek zal, gelet op de Engelse en Zweedse ervaringen (zie par. 3.4.1. en 4.3.2.) ook voor Nederlandse instellingen ingevoerd moeten worden. Indien dan het regionale bestuur zeggenschap krijgt over deze veranderingen heeft ze ook invloed op de richting van de geldstromen. Door zeggenschap over alle aspekten van de jaarbegroting van een werkeenheid zal haar invloed verder kunnen toenemen. Aangezien in Engeland en Zweden de funktieveranderingen op regionaal niveau de grootste aandacht krijgen, lijkt de eerste, beperkte, beoordeling voldoende om aansluiting mogelijk te maken met de operationele en strategische planning. De verdere beoordeling kan dan vallen onder de verantwoordelijkheid van de nationale instantie(s).

\subsubsection{Het regionale niveau}

In Engeland en $Z$ weden ontvangen de regionale autoriteiten financiële middelen, die ze daarna beschikbaar stellen aan de werkeenheden. In Engeland vindt na 1974 de fiñanciering vân de RHA's plaats uit rijksmiddelen op basis van indices, die de "re: latieve gezondheidsbehoeftèn" aangeven. De AHA's en de districts worden soms op basî́ văn overeenkomstige indices, soms op basis van de capaciteit gefinancierd (zie uitvoerig par. 3.3.2.2.). De belangrijkste inkomsten van de $Z$ weedse landstingen betreffen eigen belastingen (zie par. 4.3.2.). In Nederland worden de werkeenheden slechts voor een gering deel via of door regionale instanties (lokale overheden) gefinancierd (zie par. 5.3.2.).

In de toekomst zijn voor de positie van Nederlandse regionale instanties in het financieringsstelsel drie modellen mogelijk. Ten eerste is het mogelijk, dat de regio's uit één fonds hun financiële middelen verwerven. Hierbij wordt een financiering op basis van relatieve behoeften, zoals in Engeland, mogelijk. Eén Volksverzekering te- 
gen ziektekosten is hierbij noodzakelijk. Dit is te noemen het Engelse model.

Ten tweede is het mogelijk, dat de regionale instanties de financiële middelen ontvangen uit verschillende bronnen en daarna op basis van budgetten beschikbaar stellen aan de werkeenheden. Dit is het Zweedse model. De Zweedse landstingen ontvangen financiële middelen uit achtereenvolgens eigen belastingen, rijksbijdragen, patiëntenbijdragen en sociale verzekeringen. De werkeenheden worden hieruit op basis van budgetten gefinancierd.

In het derde model beoordeelt de regionale instantie de begrotingen alleen op de wijze, die hierboven is aangegeven. Ze adviseert de nationale instantie omtrent de mate, waarin de begroting van de instelling past in de operationele en strategische plannen. De nationale instantie stelt de begroting - en daarmee eventueel te hanteren tarieven - vast. Dit derde model wordt hier het regio-adviesmodel genoemd.

Gelet op het derde uitgangspunt van de probleemstelling wordt hier gekozen voor het derde model. Dit laat de bestaande geldstromen ongemoeid in tegenstelling tot de andere modellen.

Een andere reden om te kiezen voor dit model is de mogelijkheid van aansluiting bij de in de Ontwerp-Kaderwet Specifiek Welzijn voorgestelde en gedeeltelijk reeds ingevoerde Rijksbijdrageregelingen voor het welzijnswerk (Van der Dussen, 40, Van Eupen, 42, Knelpuntennota, 61 en Ministerie van CRM, 67). In hoeverre de Engelse en Zweedse modellen zich op lange termijn ontwikkelen is dan nog te bezien. Overigens is het mogelijk, dat bepaalde werkeenheden of onderdelen ervan wel op middellange termijn via de regionale instantie worden gefinancierd. De door het rijk gefinancierde werkeenheden komen hiervoor in aanmerking. Verder is te denken aan instellingen, die krachtens de AWBZ, een volksverzekering, worden gefinancierd. Ook voor gecentraliseerde ondersteunende diensten van intramurale instellingen, zoals een administratiekantoor, een bouwbureau of een opleidingsinstituut is een financiering via de regionale instantie mogelijk. In hoofdstuk 7 zal hier nader op in worden gegaan. De begroting van een instelling wordt, zoals gezegd, gezien als een onderdeel van de planningscyclus. Dit houdt in dat de nationale normen voor de begrotingen van instellingen in een regio afgeleid moeten worden uit de normen voor de vastgestelde regionale - operationele en strategische plannen. Als dit niet het geval is, ontstaan frikties. Zo ontstonden in Londen grote moeilijkheden, toen volgens de RAWP-voorstellen de RHA's in deze stad moesten bezuinigen, maar wel met behoud van de academische ziekenhuizen (zie par. 3.4.1.). De integratie van de begrotingen in de operationele en strategische plannen houdt ook in, dat de richtlijnen voor elk van de drie op overeenkomstige wijze rekening houden met regionale verschillen in capaciteit en met regiogrensoverschrijdend patiëntenverkeer.

In Engeland wordt door een financiering op basis van relatieve gezondheidsbehoeften getracht een verkleining van regionale verschillen na te streven. Deze financiering krijgt echter door correcties voor regiogrensoverschrijdend patiëntenverkeer en door de gestelde maxima en minima voor regionale veranderingen toch ook het karakter van een financiering op basis van aanwezige capaciteit (zie par. 4.4.3.). Het verkleinen van de verschillen gebeurt langzaam. Dit komt door het feit, dat mensen en gebouwen zich niet gemakkelijk laten verplaatsen van de ene naar de andere regio. Het verkleinen van regionale verschillen zal ook in Nederland een zaak van lange adem zijn. Vanwege deze beperkte mogelijkheden voor veranderingen lijkt het, dat de financiering van de exploitatiekosten van de kapitaalintensievere voorzieningen - meestal intramurale werkeenheden - hoofdzakelijk zal uitgaan van de aanwezige capaciteit. Wel kan een jaarlijkse bepaling van de regionale verschillen op basis van een formule voor relatieve behoefte plaatsvinden. De RAWP-formule kan als uitgangspunt dienen om een dergelijke formule te ontwikkelen. De resultaten van 
een dergelijke jaarlijkse meting kunnen dan bij het vaststellen van de plannen voor de verschillende periodes worden betrokken. De minder kapitaalintensieve - meestal extramurale instellingen - kunnen wel reeds op basis van relatieve gezondheidsbehoefte worden gefinancierd, waarbij dan via een gedifferentieerde groei voor de verschillende regio's naar overeenkomstige zorgniveau's kan worden toegewerkt.

Uitgaande van het regio-adviesmodel komt de vraag naar voren, welke betekenis een regionaal advies kan hebben voor de beslissende nationale instantie. Indien de nationale richtlijnen ter vaststelling van de begroting worden geformuleerd per kategorieinstelling, is een adviesruimte voor de regionale instantie afwezig. De bestaande COZ-normering voor intramurale instellingen wordt dan in wezen gecontinueerd. Indien de richtlijnen per groep gelijksoortige instellingen in een regio worden geformuleerd, is deze ruimte wel aanwezig. Een voorbeeld kan dit verduidelijken: indien als richtlijn wordt geformuleerd, dat de kosten van verpleegkundig personeel in elk verpleeghuis met $x \%$ mogen toenemen, dan is er geen ruimte voor een regionaal advies. Indien de richtlijn wordt verruimd tot: "in het komend jaar mogen de kosten van de funktie verpleeghuisopnamen in een regio met $x \%$ groeien", dan heeft het regiobestuur de vrijheid te letten op funktie-toenamen. Het kan dan adviseren dit percentage gedifferentieerd door te geven aan de individuele verpleeghuizen. Indien de richtlijn luidt: "de verplegingskosten van personen, die niet in staat zijn hun algemene, dagelijkse leven (ADL-)verrichtingen uit te voeren, mogen met x\% groeien", dan heeft een regio-bestuur meer adviesruimte. Het kan dan adviseren uit de toe te wijzen middelen zowel mantelzorg, wijkverpleging, centra voor dagverpleging als de verpleeghuisfunktie te stimuleren.

Een dergelijke ruimte-omschrijving levert een financiering op per cliëntengroep, die te vergelijken is met die in de RAWP-formule in Engeland en de Rijksbijdrageregeling voor het welzijnswerk in Nederland. Deze levert in Engeland de mogelijkheid voor het stichten van verschillende types werkeenheden. Voor Nederland lijkt het financieringsstelsel dit ook te kunnen bieden, indien de omschrijving voor de erkenningsnormen van werkeenheden door de nationale instanties meer wordt geformuleerd in zorgbehoeften van patiënten dan in kenmerken van de instelling zelf. De regionale instantie kan dan adviseren welke instellingen gefinancierd moeten worden binnen de nationale richtlijnen.

\subsubsection{Het nationale niveau}

In Engeland wordt jaarlijks door de regering en het parlement beslist hoeveel financiele middelen aan de NHS ter beschikking worden gesteld. De begroting van het DHSS wordt hierbij afgewogen tegen die van andere departementen (zie par. 2.4.2., 3.4.2.). In Zweden heeft de nationale overheid een geringe invloed op de jaarlijks beschikbaar gestelde financiële middelen. De landstingen stellen zelfstandig hun telastingtarieven vast, op basis waarvan zij het grootste deel van hun inkomsten verwerven (zie par. 4.4.2.).

In Nederland zijn de bestedingen voor de gezondheidszorg tot voor kort buiten de prioriteitstelling gebleven van de regering en het parlement. Gefinancierd via het stelsel van sociale verzekeringen werden bestedingen aan gezondheidszorg in geringe mate afgewogen tegen die van andere sektoren (par. 5.4.1.). Sinds kort is dat in toenemende mate het geval. De hoogte van de premies van de sociale verzekeringen en van de tarieven in de gezondheidszorg worden betrokken in het financiële beleid van de rijksoverheid. Op basis van de vergelijking van de drie landen wordt hier gepleit voor het vaststellen door de regering en het parlement van de financiële groeiruimte van de gezondheidszorg. Bestedingen voor gezondheidszorg kunnen dan op democratische wijze worden afgewogen tegen andere - collectieve en particuliere - 
aanwendingen van het BNP. Behalve door een beleid ten aanzien van de verzekeringspremies wordt een afweging ook mogelijk door de in paragraaf 6.5.1. bepleite invoering van gesloten budgetten voor de instellingen. Deze heeft als gevolg dat een groot deel van de kosten voor het Ziekenfonds en de AFBZ ook bestaat uit vaste budgetten. Open budgetten blijven alleen bestaan voor die kosten van de instellingen, die continu variëren met de medische aktiviteiten, zoals kosten van medicijnen, protheses en medische middelen. Ook in Engeland worden de kosten hiervoor gefinancierd via open budgetten: ze vallen zelfs buiten de cash-limits (zie par. 2.1.1.). Indien de hoogte van de verzekeringsgelden voor een groot deel als gesloten budget wordt vastgesteld, zijn hiervoor op nationaal niveau algemene kaders aan te geven voor de toegestane groei of absolute hoogte van deze budgetten gedurende een bepaalde periode. Uit deze kaders kunnen dan nationale groeikriteria worden afgeleid voor de verschillende soorten zorg, zoals ook reeds op indicatieve basis gebeurt in ramingen van het Ministerie van V \& M (69). Deze groeiruimten kunnen worden doorgegeven aan de regio-besturen, die op basis hiervan de begrotingen van de werkeenheden beoordelen.

Schematisch levert dit proces het volgende beeld op:

\section{Grafiek 6.5.3. Verdeling financiële ruimte van de gezondheidszorg}

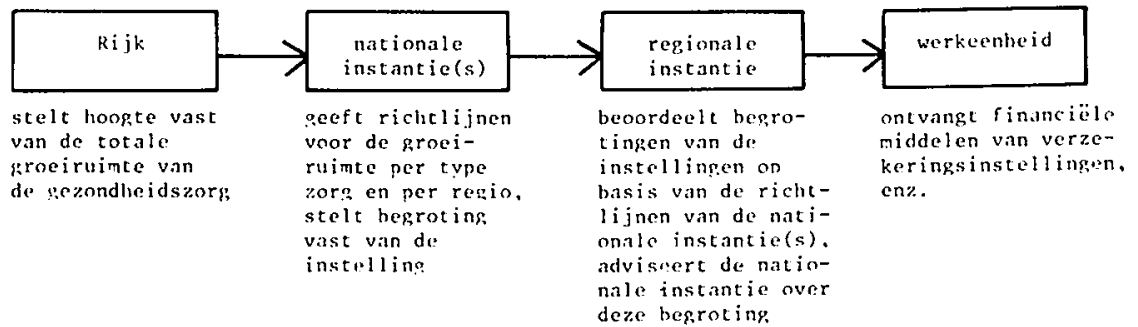

De samenhang van het strategische en operationele planningsproces en het financieringsproces ziet er dan voor de verschillende niveau's als volgt uit: de regionale instantie stelt haar aktiviteitenpakket op voor de strategische planning (ca. 10 jaar), waarin de aktiviteiten naar soort en omvang zijn opgenomen. Tevens worden capaciteitenveranderingen en nieuwe investeringen van de regio aangegeven. Op nationaal niveau wordt dit plan vastgesteld als onderdeel van een totaal plan. Voor de operationele termijn - vier jaar - werken het regiobestuur en de werkeenheden dit plan uit. Aktiviteitenpakketten worden door de werkeenheid voorbereid en door het regiobestuur vastgesteld. Aangegeven wordt hoe de investeringsruimte van de regio per instelling wordt verdeeld (zie par. 6.5.4.). Dit middellange termijnplan wordt door de nationale instantie getoetst aan het lange termijnplan en de middellange termijnverwachting van de nationale economische groeimogelijkheid, zoals door het rijk vastgesteld. De werkeenheid bereidt de jaarbegroting voor, die door het regiobestuur in het licht van het goedgekeurde middellange termijnplan wordt beoordeeld. Hierna wordt de jaarbegroting op grond van dit oordeel en tegen de achtergrond van de economische groeimogelijkheid op korte termijn door de nationale instantie(s) vastgesteld. 
6.5.4. Financiering van investeringen

In Engeland worden de investeringen gefinancierd met financiële middelen, die aan RHA beschikbaar zijn gesteld op basis van kriteria die de relatieve gezondheidstoestand van de bevolking en de omvang en de kwaliteit van de kapitaalgoederen aangeven. De investeringen binnen de RHA worden bepaald op grond van de strategische en operationele plannen. In Zweden zijn investeringen volledig een regionale aangelegenheid. Er bestaat geen bouwplafond per regio. In Nederland wordt over de investeringen op nationaal niveau beslist. Op grond van de uitgangspunten van de probleemstelling en de ervaringen in Engeland en Zweden wordt hier de opneming bepleit van de investeringsplanning in de strategische en operationele planning. Hierdoor is een integratie van de drie mogelijk. Als één van de richtlijnen voor deze plannen zou voor een regio moeten worden aangegeven welke de beschikbare investeringsruimte per kategorie-instelling is. Deze ruimte is te berekenen op basis van een formule, waarin de relatieve gezondheidszorgbehoeften in de regio en de kwaliteit en omvang van de kapitaalgoederenvoorraad statistisch worden gewogen. De Engelse RAWP-formule is hierbij als voorbeeld te gebruiken.

6.5.5. Samenvatting van de voorwaarden voor een financieringsstelsel in een regionale organisatiestruktuur

In de vorige subparagrafen is getracht een antwoord te formuleren op de probleemstelling van deze studie. Samengevat worden de volgende voorwaarden voor een financieringsstelsel van een geregionaliseerde gezondheidszorg genoemd:

1. het aangeven van het maximum van de kosten van de infrastruktuur van een voor eigen rekening werkende beroepsbeoefenaar in de extramurale gezondheidszorg, dat in de tarieven mag worden doorberekend (par. 6.5.1.).

2 . het vervangen van vergoedingen uit het specialistenhonorarium voor de kosten van de infrastruktuur van een medisch specialist in een instelling door een financiering uit de inkomsten van de instelling (par. 6.5.1.).

3 . het hanteren van een taakstellend of gesloten budget voor de infrastruktuur en een open budget voor de middelen van een instelling (par. 6.5.1.).

4. het koppelen van de jaarlijkse begroting van instellingen aan regionale, operationele en strategische plannen (par. 6.5.1.).

5 . het invoeren van een stelsel van gedifferentieerd begroten door de instelling, waarbij de kosten van wijzigingen in aktiviteitenpakket, personeelsbezetting, apparatuur en huisvesting duidelijk naar voren komen (par. 6.5.1.).

6. het opstellen van regionale adviezen over de wijzigingen sub 3. aan de nationale instantie, die de tarieven van instellingen vaststelt (par. 6.5.2.).

7. het vervangen van de subsidies van het rijk aan instellingen door rijksbijdragen aan regionale besturen en regionale subsidies aan deze instellingen (par. 6.5.2.).

8. het aangeven door het rijk van de gewenste financiële groei van de infrastruktuur per regio en per zorgsoort (par. 6.5.3.).

9. de opneming van de investeringsplanning in de operationele en strategische planning van de regio (par. 6.5.4.).

10. het hanteren van een financieel bouwplafond voor investeringen per regio en per kategorie instelling (par. 6.5.4.).

\subsection{DOELSTELLINGEN GEZONDHEIDSZORG}

In deze paragraaf gaat het om de vraag, of een financieringsstelsel, dat voldoet aan de voorwaarden hierboven, aan het gezondheidszorgbeleid in positieve zin kan bij- 
dragen. De in deze studie onderscheiden doelstellingen worden hieronder per subparagraaf besproken. Geïnventariseerd en vergeleken wordt, in welke mate ze in elk van de drie landen worden verwezenlijkt. Voor de drie landen wordt daarna geanalyseerd, wat de invloed van het financieringsstelsel op het beleid is. Op basis van deze analyse wordt bekeken, welke invloed te verwachten is van het in de vorige paragraaf besproken stelsel.

\subsubsection{Niveau en kwaliteit handhaven}

In tabel 6.6.1. worden enige kwantitatieve gegevens over de aktiviteiten van de verschillende landen met elkaar vergeleken. Dit wordt gedaan met enige aarzeling, omdat soms onder gelijkluidende begrippen toch andere zaken worden verstaan. Met name de begripsafbakening tussen "gezondheidszorg" en "maatschappelijke dienstverlening", tussen de verschillende kategorieën intramurale instellingen onderling en tussen de laatste en bejaardenoorden is niet steeds dezelfde. Met deze kanttekening is bij de aktiviteitenontwikkeling per 1000 inwoners van de drie landen het volgende op te merken. (Alle opmerkingen en gegevens in deze paragraaf zijn gebaseerd op de uitgebreidere tekst van de paragrafen 2.4.1., 3.4.1., 4.4.1.en 5.4.1.).

- Het aantal huisartsen is in 1950 en 1975 in Engeland hoger dan in Nederland en Zweden. In de twee eerste landen stijgt dit aantal niet. In Zweden stijgt het aantal districtsartsen. Het aantal wijkverpleegkundigen is in 1950 in de drie landen op vergelijkbaar niveau. In 1975 is dit aantal in Engeland driemaal zo hoog als in Zweden en 2,5 maal zo hoog als in Nederland.

- In 1950 is het aantal poliklinische consulten in Engeland en Zweden op vergelijkbare hoogte. In 1974-1975 is dat het geval voor Zweden en Nederland. De Zweedse groei is aanmerkelijk groter dan de Engelse.

- In 1950 waren er in de drie landen ongeveer evenveel medisch specialisten werkzaam per 1000 inwoners. In 1975 is dat nog het geval voor Engeland en Nederland (0,60 resp. 0,53 specialist per 1000 inwoners). In Zweden werkt in 1975 één medisch specialist per 1000 inwoners.

- Het aantal ziekenhuisopnamen is in 1950 en 1975 in Engeland en Nederland op vergelijkbare hoogte. In $Z$ weden is dit aantal in beide jaren hoger dan in deze landen. De gemiddelde ligduur komt in Engeland en Zweden overeen, maar is in Nederland langer dan in deze twee landen. Het aantal bedden in algemene ziekenhuizen daalt in Engeland en Zweden en stijgt in Nederland. In 1975 is dit aantal in Nederland en $Z$ weden op vergelijkbare hoogte $(5,8$ resp. 5,5$)$, terwijl Engeland uitkomt op 3,9.

- Het aantal bedden in psychiatrische ziekenhuizen daalt in Engeland en Zweden en is in 1975 op vergelijkbaar niveau $(3,4$ resp. 3,3). Nederland ligt in 1975 daaronder $(1,9)$. Het aantal bedden in zwakzinnigeninrichtingen vertoont in de drie landen in 1975 slechts geringe verschillen met dat in 1950 .

- Het aantal verpleeghuizen voor somatische zieken is van de drie landen het sterkste gegroeid in Zweden (1975: Zweden 4,9; Engeland, inclusief geriatrische verpleeghuizen, 1,2; en Nederland 2,0). Het lage aantal in Engeland hangt samen met het feit, dat over verpleeghuizen van de lokale overheid geen gegevens beschikbaar zijn. Indien daarmee rekening zou worden gehouden, zou het aantal bedden in de bovengenoemde instellingen tezamen in 1975 in Engeland en Nederland op een vergelijkbaar niveau kunnen liggen (nu 8,5 resp. 12,2). In Zweden ligt dit aantal zowel in 1950 als in 1975 hierboven $(14,0$ resp. 16,8).

- Het aantal arbeidskrachten, werkzaam in de gezondheidszorg, is in 1950 in de drie landen op vergelijkbaar niveau (Engeland, 1949: 9,3; Zweden, 1950: 11,5 
Tabel 6.6.1. Ontwikkeling aktiviteiten van de Engelse, Zweedse en Nederlandse gezondheidszorg $1950-1975$ per 1000 inwoners

\begin{tabular}{|c|c|c|c|c|}
\hline & & Engeland & Zweden & Nederland \\
\hline $\begin{array}{l}\text { Aantal huisartsen } \\
\text { Aantal wijkverpleegkundigen } \\
\text { Aantal poliklinische consulten in al- } \\
\text { gemene ziekenhuizen } \\
\text { Aantal medisch specialisten } \\
\text { Aantal opnamen in algemene zieken- } \\
\text { huizen } \\
\text { Gemiddelde ligduur in algemene zie- } \\
\text { kenhuizen in dagen } \\
\text { Aantal bedden in algemene zieken- } \\
\text { huizen } \\
\text { Aantal bedden in psychiatrische zie- } \\
\text { kenhuizen } \\
\text { Aantal bedden in verpleeghuizen } \\
\text { voor somatische zieken } \\
\text { Aantal bedden in verpleeghuizen } \\
\text { voor demente bejaarden } \\
\text { Aantal bedden in zwakzinnigenin- } \\
\text { richtingen } \\
\text { Totaal aantal bedden in bovenstaan- } \\
\text { de instellingen } \\
\text { Aantal arbeidskrachten werkzaam in } \\
\text { de gezondheidszorg }\end{array}$ & $\begin{array}{l}1950 \\
1975 \\
1950 \\
1975 \\
1950 \\
1975 \\
1950 \\
1975 \\
1950 \\
1975 \\
1950 \\
1975 \\
1950 \\
1975 \\
1950 \\
1975 \\
1950 \\
1975 \\
1950 \\
1975 \\
1950 \\
1975 \\
1950 \\
1975 \\
1950 \\
1975\end{array}$ & $\begin{array}{c}0,51^{3} \\
0,46^{2} \\
0,23^{1} \\
0,60^{2} \\
602,4^{1} \\
679,8^{2} \\
0,29^{1} \\
0,55^{2} \\
65,9^{1} \\
103,5^{2} \\
15,5^{1} \\
10,4^{2} \\
4,8^{1} \\
3,9^{2} \\
4,4^{1} 14 \\
2,2^{2} \\
1,2^{10} \\
1,2^{2} 10 \\
3 \\
2^{2} \\
1 \\
1,2^{2} \\
10,4^{10} \\
8,5 \\
9,3^{1} \\
15,2^{2}\end{array}$ & $\begin{array}{c}0,1^{4} \\
0,2^{4} \\
0,2 \\
0,2 \\
590 \\
1190^{2} \\
0,3 \\
1,0^{2} \\
116,3 \\
158,1 \\
15,8 \\
9,9 \\
7,0^{15} \\
5,8^{15} \\
3,5^{15} \\
3,3^{15} \\
1,3^{15} \\
4,9^{15} \\
0,6^{15} \\
1,2^{15} \\
1,6^{15} \\
1,6^{15} \\
14,0 \\
16,8 \\
11,5 \\
24,6^{5}\end{array}$ & $\begin{array}{c}0,36 \\
0,36 \\
0,20^{8} \\
0,27 \\
-\quad \\
1090 \\
0,20^{9} \\
0,53 \\
50,3^{11} \\
105,3 \\
21,7 \\
16,1 \\
3,6^{12} \\
5,5 \\
2,5^{13} \\
1,9 \\
0,6 \\
2,0 \\
0,1 \\
0,9 \\
0,4^{13} \\
1,9 \\
7,0 \\
12,2 \\
7,8^{7} \\
17,8\end{array}$ \\
\hline
\end{tabular}

Bron: zie tabellen 2.4.1., 4.4.1. en 5.4.1.

11949.

21974.

31959.

4 Districtsartsen.

51973.

$? 1947$.

8 1951, exclusief Oranje-Groene Kruis.

- Eigen schatting op basis van aantal huisartsen in 1950 en artsen in 1970.

10 Inclusief verpleeghuisbedden voor demente bejaarden.

11 Exclusief militaire ziekenhuizen en sanatoria.

121951.

13 Bezette bedden.

34 Inclusief bedden in zwakzinnigeninrichtingen.

15 De $Z$ weedse indeling volgt niet het type ziekenhuis maar het type zorg: Psychiatrische bedden in een algemeen ziekenhuis worden bijvoorbeeld gerekend onder psychiatrische ziekenhuizen. 
en Nederland, 1947: 7,8). Weliswaar vertonen de betreffende gegevens voor 1949, 1950 en 1947 onderlinge verschillen, maar deze zullen voor Engeland (1949) en Nederland (1947) in 1950 dichter bij dat van Zweden liggen. In 1975 is het aantal arbeidskrachten in Engeland en Nederland op vergelijkbare hoogte. In Zweden ligt het boven het niveau van deze twee landen.

Uit bovenstaande ontwikkelingen komt naar voren, dat de Nederlandse gezondheidszorg in een aantal opzichten lijkt op de Engelse en in een aantal andere opzichten op de Zweedse gezondheidszorg. Met Engeland komen overeen de aantallen medisch specialisten, ziekenhuisopnamen, totaal aantal in intramurale instellingen aanwezige bedden en het totaal aantal arbeidskrachten, werkzaam in de gezondheidszorg. Met Zweden zijn vergelijkbaar de aantallen wijkverpleegkundigen, poliklinische consulten en bedden in algemene ziekenhuizen. Nederland neemt een tussenpositie in ten aanzien van het aantal huisartsen en vertoont de langste ligduur in algemene ziekenhuizen. Gemeenschappelijk in de drie landen is de aktiviteitengroei in de algemene ziekenhuizen (poliklinische consulten en aantal opnamen) en de groei van het totaal aantal arbeidskrachten in de gezondheidszorg werkzaam.

Over de gemiddelde omvang van de intramurale instellingen is het volgende op te merken. In Engeland neemt de gemiddelde omvang van ziekenhuizen inclusief verpleeghuizen toe van 122 naar 142 bedden. Van de overige instellingen daalt de omvang van 637 naar 395 bedden. De gemiddelde omvang van alle Zweedse intramurale instellingen steeg van 100 bedden in 1950 naar 155 bedden in $1975.19 \%$ (156) van alle 809 instellingen neemt tweederde (64\%) van het totaal aantal verpleegdagen voor zijn rekening. In Nederland neemt de omvang van de algemene ziekenhuizen toe van 173 bedden in 1950 tot 300 bedden in 1975. Die van de overige instellingen varieert in dat laatste jaar van 130 (verpleeghuizen) tot 363 (psychiatrische ziekenhuizen).

In Engeland en Nederland is het beleid erop gericht het niveau van de voorzieningen van algemene ziekenhuizen te verlagen. Hoewel in beide landen emaar gestreefd wordt de eerstelijnszorg te versterken, ligt in het eerste land toch ook een accent op de versterking van de zorg voor chronische patiënten. Deze zorg met name vindt vaak plaats in verouderde gebouwen. In Zweden komt uit de lange termijnplannen het beeld naar voren van het handhaven van het bestaande niveau aan ziekenhuisvoorzieningen en het versterken van het niveau van voorzieningen voor de open zorg en de chronische patiënten. In Engeland en Zweden worden deze lange termijndoelen omgezet via de jaarbegroting in een geleidelijke aanpassing van het aktiviteitenpakket en de capaciteiten van de instellingen.

De toegankelijkheid van de zorgverlening laat in elk van de drie landen in bepaalde sektoren te wensen over. Deze sektor is in Zweden de open zorg, in Engeland de niet-acute ziekenhuisopnamen en in Nederland enkele topklinische funkties, zoals open hart-chirurgie. Voor deze sektoren bestaan in deze landen wachtlijsten.

Financiële eigen bijdragen van patiënten worden in Engeland gehanteerd voor het gebruik van medicijnen en dergelijke. In Zweden bestaan deze bijdragen voor de open zorg en het verblijf in het ziekenhuis. In Nederland gelden eigen bijdragen voor particuliere verzekerden. Voor fondsverzekerden is dit alleen het geval voor verstrekkingen die buiten het verzekeringspakket vallen.

De ontwikkeling van de aktiviteiten wordt in de drie landen op overeenkomstige wijze verklaard. Gewezen wordt op de groei van het nationaal inkomen, ontwikkeling van het medisch kunnen, en op de vergrijzing van de bevolking (zie par. 2.4.1., 4.4.1. en 5.4.1.). In hoeverre de ontwikkelingen van de verschillende soorten werkeenheden elkaar hebben beinvloed, is in het kader van deze studie slechts globaal aan te geven. Zo lijkt de grote intramurale groei in Zweden samen te hangen met een gerin- 
gere groei in de eerste lijn. In Engeland hangt het relatief gering aantal algemene ziekenhuisbedden wellicht samen met het relatief grote aantal huisartsen en wijkverpleegkundigen en bedden in de overige intramurale instellingen. Een bijdrage aan de aktiviteitenontwikkeling kan het in paragraaf 6.5 . bepleite financieringsstelsel leveren door de koppeling van de begrotingen van de instellingen aan de regionale operationele en strategische plannen. Hierdoor wordt het mogelijk - zoals in Engeland en Zweden - jaarlijks in deze plannen passende veranderingen aan te brengen in het aktiviteitenpakket en de capaciteit van de instellingen in de regio.

\subsubsection{Afremming kostengroei}

Vanaf 1950 nemen de kosten in de drie landen toe (zie grafiek 6.6.2.1.). In Nederland zijn ze in 197625 maal zo hoog als in 1953. In het Verenigd Koninkrijk is sprake van een (bijna) vertienvoudiging in 1975 ten opzichte van 1950. De kosten in Zweden zijn in 1975 bijna twintigmaal zo hoog als in 1950. Vanaf 1968 stijgen de kosten in Nederland sterker dan in beide andere landen. Uitgedrukt als percentage van het BNP (zie grafiek 6.6.2.2.).

Liggen de kosten van Nederland en Zweden vanaf 1965 boven die van het Verenigd Koninkrijk (1975 Nederland, 8,8\%, Zweden, 7,6\% en VK 5,4\%). In 1965 is dit percentage in het Verenigd Koninkrijk vrijwel gelijk aan dat van 195i (1951:3,9\% en 1965: 4,1\%). In de beide andere landen groeit dit percentage ook in de periode vóór 1965.

De ontwikkeling van de totale kosten wordt in de drie landen op overeenkomstige wijze verklaard. In elk van de drie landen wordt gewezen op de faktoren aktiviteiten- en capaciteitengroei en op de inflatie (zie par. 2.4.2., 4.4.2. en 5.4.2.). De aktiviteiten-en capaciteitengroei is dan verder weer te verklaren uit de groei van het $\mathrm{BNP}$, medische ontwikkeling en de veroudering van de bevolking.

De relatie van het financieringsstelsel met aktiviteiten- en kostenontwikkeling is in de drie landen verschillend. In het Verenigd Koninkrijk wordt de gezondheidszorg vooral gefinancierd uit algemene rijksmiddelen, is ze onderdeel van het gehele overheidsbeleid en moet ze concurreren binnen het totale budget met andere takken van overheidszorg. Eén van de bevindingen van ons onderzoek in Engeland is, dat van dit laatste een remmende invloed uitgaat op de ontwikkeling van de gezondheidszorg. Deze relatie, bestaande uit een keten van budgetten vanaf de rijksbegroting tot aan het infrastrukturele budget van de arts, wordt aangegeven in paragraaf 3.4.2. In Zweden vindt de financiering vooral uit lokale belastingen plaats. Er is enige afweging tegen andere takken van overheidszorg. Deze afweging is echter gering, omdat het grootste deel van de bestedingen van de landstingen de gezondheidszorg betreffen. Verder zijn de landstingen ten opzichte van de rijksoverheid autonoom in het bepalen van het belastingtarief (zie par. 4.4.2.). In Nederland vindt de financiering vooral plaats uit specifiek voor de gezondheidszorg geheven (verzekerings)-premies. $\mathrm{Bij}$ de besteding van de premiegelden vindt geen afweging plaats met andere sektoren van overheidszorg. Verder worden de aktiviteiten per verrichting gehonoreerd. Onze bevinding voor Nederland was, dat deze struktuur de ontwikkeling van de gezondheidszorg heeft begunstigd (zie par. 5.4.2.4.).

Is de verschillende invloed van het financieringsstelsel nu in de kostenontwikkeling van de drie landen merkbaar? In studies die het vergelijken van de kostenontwikkeling van de gezondheidszorg van verschillende - westerse - landen tot onderwerp hebben, wordt het lage percentage in het BNP van het Verenigd Koninkrijk op twee manieren verklaard. Ofwel er wordt gewezen op de financiering uit overheidsmiddelen, waarbij een afweging plaatsvindt tegen andere overheidsbestedingen (Maxwell, 207). Anderen wijzen deze verklaring af (Ståhl, 304, OECD, 292 en Anderson, 122) 
Grafiek 6.6.2.1. Kosten van de gezondheidszorg in Zweden, Engeland (V.K.) en Nederland 1950-1975 (1970 = 100)

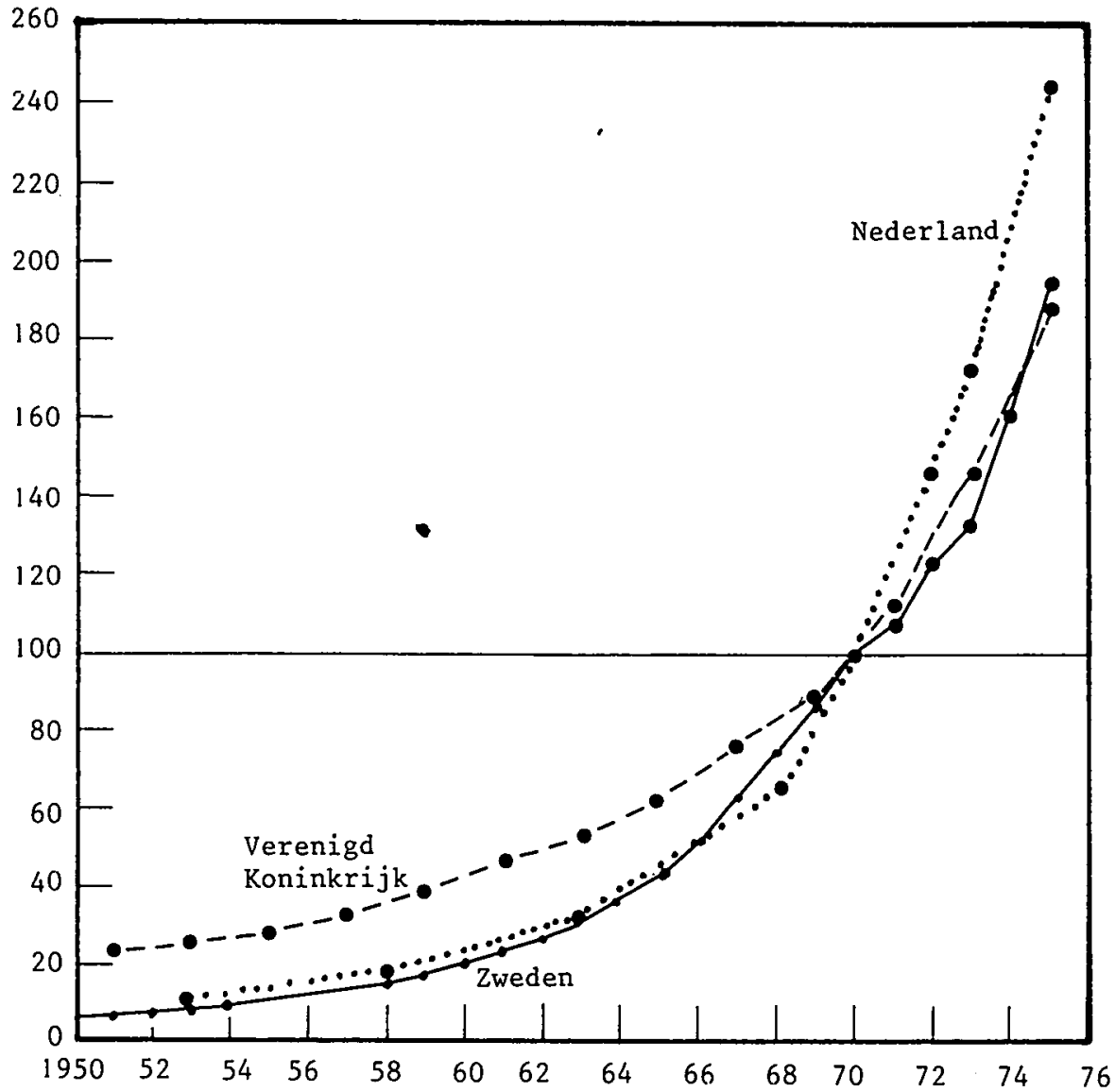

Bron: $\operatorname{SOS}(239,240$ en 241), CSO (132), DHSS (141), CBS (15).

en stellen dat het relatief lagere BNP per hoofd van de bevolking in Engeland de belangrijkste verklaring hiervan is. De OECD (77) geeft met behulp van een cross section analysis aan, dat in 1974 de verschillen in het BNP per.capita van 19 westerse landen voor bijna $90 \%$ de verschillen in het percentage van het BNP van de kosten van de gezondheidszorg kunnen verklaren.

Uit deze studie komt naar voren, dat beide faktoren in de drie landen de ontwikkeling van de kosten hebben beinvloed. Dit is af te leiden uit de bestudering van het financieringsstelsel: in elk van de drie landen leidt een groeiend BNP tot hogere belasting- en/of premie-inkomsten, waaruit nieuwe ontwikkelingen gefinancierd kunnen worden. Afhankelijk van het stelsel moeten deze nieuwe ontwikkelingen meer 
Grafiek 6.6.2.2. Kosten van de gezondheidszorg in Zweden, Engeland (V.K.) en Nederland, gemeten in \% van het B.N.P. tegen marktprijzen

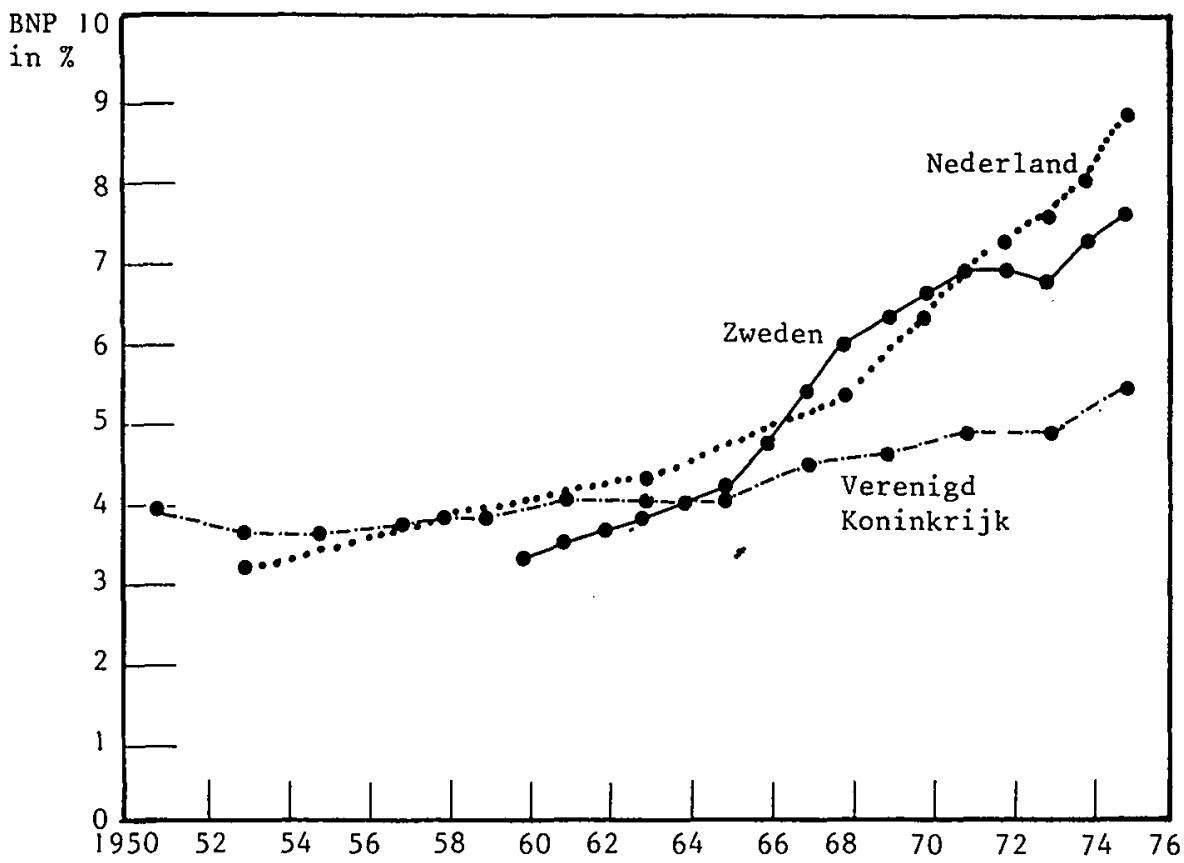

Bron: zie grafiek 6.6.2.1.

of minder concurreren met andere bestedingsmogelijkheden en wordt de kostenontwikkeling ervan meer of minder afgeremd. Dat alleen de besluitvormingsstruktuur van belang is lijkt onwaarschijnlijk: de voorbeelden uit Engeland, waarbij een tegenvallende economische groei rechtstreeks leidt tot een afremming van de bestedingen van de overheid (en het DHSS), zijn het bewijs van het tegendeel. Dat alleen de ontwikkeling van het BNP de verschillen in het percentage van het BNP van de kosten van de gezondheidszorg kan verklaren, is evenmin waarschijnlijk. Als dit zo zou zijn, dan zou dit percentage in Engeland over de periode 1950-1965 moeten stijgen, toen in Engeland het BNP bijna verdrievoudigde. Verder zou in Nederland dit percentage in de periode 1972-1975 beneden dat van Zweden moeten liggen, aangezien het BNP in Zweden boven dat van Nederland ligt. Bestudering van grafiek 6.6.2.2. levert echter op, dat noch voor Engeland, noch voor Nederland de bedoelde relaties opgaan.

Beschouwen we de aktiviteiten- en kostenontwikkeling van Engeland en Zweden in het licht van de mogelijke invloed van het in paragraaf 6.5. bepleite financieringsstelsel, dan is een afremming van de totale kosten te verwachten van de afweging op nationaal niveau van de kosten van de gezondheidszorg tegen die van andere bestedingskategorieën van het BNP. Verder is een afremming te verwachten van de regio- 
nale advisering over de instellingsbegrotingen. Deze advisering, als onderdeel van het totale planningsproces in de regio, kan doublures in aktiviteitenpakket en infrastruktuur voorkomen.

Er zijn weliswaar twee argumenten te noemen, die gelet op de afremming van de totale kosten, pleiten tegen de invoering van regionale besluitvormingsstrukturen, doch deze hoeven niet veel hout te snijden. Ter Heide wijst erop, dat er "achterstandsregio's" zullen ontstaan, die zullen streven naar het niveau van de regio's met de meeste voorzieningen (55). Dit is inderdaad gebeurd in Engeland na de reorganisatie van de NHS (zie par. 3.4.3.). Het streven van de welvoorziene regio's naar een verdere groei is er echter tegelijk afgeremd. In Engeland wordt door de RHA's het totaal van de beschikbare middelen voor de NHS geaccepteerd (zie par. 3.4.3.). Er vindt weinig coalitievorming plaats tussen de RHA's om meer middelen van het DHSS te verkrijgen vanwege de uiteenlopende belangen van de eerstgenoemden. Van een grotere groei van de NHS-kosten sinds 1 april 1974 is dan ook geen sprake (zie par. 3.4.2.). Het andere argument contra betreft de groei van de kosten van de regionale instantie zelf. Er zal per regio een apparaat moeten worden opgebouwd, dat groter zal zijn naarmate er meer besluiten moeten worden voorbereid, vastgesteld en uitgevoerd. In Engeland stegen inderdaad de managementskosten per regio na de reorganisatie. Door het DHSS werd daarom in 1975 de opdracht aan de RHA's gegeven te onderzoeken of deze met $10 \%$ konden worden verlaagd. Hierbij moest worden gekeken naar alle managementniveau's. Bij de opbouw van regionale besluitvormende instanties in Nederland zou op dezelfde wijze moeten worden bekeken, of dat management op nationaal en instellings-niveau tegelijkertijd kan worden beperkt.

In Engeland en Zweden hebben in de afgelopen 25 jaar verschillende financieringsstelsels naast elkaar bestaan. Hierdoor werd de ontwikkeling in sommige sektoren gestimuleerd dan wel afgeremd. Te wijzen is op het verband tussen de relatief grote groei van de academische ziekenhuizen in Engeland en de rechtstreekse financiering van deze door het DHSS (zie par. 2.4.2.). In Zweden is het achterblijven van de open zorg mede veroorzaakt door de financiering hiervan uit 's rijks middelen, terwijl de intramurale zorg gestimuleerd is door het eigen belastingsgebied van de landstingen. Hoewel één financieringsbron voor regionale besluitvorming van de gezondheidszorg in Nederland niet noodzakelijk is - zowel in Engeland als in Zweden is meer dan één bron aanwezig - blijkt uit bovengenoemde voorbeelden dat een eigen, autonome invloed van de afzonderlijke financieringsstelsels en financiers - ministers, verzekeringsinstellingen - kan leiden tot een onevenwichtige groei van de verschillende sektoren van de gezondheidszorg. Alleen een consistente besluitvorming op nationaal niveau, zoals bepleit in paragraaf 6.4.3. en 6.5.3. kan een dergelijke groei voorkomen.

\subsubsection{Evenwichtige geografische spreiding}

In elk van de drie landen bestaan gedurende de onderzochte periode regionale verschillen per inwoner in achtereenvolgens de aanwezige voorzieningen, het gebruik van deze voorzieningen door de regio-bevolking, het aantal artsen en de kosten. In Nederland en Zweden zijn in de jaren vijftig sommige regio's relatief ondervoorzien, die in 1975 overvoorzien zijn, terwijl ook het omgekeerde voorkomt. In Engeland bestaat in de jaren zeventig in grote lijnen hetzelfde beeld als in 1948. In Engeland werkte het "icing on the cake" principe, waardoor de historische patronen behouden bleven. In geen van de drie landen is er een effektief beleid gericht geweest op het verkleinen van regionale verschillen. Sinds 1970 wordt in Engeland wel een beleid gevoerd om deze verschillen te verminderen. Dit gebeurt door het toewijzen van 
financiële middelen op basis van een aantal indices. Geleidelijk aan nemen de verschillen hierdoor af (zie: Engeland, par. 2.4.3. en 3.4.3.;Zweden, par. 4.4.3. en Nederland, par. 5.4.3.).

Indien in Nederland de begroting wordt gehanteerd in samenhang met de operationele en strategische plannen, is een geleidelijk proces naar een evenwichtige geografische spreiding mogelijk. In de strategische plannen kunnen dan de streefcijfers worden opgenomen, waarmee bij het beoordelen van de begroting rekening wordt gehouden. Overigens lijkt dit proces gemakkelijker te kunnen verlopen indien de financiële middelen voor de gezondheidszorg toenemen. De ondervoorziene regio's kunnen dan groeien zonder dat de overvoorziene regio's inleveren.

\subsubsection{Integratie zorgverlening}

In Engeland is in de periode 1948-1974 sprake van een niet aaneengesloten gezondheidszorg. Dit feit wordt veroorzaakt door de "tripartite structure" van de NHS. De reorganisatie in 1974 beoogde een grotere samenhang te bewerkstelligen. Enkele jaren na 1974 lijkt dit effekt enerzijds te worden bereikt door de integrale planning en de nauwere relatie tussen de extra- en intramurale zorgverlening. Met name de kleinere instellingen lijken gebaat bij de regionale struktuur. Anderzijds zijn na de reorganisatie nieuwe desintegrerende verschijnselen ontstaan. Te noemen zijn het te grote aantal managementniveau's, een gebrek aan samenwerking met de maatschappelijke dienstverlening, en een tekort aan coördinatie binnen het ziekenhuis. Deze knelpunten leiden niet tot een wens terug te keren naar de oude situatie, maar tot een verdere geleidelijke verbetering van de organisatiestruktuur (zie par. 2.4.4. en 3.4.4.). In Zweden is in de jaren zestig vrijwel de gehele gezondheidszorg onder de verantwoordelijkheid gekomen van de landstingen. Thans is er sprake van een groeiende afstemming tussen de instellingen. De kleinere instellingen worden er door het regionale niveau ondersteund in hun beleidsvoering. Toch is er nog lang geen sprake van een ideale situatie. Het gebrek aan continu iteit met dezelfde hulpverlener wordt in Zweden als een groot probleem ervaren. De samenwerking met de maatschappelijke dienstverlening laat te wensen over. Ook in dit land wil niemand terug naar de oude situatie. Er wordt gewerkt aan een verdere ontwikkeling van de integratie, waarvoor de hervormingen in de jaren zestig een basis hebben gelegd (zie par. 4.4.4.). In Nederland ontbreken besluitvormingskaders ten aanzien van samenwerking tussen instellingen. Er is slechts samenwerking mogelijk, indien de betrokken instellingen, voor eigen rekening werkende beroepsbeoefenaren en instanties tot overeenstemming komen. Tot stand gebrachte regionale organen zijn niet in staat veranderingen te entameren zonder de bereidheid van de werkeenheden hiertoe te verwerven. De besluitvormingsstruktuur weerhoudt deze echter om zelf tot funktieverandering over te gaan. Het inhoud geven aan de versterking van de eerstelijnsgezondheidszorg en aan de gedachte van zorgketens verloopt hierdoor moeizaam. Kleine ziekenhuizen hebben moeite met hun voortbestaan, aangezien ze niet in staat zijn een aantal taken van hun organisatie te centraliseren (zie uitvoerig par. 5.4.4.). De samenwerking met de maatschappelijke dienstverlening laat eveneens te wensen over. In de paragrafen 6.2. en 6.3. is de regionalisatie van de organisatiestruktuur als uitgangspunt van de probleemstelling nader uitgewerkt. Er is uitgegaan van drie managementniveau's, waarvan één voor de instelling. Verder moet het gebied en bestuur van de regio's samenvallen met dat van de provincies c.q. grote steden, die ook regionale verantwoordelijkheid dragen voor de maatschappelijke dienstverlening. Door deze uitwerking kan een aantal ongunstige desintegrerende gevolgen van de nieuwe Engelse en Zweedse strukturen worden vermeden. Indien dan tevens gekozen wordt voor een geleidelijke ontwikkeling, is een tussentijds bijsturen mogelijk 
en kunnen de Engelse problemen worden voorkomen. Het financieringsstelsel levert een bijdrage aan de integratie doordat de jaarbegrotingen, als sluitstuk van de regionale planning, door de regionale besturen van een advies worden voorzien. De afstemming van aktiviteitenpakketten van verschillende instellingen kan hierdoor worden bevorderd.

\subsubsection{Vergroten betrokkenheid van patiënten en medewerkers}

\subsubsection{Satisfactie patiënten en medewerkers}

Voor Engeland komt, uit een enquête onder meer dan 10.000 patiënten in algemene ziekenhuizen, naar voren, dat $94 \%$ van de patiënten tevreden is over zijn verblijf aldaar. Bij patiënten in een psychiatrisch ziekenhuis ligt dat percentage op 54\% (zie par. 2.4.5.). Patiënten lijken weinig te hebben gemerkt van de reorganisatie: van honderd geinterviewde personen in Manchester wist slechts $10 \%$ dat er een reorganisatie had plaatsgevonden (zie par. 3.4.5.1.).

Uit een enquête onder 854 inwoners van de Zuidzweedse landsting antwoordt $44 \%$ van de geënquêteerden tevreden te zijn over de zorgverlening, $18 \%$ is neutraal, $9 \%$ is ontevreden en de overigen (29\%) hebben geen specifieke attitude. De meest geuite klachten betreffen het gebrek aan continuiteit en de lange wachttijden. Ten aanzien van het verblijf in het ziekenhuis zijn deze percentages $65 \%$ tevreden, $8 \%$ neutraal, $4 \%$ ontevreden en $23 \%$ zonder specifieke attitude (zie par. 4.4.5.1.).

Uit een onderzoek onder 700 ex-patiënten van Nederlandse ziekenhuizen blijkt een grote tevredenheid: $96 \%$ spreekt over vriendelijke en aardige artsen en verpleegkundigen; $88 \%$ heeft geen en slechts $9 \%$ heeft wel kritiek op de wijze van behandeling; $78 \%$ is van mening veel aandacht te hebben gekregen, terwijl $16 \%$ die mening niet is toegedaan.

De bovenstaande enquêtes zijn niet geheel vergelijkbaar, omdat de formulering van de vragen verschilde. Indien wij veronderstellen dat personen zonder specifieke attitude in de Engelse en Nederlandse onderzoeken vallen onder de kategorie "tevreden", liggen de percentages "tevreden + geen specifieke attitude" voor de algemene ziekenhuizen in elk van de drie landen op vergelijkbare hoogte (Engeland 94\%, Zweden $88 \%$, namelijk $65 \%+23 \%$ en Nederland $96 \%$ ). Wegens gebrek aan gegevens is ten aanzien van de overige zorgverlening geen vergelijking te maken. Een regionalisatie van de Nederlandse gezondheidszorg en veranderingen in het financieringsstelsel lijken mogelijk met behoud van een hoge satisfactie van patiënten. Gewaakt moet worden tegen het ontstaan van wachttijden en een gebrek aan continuiteit in de zorgverlening. Juist een regionalisatie als ontwikkelingsproces, zoals hiervoor bepleit, biedt de mogelijkheid hier tegen te waken.

\section{Satisfactie medewerkers}

In de afgelopen jaren is de arbeidsvreugde van de NHS-medewerkers in Engeland vooral beïnvloed door het reorganisatieproces, de algemene politieke en economische situatie en ten derde door de kwestie van de particuliere bedden. Met name bleven akties voortduren voor betere arbeidsvoorwaarden (zie par. 3.4.5.1.). De Zweedse medische professie lijkt tevreden met de bestaande organisatiestruktuur. Als knelpunten komen in Zweden het gebrek aan verpleegkundig personeel en de hoge direkte belastingen naar voren (zie par. 4.4.5.1.).

Over de arbeidssatisfactie van Nederlandse werknemers in de gezondheidszorg zijn geen landelijke onderzoekgegevens beschikbaar. De indruk komt naar voren, dat de werkbelasting stijgt. Met name het tekort aan verpleegkundigen in ziekenhuizen wordt in dit verband genoemd (zie par. 5.4.5.1.). Uit de ervaringen in Engeland en 
Zweden komt de indruk naar voren, dat een regionalisatie de satisfactie van medewerkers niet hoeft te beinvloeden, indien deze geleidelijk wordt uitgevoerd en de arbeidsvoorwaarden van medewerkers intakt laat. Bij een Nederlandse regionalisatie zal dan ook aan beide grote aandacht moeten worden besteed.

\subsubsection{Inspraak van patiënten en medewerkers}

Voorafgaande aan belangrijke besluiten moeten de gezondheidsautoriteiten in Engeland vele belangengroepen horen. In interviews met managers en medici komt onvrede hierover naar voren. Deze wordt veroorzaakt door onduidelijkheid over de plaats, waar beslissingen nu eigenlijk worden genomen. Ook de hoeveelheid werk, dat verbonden is aan de consultatierondes, speelt een rol bij het ontstaan van deze onvrede. De medische professie neemt via de Cogwheel-Committees deel aan de managementteams. De patiëntenraden (CHC's) hebben in Engeland als belangrijkste bevoegdheid tekst en uitleg over het gevoerde beleid te vragen aan de managementteams. Ook in Zweden worden uitgebreide consultatierondes gehouden, voordat belangrijke beslissingen worden genomen. Overleg en inspraak van medewerkers en instanties vieren er hoogtij. De medische professie neemt deel aan de besluitvorming zowel op regionaal niveau als binnen de instelling. De indruk komt naar voren, dat patiënten of hun vertegenwoordigers weinig betrokken worden bij de besluitvorming. Eens in de drie jaar kiezen de patiënten als inwoners het bestuur van hun landsting. Tussentijdse raadpleging van specifieke patiëntengroepen lijkt weinig voor te komen. De invloed van de politici lijkt gering, maar neemt wel toe. In Nederland is ten aanzien van de inspraak van medewerkers en belangengroepen gekozen voor breed samengestelde adviesorganen. In de verschillende landelijke adviesorganen zijn medewerkers, vakbonden, werkgevers, (lokale) overheden, instellingsbesturen, verzekeringsinstellingen in wisselende aantallen vertegenwoordigd.

Op regionaal niveau komen overeenkomstige organen voor zoals provinciale en gemeentelijke gezondheidsraden. Binnen de instelling vindt de inspraak onder andere plaats via de ondernemingsraad. Euvels van de breed samengestelde adviesorganen zijn doublures in de advisering voor de participanten in de adviesorganen en het ontbreken van unanimiteit in de advisering. Er bestaat bij de participanten in adviesorganen dan ook de behoefte zelfstandig met standpunten naar buiten te treden, hetgeen in wezen neerkomt op toch een gescheiden advisering. De inspraak van specifieke patiëntengroepen in de brede adviesorganen is afwezig.

De betekenis van de ervaringen in de drie landen voor een toekomstig regionalisatieproces in Nederland is van drieërlei aard. Ten eerste zal duidelijk moeten zijn, welk orgaan of welke personen welke beslissingen nemen dan wel daartoe adviseren. Ten tweede lijkt een gescheiden advisering van de belangengroepen aan het regiobestuur toch de voorkeur te verdienen boven de vorming van brede adviesorganen, waarin alle betrokken groepen gezamenlijk tot een advies moeten komen. Met name zal de invloed van de medische professie en van specifieke patiëntengroepen op de managementteams gewaarborgd moeten zijn. Ten derde lijkt het bij het opstellen van de regionale plannen en van de regionale adviezen ten aanzien van de instellingsbegrotingen onontkoombaar, dat zowel bij gescheiden als gemengde advisering veel overleg en inspraak noodzakelijk is. Hierbij zullen dan duidelijke inspraak-afspraken en inspraakprocedures moeten worden gehanteerd.

Als bijdrage van het financieringsstelsel in de nieuwe struktuur is te noemen de meningsvorming van de regionale besturen over de begrotingen, als verlengstuk van de regionale plannen. Hierdoor kunnen door de volksvertegenwoordigers in de regionale besturen de belangen worden behartigd van de regionale bevolking als geheel. 
6.6.6. Samenvatting van de bijdragen van het financieringsstelsel aan het bereiken van thans in Nederland geldende doelstellingen

In de voorafgaande subparagrafen worden de bijdragen van het in paragraaf 6.5 . bepleite financieringsstelsel besproken. In onderstaand schema (tabel 6.6.6.) worden deze bijdragen nog eens samengevat. Ten aanzien van de aard van deze bijdragen verwijzen wij terug naar de bij de formulering van de probleemstelling gemaakte opmerkingen in paragraaf 1.2 .

Tabel 6.6.6. Relaties doelstellingen gezondheidsbeleid en financieringsstelsel

Doelstelling

Handhaven niveau en kwaliteit

Afremming kostengroei

Evenwichtige geografische spreiding

In tegratie zorgverlening

Vergroten betrokkenheid van patiënten en medewerkers
Bijdrage van het financieringsstelsel

Bereiken lange termijndoelen door jaarlijkse veranderingen en aktiviteitenpakket en capaciteit van instellingen in een regio

- afremming kostengroei in het algemeen

- voorkòmen doublures in aktiviteitenpakketten van instellingen

Verkleinen op lange termijn van regionale verschillen

Bevorderen afstemming van aktiviteitenpakketten van instellingen

Belangen behartiging van de bevolking van een regio door volksvertegenwoordigers
Deel van het financieringsstelsel dat bijdrage levert

Koppeling begrotingen aan operationele en strategische plannen

- afweging op nationaal niveau van bestedingen voor gezondheidszorg tegen andere bestedingsmogelijkheden van het BNP

- advisering door regiobestuur over begrotingen

- toewijzen regionale bouwplafonds en regionale groeiruimten

- koppeling begrotingen aan strategische plannen

Advisering door regiobestuur over begrotingen

Advisering door regiobestuur over begrotingen 


\section{NABESCHOUWING}

Wie tien voorwaarden formuleert voor een financieringsstelsel van een geregionaliseerde gezondheidszorg mag de kritiek verwachten een studeerkamergeleerde te zijn. De kritiek zou kunnen luiden: "Gesteld dat de voorwaarden juist en compleet zijn, dan tonen ze aan dat het bestaande financieringsstelsel met deze wijzigingen te combineren is met een regionalisatie van de Nederlandse gezondheidszorg. Gelet op het aantal en de aard van de hiervoor benodigde wijzigingen in het bestaande stelsel, tonen ze evenwel ook aan, dat een dergelijk stelsel voor de komende jaren in de praktijk onmogelijk is". Deze kritiek is op zichzelf terecht, maar onvolledig. In de vorige paragrafen is aangegeven, dat het invoeren van regionale strukturen een ontwikkelingsproces is. Dit geldt ook voor onderdelen daarvan, ook voor wijzigingen in het financieringsstelsel. Tegen deze achtergrond gezien is voor de praktijk in de komende jaren niet zo zeer van belang, of aan de bovengenoemde voorwaarden is te voldoen. De vraag, die veeleer gesteld moet worden, luidt: "Zijn er initiatieven mogelijk, waardoor, meer dan thans het geval is, aan deze voorwaarden kan worden voldaan". Er zijn reeds in Nederland initiatieven gaande in de richting van regionale strukturen. Te wijzen is op het Wetsontwerp Voorzieningen Gezondheidszorg en op de vorming van proefregio's. Voorstellen voor wijzigingen in het financieringsstelsel worden gedaan door de Centrale Raad voor de Volksgezondheid en de Ziekenfondsraad (zie par. 1.1.).

Deze ontwikkeling is te stimuleren door andere initiatieven, die hetzij een uitbreiding zijn van de bestaande, hetzij op andere gebieden liggen. In dit hoofdstuk wordt in paragraaf 7.1. een niet-uitputtende opsomming gegeven van dergelijke initiatieven die binnen enkele jaren mogelijk zijn. Deze initiatieven zijn niet getoetst op hun politieke haalbaarheid en niet uitgewerkt. Ze zijn tijdens het onderzoek als mogelijkheden naar voren gekomen. Aangezien de initiatieven betrekking hebben op de zeer korte termijn, worden de invoering van één volksverzekering tegen ziektekosten en de overgang naar een dienstverband van medisch specialisten hier niet genoemd. Eén volksverzekering kan de kracht van een regionaal bestuur vergroten, indien de financiële middelen via haar aan de instellingen ter beschikking komen. De overgang naar het dienstverband biedt de mogelijkheid tot een betere organisatorische en financiële inpassing van de medisch specialist.

Dit hoofdstuk eindigt met het aangeven van de plaats van de resultaten van dit onderzoek in de in Nederland gaande diskussie over regionale financiering.

\subsection{MOGELIJKHEDEN VOOR EEN ONTWIKKELINGSPROCES}

De volgende wijzigingen van het bestaande Nederlandse financieringsstelsel lijken te kunnen leiden tot het vervullen van de voorwaarden genoemd in paragraaf 6.5.

1. Advisering door het regiobestuur op vrijwillige basis

Zolang de provinciebesturen (gewesten, grote gemeenten) wettelijk niet in staat zijn de onder de genoemde voorwaarden vermelde beslissingen te nemen, kunnen ze wel een adviesfunktie op zich nemen. Het provinciebestuur kan aan de nationale instanties adviseren over het aktiviteitenpakket, capaciteit, arbeidsplaatsen, investeringen en jaarbudget van individuele instellingen. Dit advies kan zich met name rich- 
ten op de taakafbakening, het opsporen van doublures en het bereiken van schaalvoordelen. Ten aanzien van de jaarbudgetten geldt dan, dat het regionale bestuur deze alleen beoordeelt op de aanwezigheid van veranderingen, die samenhangen met een funktieuitbreiding of funktieverandering van de instelling. De nationale instanties - Ministeries, COZ, Ziekenfondsraad - blijven de enige, die de begroting van de desbetreffende instelling vaststellen. Naarmate de nationale instanties zich meer baseren op deze regionale adviezen, winnen deze aan bestuurskracht. Op deze wijze zijn op regionaal niveau de benodigde management- en besluitvormingsstrukturen op te bouwen. Een experiment in één provincie, met de vorming van een bureau, dat adviseert en ressorteert onder het provinciaal bestuur, zou een allereerste stap kunnen zijn.

\section{Omzetting van rijksfinanciering in financiering van de lokale overheid}

Thans wordt in Nederland een aantal extramurale instellingen gefinancierd door het rijk. Denkbaar is, dat deze financiering overgenomen wordt door het regionale bestuur. In eerste instantie zal dit kunnen door een vervanging van de rijkssubsidie rechtstreeks aan de instellingen door een rijksbijdrageregeling aan het regiobestuur, dat daarna als enige subsidiënt optreedt. In tweede instantie is te denken aan een vergroting van het eigen belastinggebied van het regionale bestuur ter vervanging van het rijksbijdragestelsel. Een dergelijke ontwikkeling zou de betrokkenheid van de regiobevolking kunnen stimuleren, omdat de lokale democratie wordt gestimuleerd. Verder zou een dergelijke stap de afstemming met de maatschappelijke dienstverlening kunnen stimuleren, aangezien deze ook met rijksbijdrageregelingen wordt geconfronteerd.

\section{De opbouw van een regionaal informatiesysteem}

In Friesland en Zuid-Limburg zijn thans de regionale kosten van de gezondheidszorg berekend. Wil een regio-adviesmodel, zoals in deze studie beschreven, kunnen funktioneren, dan zullen de regionale adviezen moeten steunen op voldoende informatie over de regio als geheel en over de afzonderlijke instellingen. Friese en Zuid-Limburgse experimenten zouden bij de verdere uitbouw van een dergelijk informatiesysteem als uitgangspunt kunnen dienen.

4. Regionaal toewijzen van financiële bouwplafonds voor intramurale instellingen

Op het gebied van advisering over nieuwbouw van intramurale instellingen hebben de provinciale besturen reeds enige jaren ervaring. Deze advisering kan overgaan in besluitvorming, indien per kategorie instelling nationale bouwplafonds worden vastgesteld, die elk op basis van een formule worden toegewezen aan de provincies. Deze formule is dan van dien aard, dat rekening wordt gehouden met het inwonertal en de omvang en bouwkundige toestand van de bestaande capaciteit in de regio. De RAWP-formule voor investeringen kan hierbij als een uitgangspunt dienen voor de ontwikkeling van een Nederlandse formule.

5. Het introduceren van taakstellende begrotingen voor de discontinu, variabele infrastruktuur van de intramurale instellingen

Deze infrastruktuur betreft in ieder geval het aantal arbeidsplaatsen en de aanwezige apparatuur. Indien het $\mathrm{COZ}$ het maximum van deze infrastruktuur vaststelt dat in aanmerking komt voor financiering uit de tarieven, ontstaan er voor de werkeenheid twee veranderingen ten opzichte van de bestaande praktijk. Allereerst is de werkeenheid gegarandeerd van een financiering van deze infrastruktuur. Bij begrotingsonderschrijdingen ten aanzien van de inkomsten mogen tekorten een jaar later worden verrekend. Ten tweede zullen extra-inkomsten van de werkeenheid ten gevolge van extra-aktiviteiten niet voor een uitbreiding van de infrastruktuur boven het toegestane maximum worden aangewend. Op deze wijze kan de bestaande prikkel tot meer produktie worden verminderd. 


\section{Regionalisatie van een aantal COZ-normen}

Indien op regionaal niveau ervaring is opgebouwd met de advisering sub 1., wordt het mogelijk, dat het $\mathrm{COZ}$ een aantal normen niet per instelling in een regio, maar voor een groep gelijksoortige instellingen tezamen haar normen hanteert. Met name de normen van een aantal ondersteunende diensten, zoals administratie, management, opleiding, technische dienst en de huishoudelijke dienst kunnen hiervoor in aanmerking komen. Het regionale bestuur kan deze normen dan eventueel gedifferentieerd aan de werkeenheden doorgeven. Ook kan ze besluiten bepaalde diensten te verzelfstandigen en rechtstreeks te financieren. Hierdoor is het regionale bestuur in staat bepaalde accenten in haar beleid te geven. Voorwaarde hierbij is wel de aanwezigheid van voldoende management op regionaal niveau.

\section{Afschaffing tariefsysteem bij door de AWBZ gefinancierde instellingen}

Indien de kosten van intramurale instellingen taakstellend worden bepaald (zie sub 3.), hebben de te hanteren tarieven alleen een funktie als verdeelsleutel voor de verschillende verzekeringsinstellingen. Indien er slechts sprake is van één verzekeringsinstelling - hetgeen het geval is bij verpleeghuizen en andere uit het AFBZ betaalde vervalt ook deze bestaansgrond van het tarief. Door dit dan af te schaffen kan ervaring worden opgedaan met budgetfinanciering als alternatief voor het tariefstelsel.

8. Instelling van een regeling om budgettair neutrale verschuivingen in het zorgaanbod van een regio over te laten aan het regiobestuur

Indien de begrotingen van de werkeenheden grotendeels taakstellend zijn (zie sub 3.), wordt het mogelijk voor een regiobestuur te adviseren een nieuwe taak te financieren ten koste van een bestaande taak. Indien een regiobestuur dan binnen zo'n meerjarenraming wil schuiven binnen het zorgaanbod, zou dit als standaardregel moeten worden toegestaan (overgelaten) door de nationale. instantie aan het regionale bestuur. Op deze wijze is de verschuiving van intra-naar extramurale en van acute naar chronische zorgverlening te stimuleren. Indien bovendien de erkenningskriteria voor instellingen en chronische zorg wordt geformuleerd in zorgbehoeften van patiënten, wordt het mogelijk nieuwe soorten werkeenheden eventueel ten koste van bestaande werkeenheden te financieren.

9. Het schonen van honoraria van medisch specialisten van bestanddelen, die bestemd zijn voor de infrastruktuur

Deze laatste wordt dan via taakstellende begrotingen van het ziekenhuis gefinancierd. Op deze wijze kan de infrastruktuur van een ziekenhuis als totaal door het regiobestuur worden beoordeeld.

\section{Regionalisatie van het ziekenfondswezen}

Indien de werkgebieden van de ziekenfondsen gaan samenvallen met die van de regiobesturen voor de gezondheidszorg, kan ten eerste hierdoor de opbouw van een informatiesysteem in de regio worden ondersteund. Ten tweede kan de verhouding tussen regiobestuur en ziekenfondsbestuur zich uitkristalliseren. Ten derde zou een aansluiting op de per provincie werkende verzekeringsinstellingen voor ambtenaren in dienst van lokale overheden kunnen plaatsvinden. Bovendien wordt ingehaakt op de neiging van de particuliere verzekeringsinstellingen om meer regionaal te gaan werken (Groot, 50). In Engeland kennen de health area's en health districts treasury departments, waar de eerste verantwoordelijkheid ligt voor het financiële beleid van het regiobestuur. In Zweden worden deze gevormd door de hoofdafdeling financiële zaken van de landsting. In Nederland zou een ziekenfonds met een werkgebied dat samenvalt met dat van het regiobestuur kunnen uitgroeien tot een dergelijk financieel beleidsorgaan, zij het dat het alleen voor de bij haar verzekerden verantwoording kan dragen. 
11. Het brengen van academische ziekenhuizen onder de werking van het Wetsontwerp Voorzieningen Gezondheidszorg

De funkties van een academisch ziekenhuis betreffen de zorgverlening aan patiënten, de opleiding van medische studenten en het medisch-wetenschappelijk onderzoek. Indien haar aktiviteitenpakket ten behoeve van de zorgverlening aan patiënten in de regio wordt beoordeeld door het regiobestuur, is een afstemming mogelijk met die van andere werkeenheden in een regio. Het verruimen van de werking van het Wetsontwerp Voorzieningen Gezondheidszorg is hiervoor een van de middelen, die kunnen leiden tot de vorming van "academische regio's" zoals in Engeland.

\subsection{RESULTATEN VAN HET ONDERZOEK EN DE IN NEDERLAND GAANDE DISCUSSIE OVER REGIONALE FINANCIERING}

In paragraaf 1.1. is aangegeven dat een inleiding van Groot (49) voor de Nederlandse vereniging voor Ziekenhuiseconomen, en een aantal opmerkingen in de Struktuurnota Gezondheidszorg, de discussie stimuleerden over mogelijkheden van regionale financiering en over een vervanging van het vigerende tariefsysteem door een financiering van werkeenheid op basis van ingediende budgetten (Ministerie van $V \& M, 68$ ).

Eind 1978 lijkt de discussie zich toe te spitsen op de volgende onderwerpen:

1. definitorische vraagstukken

2. de afweging van het tariefstelsel tegen budgetfinanciering

3 . de afweging van funktionele tegen regionale financiering

In deze paragraaf wordt getracht eerst per onderwerp de huidige stand van zaken met betrekking tot de gedachtenontwikkeling samen te vatten. Daarna wordt aangegeven waar de bevindingen van dit onderzoek op aansluiten.

\subsubsection{Definitorische vraagstukken}

Sinds de rede van Groot en de opmerkingen in de Struktuurnota Gezondheidszorg is een discussie gaande over de begrippen budgetten en budgettering. Groot (49) stelt dat het begrip budgettering in verschillende betekenissen is te gebruiken. In eerste instantie als "raming van kosten en opbrengsten (. . .), welke raming voor een bepaalde periode wordt opgesteld". Ten tweede is budgettering op te vatten als "een stelsel van financiering van economische eenheden werkend binnen de gezondheidszorg op basis van jaarlijkse kostenbudgetten". Deze laatste vorm noemt hij externe budgettering in tegenstelling tot de eerstgenoemde, waarvoor hij de term interne budgettering reserveert. Bij de externe budgettering onderscheidt hij vaste en variabele budgettering: " $\mathrm{Bij}$ de vaste budgettering krijgt de economische eenheid een vast budget en moet daarmee zien rond te komen. Correctie is eigenlijk alleen mogelijk op basis van loon- en prijsstijgingen, die de economische eenheid immers als exogene faktor heeft te accepteren (...). Bij een variabel budget wordt het budget - naast compensatie voor loon- en prijsstijgingen - ook nog gecompenseerd voor de veranderingen in de volumina". De externe budgettering stelt Groot tegenover het tariefstelsel, "waarbij de economische eenheden hun inkomsten ontvangen op basis van verrichtingen". In latere publicaties, zie hieronder, wordt het begrip budget meer gezien in de zin van intern budget. De Commissie Budgetfinanciering van de Ziekenfondsraad omschrijft de term "budget" als "een gekwantificeerde opstelling, vertaald in geld, van mankracht en materiële middelen, die nodig zijn om zo doelmatig mogelijk de volgens de planning te verrichten aktiviteiten uit te voeren" (Ziekenfondsraad, 113).

Door het Ministerie van V \& M wordt budgettering omschreven als "een instrument 
voor procesbeheersing waarbij de beheersing van de aktiviteiten en de daaraan verbonden kosten voorop staat" (Ministerie van $V \& M, 70$ ). De term budgettering blijft in zowel interne als externe zin van Groot in gebruik (Ziekenfondsraad, 113 en $\mathrm{Na}$ tionale Ziekenhuisraad, 76).

In de loop der jaren komen andere begrippen naar voren met een gelijke strekking als "externe budgettering". Te noemen zijn "budgetsysteem" (COZ-jaarverslag, 1974), "kostenvergoeding in de vorm van periodieke uitkeringen" (Ministerie van V $\& M, 70)$ "inputfinanciering" (Werner, 100) en "budgetfinanciering" (Ziekenfondsraad, 113). In plaats van "tariefstelsel" komen ook de termen "tariefsysteem" (COZ jaarverslag 1974) en "outputfinanciering" (Werner, 100) naar voren. Het COZ stelt het tariefstelsel gelijk aan een stelsel met variabele budgettering ( $\mathrm{COZ}$ jaarverslag 1974).

In deze studie wordt de term budget(tering) gebruikt in de zin van die van het Ministerie van $V \& M(70)$. Deze term is synoniem aan begroting (begroten). Het beschikbaar stellen van financiële middelen op basis van ingediende budgetten wordt in deze studie "budgetfinanciering" of "financiering op basis van budgetten" genoemd. De keuze is gebaseerd op het feit, dat in het Engels de termen "budget", "budgetary" en "budgetting" gereserveerd zijn voor "het beheersingsaspekt". De Engelse begrippen voor budgetfinanciering zijn funding en resource allocation en voor tariefsysteem fee-for-service-system. In deze studie komt financiering voor op basis van geobjectiveerde kriteria, zoals bevolkingsomvang, mortaliteit (RAWP-formule in Engeland), aantal bedden (RHB-formule in Engeland) prijsindices (London Weighing factor in de RAWP-formule). Voor deze vorm van financiering, niet op basis van verrichtingen of ingediende budgetten maar op basis van de waarde van een aantal indices, is de term indexfinanciering bruikbaar.

\subsubsection{Tariefstelsel en budgetfinanciering}

In de discussie over het tariefstelsel en de budgetfinanciering speelt de vraag of het laatste mogelijk is, indien de aktiviteitenomvang niet te budgetteren is. Gesteld wordt dat dit laatste in Nederland thans het geval is, aangezien de arts zelf zijn aktiviteitenomvang bepaalt. De Tarievencommissie van de Nationale Ziekenhuisraad stelt dat "zolang een allesomvattende planning van de gezondheidszorg aktiviteiten - als systeem - onvoldoende scherp is uitgewerkt, dient de externe budgettering te worden afgewezen en biedt het stelsel van tariefzetting op basis van richtlijnen voor de bevordering van de doelmatigheid van het handelen duidelijk meer mogelijkheden" (76). Voor het $\mathrm{COZ}$ is niet de keuze tussen de twee financieringsstelsels interessant, maar de normering van de aktiviteiten. "Kostenbeheersing is binnen alle systemen eerst dan mogelijk, indien in de exploitatiebegroting een normering van de omvang van de dienstverlening is begrepen. In die situatie kan er uit administratieve en controle-overwegingen een voorkeur bestaan voor een budgetsysteem. Onzes inziens moet niet de vraag beantwoord worden, of een tarievensysteem of een budgetsysteem moet worden gehanteerd, maar of een exploitatiebegroting een taakstellend karakter dient te dragen" ( $C O Z$-jaarverslag 1974).

De Jong, voorzitter tarievencommissie van de NZR, stelt:

"Het lijkt onmogelijk aan te geven, hoe een externe budgettering - als bestaand middel - de beheersing van aktiviteiten kan afdwingen. Eerst zal moeten worden vastgesteld, welke goederen, in welke hoeveelheden, in welke perioden moeten worden geproduceerd" $(60)$.

Aan het einde van deze studie is erop te wijzen, dat budgetfinanciering van ziekenhuizen in Engeland en Zweden bestaat, zonder dat aan de aktiviteitenomvang plafonds worden gesteld. In Zweden heeft dit stelsel zelfs bestaan, terwijl de artsen po- 
liklinisch per verrichting werden gehonoreerd. Deze aanwezigheid is reeds voldoende bewijs, dat het kan bestaan. Hoe dit mogelijk is, staat vermeld in paragraaf 6.5.1.

\subsubsection{Funktionele en regionale financiering}

De discussie over funktionele versus regionale financiering speelt zich af aan de hand van twee tegenover elkaar staande modellen. Het ene is ontwikkeld in een discussienota van de Ziekenfondsraad (113). Het andere is uitgebracht in een rapport van de werkgroep Regionale Financiering van de Centrale Raad voor de Volksgezondheid (33).

In het model van de Ziekenfondsraad wordt gepleit voor budgetfinanciering van de werkeenheden. De financiële middelen waarover een werkeenheid kan beschikken, worden vastgesteld door een Raad voor de Gezondheidszorg, die hierbij wordt ondersteund door per soort werkeenheid in te stellen commissies. In te stellen regionale raden mogen deze Raad voor Gezondheidszorg adviseren en zorgdragen voor de financieel-technische afrekening met de werkeenheid. Op deze wijze wordt in dit model het accent gelegd op een centrale financiering per soort werkeenheid (funktionele financiering) (zie ook Brouwer, 15). De werkgroep regionale financiering van de Centrale Raad voor de Volksgezondheid pleit voor een budgetfinanciering van regio's. Ze onderscheidt hierbij twee geldstromen. De eerste - en verreweg de grootste - is bestemd voor de financiering van een basispakket gezondheidszorgvoorzieningen. De aard, de omvang en de kwaliteit hiervan wordt bepaald door centrale, politieke besluitvorming. De tweede geldstroom is ter vrije besteding boven en naast het basispakket.

De Ziekenfondsraad komt tot het model in haar discussienota vanuit de mening, dat het aanbod van zorg en de groei ervan sterk wordt beinvloed door de opleiding van werkers en door investeringen in de gezondheidszorg. De samenhang lijkt gemakkelijker funktioneel en primair centraal te beheersen dan vanuit de regio's. De werkgroep brengt haar model om een dam op te werpen tegen te vergaand centraal overheidsingrijpen ( $C R V, 33$, p. 10).

De in deze studie geformuleerde voorwaarden van het financieringsstelsel lijken aan te sluiten bij het model van de Ziekenfondsraad. Wel zijn er duidelijk accentverschillen. Hier wordt gepleit voor beoordeling van funktie- en aktiviteitenpakketten van werkeenheden door het provinciaal bestuur. Er wordt een link gelegd met de operationele en strategische plannen. De Ziekenfondsraad lijkt meer "type werkeenheden" dan funkties te onderscheiden. Verder lijkt zij aan regionale verzekeringsinstellingen, aan "ziekenfondsen-nieuwe stijl" de beoordeling van de instellingsbegroting te willen overlaten. Een overeenkomst van beide modellen is, dat de begroting van de instelling wel op nationaal niveau wordt vastgesteld.

Het model van de werkgroep van de Centrale Raad voor de Volksgezondheid is in deze studie niet uitgewerkt omdat aan de betekenis van twee geldstromen voor een regionale prioriteitstelling wordt getwijfeld. Ten eerste biedt de eerste geldstroom al mogelijkheden tot regionale prioriteitenstelling, indien nationale instanties vooral ten aanzien van regio's als geheel besluiten nemen. De tweede geldstroom is dan niet nodig "als dan tegen te vergaand centraal overheidsingrijpen". Ten tweede wordt het zeer moeilijk de beide geldstromen uit elkaar te houden. Vaak zal het eigen beleid van een regio bestaan uit het leggen van accenten binnen het basispakket, bijvoorbeeld door het toestaan van een iets hogere personeelsbezetting in een ziekenhuis dan volgens de landelijke normen mogelijk is. Ten derde zal de tweede geldstroom zeer gering zijn ten opzichte van de eerste, waaruit die zorg moet worden gefinancierd, die nu in het ziekenfonds- en AWBZ-pakket is opgenomen. Dit pakket is echter al zeer uitgebreid. Al met al lijkt een tweede geldstroom overbodig. 




\section{SAMENVATTING}

Dit onderzoek is gericht op de financieringsaspekten van de regionalisatie van de Nederlandse gezondheidszorg. Getracht wordt in deze studie een antwoord te geven op de volgende vraagstelling:

"Aan welke voorwaarden moet een financieringsstelsel van de Nederlandse gezondheidszorg voldoen, dat gebaseerd is op de volgende uitgangspunten:

- een regionalisatie van de formele organisatiestruktuur van de gezondheidszorg,

- het leveren van positieve bijdragen aan het bereiken van thans geldende doelstellingen van het nationale beleid ten aanzien van de gezondheidszorg,

- de mogelijkheid op middellange termijn te worden verwezenlijkt vanuit het thans bestaande financieringsstelsel".

Gekozen is voor een inductieve onderzoeksmethode, waarbij na een inventarisatie de Nederlandse gezondheidszorg vergeleken wordt met die van Engeland en Zweden, twee landen met tegenwoordig regionale strukturen voor de gezondheidszorg. $V$ an de drie landen worden achtereenvolgens geïnentariseerd en vergeleken de omgeving, de organisatiestruktuur, de formele besluitvormingsstruktuur en de doelstellingen. Het financieringsstelsel komt aan de orde als onderdeel van de formele besluitvormingsstruktuur. De beschrijving van de doelstellingen richt zich op thans in Nederland geldende doelstellingen van het nationale gezondheidszorgbeleid.

Onderscheiden worden vijf doelstellingen te weten:

1. het handhaven van het niveau en de kwaliteit

2 . het afremmen van de groei van de totale kosten

3. het bereiken van een evenwichtige geografische spreiding

4. het verbeteren van de integratie

5 . het vergroten van de betrokkenheid van patiënten en zorgverleners

Op basis van het vergelijken van de drie landen worden de uitgangspunten geformuleerd in de probleemstelling uitgewerkt en de voorwaarden van het financieringsstelsel geformuleerd.

Gegevens over de drie landen werden verkregen door de raadpleging van literaturur, statistieken en andere schriftelijke stukken, door het houden van interviews met betrokkenen bij de besluitvorming, alsmede door observatie van de besluitvorming in de verschillende landen. Getracht is ervaringen van verschillende regio's in Engeland en $\mathrm{Zweden}$ in het onderzoek te betrekken (zie grafieken 1.3.2.1. en 1.3.2.2.). Een concept van het zesde hoofdstuk werd voorgelegd aan achttien bij het onderwerp betrokken personen in Nederland.

Op basis van het vergelijken van de verkregen gegevens over de drie landen en op basis van de uitgangspunten in de probleemstelling worden de volgende voorwaarden voor een financieringsstelsel van een geregionaliseerde Nederlandse gezondheidszorg genoemd (par. 6.5.).

a. Het aangeven van het maximum van de kosten van de infrastruktuur van een vrije beroepsbeoefenaar in de extramurale gezondheidszorg, dat in de tarieven mag worden doorberekend.

b. Het vervangen van vergoedingen uit het specialistenhonorarium voor de kosten van de infrastruktuur van een medisch specialist in een instelling door een financiering uit de inkomsten van de instelling.

c. Het hanteren van een taakstellend of gesloten budget voor de infrastruktuur van een instelling en een open budget voor de middelen. 
d. Het koppelen van de jaarlijkse begroting van instellingen aan regionale operationele en strategische plannen.

e. Het invoeren van een stelsel van gedifferentieerd begroten door de instelling, waarbij de kosten van wijzigingen in aktiviteitenpakket, personeelsbezetting, apparatuur en huisvesting duidelijk naar voren komen.

f. Het opstellen van regionale adviezen over de wijzigingen sub e. aan de nationale instantie, die de tarieven van instellingen vaststelt.

g. Het vervangen van de subsidies van het rijk aan instellingen door rijksbijdragen aan regionale besturen en regionale subsidies aan deze instellingen.

$h$. Het hanteren van een financieel bouwplafond voor investeringen per regio en per kategorie instelling.

i. Het aangeven door het rijk van de gewenste financiële groei van de infrastruktuur per regio en per zorgsoort.

Een financieringsstelsel gebaseerd op deze voorwaarden zal op grond van de bevindingen in Engeland en $Z$ weden naar verwachting bijdragen kunnen leveren aan de verschillende hierboven genoemde doelstellingen (par. 6.6.).

In een nabeschouwing (hoofdstuk 7) wordt ingegaan op een aantal mogelijkheden om een dergelijk financieringsstelsel te ontwikkelen. Ook wordt dan ingehaakt op lopende discussies over het financieringsstelsel van de Nederlandse gezondheidszorg. 


\section{SUMMARY}

This study examines the economic/financial aspects and the regional organisation of the Dutch health care system in an attempt to answer the following question:

"What conditions must be fulfilled if the financing system of Dutch health care is to make a positive contribution to the attainment of the current objectives of national policy on health care, given that the formal organisational structure is regionally based and that any proposals made are feasible in the medium term?"

Having decided on an inductive method of research, the Dutch health care system is described in detail and compared with those of England and Sweden both of which have regionally based health care structures. For the three countries comparisons were made of first, the social-political environments; secondly, the organisational structures; thirdly, the formal decision-making structures; and finally, the objectives of the different health care systems. The financing arrangements are discussed as part of the formal decision-making structures.

In the discussion of objectives, those objectives currently obtaining in the national policy on health care in the Netherlands are considered.

Five of these have been identified, viz.

1. maintaining the standards and quality of health care;

2. reducing the rate of growth of total expenditure;

3. achieving an equitable distribution of resources geographically;

4. improving the integration of services; and

5 . increasing the involvement of patients and staff.

From a comparison of the three countries the issues raised by the basic questions posed above are elaborated and the conditions of the financing system formulated.

Data for the three countries were obtained through recourse to the relevant literature and to various official/published statistics; by conducting interviews with various people actually involved in health care decision-making; and through observation of the decision-making processes in the three countries. The experiences of decisionmaking in various regions studied in England and Sweden were incorporated in the study (see graphs 1.3.2.1. and 1.3.2.2.). A draft of the six th chapter was submitted for comment to eighteen individuals involved in decision-making in health care in the Netherlands.

On the basis of a comparison of the data obtained for the three countries and of the issues under investigation, the following conditions for a financing system for a regionally sub-divided health care service in the Netherlands were determined (section 6.5.):

a. in the scale of professional fees in the community/primary care services, the specification of a maximum additional amount to cover overheads such as the cost of ancillary staff;

b. within hospitals that part of the fee to cover a medical specialist's overheads should be obtained from the revenues of the hospital;

c. institutes should operate with a fixed budget for administrative and other overheads but an open-ended budget for expenditure on actual services;

$d$. the budget of individual institutes should be linked with operational and strategic plans at the regional level;

e. institutes should introduce a system of budgeting which clearly demonstrates the 
costs of new activities in terms of different sets of activities, staffing, equipment and accommodation;

f. the presentation of regional reports on the new activities under e. to the national authority who is then responsible for fixing the scale of charges for the institutes;

g. replacing government grants direct to institutes by a system whereby the government contributes to regional authorities who in tum make grants to the institutes in their region;

$h$. fixing upper limits to investment in buildings both regionally and by category of institutes; and

i. the specification by the government of the desirable growth in expenditure for each region and for different services.

In the light of the experiences in health care in England and Sweden, a financing system based on these conditions could be expected to contribute to the objectives of the Dutch health care system listed above (section 6.6.).

In an epilogue (Chapter 7), against the background of a number of issues regarding the current financing system of Dutch health care, a number of possible ways of developing alternative financing systems are discussed. 


\section{SAMMANFATTNING}

Den här undersökningen behandlar den nederländska hälso- och sjukvårdens indelning i regioner ur finansieringssynpunkt. Studien söker ge svar på följande frågeställning:

"Vilka villkor måste den nederländska hälso- och sjukvårdens finansieringsstruktur uppfylla förutsatt att den grundar sig på följande utgångspunkter:

- en indelning i regioner av hälso- och sjukvårdens formella organisationsstruktur

- att positivt bidraga till att de målsättningar för hälso- och sjukvården som i dag gäller inom hälso-och sjukvårdspolitiken kan förverkligas

- möjligheten att utifrån den nuvarande finansieringsstrukturen kunna uppfylla dessa villkor inom en inte alltför lång tidsperiod."

Valet föll på en induktiv undersökningsmetod, sålunda jämföres efter en inventering den nederländska hälso- och sjukvården med hälso- och sjukvården i England och Sverige, två länder där hälso-och sjukvården för närvarande är regionalt strukturerad. I dessa tre länder görs en inventering samt en jämförelse av i nämnd ordning: omgivningen, organisationsstrukturen, den formella strukturen för beslutsförfarande och målsättningarna. Finansieringsstrukturen behandlas som en del av den formella strukturen för beslutsförfarande. I beskrivningen av målsättningarna ligger tonvikten på de målsättningar för hälso- och sjukvårdspolitiken som gäller i Nederländerna i dag.

Härvid urskiljes fem målsättningar nämligen:

1. att nivån och kvaliteten bibehålles

2. att de totala kostnadernas tillväxt hämmas

3. att en jämn geografisk fördelning uppnås

4. att integrationen förbättras

5. ett ökat engagemang hos patienter och personer verksamma inom hälso- och sjukvården.

Med jämförelsen mellan de tre länderna som grund utarbetas problemställningens utgångspunkter och formuleras villkoren för finansieringsstrukturen.

Uppgifter om de tre länderna erhölls genom att konsultera litteratur, statistik och andra publikationer, genom intervjuer med personer som deltagit $i$ beslutsförfarandet samt medelst observation av beslutsförfarandet $i$ de olika länderna. En strävan har varit att lăta erfarenheter från olika regioner i England och Sverige ingå i undersökningen (se digram 1.3.2.1. och 1.3.2.2.). Första utkastet till sjätte kapitlet förelades aderton personer i Nederländerna vilka är insatta $i$ ämnet.

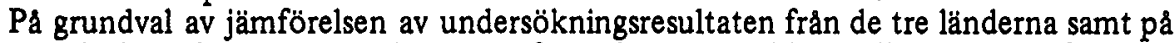
grundval av de utgångspunkter som formulerats i problemställningen kan följande villkor för finansieringsstrukturen i en i regioner indelad nederländsk hälso- och sjukvård nämnas (avsnitt 6.5.).

a. Fastställande av en maximigräns för de kostnader för utrustning som en fri yrkesutövare inom den öppna vården tillåts inberäkna $i$ honoraret.

b. De omkostnader för utrustning som en specialist, verksam vid en institution, har fár ej inberäknas $i$ honoraret utan skall finansieras med medel från institutionens inkomster.

c. Tillämpning av en "stängd" budget för institutionens utrustning och en "öppen" budget för medlen. 
d. Institutionernas årsbudget måste passa inom de regionala, operationella och strategiska planerna.

e. Införandet av en differentierad budgetering vid institutionema varvid kostnaderna för ändringar vad beträffar verksamhetskategorier, personalstyrka, utrustning och byggnader skulle bli lättare urskiljbara.

f. Utarbetande på regional nivå av förslag rörande ändringarna (se 3) till den statliga myndigheten vilken fastställer institutionernas taxor.

g. Utbetalning av statsbidrag till regionala myndigheter och regionala bidrag till institutionerna skall ersätta det nuvarande systemet som innebär att statsbidragen utbetalas direkt till institu tionerna.

$h$. Tillämpning av en maximigräns för investeringar $i$ byggnader per region och per institutionskategori.

i. Riktlinjer uppställda av staten beträffande hur mycket kostnaderna för utrustning får stiga per region och per vårdkategori.

En finansieringsstruktur vilken uppfyller dessa villkor skall enligt vad undersökningsresultaten i England och Sverige utvisar kunna bidraga till förverkligandet av ovan nämnda målsättningar (avsnitt 6.6).

I en efterskrift (kapitel 7) diskuteras olika sätt för utvecklandet av en dylik finansieringsstruktur. Härvid anknytes till diskussioner som för närvarande förs om den nederländska hälso- och sjukvårdens finansieringsstruktur. 


\section{LIJST VAN GECITEERDE LITERATUUR}

Tijdens het onderzoek is in het Instituut voor Ziekenhuiswetenschappen een archief samengesteld over de regionalisatie en financiering van de gezondheidszorg in Engeland, Zweden en Nederland.

Alleen de stukken hieruit, die zijn geciteerd in dit boek, worden hieronder vermeld. Voor de gebruikte afkortingen zij verwezen naar de desbetreffende lijst op pagina VIII van dit boek. De cijfercode aan het eind van een literatuuropgave verwijst naar de desbetreffende paragra(a)f(en) van dit boek.

\section{NEDERLAND}

1. Advies van de Commissie ad hoc inzake de mogelijkheid tot verbetering van de organisatie van de gezondheidszorg en het funktioneren daarvan, rapport commissie-Festen, Leidschendam, z. uitg., 1973. (1.1.)

2. Aert, J.H. van, Ziekenhuiskosten in economisch perspectief, Utrecht, NZI, 1977. (5.4.2.)

3. Aert, J.H. van, \& A.P.W.P. van Montfort, Econometrische analyse in het kader van het basisonderzoek kostenstruktuur ziekenhuizen, Utrecht, NZI, 1977, vijf delen. (5.2./6.5.1.)

4. Anbeek, H.J., Effektiviteit van organisatie en financieringsstruktuur van de gezondheidszorg, in: Nieuwe strukturen van de gezondheidszorg, Lochem, De Tijdstroom, 1974. (5.2.)

5. Andriessen, L.B.J.J., Toekomstige Struktuur gezondheidszorg in Nederland (11), Medisch Contact, 1971, p. 69-73. (1.1.)

6. Beleidsvoornemens betreffende de kostenbeheersing in de Gezondheidszorg, Tweede Kamerstukken zitting 1975-1976, stuk nr. 1, Den Haag, Staatsuitgeverij, 1975. (5.4.2.)

7. Belleman, S.J.M., Ontwikkelingen in de vraag naar specialistische hulp, 1977, Nationaal Ziekenhuis Instituut, Utrecht. (5.4.1.)

8. Berenschot, GITP en Bosboom Hegener, Onderzoek Beheersbaarheid Gezondheidszorg, Utrecht, Nijmegen en Amsterdam, z. uitg., 1973. (1.1.)

9. Bergsma, J., Hoe was het in het ziekenhuis. Een landelijk onderzoek naar ziekenhuiservaringen, z. uitg., vakgroep klinische psychologie en psychotherapie van de K.H. Tilburg, Tilburg, 1977. (5.4.5.1.)

10. Bestek 81 , Hoofdlijnen van het financiële en sociaal-economische beleid voor de middellange termijn, Tweede Kamer, zitting 1977-1978, stuk 1501. (5.1.1.)

11. Blankenstijn, $C$, e.a., Handleiding Financiering Welzijnsvoorzieningen, Alphen aan den Rijn, Samsom, 1977. (5.3.1.)

12. Blox, J.T. \& J.A.M. Theeuwes, Kostenberekening in Ziekenhuizen, Acta Hospitalia, 1975, nr. 1, p. 128-145. (5.4.2.)

13. Boot, J.M.D. \& J.L.M. Zuidberg, De sluiting van een zeer klein ziekenhuis als een proces van competitieve uitsluiting, Acta Hospitalia (18), 1978, nr. 3, p. 285-304. (5.4.4.)

14. Boot, J.M.D. \& J.L.M. Zuidberg, De adviespraktijk van het College Ziekenhuis voorzieningen en de ontwikkeling van de ziekenhuizen, Het Ziekenhuis, 1977, (7), nr. 7, p. 188-193 en nr. 8, bijvoegsel. (5.4.2.1.)

15. Brouwer, $E$., Budgettering, funktioneel, Samenvatting inleiding studiedag NZR over budgettering, Utrecht, z. uitg., 1978. (7.2.3.) 
16. $C B S$, De leefsituatie van de Nederlandse bevolking 1974 , Den Haag, Staatsuitgeverij, 1975. (2.1.1.)

17. $C B S$, De toekomstige demografische ontwikkeling in Nederland na 1975, Den Haag, Staatsuitgeverij, 1976. (5.1.1.)

18. $C B S$, Kosten en financiering van de Gezondheidszorg in Nederland 1974, Den Haag, Staatsuitgeverij, 1977. (5.3.2.)

19. $C B S$, Maandstatistiek van de bevolking en de volksgezondheid 1976, Den Haag. (5.1.2.)

20. $C B S$ Ministerie van $V \& M$, Compendium Gezondheidsstatistiek Nederland 1974, Den Haag, Staatsuitgeverij, 1974. (5.4.1.)

21. $C B S$, Nationale rekeningen 1960 en 1977 , Zeist, De Haan, 1961 en Den Haag, Staatsuitgeverij, 1978. (5.1.1.)

22. $C B S$, Statistisch zakboek $1971 \mathrm{t} / \mathrm{m}$ 1978, Den Haag, Staatsuitgeverij, 19711978. (4.1.1.)

23. $C B S$, Sterftetafels voor Nederland, afgeleid uit waarnemingen 1950-1952, Den Haag, Staatsuitgeverij, 1953. (5.1.2.)

24. Collectieve Voorzieningen en de Werkgelegenheid, Tweede Kamerstukken 1975-1978. (5.1.1.)

25. Commissie Van der Burg, Diskussienota (1975) en rapport inzake het democratisch en doelmatig funktioneren van gesubsidieerde instellingen, Rijswijk, Ministerie van CRM, 1975-1977. (5.4.5.2.)

26. COZ, COZ-Vademecum, Alphen aan den Rijn, Samsom, 1978. (5.3.2.)

27. COZ, Jaarverslagen 1971-1977, Utrecht, z. uitg., 1975. (1.2.)

28. Chardon, A.J., Eisen vanuit de klinische gezondheidszorg te stellen aan de financieringsstrukturen, in: Nieuwe Strukturen van de Gezondheidszorg, verslagen najaarsstudiedagen 1973 van de Stichting Studiecentrum Ziekenhuiswetenschappen, Lochem, De Tijdstroom, 1974. (1.1.)

29. $C R V$, Advies inzake het wetsontwerp Voorzieningen Gezondheidszorg, Den Haag, Staatsuitgeverij, 1977. (6.4.3.)

30. $C R V$, Benadering van de ontwikkeling van de kosten van de Nederlandse Gezondheidszorg, derde rapport, Den Haag, z. uitg., 1976. (5.4.2.3.)

31. $C R V$, Eerste advies inzake regionalisatie in de gezondheidszorg, Den Haag, Staatsuitgeverij, 1973. (1.1.)

32. $C R V$, Kommentaar op Struktuurnota Gezondheidszorg, Den Haag, Staatsuitgeverij, 1975. (1.2./5.4.4.)

33. $C R V$, Nota inzake gedecentraliseerd financieel beleid, Den Haag, Staatsuitgeverij, 1977. (1.1./7.2.3.)

34. $C V Z$, Huishoudelijk reglement, 1977, z. uitg., Utrecht. (5.3.1.)

35. CVZ, Rapport "Korte Termijn", Utrecht, z. uitg., 1973. (1.2.)

36. CVZ, ziekenhuiscommissie, Jaarverslagen 1974-1977, Utrecht, z. uitg., 19751978. (1.2./5.3.1.)

37. Damen, P.C. \& W.J.F.I. Nuijens, De struktuur van de Nederlandse gezondheidszorg, Lochem, De Tijdstroom, 1976. (5.2.)

38. Domela Nieuwenhuis, $V$., Kommentaar van de FNV op het Wetsontwerp voorzieningen gezondheidszorg alsmede op het Wetsontwerp tarieven gezondheidszorg, Amsterdam, 2. uitg., 1977. (1.1.)

39. Van Doorn-de Leeuw, M., Wie gaat de gezondheidszorg beheersen?, Beleid en Maatschappif, (IV), 1977, nr. 5, p. 141-147.(1.1.)

40. Dussen, J.W. van der, Rijksbijdragen van CRM, Openbare Uitgaven, 1977, $\mathrm{nr}$. 4, 144-151. (6.5.2.)

41. Dijkstra, H.J., Management en budgettering, Het Ziekenhuis, 1975, p. $592-$ 595.(1.1.)

42. Eupen, J. van, De concept-rijksbijdrageregeling sociaal-cultureel werk: een riskante onderneming. Tijdschrift voor Maatschappij vraagstukken en Welzijnswerk (I), 1977, p. 111-119. (6.5.2.) 
43. Festen, H., De toekomstige struktuur van de gezondheidszorg, Medisch Contact, 1971, p. 606-607. (5.4.1.)

44. Gezondheidswet 1956, Staatsblad 1956, no. 51. (5.3.1.)

45. Gezondheidszorg en democratisering, een publikatie van het Nederlands Gesprekscentrum, Bosch en Keuning NV, Baarn, 1979. (5.4.5.2.)

46. GHI, Jaarverslagen 1958 en 1976, Den Haag, Staatsuitgeverij, 1959 en 1977. (5.4.3.)

47. GHI, per 1-1-1979 ingevolge de AWBZ erkende psychiatrische ziekenhuizen, erkende verpleeghuizen en afdelingen van gekombineerde verpleeghuizen voor psychische gestoorde(n) (bejaarden) en erkende zwakzinnigen inrichtingen, Leidschendam, z. uitg., 1979. (5.2.)

48. Grinten, T. van der, Financiering van samenwerking in de eerste lijn, Medisch Contact, 32, 1977, p. 1032-1037. (5.3.2.)

49. Groot, L.M.J., Budgettering en beheersbaarheid, inleiding voor de voorjaarsledenvergadering van de NVZE op 22 april 1975. Het Ziekenhuis, 1975, nr. 12, bijvoegsel, p. 3-15, 1975. (1.1./7.2.)

50. Groot, L.M.J., Feestrede bij gelegenheid van het vijftig jarig bestaan van het ziekenfonds ZNL te Venlo, Venlo, z. uitg., 1979. (7.1.)

51. Groot, L.M.J., Gezondheidszorg en Bestek 81, Economisch-Statistische Berichten, 1979, p. 572. (5.3.1.)

52. Groot, L.M.J., Kostenontwikkeling in de gezondheidszorg. Maatschappij Belangen, nr. 10,1976, p. 753-771. (5.4.1.)

53. Groot, L.M.J., Bedrijfseconomie in het Ziekenhuis en het COZ. Maandblad voor Accountancy en Bedriffsadministratie, 1977, p. 298-310. (5.3.2.)

54. Hattinga Verschure, J.C.M., Samenwerking van Ziekenhuizen in een verzorggingsgebied in: Het ziekenhuis in de regio, verslagen studiedagen 1965-1966 van de stichting Samenwerking Amsterdamse Ziekenhuis Amsterdam, Cloeck en Moedigh NV, 1966. (1.1.)

55. Heide, H. ter \& Kalff, D.J.A., De macro-organisatiestruktuur als hulpmiddel bij de beheersbaarheid van de kwaliteit in de gezondheidszorg, in: Beheersbaarheid van kwaliteit, kwantiteit en kosten, Lochem, De Tijdstroom, 1976, p. 66-86. (1.1.16.2.3.)

56. Het beleid ter zake van de gezondheidszorg met het oog op de kostenontwikkeling, Tweede Kamerstuk, zitting 1978-1979, 15, 540, nrs. 1 en 2. (5.3.2.)

57. Idenburg, Ph.A., Regionalisatie in de gezondheidszorg, Tijdschrift voor Sociale Geneeskunde, (54), 1976, p. 451-461. (1.1.)

58. Idenburg, Ph.A., Vragen en kanttekeningen bij een voortgaande discussie, in: Overheid en particulier initiatief, Den Haag, Nationale Raad voor Maatschappij Welzijn, 1977, publicatie nr. 47. (6.2.3.)

59. In 't Veld, J., Analyse van organisatieproblemen, Amsterdam/Brussel, Elsevier, 1978. (1.2.)

60. Jong, L.P. de, Budgettering, wat kan ik er mee, wat doe ik er mee, samenvatting inleiding studiedag NZR over budgettering; Utrecht, z. uitg., 1978. (7.2.2.)

61. Knelpuntennota, knelpunten harmonisatie welzijnsbeleid en welzijnswetgeving, Rapport van de beraadsgroep, stukken Tweede Kamer, zitting 1973-1974, nr. 12.968 nr. 2, Den Haag, Staatsuitgeverij, 1974. (6.5.2.)

62. $K N M G, L H V, L S V \& L A D$, Gezamenlijk Memorandum van de KNMG, LHV, LSV en LAD naar aanleiding van het Wetsontwerp Tarieven Gezondheidszorg, Utrecht, z. uitg., 1977. (1.1./6.4.3.)

63. Leeuwen, P.J. van, Het College voor Ziekenhuisvoorzieningen. Tijdschrift voor Sociale Geneeskunde, (53), 1975, p. 774-779. (5.2.1.)

64. LISZ-jaarboek, Landelijk Informatie Systeem Ziekenfondsen, 1978, Zeist, z. uitg., (5.4.3.)

65. $L S V-N Z R$, sectie ziekenhuizen, Model van een overeenkomst ziekenhuis medisch specialist arts-out contract, Model van een reglement voor de medische staf, Utrecht, z. uitg., 1977. (5.2.) 
66. Miljoenennota 1979, Tweede Kamerstukken, zitting, 1978-1979, 15.300. (5.1.1.)

67. Ministerie van $C R M$, Financieringsalternatieven bejaardenoorden. (6.5.2.)

68. Ministerie van $V \& M$, Struktuurnota Gezondheidszorg, Den Haag, Staatsuitgeverij, 1974. (1.1./4.2./5.2.2./5.4.3./7.2.)

69. Ministerie van $V \& M$, Financieel overzicht van de Gezondheidszorg, waarin opgenomen een raming van de kosten tot 1982 resp. 1983 Den Haag, Staatsuitgeverij, 1977 resp. 1978. (5.4.1.)

70. Ministerie van $V \& M$, Uitgangspunten voor experimenten betreffende budgettering van Ziekenhuizen, 7e concept, Den Haag, z. uitg., 1978. (1.1./7.2.1.)

71. Muntendam, $P$., Ontwikkelingstendenzen in de maatschappelijke gezondheidszorg en hun gevolgen voor het ziekenhuiswezen, in: Het Ziekenhuis in de regio, verslagen van de studiedagen 1965-1966, van de Stichting Samenwerking Amsterdamse Ziekenhuizen, Amsterdam Cloeck en Moedigh, 1966. (1.1.)

72. Nationaal Centrum voor Kruiswerk, Commentaar op de Struktuurnota Gezondheidszorg, d.d. 11 november 1974, Utrecht, 1974, z. uitg. (1.2.)

73. Nationale Ziekenhuisraad, Commentaar op de struktuurnota Gezondheidszorg van augustus 1974, Utrecht, z. uitg., 1974. (1.2.)

74. Nederlandse Vereniging Ambulante Geestelijke Gezondheidszorg, Vijf jaar bouwen aan AGGZ. Utrecht, z. uitg., 1978. (1.2.)

75. NZI, Statistiek personeelssterkte in de instellingen van intramurale gezondheidszorg; 1973 (1974)-1977 (1978), Utrecht, Nationaal Ziekenhuis Instituut. (5.4.1.)

76. $N Z R$, Interimrapport I en II tarievencommissie ziekenhuizen aan het Bestuur van de Sectie Algemene Ziekenhuizen van de Nationale Ziekenhuisraad, Utrecht, z. uitg., 1978. (1.2.)

77. $O E C D$, Public expenditure on health. Paris, z. uitg., 1977. (1.3.1.)

78. Petersen, W.G. \& A.E. Akkerman, Kosten en budgettering van de gezondheidszorg, een oriënterend onderzoek in de provincie Friesland onder leiding van J.J. Witte, Leiden, NIPG/TNO, z. uitg. (5.4.3.)

79. Poels, A.T.J., Budgettering in de intramurale Gezondheidszorg, Het Ziekenhuis (VI), 1976, p. 502-508. (1.1.)

80. Postma, T.J.S., Samenstelling, taak en bevoegdheden van de Ziekenfondsraad, Tijdschrift voor Sociale Geneeskunde, (53), 1975, p. 763-767. (5.2.1.)

81. Pous, J. de, Rede opening Overvecht Ziekenhuis, 1961. (5.4.2.)

82. Provinciale Raad voor de Volksgezondheid Utrecht, Gids gezondheidszorg voor de provincie Utrecht, 1978 , z. uitg., Utrecht. (5.2.)

83. Roy van Zuijdewijn, H.J. de, Het werk van de Gezondheidsraad, Tijdschrift voor Sociale Geneeskunde, (53), 1975, p. 752-756. (5.2.1.)

84. Rutten, F.F.H., The use health care facilities in the Netherlands, and econometric analysis. Leiden, z. uitg., 1978. (1.3.1.)

85. Rutten, F.F.H., J.J. van der Gaag \& B.M.S. van Praag, Het Ziekenhuis en de gezondheidszorg, een economische analyse van het gebruik van ziekenhuisbedden, Leiden, Stenfert Kroese, 1975. (5.4.2.)

86. Rijksuniversiteit Limburg, Voortgangsrapport II Regionaal Kostenmodel verslag van de projektgroep regionaal kostenmodel, Maastricht, z. uitg., 1978. (5.4.3.)

87. Santema, S., Georganiseerde maatschappelijke gezondheidszorg, strukturen, werkzaamheden en raakvlakken, 4e druk, Assen, Van Gorcum, 1976. (5.2.)

88. Schrijver, A., Inventarisatie en bibliografie Struktuumota Gezondheidszorg, Maandblad Geestelijke Volksgezondheid, (30), 1975, nr. 9, bijlage. (1.1.)

89. Siderius, $P$., Toekomstige struktuur gezondheidszorg in Nederland (XI), $M e$ disch Contact, 1971, p. 327-331. (1.1.)

90. Sociaal Economische Raad, "Advies inzake de struktuur van de verzekeringen tegen kosten van geneeskundige verzorging", "Uitgave van de Sociaal-Economische Raad", 1973, nr. 19. (1.1.) 
91. Stolte, J.B., Regionalisatie in de gezondheidszorg. Mogelijkheden en moeilijkheden, Amsterdam, Cloeck en Moedigh, 1968. (1.1.)

92. Tweede Kamer, zitting 1975-1976, stuk nr. 13.600, hoofdstuk 17, nr. 32 en zitting 1977-1978, stuk nr. 14.800, hoofdstuk 17, nr. 13. (1.1.)

93. Veder-Smit, $E$., Toekomstige struktuur gezondheidszorg in Nederland (XII), Medisch Contact, 1971, p. 357-360. (1.1.)

94. Veldkamp, G.M.J., De financiering van de gezondheidszorg op een tweesprong, ECONOMIE, (33), 1968, p. 53-67. (5.4.1.)

95. Vissers, $F$., Regionale facetten van doelmatigheid en strukturering in de klinische gezondheidszorg, in: Herstrukturering van de gezondheidszorg, verslagen voorjaarsstudiedagen 1969 van de Stichting Studiecentrum voor ziekenhuiswetenschappen, Amsterdam, Cloeck en Moedigh, 1969, p. 92-103. (1.1.)

96. Volksgezondheidsnota 1966, Tweede Kamerstukken, zitting 1965-1966, Den Haag, Staatsuitgeverij, 1966. (1.1./5.4.1.)

97. Vreeze, J.T.M. de, Regionale samenwerking van Ziekenhuizen in: Verslagen van symposia Ziekenhuisorganisatie, Groningen, z. uitg., 1967. (1.1.)

98. Vries, $J$. de, De volksverzekering tegen ziektekosten als instrument van financiering en bijsturen, Tijdschrift voor Sociale Geneeskunde, 52, (1974), p. 314319. (1.1.)

99. Wagner, D.J., Aard en taak van het Centraal Orgaan ziekenhuistarieven COZ. Tijdschrift voor Sociale Geneeskunde, (54), 1975, p. 774-779. (5.2.1.)

100. Werner, $F$., Samenvatting van de inleiding voor de studiedag budgettering NZR, Utrecht, z. uitg., 1978. (7.2.1.)

101. Werff, $A$. van der, Organizing health care systems, a developmental approach, Eindhoven, 2. uitg., 1976. (1.2.)

102. Wet Ambulancevervoer, d.d. 23 april 1971, Stb. $1971 \mathrm{nr}$. 369. (5.3.1.)

103. Wet Gezondheidsverzekering, Memorie van toelichting, Medisch Contact, (1975), 30 p. 1164-1183 en Unie, (1975), nr. 7/8. (1.1.)

104. Wet Reorganisatie Binnenlands bestuur. Tweede Kamerstukken 1975-1976, nr. 13.496. (5.1.3.)

105. Wet Tarieven gezondheidszorg, ontwerp van wet, regelen met betrekking tot de tarieven van organen voor gezondheidszorg, Tweede Kamerstukken, 1976$1977,14.182$ nrs. 1-3. (5.3.2.)

106. Wet Voorzieningen gezondheidszorg, ontwerp van wet, regelen ter bevordering van een doelmatig stelsel van voorzieningen voor gezondheidszorg, Tweede Kamerstukken, zitting 1976-1977, stuk 14.181 nrs. 1-4, Den Haag, Staatsuitgeverij, 1977. (1.1.)

107. Wet Ziekenhuisvoorzieningen, 25 maart 1971, Stb. 268, Gewijzigd op 21 dec. 1972, Stb. 773. en Wet Ziekenhuisvoorzieningen 1971 en Memorie van Toelichting, Tweede Kamerstukken, zitting 1967-1968, nr. 9717 en zitting 19691970 , nr. 161, Staatsuitgeverij. (1.1./5.3.1.)

108. Wet Ziekenhuisvoorzieningen, ontwerp van wetswijziging, Staatsblad 1978, nr. 763. (5.3.1.)

109. Wit, G.W. de, Budgettering in de gezondheidszorg, Medisch Contact, nr. 30 , 1975, p. 1659-1662. (1.1.)

110. Wolf, J. van der, De Centrale Raad voor de Volksgezondheid en zijn betekenis voor de gezondheidszorg, Tijdschrift voor Sociale Geneeskunde, (53), 1975, p. 757-762. (5.2.1.)

111. Wijmen, F.C.B. van, Het Ziekenhuis, democratisering en bestuursstruktuur, Lochem, De Tijdstroom, 1975. (5.4.5.2.)

112. Ziekenfondsraad, Advies inzake Wet Voorzieningen Gezondheidszorg en Wet Tarieven Gezondheidszorg, Amstelveen, z. uitg., 1977, nr. 84. (1.2.)

113. Ziekenfondsraad, Discussienota mogelijkheden van budgettering in de gezondheidszorg, Amstelveen, z. uitg., 1978, nr. 94. (1.1./7.2.1./7.2.3.)

114. Ziekenfondsraad, jaarverslag 1977, Amstelveen, z. uitg., 1978. (6.4.3.) 
115. Ziekenfondsraad, rapport van de Commissie-Piket, Amstelveen, z. uitg., 1976, nr. 79. (5.4.2.)

116. Ziekenfondsraad, rapport van de Commissie-Becht, Amstelveen, z. uitg., 1976, nr. 73. (5.4.2.)

117. Ziekenfondsraad, Voorlopige richtlijnen inzake financiële tegemoetkoming multidisciplin aire samenwerkingsverbanden, Amstelveen, z. uitg., 1978, nr. 96. (5.4.4.)

118. Ziekenhuis Bethesda, Verpleeghuis Weidestein, Integratie van eerste- en tweedelijns gezondheidszorg, konsekwenties voor het ziekenhuis Bethesda Hoogeveen, Hoogeveen, z. uitg., 1977. (5.4.4.)

\section{ENGELAND}

119. Accounts 1973-1974, NHS Acts 1946-1968, London, HMSO, 1975. (2.3.)

120. Allocations to RHAs $1977 / 78$, The Hospital and health services review, april 1977, p. 132 . (3.4.3.)

121. Allen, D.E., The development of the 1962 Hospital plan, a case study in decision making, Manchester, z. uitg., 1976. (2.2.)

122. Anderson, O.W., Health care: can there be equity?. the US, Sweden and England, 'Chicago, Willy and Son, 1972. (6.6.2.)

123. Another area cuts a district, editorial, HSSJ, (87), 1978, p. 410. (3.4.4.)

124. Anson, D.C., NHS-Reorganisation - Administrator's stagnation?, $T H H R,(73)$, 1977, p. 426-429. (3.4.5.1.)

125. Ball, David, Tomorrow's world? HSSJ, (86), 1977, p. 1490-1499. (3.4.4.)

126. Ball, David, Interview Colin Harris, HSSJ, (87), 1978, p. 762-763. (3.4.4.)

127. Ball, David, Private Medicine, the bottom line, HSSJ, (87), 1978, p. 572-573. (3.4.5.1.)

128. Blanpain, J. with L. Delesie \& H. Nijs, National Health Insurance \& health resources, The European Experience Cambridge, Massachusetts \& London, 1978. (2.2./4.2.)

129. $B M A$, Report of Council to the Special Representative Meeting, $B M J,(1)$, 1978, p. 299-334. (2.4.1.)

130. Booth, Priorities, edited version of discussions at a one day conference on "Priorities for health and Personal Social Services" and "Prevention and Health; Everybody's Business", BMJ, (I), 1976, p. 1447-1454. (3.4.1.)

131. British Medical Association, Questionnaire to Senior Hospital Staff, $B M J, 7$ dec. $1974,(2)$, p. 608. (2.4.2.)

132. Brown, R.G.S., e.a., New Bottles: old wine?, Humberside reorganisation project, Institute for health studies, University of Hull, Hull, z. uitg., 1975. (3.4.2.)

133. Brown, R.G.S., The changing NHS, London, Routledge \& Kegan Paul, 1978. (2.4.1.)

134. Brunel Institute of Organisation and Social Studies of The Brunel University, Collaboration between Health and Social Services, Uxbridge Middlesex, z. uitg., 1976. (3.4.4.)

135. Butler, J.R. and R. Knight, Designated areas: A review of problems and Policies, $B M J,(2), 1975$, p. 571-573. (2.4.3.)

136. Butler, J.R., Family Doctors and Public Policy, London Routledge \& Kegan Paul, 1975. (2.4.3.)

137. Buxton, M.J. and R.E. Klein, Distribution of Hospital provision: Policy Themes and Recource variation, $B M J,(1), 1975$, p. 345-347. (3.4.1.)

138. Care of the Elderly in Britain, Central office of information reference pamphlet 121, London, z. uitg., 1976. (2.1.2.)

139. Chancellor of the Exchequer, Public Expenditure to 1978-1979, Cmnd 5979, London, HMSO, 1975. (2.1.1.) 
140. Chancellor of the Exchequer, Public Expenditure to 1979-1981, Cmnd 6393, London, HMSO, 1976. (2.1.1.)

141. Chancellor of the Exchequer, Public Expenditure to 1980-1982, Cmnd 1234, London, HMSO, 1976. (2.1.1.)

142. Chancellor of the Exchequer, The Government's Expenditure Plans, 19781979 to 1981-1982, Cmnd 7049-I en 7049-II, London, HMSO, 1978. (3.4.2.)

143. Chester, David, Can the health service afford to manage like this? $H S S J,(87)$, 1978, p. 451-452. (3.4.4.)

144. Chester, T.W., One year later - impressions and reflections, THRR, (71), 1975, p. 117-121. (3.4.5.1.)

145. Chester, T.E., Social change and NHS - reorganisation, THHR (72), 1976, p. 201-204 en p. 230-233. (3.4.5.1.)

146. Confusion as Moyle tells of Rawp Gloom, editorial, HSSJ, (86), 1977, p. 916. (3.4.3.2.)

147. Cook, Paula J. and R.O. Walker, The geographical distribution of dental care in the United Kingdom, British Dental Journal, May 16, June 6 and June 20, 1967 , p. 441 , p. 494 en p. 551 . (2.4.3.)

148. Cooper, M.H., Rationing Health Care, London, Croom Helm, 1975. (2.4.1.)

149. Cooper, M.H. and A.J. Culyer, An economic survey of the nature and intent of the British National Health Service, Social Sciences and Medicine (V), 1971, p. 1-13. (2.4.3.)

150. Cooper, M.H. and A.J. Culyer, Equality in the National Health Service, Intensions, Performance and problems in evaluation in: The economics of medical care, London, Allen \& Unwin, 1972. (2.4.3.)

151. CSO, Monthly Statistics, 1975-1978, London, HMSO, 1975-1978. (2.1.1.)

152. CSO, The Registrars General Statistical review of England and Wales, 1950, London, HMSO, 1950. (2.1.2.)

153. CSO, Annual Abstracts of Statistics (1977), London, HMSO, 1978. (2.1.1.)

154. CSO, National Income and Expenditure 1966-1976, London, HMSO, 1977. (2.1.1.)

155. Crisis of confidence in NHS, editorial, $B M J,(2), 1976$, p. 250. (3.4.5.1.)

156. Crossman, R.H.S., Inside view, three lectures on Prime Ministerial Government, London, Jonathan Cope, 1972. (2.4.2.)

157. Crossman, R.H.S., A Politician's View on Health Service Planning, Glasgow, 1972. (3.4.3.2.)

158. Culyer, A.J. and J.G. Cullis, Hospital waiting lists, New Society, 1973, p. 393395. (2.4.1.)

159. Culyer, A.J., Need and the NHS, London, Martin Robertson, 1976. (2.4.1.)

160. DHSS, A hospital plan for England and Wales, Cmnd 1604, London HMSO, 1962. (2.4.2.)

161. DHSS, Cash limits for health authorities, London, z. uitg., 1978. (3.4.3.)

162. DHSS, First Interim Report of the Resource Allocation working party: allocations to regions 1976/1977, London, 1975. (3.3.2.1.)

163. DHSS, First Report of the Joint Working Party on the Organization of Medical Work in Hospitals, London, HMSO, 1967 (Second Report: 1972 en Third Report: 1974). (3.2.)

164. DHSS, Health and Personal Social Services for England, 1976, London, HMSO, 1977. (2.1.1.)

165. DHSS, Health Services management review of management costs, health circular (77) 10, London, z. uitg., 1977. (3.4.2.)

166. DHSS, Management Arrangements for the reorganised National Health Service, London, HMSO, 1972. (3.2.)

167. DHSS, NHS Reorganization, Cmnd 5055, London, HMSO, 1972. (3.1.)

168. DHSS, Overspending by Lambeth, Southwark and Leursham AHA (T), letter by Mr. David Ennals, Secretary of State for Social Services, to chairman of AHA. (3.4.3.2.) 
169. DHSS, Prevention and Health, Everybody's business, a consultative document, London, HMSO, 1976. (3.4.1.)

170. DHSS, Priorities for health and Personal Social Services in England, a consultative document, London, HMSO, 1976. (2.1.2.)

171. DHSS, Regional allocations, $1976 / 77$, London, z. uitg., 1976. (3.4.3.)

172. DHSS, Regional Chairman's Enquiry into the working of the DHSS in Relation to RHA, London, z. uitg., 1976. (3.3.1.)

173. DHSS, Resource Allocation Working Party, $(R A W P)$, Sharing resources for health in England, London, HMSO, 1976. (3.3.2.1.)

174. DHSS, The Administrative Structure of Medical and Related Services in England and Wales, a consultative document, London, HMSO, 1968. (2.4.4.)

175. DHSS, The future of the NHS, a consultative document, London, HMSO, 1970. (3.1.)

176. DHSS, The NHS - Planning System, London, z. uitg., 1976. (3.3.1.)

177. DHSS, The NHS-reorganized, a consultative document, London, HMSO, 1971. (3.1.)

178. DHSS, The way forward, London, HMSO, 1977. (3.4.1.)

179. Dixon, J.C., Resource allocation in the NHS. Public Finance and Accountancy, 1976, p. 213-216. (3.4.3.1.)

180. Dyson, $R$., The Liverpool inquiry, $B M J$, (I), 1978, p. 383-384. (3.4.3.2.)

181. East Anglian $R H A$, Draft Strategic Plan for health services $1977-1982$, z. uitg., 1977. (3.4.1.)

182. Edwards, B. \& P.R. Walker, Si vis pacem, Preparations for change in the NHS, London, Oxford University Press, 1973. (3.4.5.1.)

183. Eskin, F. \& P. Newton, A survey of public knowledge in relation to the National Health Service reorganization, Community Health, (9), 1977, p. 114119. (3.4.5.1.)

184. Enoch Powell, J., Medicine and Politics; 1975 and After, London, Pitman Medical, 1976. (2.4.2.)

185. Fear of further Hospital cut back, The Guardian, Saturday, 1976, November 27. (3.4.3.2.)

186. Fair shares, editorial, THHR, (71), 1975, p. 413-414. (3.4.3.1.)

187. Falling standards and Sagging Morals, editorial, BMJ, (1), 1975, p. 675-676. (3.4.5.1.)

188. Forsyth, J.M., e.a., The London hospitals scene, correspondence, BMJ, (2), 1976, p. 1320-1321. (3.4.1.)

189. Gentle, P.H. \& J.M. Forsythe, Revenue Allocation in the reorganized Health Service, $B M J,(3), 1975$, p. 382-384. (3.4.1.)

190. Godber, G.E., The British NHS, Washington, US Department of Health Education and Welfare, No. (NIH) 77-1205, 1976. (2.4.1.)

191. Godber, G.E., Fair shares in the NHS, The Lancet, 1976, p. 622-624. (2.4.4.)

192. Griffiths, D.A.J., Inequalities and management in the NHS, The Hospital, (67), 1971. (2.4.3.)

193. Hallas, J., CHC's in action, A review, London Nuffield Provincial Trust (1976). (3.4.5.2.)

194. Hampshire AHA (T), Programmes 1976-'77, Southampton, z. uitg., 1976. (3.4.1.)

195. Institute of Health Services Administrators, Evidence to the Royal Commission, THHR , (73), 1977, p. 161-162. (3.4.4.)

196. Jeffries, M., RAWP and the Oxford Region I, II and III, $B M J(1), 1978, \mathrm{p}$. 426-427, 495-496 en 638-639. (3.4.3.2.)

197. Jones, D. \& A. Bourne, Monitoring the Distribution of Resources in the NHS, Social and Economic Administration, (10), 1976, p. 92-105. (3.4.3.1.)

198. Jones, Sir Francis Avery, The London hospital scene, $B M J,(2), 1976$, p. 10461049. (3.4.3.1.) 
199. Joules, H. e.a., The London hospital scene, ingezonden brieven, $B M J,(2), 1976$, p. 1251-1253. (3.4.3.2.)

200. Klein, $R$., Resource allocation, $T H H R$, (73), 1977, p. 280-284.(3.4.3.1.)

201. Klein, $R$., The politics of redistribution, $B M J,(2), 1976$, p. 893-895. (3.4.3.2.)

202. Klein, $R$., Reorganization: what went wrong?, New Society, 1977, p. 592-593. (3.4.5.2.)

203. Lee Donaldson Associates, UK Private Medical Care, Provident Schemes Statistics, 1975, London, z. uitg., 1976. (1.3.3.)

204. Leicester $A H A(T)$, South West Leicestershire Health District Profile, Leicester, z. uitg., 1976. (3.4.1.)

205. Levitt, $R$., The reorganized national health service, London, Croom Helm, 1976. (2.2.)

206. Local Government in Britain, London, British information Services, R. 5055/ 75. (2.1.3.)

207. Maxwell, H.J., Health care, the growing dilemma, London, MCKinsey \& Cie, 1974. (6.6.2.)

208. Maynard, A., Inequality in psychiatric care in England and Wales, Social Sciences \& Medicine, (6), 1972, p. 221-227. (2.4.3.)

209. Medical Services Review Committee, A review of the Medical Services in Great Britain (Poritt Report), Social Assay, London, 1962. (2.4.4.)

210. NHS-Act 1946. (2.2.)

211. NHS Private Beds, Summary of Events, BMJ, (3), 1974, p. 127-128. (3.4.5.1.)

212. Newbould, Gerard $D$., Comparison of medical and industrial salaries in the UK 1965-1976, $B M J$, (1), 1977, p. 526-527. (3.4.5.1.)

213. Next year's Money for the NHS, lancet, vol. 1 no. $8112,17-2-1979$, p. 393. (3.4.3.)

214. Noyce, J., A.H. Snaith \& A.J. Trickey, Regional Variations in the Allocation of Financial Resources to the Community Health Services, The Lancet, 1974, p. 554-557. (2.4.3.)

215. Office of Health Economics, Compendium of health statistics, London, z. uitg., 1977. (2.4.1.)

216. OPCS-Monitor, Mid-1971 to mid-1977 population estimates for health areas. (3.4.3.)

217. Owen, D., Towards a unified health service, THHR, (70), 1974, p. 242-244. (2.4.4.)

218. Owen, $D$., In sickness and in health, London, Quartet Books, 1976. (2.4.2.)

219. Oxford, $R H A$, Report on the Management Functions of the Regional and Area Health Authorities, Oxford, z. uitg., 1977. (3.4.4.)

220. PEP-committee, Report on the British Health services, 1937. (2.2.)

221. Problems of NHS planning, editorial, $B M J,(2), 1977$, p. 214. (3.4.1.)

222. Rathod, N.H., Redistribution of resources, BMJ, (4), 1975, p. 522. (3.4.1.)

223. Resources and their allocation, editorial, THHR, (73), 1977, nr. 2 p. 59-61. (3.3.2.1.)

224. Richard, J.H., The allocation of revenue expenditure between areas in the reorganized health service, Oxford, University, z. uitg. 1974. (3.4.1.)

225. Richard, J.H., Talking point: Per capita expenditure of the English area health authorities, $B M J$, (1), 1976, p. 299-300. (3.4.1.)

226. Rippington, $T$. Being on the right side of RAWP after three years, $H S S J$, (87), 1978, p. 277-278. (3.4.3.2.)

227. Roelens, A., Van desintegratie naar in tegratie in de Engelse Nationale Gezondheidsdienst, Katholieke Universiteit Leuven, School voor maatschappelijke gezondheidszorg, z. uitg., Leuven, 1974. (2.2.)

228. Royal College of General Practitioners, Evidence to the Royal Commission on the NHS, London, z. uitg., 1976. (3.4.4.)

229. Royal Commission on the NHS, Allocating health resources: a commentary, research paper nr. 3, London, HMSO, 1978. (3.4.3.2.) 
230. Royal Commission on the NHS, The management of financial resources in the NHS, research paper nr. 2, London, HMSO, 1978. (3.3.1.)

231. Royal Commission on the NHS, The Task of the commission, London, HMSO, 1976. (3.4.4.)

232. Royal Commission on the NHS, The working of the NHS, research paper nr. 1, London, HMSO, 1978. (3.4.4.)

233. Royal Commission on the NHS, Report of the Royal Commission on the NHS, Cmnd 7615, HMSO, London, 1979. (3.4.4.)

234. Ryan, M., The Royal Commission on the NHS, Origins and Prospect, Social and Economic Administration, (11), 1977, p. 194-205. (3.4.4.)

235. Salisbury Health Districts, Wiltshire AHA, District Plan, 1979-'80 to 1981-'82. (3.4.1.)

236. Social Insurance and Allied Services, (Report by Sir William Beveridge), Cmnd 6502, London, HMSO, 1942. (2.2.)

237. Southampton S.W. Hants Health District, District profile and district plan 1975, Southampton, z. uitg., 1975. (3.4.1.)

238. South Western Regional Strategic Plan, Regional Strategic Plan, 1977 - 1986. (3.4.1.)

239. Stockport AHA, Area Strategic Plan 1977-1986, Stockport, z. uitg. 1976. (3.4.1.)

240. United Nations Organization, Demographic Yearbook 1952, 1975, New York, 1952 en 1975 . (2.1.1.)

241. Vandewalle, G., Groot-Brittannië op weg naar financieel herstel!, Economisch Statistische berichten, 1977, p. 532-536. (2.1.1.)

242. Wessex, RHA, Summary of the Strategic Plan 1978-'79 to 1987-'88. (3.4.1.)

243. Wessex, RHA, Policy Review, Revenue Resource Allocation, Winchester, z. uitg., 1975. (3.4.3.1.)

244. West, P.A., Allocation and Equity in the public sector: the hospital revenue allocation formula: Applied Economics, 1973, (5), p. 153-166. (3.4.3.1.)

245. West, P.A., Equity in Health Service Provision, the formula approach, Social and Economic Administration (10), 1976, p. 83-105. (2.3.)

246. What a RAWP-roar, editorial, $B M J$ (2), 1976, p. 1280. (3.4.1.)

247. Winifred Raphael, Patients and their hospitals, London, King's Fund College, 1975. (2.4.5.)

248. Winifred Raphael, Psychiatric hospitals viewed by their patients, London, King's Fund College, 1976. (2.4.5.)

\section{ZWEDEN}

249. Berfenstam, $R$., Swedish medical care in the 1980's, ways and means, Stockholm, z. uitg., 1973. (4.2.)

250. Björk, $S$., Overbelaggningar ger dålig vardmiljöcoch försämrad patientvärdnad, Tss, (43), 1976, nr. 9. (4.4.5.1.)

251. Borgenhammer, E., Budgeting medical services, Götenburg, 1979, ter perse. (4.2.)

252. Björk, S., Sabbatsberg inspekterades av socialstyrelsen, Tss, (43), nr. 3, 1976. (4.4.5.1.)

253. Björk, S., Sabbatsberg inspekterades av socialstyrelsen, Tss, 1976, (3), p. 4-5. (4.4.5.1.)

254. Borgenhammar, E., Problemanalys och förslag till förbattringar, Nordisk Medecin, 91, 1976. (4.3.2.)

255. Brody, Prof. S., Centralisering och analys av "spin-off-effeter" sparar mer än klinikchefers kostnadjäht, Nordisk Medecin, (91), 1976. (4.3.2.)

256. Budgetdepartementet, Kommunernas ekonomi 1975-1985, Stockholm, SOU, 1977. (4.4.2.) 
257. Clade, Dr. Harald, Das Sieben Kronen Debakel, Arbeit und Sozialpolitik, 1974. (4.4.1.)

258. Crafoord, Clarence, So verändert sich die psychiatrische Krankenpflege in Schweden, Aktuelle Informationen aus Schweden, (114), 1976. (4.2.)

259. $C R V$, Regionalisatie en overheidsbeleid in de Zweedse gezondheidszorg, Den Haag, Staatsuitgeverij, 1976. (4.4.3.)

260. Dahlin, $L$., En befolkningsstudie i tre Malmö-distrikt som bakgrund vid planering av öppenvården, Läkartidningen (74), 1977. (4.4.1.)

261. Docter-de Leeuw, Drs. W., Acht ziekenhuizen in Zweden, verslag van een studiereis, Utrecht, NZR, z. uitg., 1976. (4.2.)

262. Egelstedt, Ingemar, The health delivery system in Sweden, Stockholm, Landstingförbundet, $z$. uitg., 1977. (4.3.2.)

263. Ejlertsson, G., Kontinutet och tild värderas högt De unga ställer höga krav, Nordisk Medecin, (91), 1976. (4.4.5.1.)

264. Ejlertsson, G., Attitudes towards medical care among the Dalby population, Dalby Days, z. uitg., 1976. (4.4.5.1.)

265. Engel, Arthur, Perspectives in Health Planning, London, 1968. (4.2.)

266. Greve, Drs. W.B. de en Prof. Dr. H.K.A. Visser, Professie en management in het ziekenhuis, Medisch Contact (33), 1978. (4.3.2.)

267. Hjern, Bo, The Swedish health services from the standpoint of the professionNegotiating and Bargaining, Chicago, z. uitg., 1976. (4.4.5.1.)

268. Juda, D., Planning for scarcity in Sweden, Hastings Center Report, 1977. (4.4.2.)

269. Karlson, Willy, The Tierp Project - Its objectives, organization and fields of activity I en II, National Board of Health and Welfare Stockholm, z. uitg. 1977. (4.4.4.)

270. Karlsson, $Y$., Politiker vill ge klinikchefer större ekonomisk rörelsefriket, Nordisk Medecin (92), 1977. (4.4.2.)

271. Landstingförbundet, County Council; Perspectives, 1975-1979, Future medical care up for debate, Stockholm, z. uitg., 1975. (4.4.2.)

272. Landstingförbundet, The Federation of Swedish County Councils, an organization for the common problems and tasks of 23 county councils, Stockholm, z. uitg., 1976. (4.1.3.)

273. Landstingförbundet, Health and Medical Care services, the county councils in Sweden, 1973. (4.4.2.)

274. Landstingförbundet, Organisationskatalogen 1977, Stockholm, z. uitg., 1977. (4.2.)

275. Landstingförbundet, Statistisk årsbok för landsting, 1977, Stockholm, z. uitg., 1977. (4.3.2.)

276. Landstingförbundet en Socialstyrelsen, County Councils Plan 1975-1981, Stockholm, z. uitg., 1977. (4.3.1.)

277. LATT, Läkares arbetstider och tjänster 1977, Del 1 en 2, Stockholm, z. uitg., 1978. (4.3.1.)

278. Lapré, R.M., De regionalisatie van de Zweedse gezondheidszorg, Het Ziekenhuis, (4), 1975. (4.4.1.)

279. Lithman, T. en B. Schersten, Kan primärvården överta 20 procent av appenvardsbesöken på sjukhus? Nordisk Medecin, (91), 1976. (4.4.1.)

280. Löfgren, Inger en Bo, Die Schweden und der Alkohol, Aktuelle Information aus Schweden, (105), Stockholm Swedish Institute, 1976. (4.1.2.)

281. Malmöhus läns landsting, Förslag till Flerårsplan 1979-1983, Malmö, z. uitg., 1978. (4.3.2.)

282. Mårtens, A., Förbättra sommarsituationen nu!, Tss, (43), 1976. (4.4.5.1.)

283. Ministry for Economic Affairs, The Swedish Economy 1977, prospects and policies, A summary of the Budget Statement, Stockholm, SOU, 1977. (4.1.1.)

284. Ministry of the Budget, The Swedish Budget 1976/77, 1977/78 en 1978/79, Stockholm, SOU, 1976, 1977 en 1978. (4.1.1.) 
285. Ministry of Economic Affairs, The Swedish Economy, January 1978, Stockholm, SOU, 1978. (4.1.1.)

286. Monvall, E., Landsniget i Örebro län attacherar sjukskotersskebristen, $T s s$, (43), 1976. (4.4.5.1.)

287. Mosten, K.E., Privatpraktiserande Läkare, Föredragning inför Hälso och sjukvärdsutredningen den 17 mars 1977, Stockholm, z. uitg., 1977. (4.2.)

288. Navarro, V., National and regional health planning in Sweden, Washington, US DHEW-publication (NIH) 74-240, 1974. (4.1.3.)

289. Nelissen, $R . J$., De economie van Nederland vergeleken met $Z$ weden en Duitsland, Maatschappij Belangen, (33), 1977. (4.1.1.)

290. Nicolausson, U., Primärvårdens innihål och ansvar bör ändras successivit, Nordisk Medecin (92), 1977. (4.4.1.)

291. Nicolausson, U., The place of primary health care centers in the health delivery system in Sweden and the education of the health care team, Stockholm Socialstyrelsen, z. uitg., 1977. (4.2.)

292. Organization of Economic Cooperation and Development, Economic Survey: Sweden, Paris, z. uitg., 1977. (4.1.1.)

293. Rexed, B., How Sweden plans for the 1980s, in: Ehrlich D.A. (ed), The health care cost explosion, which way now?, Bern, 1975. (4.4.2.)

294. Socialdepartementet, Budgetpropositionen 1977, Bilage B, Riksdagen 1976, 1 saml nr. 100, Stockholm SOU, 1976. (4.2.)

295. Socialdepartementet, Rapport till nordiska socialpolitiska ministermötet i Ronneby 1977 om den svenska socialpolitiken ären 1975-1977, Dss 1977:5, Stockholm, z. uitg., 1977. (4.1.2.)

296. Socialstyrelsen, Abstracts from Public Health in Sweden 1974, Stockholm, z. uitg., 1975. (4.1.2.)

297. Socialstyrelsen, Förslag till Läkarfördelningsprogram för perioden 1979 - 1982, Stockholm, z. uitg., 1977. (4.3.1.)

298. Socialstyrelsen, Sjukvårds Huvudmännens planer till 1985, Redovisar 1976, nr. 7, Stockholm, z. uitg., 1976. (4.3.1.)

299. Socialstyrelsen, Statistika Meddelanden, Stockholm, 1977 en Statistika uppgifter från vårdplaneringsliste, Stockholm, 1977. (4.4.1.)

300. Socialstyrelsen, The Swedish health services in the eighties, Stockholm, z. uitg., 1976. (4.2.)

301. SPRI, Sjukvårdshuvudmånnens planer till 1985 - sammanställning i siffror, 1976, rapport 5, Stockholm, z. uitg. 1977. (4.3.1.)

302. SPRI, The organization of out-patient care, Stockholm, z. uitg., 1972. (4.2.)

303. Stähl, Ingemar, Planering - ett styrmedel?, Rede uitgesproken op het congres van de Landstingförbundet in Sundsvall op 14 en 15 juni 1978, Lund, z. uitg., 1978. (4.4.1.)

304. Stähl, I., Health costs and expenditures in Sweden, the problem of a private good in the public sector, in: (6.6.2.)

305. Swedish Commission en Social Welfare, Social welfare: end and menas, Current Sweden, 54, Stockholm Swedish Institute, 1974. (4.4.4.)

306. Swedish Medical Association, SMA and Health in Sweden, Stockholm, z. uitg., 1976. (4.2.)

307. SOS, Allmän hälso- och sjukvård, 1950 t/m 1975, Stockholm, 1951 - 1977. (4.2.)

308. SOS, National Accounts 1970-1976, N 1977:7.4, Stockholm, SOU, 1977. (4.1.1.)

309. SOS, Statistik årsbok för Sverige 1955, 1960, 1977, Stockholm, SOU, 1956, 1961 en 1978. (4.1.1.)

310. Tottie, $M$. en $B$. Janzon, Regional Hospital Planning, Current trends in health services, Stockholm, Socialsty relsen, z. uitg., 1970. (4.2.)

311. Uppsala län landsting, Handlingar till möte 14-18-11-1977, Uppsala, z. uitg., 1977. (4.3.2.) 
312. Wennström, G., The public health planning system in Sweden, Stockholm Socialstyrelsen, z. uitg., 1974. (4.3.2.)

313. Wetterberg, U. en J. Hjertqvist, Kommunerna inför 80 -talet, Stockholm, SOU, 1977. (4.4.2.)

314. Wictorson, K.E., Public Health Planning, Stockholm Socialstyrelsen, z. uitg., 1977. (4.4.2.) 


\section{LIJST VAN GERAADPLEEGDE PERSONEN}

\section{NEDERLAND}

Aert, J.J. van, College voor Ziekenhuisvoorzieningen, Utrecht.

Amstel, J., Ministerie van V \& M, afdeling verzekeringen, Den Haag.

Blox, J.T.M., Vakgroep economie van de T.H. Eindhoven.

Dokter-de Leeuw, W., Nationale Ziekenhuisraad, Utrecht.

Dolman, D., Voorzitter Tweede Kamer-commissie voor de Volksgezondheid, Den Haag.

Heide, H. ter, Hoogleraar T.H. Delft, vice-voorzitter COZ.

Iden burg, Ph.A., Voorzitter Harmonisatieraad, Den Haag.

Kalff, D.J.A., Wetenschappelijk medewerker T.H. Delft.

Lapré, R.M., Secretaris Centrale Raad voor de Volksgezondheid, Den Haag.

Leenen, H.J.J., Hoogleraar Sociale Geneeskunde, Universiteit van Amsterdam.

Montfort, G. van, Nationaal Ziekenhuis Instituut, Utrecht.

Raymakers, C., Ziekenfondsraad.

Rosenberg, H., Wethouder Financiën, Gemeente Utrecht.

Schnerr, J.W., Ministerie van V \& M, sektie planning en bouw, Den Haag.

Vries, J. de, Secretaris Vereniging van Nederlandse Ziekenfondsen.

Vijsel, A. van der, College voor Ziekenhuisvoorzieningen, Utrecht.

Werff, A. van der, Ministerie van V \& M, Hoofd stafafdeling beleidsontwikkeling.

Werner, J., Ministerie van V \& M, hoofd afdeling Verzekeringen.

\section{ENGELAND}

Adams, G.D., District Administrator, North Hammersmith district, London.

Akehurst, R.L., DHSS, London.

Auckland, Alastair, Area Planner, Hampshire AHA (T), Winchester.

Beach, I., District Administrator, S.W. Leicester Health District, Leicester.

Brice, A., Chairman Medical Executive Committee, Southampton.

Buxton, M.J., Centre for Studies in Social Policy, London.

Carter, T.W.i., General Practitioner District Management Team North Hammersmith, District London.

Callingham, M., Assistant district treasurer, Southampton and S.W. Hampshire district, Southampton.

Catterall, J., District Treasurer, Southampton and S.W. Hampshire health district, Southampton.

Clark, T., Medical Services, Southampton and S.W. Hampshire Health District, Southampton.

Culyer, A.J., Assistant Director of Institute of social and economic research, York.

Cunningham, R.L., Royal Commission on the NHS, London.

Dawe, B., District community physician, Southampton and S.W. Hampshire health district, Southampton.

District Management Team, S.W. Leicestershire health district, Leicester.

Dorward, A., Treasurer's Department, Southampton and S.W. Hampshire District, Southampton.

Drummond, M.F., Institute of Social \& Economic Research, University of York, Heslington, York. 
Drummer, A., Regional Development Department, Wessex Region, Winchester.

Finnis, D., Senior Surgical Registrar, Southampton General Hospital, Southampton.

Fourness, B., Circular and Handbook Publishing Unit, DHSS, London.

Gravelle, H.S.E., Economics Department, Queen Mary College, Mile End Road, London, E.I.

Griffiths, A., London School of Hygiene.

Griffiths, P., Assistant District Administrator, Southampton and S.W. Hampshire District, Southampton.

Hands, D., Brunel University.

Herbert, B., Area Treasurer, Ealing, Hammersmith and Hounslow AHA, London.

Hinton, A., Regional Development Department, Wessex Region, Winchester.

Jones, Miss. W., Department of Social Services, London Borough of Hammersmith, London.

Kirby, C.J., Service Planner Wessex Regional Health Authority, Winchester.

Lee, K., Nuffield Centre for Health Services Studies, Leeds.

Lester, Miss J., Senior Administrative Assistant, Hammersmith District, London.

Lindon, R., Area Medical Officer, Ealing, Hammersmith and Hounslow AHA (T), London.

Longdon, D., Assistant Treasurer, S.W. Leicestershire Health District, Leicester.

Mallett, H., Administrator to the Family Practitioner Committee, Leicester.

Marlow, D., Area Administrator, Ealing, Hammersmith and Hounslow AHA.

Matthews, W.R., Area Treasurer, Mid Glamorgan Health Authority, Cardiff, Wales.

McCarthey, M., District Community Phy sician, North Hammersmith District, London.

Mills, A., Nuffield Centre for Health Services Studies, Clarendon Road, Leeds, ISI 9PL.

Morton, A., Director King's Fund Centre, London.

Mullen, $P$., Health Services Management Centre, University of Birmingham.

Nicholls, B., District Administrator, Southampton and S.W. Hampshire district, Southampton.

Pantall, J., Manchester Business School, Manchester.

Pole, J.D., Treasury Chambers, Parliament Street, London, SWIP 3 AG.

Punt, K., Area Treasurer Leicestershire AHA (T), Leicester.

Reeves, Director King's Fund College, London.

Rigden, M., Regional Treasurer, Trent Regional Health Authority, Sheffield.

Roberts, R., South Glamorgan Health Authority, Cardiff, Wales.

Shaw, J., Administrator to the Family Practitioner Committee, Winchester.

Steiner, R., Consultant Member, District Management Team, North Hammersmith District.

Sully, J., Area Planning and Information Officer, Ealing, Hammersmith and Hounslow AHA (T), London.

Taylor, C.G., Assistant Secretary, Finance Division, DHSS, London.

Taylor, D., Assistant-director Office of Health Economics, London.

Taylor, S., Area Treasurer Hampshire AHA, Winchester.

Taylor, W., District Treasurer, W.W. Leicestershire Health District, Leicester.

West, P., School of Social Sciences, Sussex.

Williams, A., Institute of Social and Economic Research, York.

Wright, K., Institute of Social \& Economic Research, University of York, Heslington, York.

\section{ZWEDEN}

Äberg, L., directeur Uppsala Län Landsting.

Annerstedt, bureau internationale kontakten van de Socialstyrelsen.

Berfenstam, R., Institution of Social Medecin, Akademiska Sjukhuset, Uppsala.

Borgenhammar, E., Hoofd van een van de vijf Stockholmse districten. 
Brody, S., Gynaecoloog, Huddinge Hospital, Stockholm.

Carlsson, $L$., Hoofd afdeling begrotingen van het academisch ziekenhuis te Uppsala.

Egelstedt, I., Landstingförbundet, afdeling economische zaken.

Ehrenborg, G., Particulier chirurg, Stockholm.

Falkhede, R., Landstingförbundet, afdeling economische zaken.

Granath, A., arts, Hoofd van het klinisch-chemisch laboratorium van het Danderyd's Hospital.

Hedsund, G., Hoofd afdeling begrotingen, Malmöhus Län Landsting Lund.

Hogberg, G., Hoofd algemene afdeling van het SPRI.

Krakau, I., Districtsarts te Stockholm.

Kolmodin, G., Wetenschappelijk medewerker, neurologische kliniek Danderyd's Hospital.

Lennmarker, G., Afdeling voorlichting Ministerie voor Gezondheid en Sociale Zaken.

Mosten, K.E., Sveriges Lakarförbund.

Nicolausson, U., Socialstyrelsen, Division for Community Health.

Norberg, Ch., Hoofd financiële zaken, Norrbottens Län Landsting, Luleå.

Nordlander, N.B., Arts en raadslid voor de liberale partij van de raad van de Landsting van Uppsala.

Nygren, I., Hoofd afdeling Health and Medical care van het Ministerie voor Gezondheid en Sociale zaken.

Ohisen, A., Deputy Chief Physician van de Medical Clinicvan het Danderyd's Hospital.

Ostgren, L., Hoofd van de afdeling algemene zaken van het academisch ziekenhuis te Uppsala.

Person, E., Internist, Södersjukhus te Stockholm.

Diverse medewerkers van de financiële afdelingen van de landsting Södermanland.

Stahl, I., Department of Economics, University of Lund.

Scenson, A., Uppsala Län Landsting.

Tottie, M., Hoofd afdeling internationale kontakten van de Socialstyrelsen.

Kristin, A., Psy chiater, Södersjukhus te Stockholm.

Wahlqvist, T., Voorlichter van de Landsting Södermanland. 


\section{TREFWOORDENREGISTER*}

Academische regio's, 7.1.

Act, 2.1.3.

Advisory-machinery, 3.2.

Agency arrangements, 3.3.2.2.1.

Aktiviteiten, 1.3.1.

Aktiviteiten van de arts, 2.3.

Aktiviteitenpakket, 1.3.3.

Alcoholisme, 4.1.2.

Algemene Fonds Bijzondere Ziektekosten, 5.3.2.

Algemene Wet Bijzondere Ziektekosten, 5.3.2.

Algemene ziekenhuizen, 4.4.1.

Annual Votes, 2.1.3.

Appropriation account, 2.1.3.

Arbeidsplaatsen, 1.3.1.

Area boards, 2.4.4.

Area health authorities, 3.2.

Areateam officers, 3.2 .

Artsenposten, 4.2.

Begroten, 1.3.3., 7.2.1.

Begroting, 1.3.3., 7.2.1.

Beroepsbeoefenaar, 1.3.3.

Beslissen, 1.3.3.

Besluiten, 1.3.3.

Bestek '81, 5.1.1.

Betrokkenheid, 1.3.1.

Beveridge-report, 2.2 .

Bill, 2.1.3.

Blokkenstruktuur, 4.2 .

Board of Governors, 2.2.

Boroughs, 2.1.3.

Bouwplafond, 5.4.2.1.

Brits, 1.3.3.

Britse begrotingsjaar, 2.1.3.

Budget, 1.3.3., 7.2.1.

Budgetfinanciering, 1.3.3., 7.2.1.

Budgethouder, 3.3.1.

Budgetsysteem, 7.2.1.

Budgetteren, 1.3.3., 7.2.1.

Budgettering, 1.3.3., 7.2.1.

Case-load factor, 3.3.2.1.

Cases, 2.3.

Cash control, 2.1.1.

Cash limits, 2.1.1.

Centers of excellence, 3.3.2.2.2.

Centraal orgaan gezondheidszorg tarieven, 5.3.2.

Centraal orgaan Ziekenhuistarieven, 5.2.1.

Central manpower committee, 3.3.1.

Centrale Raad voor de Volksgezondheid, 5.2.1.

* Aangegeven is de paragraaf, waar een begrip wordt geintroduceerd. 
Centrallasarett, 4.2 .

Chairman district medical committee, 3.2.1.

Chairman of division, 3.3.1.

Chancelor of the Exchequer, 2.1.3.

Chirurgisch blok, 4.2 .

Client group, 3.4.1.

Cogwheel reports, 3.2 .

Collectieve voorzieningen en de werkgelegenheid (Nota), 5.1.1.

College van Ziekenhuisvoorzieningen, 5.2.1.

Command, 2.1.3.

Community Health Councils, 3.2 .

Comprehensive gezondheidszorg, 2.2 .

Consensusprincipe, 3.2 .

Consultative document, 2.1.3.

Continuiteit, 1.3.1.

Counties, 2.1.3.

Cottage-hospitals, 6.3.

Cross boundary flows of patients, 3.3.2.2.1.

Denominatie, 5.2 .

Department of health and social security, 2.2.

Designated area, 2.3.

Dienstencentra voor bejaarden, 1.3.3.

Discussion on the budgets, 2.1.3.

Districts, 3.2.

District administrator, 3.2.1.

District catering officer, 3.2.1.

District community physician, 3.2.1.

District finance officer, 3.2 .1 .

District general hospital, 2.4.2.

District management team, 3.2 .

District Nurse Officer, 3.2.1.

District Plan, 3.2.1.

District superintendant radiographer, 3.2.1.

District treasurer, 3.2.1.

Distrikten, 4.2.

Distriktsartsen, 4.2.

Distriktsverpleegkundigen, 4.2.

Distriktsziekenhuizen, 4.2 .

Echelonnering, 5.2.2.

Echelons, 4.2.

Eenheid van bestuur, 2.4.4.

Eén-procentsoperatie, 5.4.2.3.

Eerstelijnsblok, 4.2.

Eerstelijnsgezondheidszorg, 1.3.3.

Eerstelijnsvoorzieningen, 1.3.1.

Egalisatiesysteem, 4.3.2.

Emergency Medical Service, 2.2.

Engels, 1.3.3.

Evenwichtige geografische spreiding, 1.3.1.

Evidences, 2.1.3.

Executive council, 2.2.

Exploitatiebudget, 3.3.2.2.

Externe budgettering, 7.2.1. 
Family practitioners Committee, 3.2.

Fee-forservice system, 7.2.1.

Financiële middelen, 1.3.1.

Financiering, 1.3.3.

Financiering op basis van tarieven, 1.3.3.

First green paper, 2.4.4.

Forsäkrungstyrelsen, 4.1.3.

Funding, 7.2.1.

Funktie, 1.3.3.

Funktiepakket, 1.3.3.

Funktioneel, 1.3.3.

Funktionele financiering, 7.2.3.

Funktionele organisatie, 3.2.1.

Gemeente Amsterdam, 5.3.1.

Gemeenten, 5.1.3.

General Household Survey, 3.4.3.1.

Gesloten budget, 1.3.3.

Gezondheidsraad, 5.2.1.

Gezondheidszorg, 1.3.3.

Greater London, 2.1.3.

Greater London Council, 2.1.3.

Green paper, 2.1.3.

Grensoverschrijdend patiëntenverkeer, 3.3.2.2.1.

Groot Brittannië, 1.3.3.

Guillebaud-report, 2.4.2.

Health care planning teams, 3.2.1.

Health Economic Study Group, voorwoord

Health profile, 3.4.1.

Health services, 1.3.3.

Health visitors, 2.4.1.

Hospital activity analysis, 3.3.2.2.1.

Hospital management committees, 2.2 .

Hospital plan, 2.4.2.

House of Commons, 2.1.3.

House of Lords, 2.1.3.

House's select Committee on Expenditure, 2.1.3.

Icing on the cake, 2.3 .

Independant contractors, 2.2 .

Indexfinanciering, 7.2.1.

Infrastruktuur, 2.3.

Inputfinanciering, 7.2.1.

Inspraak, 1.3.1.

Instelling, 1.3.3.

Instituut voor $Z$ iekenhuiswetenschappen, voorwoord

Integratie, 1.3.1.

Interne budgettering, 7.2.1.

Intramurale gezondheidszorg, 1.3.3.

Investeringsbudget, 3.3.2.2.

Jaärbudget, 3.3.1.

Joint Consultative Committee, 3.2 .

Kapitaalgoederen, 1.3.1.

Kostengroei, 1.3.1. 
Kostenknikregeling, 6.5.1.

Kostenvergoeding in de vorm van periodieke uitkeringen, 7.2.1.

Krooncommissie, 2.1.3., 4.1.3.

Kruisvereniging, 5.2.

Kwaliteit, 1.3.1.

Läkarstation, 4.2 .

Län, 4.1.3.

Landstingen, 4.1.3.

Landstingförbundet, 4.1.3.

Lange termijn planning, 1.3.3.

Länsdelssjukhus, 4.2 .

Länssjukhus, 4.2 .

Länssjukvård, 4.2 .

LATT, 4.3.1.

LKELP, 4.3.1.

Local authorities, 2.1.3.

Local authority ziekenhuizen, 2.2 .

Local health authorities, 2.2 .

London Weighing, 3.3.2.2.2.

Low morale, 3.4.5.1.

Maatschappelijke dienstverlening, 1.3.3.

Maatschappelijke dienstverlening in Engeland, 2.1.3.

Maatschappelijke gezondheidszorg, 5.2.

Medical and scientific equipment, 3.3.1.

Medical Finance Sub-Committee, 3.3.1.

Medische Staf, 5.2.

Meerjarenbudget, 4.3.2.

Middellange termijnplanning, 1.3.3.

Ministerie van Volksgezondheid en Sociale Zaken, 4.1.3.

Multidistrict area's, 3.2 .

National Insurance Act, 1911, 2.2.

Nationale Raad voor de Arbeidsmarkt, 4.3.1.

NHS-Act, 1946, 2.2.

NHS Reorganization Act, 3.1.

Niveau, 1.3.1.

Normallasarett, 4.2.

Normalsjukhus, 4.2 .

Officers, 3.2 .

Onderfinanciering van de NHS, 2.4.1.

Onderwijsbudget, 3.3.2.2.

Ontwikkelingsproces, 1.2.

Open budget, 1.3.3.

Open zorg, 4.2.

Openbare gezondheidszorg, 5.2.

Operational (operationele) planning, 1.3.3.

Organisatieniveau, 1.3.1.

Organisatiestruktuur, 1.3.1.

Outputfinanciering, 7.2.1.

Overheidsinitiatief, 5.2 .

Overheidsinstelling, 5.2.

Particulier initiatief, 5.2. 
Particulier verzekerden, 5.3.2.

Particuliere artsen, 4.2.

Particuliere instelling, 5.2.

Planning, 1.3.3.

Planning guidelines, 3.3.1.

Political and Economical Planning Group, 2.2.

Porrit-report, 2:4.4.

Principal Finance Officers, 2.1.3.

Proefregio's, 1.1 .

Provinciaal platvorm, 5.3.1.

Provinciale Raden voor de Volksgezondheid, 5.3.1.

Provincies, 5.1.3.

Public Expenditure Survey Committee Report, 2.1.3.

Queens speech, 2.1.3.

Raad voor de Sociale Verzekeringen, 4.1.3.

Rationing health care, 3.4.3.1.

Regio voor gezondheidszorg, 1.3.3.

Regional Health Authorities, 3.2.

Regional Hospital Board, 2.2.

Regional manpower committee, 3.3.1.

Regional officers, 3.2 .

Regionale Instituten voor de Ambulante Geestelijke Gezondheidszorg, 5.3.1.

Regionale Instituten voor de Geestelijke Gezondheidszorg, 5.3.1.

Regionalisatie, voorwoord

Regionsjukvård, 4.2.

Relatieve zorgbehoeften, 3.3.2.2.

Relative needs, 3.3.2.2.

Resource allocation, 7.2.1.

Resource Allocation Working Party, 3.3.2.1.

Restricted area, 2.3.

Revenue Consequence of Capital Schemes, 2.3.

Royal Commission, 2.1.3.

Royal Commission on the NHS, 3.4.4.

RUPRO's, 4.3.1.

Satisfactie, 1.3.1.

Second Green paper on the NHS, 2.4.4.

Sector-administrator, 3.2.1.

Seebohm-report, 2.4.4.

Selectief investeringsbeleid, 5.4.2.1.

Seniorposts, 3.3.1.

Service-Increment for Teaching, 3.3.2.2.2.

Services mainly used by the elderly and physically handicapped, 3.4.1.

Shadow plans, 3.4.1.

Single district area, 3.2 .

Social services, 1.3.3.

Social Styrelsen, 4.1.3.

Social Versamket, 1.3.3.

Stafbestuur, 5.2.

Stop-go-politiek, 2.1.1.

Strategische planning, 1.3.3., 3.3.1.

Styrelsen, 4.1.3.

Supplementary requirements, 2.1.3.

Supply Estimates, 2.1.3. 
Taakstellend budget, 1.3.3.

Tariefstelsel, 7.2.1.

Tariefsysteem, 7.2.1.

Teaching area, 3.2 .

Teaching district, 3.2 .

Teaching hospitals, 2.2 .

Toegankelijkheid, 1.3.1.

Toewijzingskriteria, 2.3 .

Tripartite structure, 2.2., 3.3.

Under-doctored area's, 2.4.3.

Unit-administrator, 3.2.1.

United Kingdom (U.K.), 1.3.3.

Vårdcentral, 4.2.

Variabele budgettering, 7.2.1.

Vaste budgettering, 7.2.1.

Vaststellen, 1.3.3.

Verenigd Koninkrijk (V.K.), 1.3.3.

Vestigingsbeleid, 2.3.

Vice-chairman district medical committees, 3.2.1.

Volksverzekering tegen ziektekosten, 1.1.

Voluntary ziekenhuizen, 2.2.

Voorziening, 1.3.3.

Wachtlijst, 2.4.1.

Werkeenheid, 1.3.3.

White paper, 2.1.3.

White paper NHS reorganized: England, 3:1.

White paper on public expenditure, 2.1.3.

Wijkgezondheidszorg, 1.3.3.

Zeven-kronen-hervorming, 4.2 .

Ziekenfondsen, 5.3.2.

Ziekenfondsgrens, 5.3.2.

Ziekenfondsraad, 5.2.1.

Ziekenhuiscommissie, 5.2.1.

Ziekenhuisplan, 1.1.

Zorgketens, 5.4.4.

Zorgniveau's, 4.2 .

Zweedse Medische Associatie, 4.3.1. 


\section{CURRICULUM VITAE}

1949

1967

1973

$1971-1972$

1972-1973

1973-heden

1973-1974

1974-heden $1977-1980$ geboren te Amsterdam gymnasium B te Amsterdam cum laude doktoraal examen economie, Universiteit van Amsterdam assistent onderzoeker Stichting voor Economisch Onderzoek van de Universiteit van Amsterdam

student assistent macroeconomie Juridische Faculteit van de Rijksuniversiteit Utrecht

deeltijdbaan wetenschappelijk medewerker Instituut voor $Z$ iekenhuiswetenschappen van de Rijksuniversiteit Utrecht

uurdocent economie Hogere Beroeps Opleiding Verpleegkundigen te Leusden

gemeenteraadslid voor de Partij van de Arbeid te Utrecht uurdocent economie Hogere Opleiding van de Hogere School voor Gezondheidszorg te Leusden 